


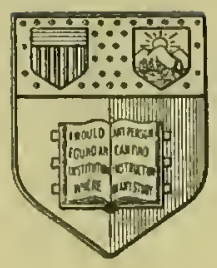

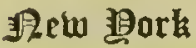

State Callege of Agriculture

At Cormell antibersity

3ltbaca, 2R.

\section{Zibrarp}


SF $65.588^{\text {Cornell University Library }}$

The domestic animals:embracing,

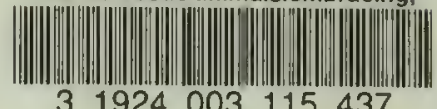

31924003115437

DATE DUE

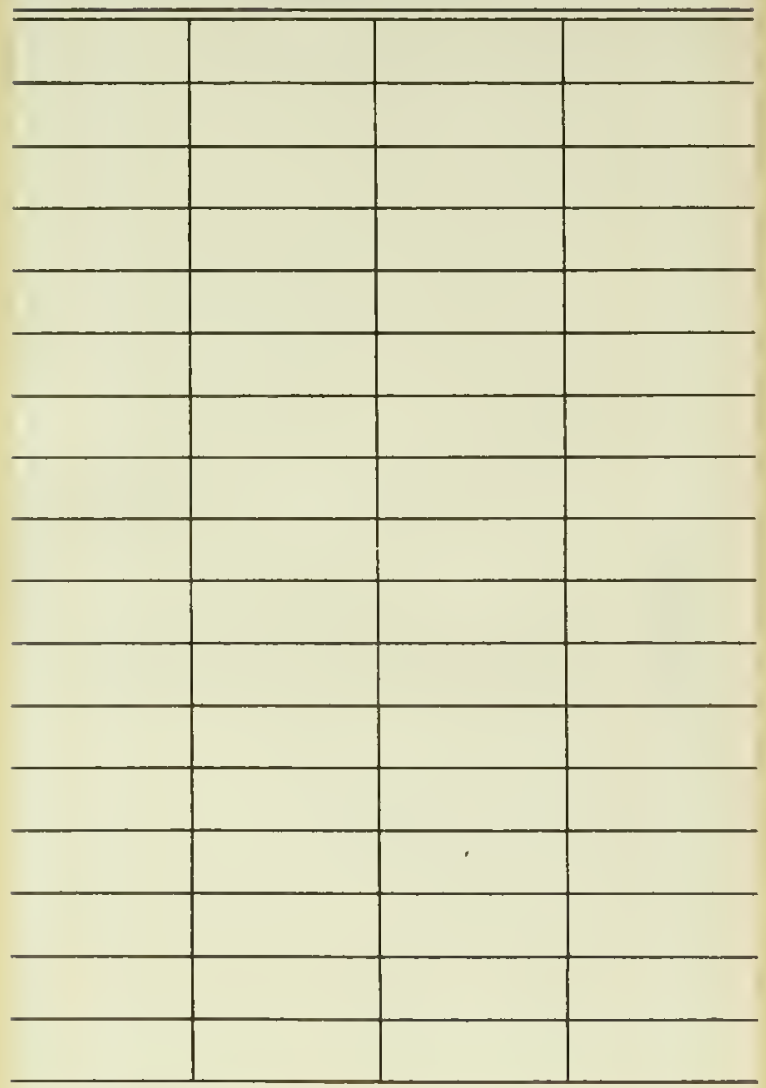

DEMCO $38-297$ 



\section{$\mathrm{TH} \mathrm{E}$}

\section{DOMESTIC ANIMALS:}

EMBRACLNG

1. The IFrme-TO BREED, BREAK, FEED, MANAGE, AND CURE I. Cattle.-TIIE VARIOUS BREEDS, AND IIOW TO MANAGE TIEM. 11. Sheep.-TIIEIR BREEDS, MANAGEMENT, DISEASLS, ETC. IV. 'Tho IIg.-TO BIEED, FEED, CUT UP, AND CURE.

V. Poultry•-TIE IIFFERENT KINDS, $\Lambda$ ND TREATMENT. VI. Bee\%,-TIEIR UABITS, MANAGEMENT, ETC.

FROM THE LATEST AND BEBT AUTHORITIEB.

I L L USTRATED.

HDITH: BY E. G. STOTRKF.

A UBUR N, N. Y .

THE A UBURN PUBLISHING COMPANT. E. G. SPORKE, PUBLISHING AGENT. 
(a

$$
\begin{aligned}
& \text { SF 65 } \\
& \text { SP }
\end{aligned}
$$

Entered according to the Act of Congress, in the year 1859 BY WILLIS W. SITTER,

In the Clerk's Office of the District Court for the Northern District of New York

(a) 26831 


\section{INDEX TO THE DOMESTIC ANIMALS.}

A.

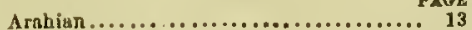

Aidernoy cattie .................... 108

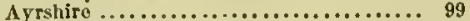

Angus cattie...................... 118

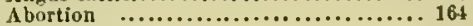

B.

Bacon, to curo.................... 293

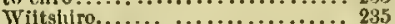

l3arey for the horse.................. 40

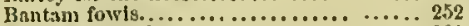

Jees, rinsses of ...................... 251

4 their wonderful instincts........... 282

1. advantnges of keepiag.............. 258

st thelr manngement................ 258

" "

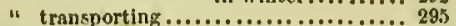

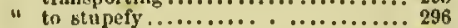

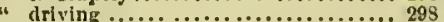

"6 how to fcod..................... 2S4

" fali foeding of.................... 291

" componstion of food for............. 2N5

"s care in swarming............... $2 \$ 6$

". hivos and hoxes for... ......... 292-305

" enemios of ................. 298

Bec, the queen, drono nnd working ... 23i. 232

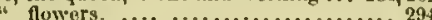

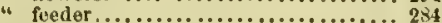

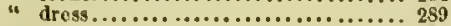

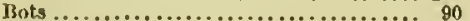

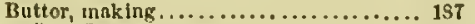

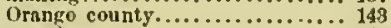

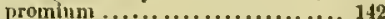

Brecding the horse.................... 19

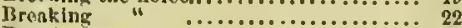

Breeding-mares, care of.............. 21

Backing the horse................. 23

Bitting "

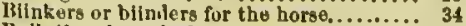

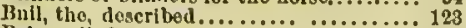

Bakewoll sheep... .................... 174

Berkshire hog..................... 203

\section{c.}

Cleveinnd hay

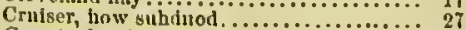

Carrots, for tho hors $0 \ldots \ldots \ldots \ldots \ldots \ldots \ldots \ldots \ldots . . \ldots . \ldots \ldots$

Cungestion. ..........................

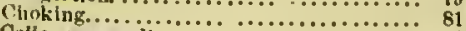

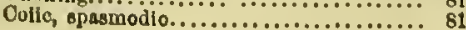

PAER

Catarrh........................ 88

Cheshire cattio.................... 10

Cow, deseription of a good.. .......... 124

" proftes of .................. 152

"s spaying of, its advantnges, otc...... 156

Calves, to rear...................... 125

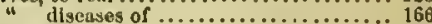

Caiving ........................ 16.9

Cheese, making.................... 147

Churn........................... 189

Cud, loss of...... ............... 1 tit

Cuchin Chinn fowis.................. 246

Cattle, their hreods, otc................ 97

" their valuo................ 97

"t diniry hreeds of................. gT

" Ayrshire.................... 99

" Aldernoy........................ 108

" Forkshiro........................... 105

" Cheshire....................... 10s

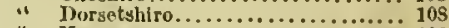

" Kerry ....................... 10s

" Duriaii........................... 111

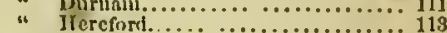

" West lighlind scot................ 114

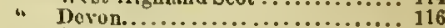

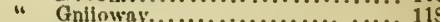

" Anqus.....

" Lelcestershire.................... 107

" broeding..................... 118

" renring....................... 126

" fenting.......................... 126

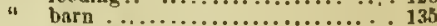

" discrses of eto.................. 162

" to estimate live weight of ......... 241

" choking of..................... 169

" ercenn-pot breod................... 24

Cotswold sheep.......................... 179

Cheviot shoep......................... 179

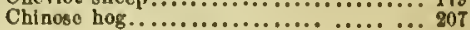

\section{D.}

Dorso:shiro cattio.................. 109

Dairy hreeds of cattio..................

Dairy houso $\ldots \ldots \ldots \ldots \ldots \ldots \ldots \ldots \ldots \ldots \ldots$. 137

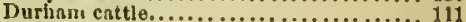

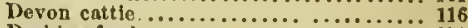

Dorking fowl. ........................ 250

Duck, domestic.... .................. 269

\section{E.}

Fxercise of the horse .............. 48

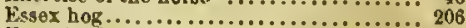

Eggs to ship....................... 27t 
I.

Fat-producing broeds of cattle .......... 108

Food of horses on.

w relative valuo of.................. 40 relative valuo of................... 49

solid, for cnlves................. 128

Feeding cattlo ... .................... 128

Food should he eooked.................. 132

Food, kinds of for eattle............... 132

Fond as affocting mllk................ 136

Founder.......................... 80

Fonndor, chronle................... 86

Felon ........................... 168

Foul in the foot.................... 165

Fowls, Malny ..................... 245

" Cochin Chlna................. 246

Spanish ..................... 247

Polnnd .................... . 248

IIamhurg..................... 249

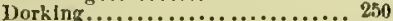

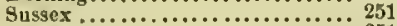

game..................... 251

Bantam.................... 252 " game..................... 253

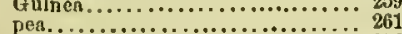

pea..............................

to ceponizo.................. 272

G.

Grooming

Glanders.

Galloygy enttle......

Gloucestershlre hog.................... 205

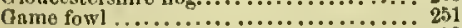

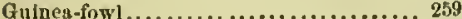

Goose, dornestle.................... 204

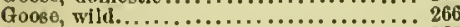

Goose, Canadn....................... 268

\section{I.}

Hams, Westphalia.................. 295

Hams to cure.................... 238

Ilorse, character of. . ................ 11

" breeds of, In the United States...... 11

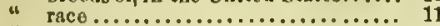

4 Arahian..................... j8

" Canadian....................... 14

* Norman ....................... 14

4 Afurgan...................... 16

" Clevoland bay.................. 17

" dray ....................... 17

" trotting........................... 18

" to hreod....................... I9

" to hresk ..................... 22

" riding tho.................... 28

" taming, the Rarey syatom........ 26-86

" atable, managemont of the.......... 36

Horees, food of. .................... 39

Horses exerclse of .................... 46

Ilorses feet to manngo................. 47

IIorse, to shoe .................... 48

Horse-shoes, different kinds of ........

Ilorse, fallen, to manago .............. 89

" vices and dnngerous habits of .... $59-69$

4 (coundness ar

hls purchase and salo............69-79

4 disenses of ete

". distemper................... 87

4 medleine for..................... 98

ITereford hreed of cattio $\ldots \ldots \ldots \ldots \ldots \ldots \ldots, 118$

Helfor, age of, for hroeding ................ 125

Hoven or " over full" ................ 168

Hives and hoxes for bees $\ldots . . . \ldots \ldots . . . .305$

llog, domestlo....................... 208

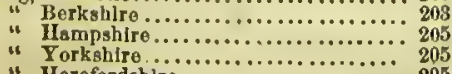

"Herefordshire

200

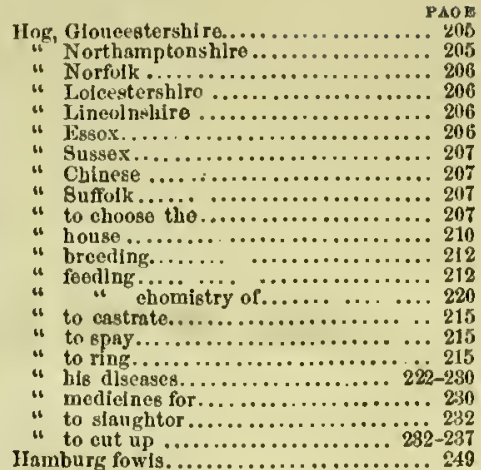

\section{I.}

Inflammatlon.......... 80 " of the jungs.............. 82

". of the hrain............ 85

I.

Kerry cattle...................... 108

L.

I.ficestorshire cattlo............... 107 Lnetometer.......................... 152

Lambs, erre of.................... 1s4

" substitute.................... 186

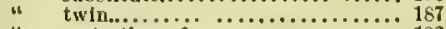

" enstration of . . . . . . . . . . . . . 188

" docking of.................... 190

" spaying of. ...................... 191

Lineolnshire hog .................. 206

1.ieestershire hog.................... 206

II.

Mllking..................... 187

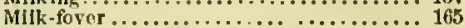

Morino sheep, American............... 171

Merino sheop, Baxon................. 178

Malay fowls..................... 245

N.

Northamptonshiro hog............. 205

Norfolk hog..................... 206

0.

Ox described.................... 124

\section{$\boldsymbol{P}$}

Potatoes for the horbo................. 41

Poll-evil ......................... 88

$\mathrm{Jig}_{\mathrm{g}}$ to cliooso....................... 207

Pork, to curo ..................... $281-298$

Poultry, domestle $\ldots \ldots \ldots \ldots \ldots \ldots \ldots \ldots .245$

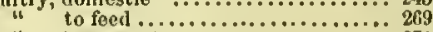

". houses, otc.................. 270

" to eaponlze................... 272

" to ship .................... 276

" Importanco of keeplng......... 245

Its varlotles... ............ 245

Pea-fowl............................. 261

\section{IR.}

Reproductlon applled to cattle......... 125

Rearing calves....................... 126

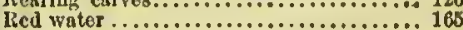


S.

Btable management

Stable, ventilation of tho........... 87

" cleanliness of the.................. 88

"s flnar...................... 88

Shoeing the lierse...................... 48

Shoes, hisw to put on .............. 49

Shoes, different kinds of........... $50-59$

Spavin ........................... 86

Strangles........................ s7

Spaying cews..................... 15

" $i t s$ advantages................ 156

" "how dono.............. 159

". " care after operation........... 161

Stock, number to be kept............. 238

Bpanish fowls..................... 247

Slrenp ............................. 171

" native......................... 171

"American merino................ 171

i. Saxon merlnues................. 173

" Bakewell .................... 174

"south-Down .............. 175

" Cotswold ........................ 179

"Cheviet ...................... 179

" complarntive valuo of different brecds 150

" their general management.......... 1s3
Sheep, summer management ......... PAGB

4 care in hendulng of

192

"shearing........................... 192

"4 winter manngement ef............ 193

winter food of ................. 193

"t mediches for...................... 193

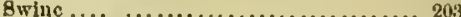

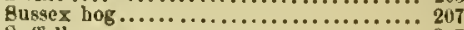

Suffolk................................

\section{T.}

Turnlps, Swedes, fer horses ............ 41

Tnble of medicines for the horso.......... 92

Turkcy, domestic.................... 258

Turkey, wild ..................... 255

W.

Worms in horses................... 81

Wind-galls. ...................... 91

Wheatueal porridge for calves .......... 127

$\boldsymbol{I}$.

Forkshire cattlo ..............

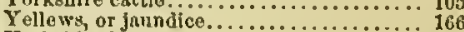

Yerkshire hog..................... 205 



\section{P R E F A C E.}

Tue immense advantages derived from the subjugation to our use of the Domestie Animals are perhaps not fully appreciated. Let any one earefully consider the valuable serviees rendered to eivilized man by the horse, the ox, the eow, the slieep, the pig, the domestie fowl, and the honey bee. Let him take into view the labor they perform, the food and elothing, the comforts and convenienees which they supply, and he will at onee see the importance of the subjects of this manual.

On each of these subjeets carefully arranged treatises are given, showing the best breeds of the several animals, the true methods of breeding, feeding, breaking, working, fattening, ete., the various diseases to which they are subject, and their remedies and treatment. The matter is derived from varied and reliable sourees, from the latest and best European and Ameriean writers, the object being to condense the most useful practical information within the shortest compass, and to so arrange it that any thing sought for could at once be found.

Every owner of a horse, a cow, or a pig, or the keeper of 
bees or of poultry, will find in this work hints and instruction of the most valuable kind, and which, if properly obscrved, will save to him in a single year many times the cost of this volume, in the economy of feeding, and in the increased value to him of the products of the animals kept.

It is intended to be a hand-book, in which can at any time be found the practical directions of men of the largest experience and of the closest observation in its several departments. Such a work it is bcliercd cannot fail of being equally acceptablc and useful to a large class of readers in every section of the eountry. 


\section{THE HORSE:}

HOW TO BREED, BREAK, FERD, AND MANAGE, AND IIOW. TO TREAT HIS DISEASES;

TOGETHER WITI

TIE ART OF TAMING

AQ PRACTKCED BY

W I I, L. I M A N D JOII N S, R A R E Y. 



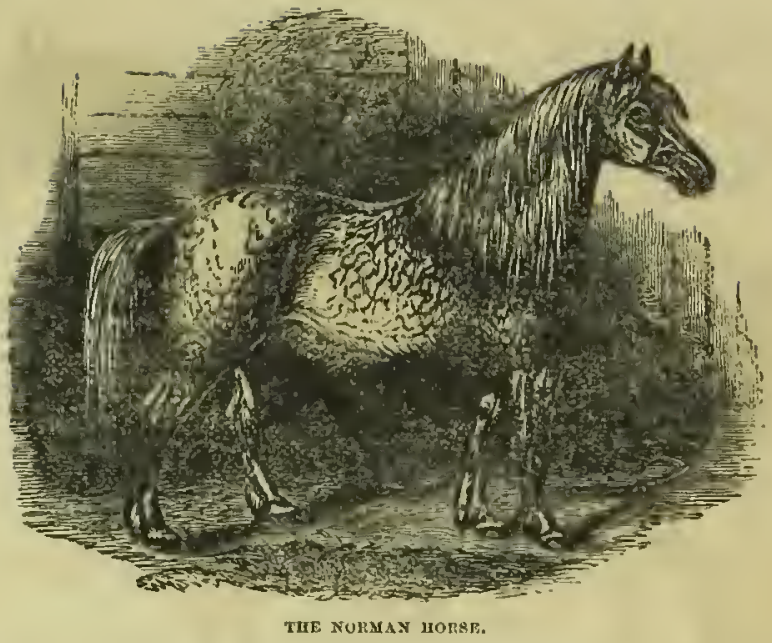

This is the peeuliar lireed of Normanly; which is used so extcnsively throughout the northern half of France for diligenee and post horses, and from the best Irench authorities I could command (I eannot now quote the precise authoritics), I learned that they were produeed by the cross of the Andalusian horse upon the old heavy Norman horse, whose portrait may still be seen as a war-liorse on the painted windows of the cathedral of Rouen, sevcral eenturies old. At the time of the oecupation of the Netherlands by the Spaniards, the Andalusian was the favorite stallion of the north of Europe, and thus a stamp of the true Barb was implanted, which remains to the prescnt day. If you will allow me to digress a moment, I will give you a short deseription of the old Norman draught-horse on which the cross was made. They average full sixteen hands in height, with head short, thick, wide, and hollow between the eyes; jaws heavy ; ears short and pointed well forward; neck very short and thick; mane heavy; shoulder well inclined hackward; back extremely short; rump steep; quarters very broad; chest deep and wide; tendons large; muscles excessively developed; legs very short, particularly from the knee and hock to the fetlock, and thenee to the coronet, which is covered with long hair, hiding half the hoof; much hair on the legs."

- Mr. Youatt, in speaking of the Freneh horses, says: "The lest Freneh horses are bred in Limousin and Normandy. From the former distriet come execllent saddle-horses and hunters; and from the latter a stronger species, for the road, the eavaliy or the carriage. 'The Norman horses are now much crossed by our hunters, and occasionally by the thorongh-bred; and the English roadster and light draught horse has not suffered by a mixture with the Norman."

In his remarks on the coach-horse, Mr. Youatt says: "The Noruandy earriers travel with a tcam of four horses, and from fourteen to twentytwo miles in a day, with a load of ninety lundred weight." 


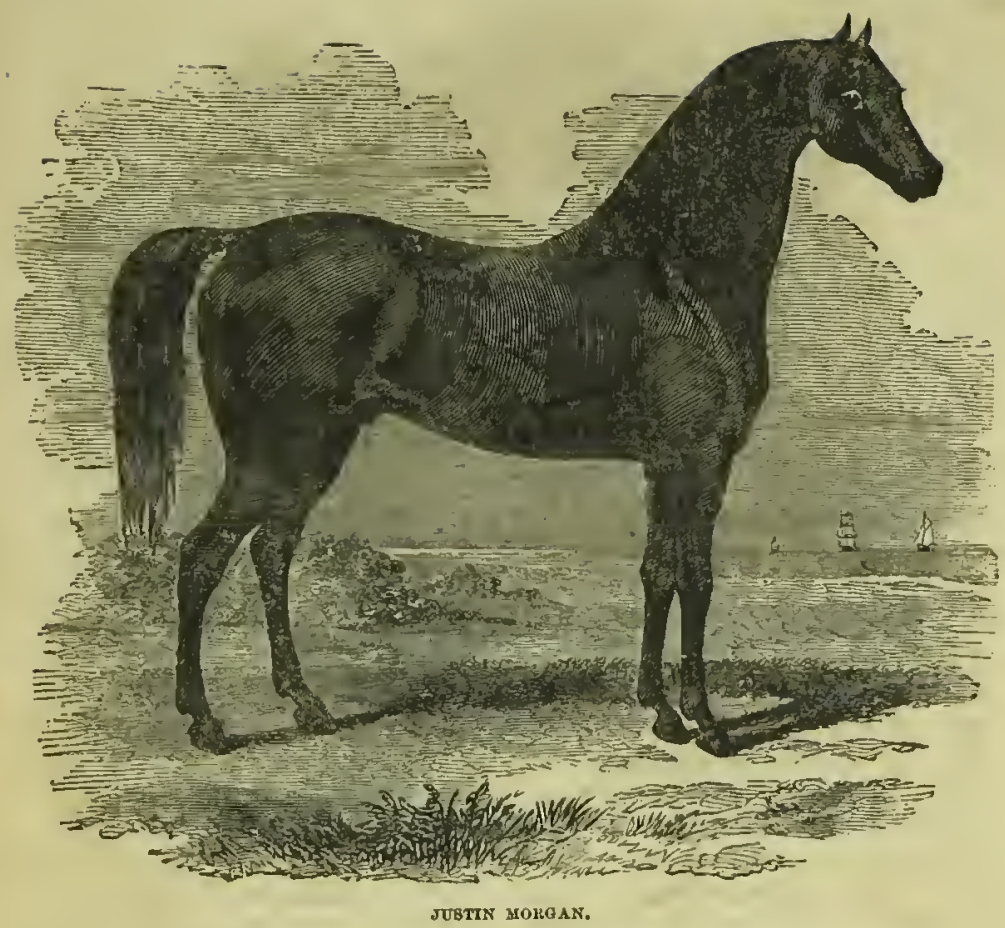

The Comnittee of the N. Y. State Agricultural Society, "on stock owned ont of the state," at the State Fair at Auburn, in 1846, thus spoke of the Morgans:

"Gifford Morgan, a dark chestnut stallion, fourteen hands and three inclies high, aged twenty years, was exlibited by F. A. Weir, of Walpole, N. H. It is claimed on the part of his owner, that this horse possesses tho eelebrated 'Morgan' blood in 'greater purity than any other now living. 'General Gifford,' got by the above-named horse, was exhibitcd by Mr. C. Blodget, of Chelsea, Vt. In lis size, figure, action, and color, he elosely resembles his sire. Both are exceedingly compact horses, deep-ehested and strong-baeked, with fore-legs set wide apart, and carrying their heads ( $v$ iiel are small, with fine, well-set eyes) high and gracefully, without a vearing-rein. 'Their aetion attracted the marked arlmiration of all. This breed are reputed to possess great bottom and hardiness, and every thing abont the two presented, goes to prove that their reputation in this partieular is well founded. For light earriage or buggy horses, it would be difficult to equal them, and if by crossing with prine large mares, of any breed, size could be obtained in the progeny, without losing the fire and action of tho Morgan, the result of the cross would be a earriage of very superior quality. Your eommittee are not aware of the extent or result of such crosses, 
in the region where the Morgans originated. Unless experience has already demonstrated their inutility, we could reeommend to our horsebrecders some well-considered experiments, limited at first, to test the feasibility of engrafting the Morgan characteristics on a larger horse."

The Cleveland Bay.-Tlis horse is thus described by Mr. Youatt:

"The produce of Cleveland mares is a coach-horse of high repute, and likely to possess good action. His points are, substanee well placed, deep and well-proportioned body, strong and elean bone under the knce, open, sound, and tough feet, with fine knee action, lifting his feet high. The full-sized coach-horse is in fact an orergrown hunter.

"The old Cleveland horse is almost extinct, and his place supplied in the manner just described. The Suffolk l'uneh, the product chiefly of Suffolk and some of the neighbouring distriets, is regenerated, but is a different sort of animal to the breed of olden times. He usually varied from fifteen to sixteen hands in lieight, and was of a sorrel color. He was large-lieaded, low-slouldered, broad and low on the withers, deep, and yet round-chested; long in the back, large and strong in the quarters, round in the legs, and strong in the pasterns. He would throw lis whole weight into the eollar, and had sufficient hardihood and strength to stand a long day's work. The pure breed has, however, passed away, and is sueceeded by a cross between the half or three-parts bred Yorkshire with the old Suffolk. He is taller than the former horse, somewhat higher and firmer about the shoulders, with sufficient quiekness of action and honesty to exert himself to the utmost at a dead pull, whilst the proportion of the withers enables him to throw immense weight into the collar. The encouragement given by the Royal Agricultural Society of England for horses of this class has been the cause of considcrable increase in their numbers."

Cleveland Bays have been introduced into this country, and lave spread eonsiderably. They are very large horses; and, for their size, are symmetrieal in form, and fair in aetion. The eross with our common mares produees an exeellent farm horse, though said to be of sullen temper.

The Drny-Ilorse. - Of the heavy black dray-horses, but few have been imported into this country, and they do not seem likely to become favorites here. Mr. Youatt says of them :

"The heavy black horse is the last variety it may be neeessary to notice. It is bred ehiefly in the midland counties, from Lineohshire to Staffordshire. Many are bought up by the Surrcy and Berkshire farmers at two years old,-and being worked moderately until they are four, earning their keep all the while, they are then sent to the London market, and sold at a profit of ten or twelve per eent.

It would not answer the breeder's purpose to keep them until they are fit for town work. Ir has plenty of fillies and mares on his firm for every purpose that he can require; lie therefore sells them to a persou nearer the metropolis, by whom they are gradually trained and prepared. The traveler has probably wondered to see four of these enormous animals in a line before a plow, on no very heavy soil, and where two lightiter horses would have been quite suffieient. The faruser is training them for their future destiny; and he docs riglit in 
not requiring the exertion of all their strength, for their bones are not yet perfectly forned, nor their joints knit; and were he to urge them too severely, he wonld probably injure and deform them. By the genthe and constant exereise of the plow, he is preparing them for that continued and equable pull at the eollar, which is afterward so neecssary. These horses are adapted more for parade and show, and to gratify the ambition which one brewer has to outvie his neighbor, than for any peculiar utility. They are eertainly noble-looking animals, with their round, fat carcases, and their sleek eoats, and the evident pride which they take in themselves; but they eat a great deal of hay and eorn, and at hard and long-eontinued work they would be completely bcaten by a team of aetive muscular horses an ineh and a half lower.

The only plea whieh ean be urged in their favor, beside their fine appearanee, is, that as shaft-horses over the badly-paved streets of the metropolis, and with the immense loads they often have behind them, great bulk and weight are neeessary to stand the unavoidable shaking and battering. Weight must be opposed to weight, or the horse would sometimes be quite thrown off his legs. A large heavy horse must be in the shafts, and then little ones before him would not look well.

The Trotting-IIorse, - The relative merits of the English and Ameriean trotting-horse, have been the subjects of earefnl diseussion by competent judges. The New York Spirit of the Times, one of the best authorities on this subjeet, thus canvasses the matter:

"Nimrod, in admitting the superiority of our trotting-horses to the 'Englisli,' claims that the English approaeh very near to the Amerieans. Possibly the eharacteristic national vanity would not allow him to make a further concession. But there is no eomparison whatever between the trotting horses of the two eountries. Mr. Wheelan, who took Rattler to England, last season, and doubly distanced, with ease, every horse that started against him, as the record shows, informs us that there are twenty or more joadsters in eommon use in this city, that would compete sueessfully with the fastest trotters on the English turf. They neither understand the art of training, driving, nor riding them. For example: some few years sinee, Alcxander was purehased by Messrs. C. and B. of this city, for a friend or aequaintanee, in England Alexander was a well known roadster here, and was purcliased to order at a low rate. The horse was sent out and trials made of him; but so unsueeessful were they, that the English importers considered him an imposition. 'Thus the matter stood for a year or more. When Wheelan arrired in England, he recognized the horse and learned the particulars of his purchise, and subsequent trials there. By his advice the horse was nominated in a stake, at Maneliester we believe, with four or five of the best trotters in England, Wheelan agreeing to train and ride him. When the horses eame upon the ground, the odds were four and five to one, against Alexander, who won by nearly a quarter of a mile. Wheelan says he took the traek at the start, and widened the gap at his ease-that near the finish, being surprised that no horse was near him, as his own had not yet made a stroke, he got frightened, thinking some one inight outbrush him,-that he put Alexander up to his work, and finally won by an immense way, no horse, 
literally, getting to the head of the quarter stretch, as he came out at the winning stand! The importers of Alexander, at any rate, were so delighted at his performance, that they presented Wheclan with a magnificent timing-watch, and otlier valuable presents, and sent Messrs. C. and B. a superb service of plate, which may, at any time, be seen at their establishment, in Maiden Lane."

This differenee between English and American trotters is clearly attributable to superior training and jockeying. We have in this country hundreds of Rareys, who can teach not only the nobles of the realm but the cominon jockeys also, the mysterious arts of horse-training and managing, although they may not now be able to command for their services quite the compensation which that gentleman received.

BREEIDING.-Breeders of all kinds of animals are unanimous in their opinions that it is necessary to have distinct varieties, usually distinguished as thorough-bred, for the propagation of the species, whether it be determined to earry on the unblemished pedigree, or to cross with other breeds. The ligh valne set upon the short-horued cattle, is estimated principally by the purity of the blood; and the true Southdown or Lcicester sheep by a similar eriterion.

It is a general observation with those who have devoted attention to the subject, that horses and mares require much time after they have been trained, before they distinguish thenselves as the progenitors of first-rate stock. This affords another argument in favor of early training. Both with inares and stallions their best foals have often not come forth till they were advaneed in year's. According to the presumed age of the Godolphin Arabian, he was thirteen years oll when he became the sire of Regulus. Paynator and Whalebone were each of them twenty years old when their sons, Dr. Syutax and Sir Hercules, were foaled. Potoooooooo, Sultan, Langar, and Venison, were each of them sixteen years old when they became the sires respeetively of Waxy, Bay Middleton, Epirus and Kingston. Melbourne was fifteen when he begot West Australian; Hap-hazard fourteen when he was the sire of Fillo da Puta. Orville was the same age when he was the sire of Ebor, and twenty when he begot the still more celebrated Enilius; and an infinity of similar examples may be addel. This property applies more generally to stallions than to mares: for it is sometimes apparent, thatiheir first foals are rastly superior to their subsequent prodnce. This was the case in olden times with the dims of Mark Antony, Conductor, Pyrrhus, and Pantaloon; and more recently with Sultan, Touchstone, Sir Hercules, and Fillio da Puta. Whether the subsequent ehange of partners has any prejudicial eflicet on the future progeny, is a subject worthy the nost serupulous attention of beceders. The ease of Penclope is in faror of the assumption; for the superiority of her first seven foals by Waxy, over the others by different horses, is a fact which cannot be disputed. It is eurious to remark, that when a thorough-bred mare has once had foals to common horses, no subsequent foals which she may have had by thorough-bred horses have ever evinced any pretensions to racing qualities. There may be an exception; but I believe I am eorrect in statiug that there is not. It is laid down as a principle, "That when a pure animal, of any breed, has onee been pregnant to one of a different 
breed, she is herself a cross ever after; the purity of her blood having becn lost in cousequence of this connection." This will no doubt be received by many persons as an abstruse hypothesis, but there are unequivocal incidents in favor of it; and that valuable monitor, past expcrience, must be received as a more eonvineing argument than the opinion of inclivichals, on subjects which are hidden from our understanding by the inpenctrable veil which, on many occasions, enshrouds the secret mysteries of nature. There are events on record which prove this faculty, although they do not enlighten us as to the physical influences which control it. Sir Gore Onsely, when in India, purchased an Arabian mare, which during several seasons would not breed, and, in consequence, an intercourse with a zebra was resorted to; she produceu an animal striped like its male parent. The first object being accomplished, that of cansing her to breed, a thorongh-bred horse was selected, but the produce was striped. The following year another horse was chosen, yet the stripes, although less distinet, appeared on the foal. Mr. Blaine relates that a chestnut mare also gave birth to a foal by a quagga, and that the mare was afterward bred from by an Arabian horse, but that the progeny exhibited a very striking resemblance to the quagga.

The progeny will, as a rule, inherit the general or mingled qualities of the parents. There is scarcely a discase by which either of them is affected, that the foal does not often inherit or show a predisposition to it. Even the consequences of ill-usage or hard work will descend to the progeny. There las been proof upon proof that blindness, roaring, thick wind, broken wind, spavins, curbs, ringbones, and founder, have been bequeathed to their offispring both by the sire and the dam.

Peculiarity of forn and constitution will also be inherited. This is a most important but neglected consideration; for, however desirable or even perfect may have been the conformation of the sire, every good point may be nentralized or destroyed by the defective structure of the mare. The essential points should be good in both parents, or some minor defect in either be met, and got rid of by excellence in that particnlar point in the other. The unskillful or careless breeder, too often so badly pairs the animals that the good points of each are almost lost, the defects of both increased, and the produce is far inferior to both sire and dam.

The mare is sometimes put to the horse at too early an age; or, what is of more frequent occurrence, the mare is ineapable from old age. The owner is unwilling to destroy lier, and determines that she shall pay for her keeping by bearing him a foal. What is the consequence? The foal exhibits an unkindness of growth, a corresponding weakness, and there is scarcely an organ that possesses its natural and proper strength.

That the constitution and power of endurance of the horse are in a great ineasure inherited, no sporting man ever doubted. The qualities of the sire or the dam deseend from generation to generation, and the exeellenees or defects of certain horses are often traced, and justly so, to some peculiarity in a far-distant ancestor.

It may, perhaps, be justly affirmed, that there is more difficulty in selecting a good mare to breed from than a good horse, because she 
should possess somewhat opposite qualities. Her eareass should be long, in order to give room for the growth of the foetus; and yet with this there should be compactness of form and shortness of leg. What ean they expect whose practice it is to purehase worn-ont, spavined, foundered inares, about whom they faney there have been some good points, and send them far into the country to breed from, and, with all their variety of shape, to be covered by the same horse? In a lottery like this there may be now and then a prize, but thero must be many blanks.

As to the shape of the stallion, little, satisfactory, can be said. It inust depend on that of the mare, and the kind of horse wished to be bred ; but if there is one point absolutely essential, it is "compactness" -as much goodness and strength as possible condensed into a little space.

Next to compaetness, the inclination of the shoulder will be regarded. A huge stallion, with upright shoulders, never got a capital hunter or hackney. From him the breeder ean obtain nothing but a eart or dray horse, and that perhaps spoiled by the opposite form of the mare. On the otlier hand, an upright shoulder is desirable, if not absolutely necessary, when a mere slow draught-liorse is required.

From the time of eovering, to within a few days of the expeeted period of foaling, the eart-mare may be kept at moderate labor, not only without injury, but with decided advantage. It will then be prudent to release her from work, and keep her near home, and under the frequent inspection of some careful person.

When nearly half the time of pregnaney has elapsed, the mare should have a little better food. Slie shonld be allowed one or two feeds of grain in the day. This is abont the period when they are aceustomed to slink their foals, or when abortion oceurs; the eye of the owner should, therefore, be frequently upon them. Good feeding and moderato exereise will be the best preventives of this mishap. The mare that bas onee aborted is ljable to arepetition of the aecident, and therefore should never be suffered to be with other mares between the fourth and fifth months; for such is the power of inagination or of sympathy in the mare, that if one suffers abortion, others in the same pasture will too often share the same fate. Farmers wasl, and paint, and tar their stables, to prevent some supposed infection-the infection lies in the imagination.

The thorough-bred mare--the stock being intended for sporting purposes-should be kept quiet, and apart from other horses, after the first four or five months. When the period of parturition is drawing near, she should be watched and shut up during the night in a safe yard or loose box.

If the mare, whether of the pure or common breed, be thus taken eare of, and be in good health while in foal, little danger will attend the act of parturition. If there is false presentation of the foetus, or difficulty in produeing it, it will be better to have recourse to a wellinformed practitioner, than to injure the mother by the violent and injurious attempts that are often made to relieve ber.

The parturition being over, the mare should be turned into some 
well-sheltered pasture, with a hovel or shed to run into when she pleases; and if she has foaled early, and grass is seanty, she shonld have a couple of feeds of grain daily. The breeder may depend upon it, that nothing is gained by starving the mother and stinting the foal at this time. It is the nost important period of the life of the horse; and if, from false economy, his growth is arrested, his puny form and want of enduranee will ever afterward testify the error that has been eommitted. The grain should be given in a trough on the ground, that the foal inay partake of it with the mother. IThen the new grass is plentiful, the quantity of corn may gradually be diminished,

The mare will usnally be found again at heat at or before the expiration of a month from the time of foaling, when, if she is prineipally kept for breeding purposes, she may be put again to the horse. $\Delta \mathrm{t}$ the same time, also, if she is used for agrieultural purposes, she may go again to work. The foal is at first shut in the stable during the hours of work; but as soon as it aequires snffieient strength to toddle after the mare, and espeeially when slie is at slow work, it will be better for the foal and the dam that they should be together. The work will eontribute to the health of the inother; the foal will more frequently draw the milk, and thrive better, and will be harly and traetable, and gradually familiarized with the objects among which it is afterward to live. While the mother, however, is thus worked, she and the foal should be well fed; and two feeds of eorn, at least, shonld be added to the green food whieh they get when turned out after their work, and at night.

In five or six months, aecording to the growth of the foal, it may be weaned. It should then be housed for three weeks or a month, or turned into some distant riek-yard. There ean be no better place for the foal than the latter, as affording, and that without trouble, both food and shelter. The mother should be put to harder work, and have drier food. One or two urine-balls, or a physic-ball, will be useful, if the milk should be troublesome or she shonld pine after her foal.

There is no prineiple of greater importance than the liberal feeding of the foal during the whole of his growth, and at this time in particular. Bruised oats and bran should form a eonsiderable part of his daily provender. The farmer may be assured that the money is well laid out which is expended on the liberal nourishment of the growing eolt; yet, while he is well fed, he should not be rendered delieate by exeess of eare.

A raeing colt is often stabled; but one that is destined to be a hunter, a hackney, or an agricultural horse, shonld have a square riek, nnder the leeward side of which he may shelter himself; or a hovel, into whieh he may run at night, and out of the rain.

BREAKING, - Tlic proeess of breaking-in should commenee from the the very period of weaning. 'The foal should be daily handled, partially dressed, aeeustomed to the halter when led about, and even tied up. The traetability, and good temper, and value of the horse, depend a great deal more upon this than breeders are aware.

Every thing shonld be done, as mueh as nossible, by the man who feeds the colt, and whose management of him should be always kind and gentle. There is no fault for which a breeder should so invariably 
discharge his scrvant as cruelty, or even harshness, toward the rising stock; for the principle on which their after uscfulncss is founded, is early attach ngent to, and confidence in man, and obcdiencc, inplicit obedicnce, resulting principally from this.

$\Lambda$ fter the sccond winter the work of breaking-in may commence in good earnest. The colt may bc bitted, and a bit sclcctcd that will not hourt his mouth, and mucl smaller than those in common use. With this he may be suffered to amuse himself, and to play, and to champ it for an hour, on a fcw successivc days.

Breaking in Harness.-Having become a little tractablc, portions of the harncss unay be put upon hin, concluding with the blind winkers; and, a few days afterward, he may go into the team. It would be better if there could be one horse before and one behind him, besides the sliaft horse. There should at first be the mere empty wagon. Nothing should be done to him, except that he should have an occasional pat or kind word. The other horses will kcep him moving, and in his placc; and no great time will pass, sometimes not even the first day, before he will begin to pull with the rest. The load nay then be gradually increascd.

Riling.-The agricultural horse is sometimes wanted to ride as well as to draw. Let his first lesson be given when he is in the tcam. Let his fceder, if possible, bc first put upon him. He will be too much hampercd by his harncss, and by the other horses, to make much resistance; and, in the majority of cases, will quietly and at once submit. We need not to repcat, that no whip or spur should be used in giving the first lessons in riding.

Backing.- When he begins a little to understand his business, backing-the most difficult part of lis work-may be taught him; first to back wcll without any thing bchind him, and then with a light cart, and aftcrward with some serious load-always taking the greatest care not seriously to hurt his nouth. If the first lcsson causes much sorcncss of the gums, the colt will not readily submit to a sccond. If he has becn previously rendered tractable by kind usage, time and paticnce will do crery thing that can be wished. Some carters arc in the habit of blinding the colt when tcaching hin to back. 'This may be necessary with a restive and obstinate one, but should be used only as a last resort.

Obedience.-The colt having becn thus partially broken-in, the neccssity of implicit obcdience must be taught him, and that not by severity, but by firmucss and stcadincss. The voice will go a grcat way, but the whip or the spur is sometines indispensable - not so severely applicd as to cxcite the animal to resistance, but to convince him that we have the power to cnforcc subinission. Few, it may alınost be said, no liorses, arc naturally vicious. It is cruel usage which has first provoked rcsistance. That resistance has been followed by greater sevcrity, and the stubbornness of the animal has incrcascd. Opcn warfare lias ensued, in which the man has scldom gained advantagc, and the horse lias been frequently rendered unserviceable. Corrcction may, or must bc used, to enforce implicit obcdience after the education has procecded to a certain extent, but the early lessons should be inculcatcd with kindncss 
alone. Young eolts are sometimes very perverse. Many days will oeeasionally pass before they will permit the bridle to be put on, or the saddle to be worn; and one act of harshness will double or treble this time; patience and kindness, lowever, will always prevail. On some morning, when he is in a better humor than usual, the bridle may be put on, or the saddle may be worn; and, this compliance being followed by kindness and soothing on the part of the breaker, and no ineonvenienee or pain being suffered by the animal, all resistanee will be at an end.

The same prineiples will apply to the breaking-in of the horso for the road or the ehase. The handling, and some portion of instruetion, should eommenee from the time of weaning. 'The future tractability of the horse will mueh depend on this. At two years and a half, or three years, the regular proeess of breaking-in should eommenee. If it is delayed until the animal is four years old, his strength and obstinacy will be more diffieult to overeome. The plan usually pursued by the breaker eannot perhaps be much improved, exeept that there should be much more kindness and patienee, and far less harshness and eruelty, than these persons are aceustomed to exhibit, and a great deal more attention to the form and natural aetion of the horse. A headstall is put on the colt, and a eavesson (or apparatus to eonfine and pinch tho nose) aftixed to it, with long reins. He is first aceustomed to the rein, then led round a ring on soft ground, and at length mounted and taught his paees. Next to preserving the temper and doeility of the horse, there is nothing of so much importanee as to teach him every paee, and every part of his duty, distinetly and thoroughly. Each must constitute a separate and sometimes long-eontinued lesson, and that taught by a man who will never suffer his passion to get the better of his diseretion.

After the eavesson has been attached to the headstall, and the long reins put on, the eolt should bo quietly led about by the breaker-a steady boy following behind, by oeeasional threatening with the whip, but never by an aetual blow, to keep him moving. When the animal follows readily and quietly, he may be taken to the ring, and walked round, right and left, in a very small eirele. Care should be taken to teach him this pace thoroughly, never suffering him to break into a trot. The boy with his whip may here again be neeessary, but not a single blow should actually fall.

Bocoming tolerably perfeet in the walk, he should be quiekened to a trot, and kept steadily at it; the whip of the boy, if needful, urging him on, and the eavesson restraining him. These lessons should bo short. The paee should be kept perfeet, and distinet in eaeh; and doeility and improvement rewarded with frequent earesses, and handfuls of eorn. The length of the rein may now be gradually inereased, and the paee quiekened, and the time extended, until the animal beeomes tractablo in these his first lessons, toward the conclusion of which, erupper-straps, or something similar, may be attached to the elothing. These, playing about the sides and flanks, aceustom him to the flapping of the eoat of the rider. The annoyanee which they oceasion will pass over in a day or two; for when the animal finds that no harm eomes to him, he will ceaso to rogard them. 
Bitting.-Next cones the bitting. The bits should be large and smooth, and the reins buckled to a ring on either side of the pad. There are many curious and expensive machines for this purpose, but the simple rein will be quite sufficient. It sloould at first be slack, and then very gradually tiglitened. This will prepare for' the more perfect Inamel in which the head will be afterward got into its proper position, when the colt is accustomed to the saddle. Occasionally the brcaker should stand in front of the colt, and take hold of eacli side rein near to the mouth, and press upon it, and thus begin to teach him to stop and to back on the pressure of the rein, rewarding every act of docility, and not being too eager to punish occasional carelessness or waywardness.

Slyyillg.-The colt may now be taken into the road or strect, to be gradually accustomed to the objects among which his services will be required. IIcre, from fear or play fulness, a considerable degree of starting and shying may be exhibited. As little notice as possible shonld be taken of it. The same or a similar object should be soon passed again, but at a greater distance. If the colt still shies, let the distance be still farther increased until he takes no notice of the object. 'Then he may be gradually brought nearer to it, and this will be usually effected without the slightest difficulty: whereas, had there been an attempt to force him close to it in the first instance, the remembrance of the contest would have been associated with every appearance of the object, and the habit of shying would have been established.

Use of the Whip.-Hitherto, with a cool and patient breaker, the whip may have been shown, but will scarcely liave been used; the colt must now, however, be accustomed to this necessary instrument of authority. Let the breaker walk by the side of the animal, and throw his right arm over his back, holding the reins in his left, occasionally quickening his pace, and at the moment of doing this, tapping the horse with the whip in lis right hand, and at first very gently. The tap of the whip and the quickening of the pace will soon becone associated in the mind of the animal. If necessary, these reminders may gradually fall a little heavier, and the feeling of pain be the monitor of the necessity of increased excrtion. The lessons of rcining-iu and stopping, and backing on the pressure of the bit, may continue to be practiced at the same time.

lise to the Siddle.-He may now be taught to bear the saddle. Some little caution will be necessary at the first putting of it on. The breaker sloonld stand at the head of the eolt, patting him and engaging his attention, while one assistant on the offside gently places the saddle on the back of the animal, and another on the near sicle slowly tightens the girths. If he submits quietly to this, as he generally will when the previous process of breaking-in has been properly conlucted, the ceremony of monnting may be attempted on the following or on the third day. The breaker will need two assistants in order to accomplislı this. He will remain at the head of the colt, patting and making muclı of him. The rider will put his foot into the stirrup and bear a little weight upon it, while the man on the off side presses equally on the other stirrup-leather; and according to the docility of the animal, he should 
gradually inerease the weight until he balanees himself on the stirrup. If the eolt is uneasy or fearful, he should be spoken kindly to and patted, or a inouthful of grain be given to him; but if he offers serious resistanee, the lessons inust terminate for that day. He may probably be in better humor on the morrow.

When the rider has balaneed himself for a minute or two, he may gently throw his leg over and quictly seat himself in the saddle. The breaker will then lead the aninal round the ring, the rider sitting perfeetly still. After a few minutes he will take the reins and handle them as gently as possible, and guide the horse by the pressurc of them, patting him frequently, and espeeially when he thinks of dismounting; and, after having dismounted, offering him a little grain or green feed. The use of the rein in cheeking him, and of the pressure of the leg and the toneh of the heel in quiekening his paee, will soon be taught, and his edueation will be nearly eompleted.

Kindness united with Firmless. - The horse having thus far submitted himself to the breaker, these pattings and rewards must be gradually diminished, and implieit obedience mildly but firmly enforeed. Severity will not often be neeessary. In the great majority of eases it will be altogether unealled for: but should the animal in a moment of waywardness dispute the eommand of the breaker, he must at onee bo taught that lie is the slave of man, and that we have the power, by other means than those of kindıess, to bend lim to our will. The edueation of the horse slould be that of the elild. Pleasure is as mueh as possible assoeiated with the early lessons, but firmness, or if need be, eocreion, must establish the habit of obedicnee. Tyranny and cruelty will more speedily in the horse than even in the ehild, provoke the wish to disobey and, on every pratetieable oeension, the resistanee to eommand. The restive and vieious horse is, in ninety-nine eases out of a hundred, made so by ill-usage and not by nature. None but those who will take the trouble to make the cxperiment are aware how absolute a eommand the due admixture of firmuess and kindness will soon give ns over any horse.

\section{THE ART OF HORSE-TAMING, AS PRACTICED BY WILLIAM AND JOIN S. RAREY.}

The great sueeess which has attended the system of training horses, as praetieed by the Rarey brothers, induees us to publish their system; and to illustrate it with al propriate engravings.* Their sneeess is eertainly wonderful. The system whieh they follow is, at once hmmane, rational and philosopliceal ; and we earnestly eommend its adoption to all who manage horses not only, but all the other domestie animals.

As evidenee of Mr. Rarey's sueess in England, we eopy the following instanees from the London Review.

* For the illustrations of the "Rarey systom," wo are under obligations to the Rural New-Yorker, and which it gives us pleasure to commend to the attention of our readors, as one of the most valuablo family and agricultural journals published in this country. It has a wido circulation and well deserves it. 
"Cruiser has been vicious from a foal, always troublesome to handle (we are using his owner's language), and showing temper on every opportunity. He would kneel in the strect, and tear the gronnd with his teeth in his paroxysms of rage.- He would lean against the wall of his box, and kiek and seream for ten minutes together; and he was returned from stables in which he had been placed, beeause his savage propensities rendered the eare of him too dangerous an office for any man. For days, he wonld allow no one to enter his box; and on onc oceasion, tore an iron bar, one inch thick, in two with his tecth. Such an animal was not a very pronnising subject to operate upon; but Mr. Rarey undertook his eure. He first subjugated a two-year-old filley perfeetly unbroken, in half an hour-riding her-opening an umbrella, beating a drum upon her, \&e. He then took Cruiser in hand, and, says I Lord Dorehester, 'in three hours, Mr. Rarey and myself mounted him.' He had not been ridden for nearly three years, and was so vicious that it was impossible eren to dress him; and it was neeessary to keep him muzzled constantly. The following morning $\mathrm{Mr}$. Rarey led him behind an open earriage, on his way to London.'

Twiee the ereature tlew at the tamer with a fieree ery, but he kept out of his reach behind a half-door; at last he grew a little kinder, and Mr. Rarey sueeeded in tying his head to the rack. This sense of restraint, which he had not known for three years, maddened the horse, the blood-ressels of the head dilated, and his frenzy for nearly twenty minutes was such, that Lord Dorehester begged Mr. Rarey not to peril his life, and to think no more of the $£ 100$ bond, which he had given, to return him enred in three months. However, Ameriea was not daunted; and when the horse was slightly exhansted, he made his first effort, and by the end of three hours the evil spirit seemed to have departed. On the Monday following, Mr. Rarey opened his sehool. The "ineurably savage" horse was there, and was gentle as a dove, before an audienee of full three hundred; all of whom had heard of his vicious propensities. You could lave heard a pin drop, when the American horsetamer asked his four-legged pupil to shake hands with him, at the termination of a lecture, listened to with intense interest, by an exalted and delighted assembly of the noblest and fairest in the land. The TVednesday after $\mathrm{Mr}$. Rarey rode the horse abont London.

PRINCIPLES OF TIIE RIREY NISTE.I.- "First-That the horse is so constituted by nature that he will not offer resistance to any demand made of him which he fully comprehends, if inade in a way consistent with the laws of his nature. Sccond-That he has no consciousness of his strength beyond his experienee, and ean be handled aecording to enr will withont foree. Third-That we ean, in eomplianee with the laws of his nature, by which he examines all things new to him, take any object, however friylitful, around, over, or on him, that does not infliet pain, without eausing him to fear."

The affectionate enthusiasm with which the horse is spoken of by $\mathrm{Mr}$. Rarey in the paragraph amexed, eopied from his work, would also seem to indieate that any thing but harsh means are used in his subjection. Mr. Rarcy says :

"The horse, aceording to the best accounts we ean gather, has been 


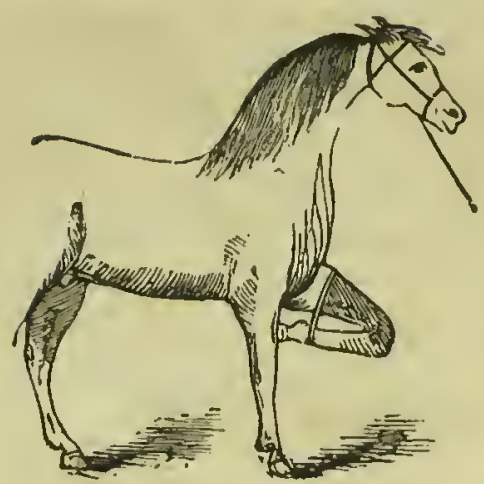

F1G. 1. FIRst posttion.

the constant servant of man for nearly four thousand years, ever rewarding him with his labor, and adding to his eomfort in proportion to his skill and manner of using him; but being to those who govern him by brute foree, and know nothing of the beauty and delight to be gained from the eultivation of his finer-nature, a fretful, vieious, and often dangerous servant; while to the Arab, whose horse is the pride of his life, and who governs him by the law of kindness, we find him to be quite a different animal. The manner in whieh he is treated from a foal gives him an affeetion and attaelment for his master not known in any other eountry. The $\triangle \mathrm{rab}$ and his ehildren, the mare and her foal, inhabit the tent together; and, although the eolt and the mare's neek are often pillows for the ehildren to roll upon, no aeeident ever oeeurs, the mare being as eareful of the ehildren as of the eolt. Sueh is the mutual attaehment between the horse and his master, that he will leave his eompanions at his master's eall, ever glad to obey his voiec. And when the Arab falls from his horse, and is unable to rise again, he will stand by him and neigl for assistanee; and if he lies down to sleep, as fatigue sometimes eompels him to do in the midst of the desert, his faithful steed will wateh over him, and neigh to arouse him if man .or beast approaelies. The Arabs frequently teaeh their horses seeret signs or signals, whieh they make use of on urgent oeensions to eall forth their ntmost exertions."

Mr. Rarey plaees mueh stress upon the kindly tones of the human voiee, manner of speaking, the words used, and finishes his philosophizing upon the subjeet by detailing a short sketeh of an "Arab and his steed," in whieh lie endeavors to show the entire eomprehension possessed by the horse of the language addressed to him. We quote it entire: "A Bedouin named Jabal possessed a mare of great eelebrity. Hassan Pasha, then governor of Damaseus, wished to buy the animal, and repeatedly macle the owner the most liberal offers, whieh Jabal steadily refused. 'The l'asha then had reeourse to threats, but with no better suceess. At length, one Gafar, a Bedouin of another tribe, presented himself to the Pasha, aud asked him what he would give the man who should make him master of Jabal's mare. 'I will fill his horse's 


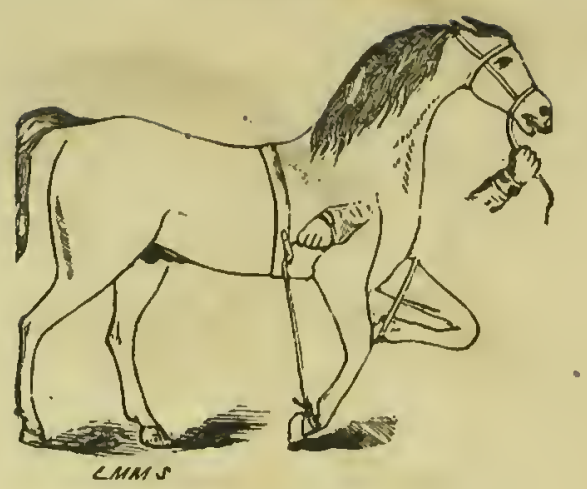

Fra. 2. TEAOHING TEE RORSE TO KRREL.

nose-bag with gold,' rcplied Hassan. The result of this interview having gone abroad, Jabal became more watchful than cver, and always secured his mare at night with an iron chain, one erd of which was fastened to his hind fetlock, whilst the other, after pissing through the tcnt-cloth, was attached to a picket driven in the giound under the felt that served himself and his wife for a bed. But one midnight Gafar crept silently into the tent, and succecded in loosening the chain. Just before starting off with his prize, he eaught up Jabal's lance, and, poking him with the butt end, cried out, "I am Gatar'; I have stolen your noble mare, and will give you notice in tinc.' This warning was in accordance with the customs of the desert, for to rob a hostile tribe is considered an honorable exploit, and the man who accomplishes it is desirous of all the glory that may flow fiom the deed. Poor Jabal, when he heard the words, rusbed out of the tent, and gave the alarm; then, mounting his brother's mare, accompanied by some of his tribc, he pursued the robber for four hours. The biother's mare was of the same stock as Jabal's, but was not equal to her; nevertlieless, he outstripped those of all the other pursuers, and was even on the point of overtaking the robber, when Jabal shouted to him, 'Pinch her right ear, and give her a toueh of the heel.' Gafar did so, and away went the mare like lightning, speedily rendering further pursuit hopeless.

"The pinch in the car and the touch with the heel wcre the secret signs by which Jabal had been used to urge his mare to her utmost speed. Jabal's companions were amazed and indignant at his strange conduct. ' $O$, thou father of a jackass!' they cricd, 'thou hast cnabled the thief' to rob thee of thy jewel.' But he silenced their npbraidings by saying, 'I would rather lose her than sully her reputation. Would you have me suffer it to be said amoung the tribe, that another mare had proved fleeter than mine? I have at least this coinfort left me, that I call say she never met with her match.'"

When you enter the stable, in which is the horse to be cxperimented upon, stand still for a short time and let the horse observe you, and as soon as he stands quiet advance slowly, upon the left or near side, on a line with the shoulder, your right hand hanging by your side- 


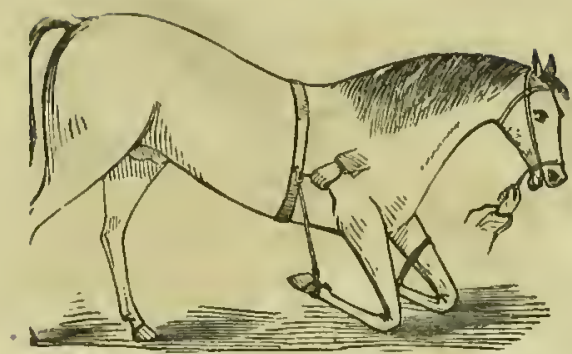

Fre. 3. THE HORBE IN A KNERLLNG POBTURE PREPARATORY TO LTUNG DOWN.

the left bent at the elbow, with the hand projecting. As you move forward go not too much toward his head or eroup, so as not to make him move either forward or backward, thus keeping your horse stationary; if he does move a little either forward or backward, step a little to the right or left very eautiously; this will keep him in the right place. When almost in eontret stand niotionless for a seeond or two, giving the animal another opportunity to survey you, then, speaking in a soothing tone, place the hand lightly upon the shoulder, working up toward the neck, stroking in the direetion in which the hair lies, down the side and front of the face to the nostrils. When the nose is reached suffer the hand to remain, that the horse may smell of it two or three times, and then as Mr. Rarey facetiously remarked, "you've got the animal." Now halter seeurely. Next in order, pass down the neek to the shoulder" and onward to the fore-arm, when you must prevail upon the horse to lift the leg which is fastened in the manner deseribed in our illustration, No. 1. A looped strap that ean be slipped over the kuee is the most expeditions. We will here remark that the floor should be liberally eorered with straw (tan-bark or saw-dust is better), to prevent any injury resulting to the knees, and it would be well to apply knee-eaps. While in this position, after letting him stand for a sliort period, buekle a strong surcingle around the horse, the surcingle having a loop upon it, (see fig. 2,) then fasten a strap around the fetlock of the off leg, passing the other extremity of the strap through the loop. When this portion of the business is completed you are ready for aetive operations.

The object now is, to baek the horse about the stable until he is tired and evidently wishes to lie down, then eompel him to move forward, and when the animal lifts the of foot for that purpose, draw npon the strap fastened around that leg, thns elevating it to a like position with its mate. The proeedure is portrayed in our second engraving. Just as soon as this strap is drawn tiglitly, scize the halter elose to the head and let the animal down easily upon his knees, as seen in fig. 3 . This is a critical period, and the operator must possess coolness and energy to prevent disaster to himself or the animal. When the horse atteinpts to rise, pull his head around toward the shoulder and his demonstrations will prove futile. Bear your weight against his hips, and by voiec and action endeavor to give him au idea of your wishes, continuing the movements as long as it is necessary, when he will 


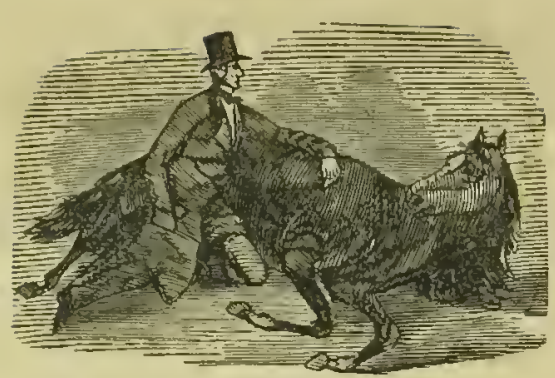

Fia. 4. LTING DOWN AND AUBBUED.

finally lie down. As soon as he is down (see fig. 4) and his struggling has eeased, earess his faee and neek; landle every part of his body, making yourself familial as possible. When in this position a slort time, remove the straps, straighten out the limbs, fondle with him as mueh as you ehoose, and in fifteen or twenty minutes let him rise again to his feet. Repeat this operation, removing the straps as soon as he lies down, and in from two to five trials he is eompletely subdued-he will follow you like ả dog, and you may take any liberties with him without a fear as to the result. If a thorough course of instruetion is given-and he must be educated; no boy's play about it-he will seck the floor if you simply raise the fore-leg and give the eommand, "Lie down, sir."

We give the following rules for the gnidanee of any who may wish to praetiee, simply remarking that their strict observance is imperative:

First. The horse inust not be foreed down by violenee, but must be tired out until he has a strong desire to lie down.

Second. He must be kept quiet on the gronnd until the expression of the eye shows that he is tranquilized, which invariably takes place by patiently waiting and gently patting the horse.

Third. Care must be taken not to throw the horse upon his neek when bent, as it may easily be broken.

Fourth. In baeking him no violenee must be used, or he may be foreed on his haunelies and his baek broken.

Fifth. The halter and off rein are held in the left hand, so as to keep the head away from the latter; while, if the horse attempts to plunge, the halter is drawn tight, when, the off-leg being raised, the nninal is brought on lis knees, and rendered powerless for offensive purposes.

Ciltching the Colt. - If the eolt is in the pasture, approaeh kindly and quietly, extending but one arm, and as you move toward him speak soothingly. If any diffieulty is eaused by his movements to aroid contact, leep the temper eool and persist in the effort to its eompletion, whieh eannot exeeed a few minutes. If you rush after him with arms swinging, and hallooing, he fears bodily harm, and will exert his utmost strengtli to eseape. This should not be-from first to last the presenee of man should never be eonneeted with the fear of injury.

Stabling the Colt.--Mr. Rarey ealls stabling the inost wary eolt a ten 
minutes' job. Hitch a gentle liorse by the stable door, and when all obstructions are removed, approach the colt on the opposite side quietly and slowly. To avoid you, he will move toward the horse and unsuspiciously enter the stable. The doorway is a novel thing to him-he possesses not the least idea of its purpose-he sees an opening and passes in to get away from those coming too near him, and the proximity of the trained horse insures his safety. Shonld he escape, patiently repeat the process. When secured, lead away the horse and give the colt a handful of grain.

General Rules.-As general rules for the varions operations, Mr. Rarey recommends that the shed or stable used should be light, and high enough to admit of a man's riding around without danger to his head; that ehickens, swinc, and other animals be excluded, as serving to attract the attention of the horse; that on no account shall any person aecompany the tamer, or be present at his operations, in order that the attention of the horse be not divided betwoen two or more objects; that before entering the stable the tamer shall know accurately all the processes he intends to go throngh with the horse; and that sufficient time must be given the animal, at each stage of the proceedings, to fully coinprehend what is being done, and what is wanted of him.

Putting on the llalter.-After your introduction to the colt, and by familiarity he has become at ease in your presence, you may proceed to halter him. A rope halter should never be used-one made of leather and properly fitted is the article needed. Approach him, and, after a few caresses, smoothing his head and neck without moving, fasten the end of the halter-strap about his neek. You stand at the left side of the eolt. Laying your right arm across his neck, put, with your left hand, the long or buekle end of the upper part of your halter under his neck; hold it loosely with your right hand, and then loose your strap. Now yon ean lower the upper part; slip his nose into the appropriate place, and buekling the upper part, you have haltered your colt without in the least frightening him. Let him rum around you, taking care never to check him roughly or draw hin violently in any direction. Gradnally approach him by shortening your hold upou the halter, until you can lay your land upon his neck and again caress. When you have repeated this operation a few times, he will suffer you to reach his side withont flying back or running away, and be is now ready for taking an advance step in his education.

Leading the Colt.-Up to this period the colt is ignorant of his strength, and it behooves the instructor to keep him so. If violence is resorted to-if the attcmpt to make him follow is instituted by pulling-he resists, and a battle commences. Stand a little on the near side, rub the nose and foreliead, pull gently upon the strap, touching at the samo time the hind-legs lightly with a whip, and he will start and advance a few steps. Repeat the operation several times, and he will soon learn to follow by gently pulling upon the halter.

Sadding and Bridling,-Dnring the manipulations heretofore described, the mouth of the young colt should be frequently handled. Put a snafte between his teeth, holding it with one hand while you caress him with the other. After a short time he will permit the bridle being placed 
upon him. The proccss of saddling is minutely described by Mr. Rarey, and we quote his remarks thereupou from the London papers. Mr. Rarey says :

"The first thing will be to tie each stirrup-strap into a loose knot, to make them short and prevent the stirrups from flying abont and hitting him. Then double up the skirts and take the saddle under your right arm, so as not to frighten him with it as you approach. When you get to him, rub him gently a few times with your hand, and then raise the saddle very slowly, until he can see it, and smell and feel it with his nose. Then lct the skirt loose, and rub it very gently against his neck the way the hair lies, letting him hear the rattle of the skirts as he feels them against him; each tine getting a little further backward, and finally slipping it over his shoulders on his back. Shake it a little with your liand, and in less than five minutes you can rattle it about over his back as much as you please, and pull it off and throw it on again, without his paying much attention to it.

"As soon as you have aceustomed him to the saddle, fasten the girth. Be careful how you do this. It often frightens the colt when he feels the girth binding him, and making the saddle fit tight on his back. You should bring up the girth very gently, and not draw it too tight at first, just enough to hold the saddle on. Move him a little, and then girth it as tight as you choose, and he will not mind it. You should see that the pad of your saddle is all right before you put it on, and that there is nothing to make it liurt him, or feel unpleasant to his back. It slould not have any loose straps on the back part, to Aap about and scare him.

"After you have saddled him in this way, take a switch in yourright hand to tap him with, and walk abont in the stable a few times with your right arm over your saddle, talking hold of the reins on each side of his neck with your right and left hands, thus marching him about in the stable until you teach lim the use of the bridle, and can turn him in any direction, and stop him by a gentle pull of the rein. Always carcss him, and loose the reins a little every time you stop him."

Mlounting the Colt.-The wcight of the arm in the saddle has accustomed him to a slight burden. Now get a block, or mounting-stool, about eiglteen inches high, and place it at his side. Raise yourself very quietly upon the block, and when you have done so, loosen the stirrup-strap upon the rear side, place your foot in the stirrup, seize the off side of the saddle with the right hand, and cautiously bear your weiglit upon the stirrup and hand. After repeating this operation several times the colt learns there is nothing hurtful, and you must now lift yourself very quictly into the saddle. Once upon his back, speak gently to him, and if he does not move, pull the uear rein a little and he will start. Repeat all the operations of getting on and off, and riding round, for a couple of hours.

The True Way to Bit a Colt.-The practice of placing a bitting harness upon a colt the first thing donc with him, and buekling the bitting rein as tight as it can be drawn, as is frequently the case, mects the severc and just condennation of Mir. Rarey. This is one of the most cruel punishments that can be inflicted upon a colt, and to one that is in the 
habit of earrying the head low, eanuot fail of proving injurious. A horse should be well aeeustomed to the bit before you put on the bitting harness, and when you first bit him you should only rein his liead up to that point where he naturally holds it, let that be high or low; he will soon learn that he eannot lower his head, and that raising it a little will loosen the bit in his mouth. This will give him the idea of raising his head to loosen the bit, and then you ean draw the bitting a little tighter every time you put it on, and he will still raise his head to loosen it. By this means you will gradually get his liead and neek in the position you wish lim to earry it, and give him a graeeful earriage without hurting him, making hiin angry, or eausing his unouth to get sore.

Putting on the llaruess.-The first requisite is a harness that will fit, and a little attention to this will freilitate inatters very mueh. The eollar needs speeial eare, as lumireds of horses liave been spoiled by those the ehief features of which were defects. Take the liarness into the stable, and go through the same proeess as with tlie saddle, letting the colt examine it as mueh as he desires; then put it on with eare. When the operation is eompleted, put on the lines, using them gently, as the tonel, if he is skittish, will startle him. Lead him baek and forth until the fitting of the harness eauses no disquietude, then take hold of the end of the traees, pulling slightly at first, and finally hiteh him to whatever you wish him to pull.

To Ilitch up the Colt.-As the eolt has never paid any partieular attention to a bugroj or earriage, and does not know its uses, great caution must be = userved on his introduction. Lead him gently to it; let him P.sdume it in his own way-by sight, smell, and the exeleise of the sense of feeling - and lead him all around it. Presently he will eease to notice it. Now draw the slrafts to the left, and plaee him before the buggy. One man stands at his head. 'The other, at lis right side, gently lifts the shafts, keeping one hand the while upon the colt's baek, and drops the shafts on either side. They must not toueh him as they are brought down. It is a nice job, and must be performed very delibelately. Wlien you onee have him between the sluats, shake them, so that lie may not only liear but feel them against him. At first he is a little touchy. When he no longer minds them, you ean fasten him up; and while the man at his head slowly leads him along, you work behind, get the lines over his baek (whieh inust be earefully done), and get in. Then you must not let him go faster tlan a walk. This Mr. Rarey insists upon, saying that the horse eamnot at first eomprehend the multifarious arrangements to whieh he is liteled, and if hurried is eonfused. If the horse is very wild, or attempts to kiek, Mr. Rarey ties up one foot as seen in our illustration (fig. 1).

We liave thus gone through the mode of training an unbroken eolt to the saddle and hamess, and to perfect doeility, and shall now briefly treat of some other natters pertinent to the subjeet under eonsideration.

Blinkers onl llorses.- Thongh not directly eonneeted with the proeess of horse-tanning, we eannot refiain from giving the opinions of Mr. Rarey upon the use of "blinkers." These we have long eonsidered not only a useless appendage to the harness, but, in a greater or less degree, 
deleterious-affecting the sight-and have hailed, with gratified feelings, the slight movement that has been made in this country to dispose of them. Mr. Rarey says :

"I take great pleasure in stating that all my experience with and observation of horses proves elearly to me that blinkers should not be used, and that the sight of the horse, for inany reasons, should not be interfered with in any way. Horses are only fearful of objects which they do not understand, or are not familiar with, and the cye is one of the prineipal mediums by which this understanding and this familiarity are bronght about.

"The horse, on account of his very amiable nature, can be made, in the eomrse of time, to bear alnost any thing in any shape; but there is a quicker process of reaching his intelligence than that of wearing it into him through his skin and bones; and he, however wild or nerrous, ean be taught in a very short time to understand and not to fear any object, however frightful in appearanee. Horses can be broken in less time and better withont blinkers; but horses that have always worn them will notice the sudden change, and must be treated carefilly the first drive. After that, they will drive better without the blinkers than with them.

"I have proved, by my own experinents, that a horsc broken without blinkers can be driven past any omnibus, eab, or carriage, on a parallel line as close as it is possible for him to go, without ever wavering or showing any disposition to dodge. I have not iu the last eight or ten years, constantly handling horses both wild and nervous, ever put blinkers on any of them, and in no case have I ever had one that was afraid of the earriage he drew behind him or of those he passed in the streets.

"The horse's cye is the life and beauty of the animal, as well as the index of all his emotions. It tells the driver, in the most impressive charactel's, what the horse's feelings are. By it he can tell the first approach of fear in time to mect any difficulty; he can tell if he is happy or sad, lungry or weary. The horse, too, when permitted to see, uses his eyes with great judgment. He sees better than we do. Ile can measure distances with his eyes better than we ean, and, if allowed free use of them, would often save himself, by the quiekness of his sight, from collisions, when the driver would fail to do so by a tinicly pull of the reins. It would also save many accidents to pedestriaus in the streets, as no horse will run on to any person tliat he ean see. **** I have yet to find the man who, laving once left thein off, eould ever bo persuaded to put them on again. They are an unneessary and injurious incumbrance to the horse, and I feel confident, if the eabmen of London will leave them off for onc year, that blinkers on eab-horses will never be seen again in the streets, and will only be a thing to be read of as one of the follies happily reformed in the nineteenth cen-

To Drive a Kicking Ilorse--Bend up the near fore-foot (see fig. 1, first position), then draw a loop over the knee and up to the pastern joint, and secure it there. The horse camnot kick while standing on three legs, and there is this further advantage, handling in this plight con- 
quers inmediately. Sometimes he gets very angry, strikes the knee on the ground, and otherwise endeavors to get the knee loose. You can sit down and look at him at your ense till he gives up. When this takes place, let down the horse's foot, rub lis leg, and caress lim; let him rest a little, and then put the foot up again. Repeat this several times, till the horse has learned to walk on three legs. Yon then put the liorse into a sulky. Having his foot hitehed up, he eannot kick, howsoever much he may desire to; nor can he run away, if ever so much inclined. Mr. Rarey's theory is, that a horse kicks because he is afraid of something behind him, or of the man or other object approaching him. And he first incapacitates him from kicking, and then accustoms him to whatever he was before in fear of, be this a rattling vehicle, or a man's hand on his liecls. A very few hours' time suffices to accomplish this taming of the most vicious brute.

About Balky llorses.-Mir. Rarcy asserts that the hoise knows nothing naturally about balking-and that the animal which practices any of the various freaks known under this name, does so either because bad management has led him into bad habits, ol because, though willing to obey, he does not comprehend what his master desires of him. In all these cases, therefore, he maintains that the whip and the loud angry voice are entirely out of place, and only make bad worse. If the horse balks he is excited. The first thing, therefore, is to go to his head, speak to him kindly, pat and smooth lim, and thus get him quieted down. The whip nust not be shown at all. When he is calmed you can start your tean. It is not a sudden jerk against the collar which moves the load, but a steady pressure. All kinds of violence, therefore, tend to the wrong course. The object is to start the horses even; and as the balky horse generally plunges first, you are to kcep him back gently till they can both take the strain together. A quick way to accomplish this-but not the surest way, Mr. Rarey says-"is one I liave myself seen practiced in Ohio. This is, to lift one fore-foot of the balky horse, and start the team. As he presses forward, you let lim have his foot, when he will almost always take the strain with his matc." A better way, according to Mr. Rarey, is to let the lines hang quite slaek, get the horses calmed down, and then stand in front of then, and turn them gently to the right without letting them bring a strain upon the traces. From this tum them as gently to the left. By this time they will be moving in unison, and, as you turn them again to the right, steady them iu the collar, and they will go off together easily. If yon are paticnt and eareful, you can make any horse pull true by this management.

STABLE MAYAGEMENT.-The first thing of importance in the treatment of a horse is the building which is provided for him, or his stable. Perlaps the best way of treating the subjeet is to show what his stable onght not to be, and that, unfortunately both for the animal and his owner, will be to show what it too generally is.

In the first place, it ought not to be dark; and in this respect there are but too many proprietors of horses who will, in their practice at 
any rate, be at issue with us, though the total or partial blindness of their horses should have taught them better; for from this cause in general springs the blindness of the animal, whieh, by nature, is no more predisposed to blindness than is his owner. And not ouly does a dark stable affect the sight of a horse, but his general health also, espeeially, as is often the case, if he be immured in his stable for days together. Light is just as essential to a healthy condition as food itself, and an animal ean no more thrive without the one than the other. The man who invented dark stables was no doubt the progenitol of him who invented the barbarous practice of docking and nicking horses' tails.

The next thing to be considered is ventilation; and this-as stables are commonly ventilated, or rather not ventilated-is believed to be of no moment whatever. In many old country stables we find the door made of two portions, the upper one opening whilst the lower one is made fast. This is very well for farm stables; but this construction is not adapted for those where horses of the higher elass are kept. With a door of this description, open at the top, and a lofty window at the other end, open at the top also, a draught takes plaee which is above the horse's back, and will ventilate the stable thoroughly, espeeially if the stable be lofty, as it always should be, though it is in general eonstructed so as to have a hay-loft over it-a great eonvenience, no doubt -but one which should not be permitted to reduce the height of the stable itself to some seven or eight feet; in which circumscribed space a tean of horses are often confined for the night, under the necessity of breathing the same air as they have expired. To expeet horses to be lealthy or sound under such a eondition is to expect an impossibility.

Ventilation.-A little consideration will show the importance of perfect rentilation. The air which the horse expires is as totally different a substance from that which he inhales as wood is from iron. He inhales atmospheric air, and the constituents of this pass through his lungs, and into his blood; he expires earbonie acid gas, one of the geses most inimical to animal life, as any mau may eonvince himself who will go down into an old unused well. If this deadly gas be not carried off by proper ventilation, it becomes mixed with the atmospheric air of the stable, and is again inhaled, to the great injury of the animal's liealth. The greatest eare is also requisite that it should be thoroughly earried off, and this can only be done as it eomes out from the animal's body; when cold, it is heavier than atmospheric air, and sinks to the floor of the stable, in which ease it is not so easily got rid of, but may lay the foundation of diseases innumerable, and will eertainly shorten the usefuluess, if not the life, of the animal. From this, as mueh as from any other cause, horses may truly be said not to live out half their days.

A thorough ventilation is as necessary in the winter as the summer, and there is infinitely less risk of injuring the horse by cold than by allowing him to breathe expired air over again. If aceustomed to proper ventilation, he will never take cold from any judicions meaus adopted
to promote his health and eomfort. Pure air in winter is as necessary as in summer; whilst in the summer the inore that can be admitted to eool the stable the better. The building should, then, be so con- 
strueted, as in sunmer to admit the greatest possible quantity of cool air, and in winter to admit sufficient for the preservation of the purity of the atmosphcre, without runuing any risk from cold draughts, Care must also be taken not to admit dranghts of air near the hor'sc's heels, or diseased lcgs will be the result. Draughts eannot be too carefilly guarded against, nor is it requisite that such should oecur, if a little forethought only be exercised. Some writers on the subject adrocate a chimney-shaft to be erceted in the stable, by which the foul air can best escape, and also the admission of fresh air over the aninal's head by means of perforated zine.

Cleanliness. - The next consideration, and it is not less inportant than cither of the preceding, is that of eleanliness. 'Too many persons be. lieve, or they act as so believing, that the more a horse stands and slecps among the filth of his own litter; the more he thrives. This is an error of ignoranee or of idleness, perhaps both combined. The effect of it at any rate is to make the animal, in addition to breathing his own breath again, inhale the fetid ammoniacal steams which arise from his own ordure and urine. Wo have even heard farmers defend this mode, on the ground that the manure is better, as though the manure were worth any thing in comparison with the horse.

The Stable Floor. - A brick or stone stable floor is the best; if the latter, the stone should be ronghened with small furrows, and in either case a deep drain sunk outside of the stable is necessary for keeping it perfectly dry, without which either brick or stone floors will be prejudicial from danp. This is of the utmost importanee. Neither slould such drains be used to earry off the urine. The floor should slope an inch to a yard, but only to the gutter which earries off the urine. Indeed, if this is earricd off by an iron pipe with suitable openings, so much the better. A tub sunk outside the stable as a receptacle for the urine, will soon amply repay the farmer for his trouble; it is too valuable to be permitted to diffuse itself over the dung-heap in the yard, to be washed away by the first shower of rail.

Litter should always be allowed for a horse to stale upon, as it is easily removed, and a little gypsmn thrown down oceasionally will lecp the stable free from smells. Nothing ean be inore offensive to either horse or man than the smell of putrid urine, whilst if this be permitted to run into a proper reecptacle, and a little sulphuric acid added oceasionally, nothing ean exeed its value as a manme, which the farmer should be as careful to preserve as he is the corn which it fertilizes.

Within reason, the more room a horse has in his stall the less hablo will be be to swollen legs. In no iustance ought he to have less room than six feet, and if ten ean be afforded him, so much the more will he thrive, the comfort being especially felt after a hard day's work, Loose boxes are indispensable to hor'ses of value.

A perfect stable should never have a hay-loft over it. This of eourse will give a little more trouble to the stable-man, but where the comfort of a horse is concerned, that is of no eonsequenee whatever. A deep manger with two or three iron bars across is far preferable to a rack or well for the reception of hay, and will more effeetually prevent waste. II arrangrement for water should also he provided. The front inust of 
course be boarded up, with the exception of the part from which the borse eats. The advantage of this arrangement would be, that all the hay would be catcn, and not pulled down, as is gencrally the ease, and trodden underfoot amongst the littcr. Much hay will be saved by the usc of a decp manger as a substitute for a rack; and an cqual saving would take place in grain if the manger were made to slope slightly inward instead of outward, as is usually thc casc. It would excecdingly puzzle a wastcful or mischievous horsc to throw his corn out of such a manger if deep enough; but for this the manger as usually constructed affords him every facility.

Dung never ought to be allowed to be swcpt up in a eorner, as is frequently the casc, and all wet litter should be removed. In short, the more pains that are taken relative to a horsc's eomfort in a stablc, the more will he repay those pains; and the farner espeeially ean have no better assurance that the more the horses thrive, the morc will he himself thrive. The very fact of his attention to his horses independeutly of the more cffective work arising therefrom, will beget a similar habit of attention to every thing else.

TIIE HORSE'S F00D.-This should be oats and hay of the best quality; beans for hard-working horses oceasionally varicd with earrots or Swedes, bran mashes, and under some eircumstanees linsecd gruel. Many persons are not aware that the priec of musty grain and bad hay is vastly dearer than that of the same commoditics of good quality, and that the worse the quality the higher the cost. It is so nevertheless, for whether the purchaser of inferior artieles bargain for it or not, he always purehases, with them indigcstion, fonlness of blood, looseness of the bowels, genernl debility, and glanders, all of these bcing too eostly to be purchased into any stable. We once kncw a farmer whose practice it was to scll all his best articles and kecp the refusc of the farm for his own horses; the eonsequenec was, that lic never was without glanders or some other disease in his stablc; and there was not a earter in the parish who did not give his tcam a wide berth wherever he met it with his own horses. It was the man's system, neverthcless, and he cither eould not sec its bancfulness or he would not alter it; so he died at last frow it, having caught a glanderous infection from his own stable. Mr. Spooncr, in speaking of this subject, thus testifies his ow'll expcrienee: "Thane known a serious loss sustaincd by a proprictor of post and conch horses, from kecping a considcrable stoek of oats and ncglceting to turn them; many horses became glandered and fareicd, apparently in consequenee of this circumstance."

Whole or Bruised Gritin,-Much has been said of late respecting the advantagc of bruising oats, aud various machines are much in vogue for the purpose. Mr. Spooner says of them, "they are apt to produce diarrlıea, espccially it the anmal is worked hard." It is further alleged that many liorses will not cat them with an appetitc, and the opponents to the system go further, urging that unhuised oats excitc a flow of saliva necessary to perfeet digestion, whieh is not the easc with those which are bruised. The cxplauation to the first of these questions supplies a very strong recommendatiou. The stomach having derived a sufficient quantity of nourishment from a moderate portion does not re- 
quire more. With referenee to the flow of the saliva, without entering upon the question how far it is neeessary to assist digestion, no animal ean swallow its food without a suffieieney of saliva to assist the aet of deglutition; and it is not reeommended to reduee the oats to flour, but merely to bruise them. Many persons faney that by giving oats in small quantities and spreading them thinly over the manger the horses will be indueed to mastieate them. Those who have watehed their operations will find that a greedy-feeding horse will drive his eorn up into a heap, and eolleet with his lips as mueh as he thinks proper for a monthful.

Little if any advantage arises from eutting hay into ehaff, espeeially for the most valuable kiud of horses. It is done in eart stables to prevent waste, which is often enormous in those departments where horses are permitted to pull the hay out of their racks and tread it underfoot.

The state of perfeetion to whiel the higher elasses of the horse have been brought in this eountry, is attributable to the great attention devoted during a long period of time to the seleetion of the best deserip tions for the purpose of perpetuating the speeies; the treatment they have reecived under the infuence of a propitious elimate, and the nature of the food with which they have been supplied; greater improvements are eapable of being realized by judieious management.

Value of Diflerent hinds of Food.-Professor Playfair, who has made experiments on the quantity of uutritious matter eontained in different kinds of food supplied to animals, found that in one hundred lbs. of oats, eleven lbs, represent the quantity of gluten wherewith flesh is formed, and that an equal weight of hay affords eight lbs. of similar substance. Both hay and oats eontain about sixty-eight per eent. of unazotized matter identieal with fat, of which it must be observed a vast portion passes off from the aniual without being deposited. By this ealeulation, it appears that if a horse eonsumes daily four feeds of oats and ten Ibs. of hay, the nutriment which he derives will be equivalent to about one lb. eleven $o z$. of musele, and thirteen and a balf lbs. of superfluous matter, which, exelusively of water, nearly approximates the exhaustion of the system by perspiration and the various evacuations.

Oats have been seleeted as that portion of the food whiels is to afford the prineipal nourishment. They eontain seven hundred and fortythree parts out of a thousand of the nutritive matter. They should be about or somewhat less than a year old-heavy, dry and sweet. New oats will weigh ten or fifteen per eent. more than old ones, but the differenee eonsists prineipally in watery matter, whieh is gradually evaporated. New oats are not so readily ground down by the teeth as old ones. They form a more glutinous nuass, diffienlt to digest, and when eaten in eonsiderable quantities are apt to oeeasion eolie, or even staggers.

Barley is a common food of the horse on various parts of the Continent, and, until the introduetion of the oat, secms to have eonstituted almost his only food. It is more nutritious than oats, eontaining nine hundred and twenty parts of nutritive matter in every thousand. There seems, however, to be solnething neeessary besides a great proportion of nutritive matter, in order to render any substanee strengthening, 
wholesome, or fattening; therefore it is that in many horses that are hardly worked, and indeed, in horses generally, burley does not agree with them so well as oats. They are oceasionally subject to inflammatory eomplaints, and partieularly to surfeit and mange.

When barlcy is given, the quantity should not exceed a peck daily. It should always be bruised, and the chaff should eonsist of equal quantitics of hay and barley-straw, and not cut too short. If the farmer has a quantity of spotted or unsalable barley that he wishes thus to get lid of, he must very gradually aceustom his horses to it, or he will probably produce serious illness among them. For horses that are reeovering from illness, barley in the form of malt is often serviceable as tempting the appetite and recruiting the strength. It is best given in mashes-water considerably below thc hoiling heat being poured upon it, and the vessel or pail kept covered for half an hour.

The Swedish Turnip is an article of food the value of which has not beeu sufficiently appreciated, and particularly for agricultural horses. Although it is far from containing the quantity of nutritive matter which has bcen supposed, that which it has seems to bc capable of easy and complete digcstion. It shonld be sliced with chopped straw, and without hay. It quickly fattens the horse and produees a sinooth glossy coat and a loose skin. It will be a good practice to give it once a day, and that at night when the work is done.

Carroks. - The virtues of this root are not sufficiently known, whether as contributing to the strengtl and endurance of the sound horse, or the rapid recovery of the siek one. To the healthy horse they shonld be given slieed in his chaff. Half a bushel will be a fair daily allowance. There is little provender of which the horse is fonder. The following aceount of the value of the carrot is not cxaggerated: "This root is held in nucl estcem. 'There is noue bettcr, nor perhaps so good. When first given, it is slightly diurctic and laxative; but as the horse beeomes aecustomed to it, these effects cease to be produeed. They also
improve the state of the skiu."

Polatoes have been given, and with advantage, in their raw state sliced with chaff; but wherc it has been convenient to boil or steam them, the benefit has been far more evident. Purging has then rarely ensued. Some have given boiled potatoes alone; and horses, instead of rejecting them, have soon preferred them cven to the oat; but it is better to mix them with the usual manger feed, in the proportion of one pound of potatocs to two and a half pounds of the other ingredients. The use of the potato must depend on its cheapness and the facility for
boiling it. IIalf a dozen horses would soon repay the expense of at steaming boiler in the saving of provender, without taking into the aceonnt their improved condition and capability for work.* A horse fed on potatoes should have his quantity of water materially curtailed.

\footnotetext{
* Professor Low says that fifteen pounds of potatoes yield as mueh nourishment as four pounds and a half of oats. Fon Thayer asselts that three busliels are equal to one hundred and twelve pounds of hay; and Curwen, who tried potaces extensively in the feeding of horses, says that an acre goes as far as four aeres of
hay.
} 
Effict on the 0fispring,-It is now generally known that the embryo offspring partakes of the health or condition of the dam, therefore the food with whicl the mother is supplied must affeet the foal. This is a subjeet too cornmonly disregarded by breeders, although it is constantly demonstrated after the foal comes into life. Ifa mare be supplied with food which produces relaxation, her foal will be in the same state; and constipation is reeognized in a similar manner. The propricty of supplying a brood-mare with the best and most suitable kinds of food during pregnaney cannot be too strongly impressed. In the management of young stock every effort should be made, by giving them food which is adapted to the purpose, to bring them to maturity as early as possible; by these means the texture and development of the bones, the sinews, and the museles is greatly aecelerated. The constitution of each animal must be consulted, and it is highly important, if the aeme of condition is to be attained by animals when they arrive at an age of maturity, that the growth and gradual developinent of their franes should be eomposed of those healthy and invigorating materials, upon which the strueture of eondition can be raised. To accomplish this, hay, oats, and oecasionally beans, must form the prineipal items of food, and grass should be provided only in limited supplies during the summer months.

Grass, it may be observed, loses two-thirds of its weight, and a still greater proportion of bulk, when eonverted into hay; but that extraneous matter eonsists of moisture, posscssing no portion of fibrine, eonsequently it contains none of those elements which increase muscular development. If a horse besupported upon grass alone, he must eat a vast quantity - equal to more than three times the proportion of layto derive an equivalent anount of nourishment; being very full of sap and moisturc, it is quickly digested; consequently, the animal must be eontinually devoming it. This distends the stomach and bowels, and impairs the faculty of digestion; for the digestive powers require rest, as well as the other organs of the body, if they are to be preserved in a healthy state. The muscular system is debilitated, and fat aeeumulates; flatulent colie or gripes is produced, which not unfrequently becomes eonstitutional. Nothing can be more erroneous than the antiquated impression, that the purgative properties of young grass in the spring are condueive to the healthy state of the horse. When the morlus operandi of that description of food is explained, the supposition of its being caleulated to produee benefieial effects must vanish. The young grcen herbage is extensively overcharged with sap and noisture, of a crude, aerimonious nature, and it exists so abundantly, that a eonsiderable portion of it cannot be taken up by the organs destined for the seeretion of mine, or by the absorbent vessels of the body; a great quantity of this superfluous tluid, therefore, passes into the intestines, and is thus diseharged in a watery state. But the mischief does not terininate innediately on the subsiding of the purgative action; the absorbent vessels, having been overloaded, become distended and relaxed, and soine time intervenes before they resume their liealthy tone, under the most judicious treatment. This is clearly exemplified by the habitual tendeney which many horses exhibit of having swelled legs. When 
this evil exists, any persons who entertain a doubt as to the primary eause may readily eonvinee themselves, by investigating the eourse of treatment to which the animal has been subjeeted. Horses which are reared on wet, marshy land are invariably aftlieted with this relaxed condition of the absorbent vessels of the legs. Constant supplies of green sueeulent food render the defeets eonstitutional, and the most seientifie stable management is often frustrated when sueh animals are required to perform ordinary labor; their legs fail, not from anatomieal defeets, but from the eause explained, which operates injuriously upon a strueture whieh is naturally perfeet.

Superfieial judges of horses do not mark the differenee between the appearanees of a fat and a museular-formed animal. If the bones are eovered, the points filled out, and the general eontour looks pleasing to the eye, they coneeive that every requisite is aeeomplished. A more fallacious impression eannot exist. A horse of very moderate pretensions, if in perfeet eondition, will prove himself infinitely superior in the quality of enduranee or enpability to perform work, than one of a higher eharaeter whieh is not in eondition. If two horses are ridden side by side, at the moderate paee of seven or eight miles in the hour, on a warn day, in the summer, one of whieh has been taken out of a grass field, and the other fed on hay and grain, the differenee will be very soon deteeted. The grass-fed horse will perspire profusely, yet the other will be cool and dry. This propensity to perspire likewise proves that the system of the former is replete with adipose deposit, and fluids destined to produee that substanee; an unneessary eneumbranec, and in sueh quantities opposed to freedom of aetion.

Under an impression that an abundanee of luxuriant grass will inerease the flow of milk, it is frequently given to brood mares, but if it has the effeet of produeing relaxation, it is exeedingly prejudicial. A moderate portion of good milk is far preforable to that whieh is weak and poor. Thorough-bred mares are not unfrequently defieient in their laeteal seeretions, more so than those of a eommon deseription. It is obviously neeessary that either class should be supplied with good and nutritious food for the purpose of augmenting it when insuflieient, but the nature of the food requires to be regulated by the eonstitution
of the individual.

A inistaken notion of ceonomy frequently induees persons to turn their loorses into the grass fields during the summer months. A few words may serve to dispel that delusion. Twenty-two bushels of oats, allowing one bushel per week, which is suffieient for young stoek or horses not in work, from the 15 th of May to the 16tl of Oetober, may bo estimated as the produee of a trifle more than half an aere of land. From ten to twelve huudred weight of hay may be estimated as the produee of another half-aere, althougl a ton and a half per aere, is not more than an arerage erop on land in good eondition. It will require an aere of grass land, eapable of produeing a ton and a half of hay, to support a horse during the above-named period. When the relative value of a horse whiel has been kept on hay and grain, is eompared with that of one whieh has been grazed, the verdiet will be considerably
against the latter. 
A simple but invaluable appendage to the eart-stable is the nose-bag. In order that the lungs of the horse may liave their full play, and espeeially that the speed of the horse may not be imperled, an exceedingly small stomaeh was given to him. It is, consequently, soon emptied of food, and hunger, and languor, and indisposition, and inability to work, speedily succeed. At length food is set before him; he falls ravenously upon it; he swallows it faster than his contracted stomach ean digest it; the stomach beeomes overloaded; he cannot, from the peculiar eonstruction of that organ, get rid of the load by romiting, and the stomach, or some of the ressels of the brain, becomes ruptured, and the animal dies. The farmer attributes this to all unkuown or aceidental eause, and dreams not that it is, in the great majority of eases, to be traced to voraeious feeding after hard work and long fasting. The nose-bag is a simple but a kind eontrivanee, and an effeetual preventive. No eart-horse on a journey of more than four or five hours, should be suffered to leave the farmer's yard witlout it.

A very slight inspection of the aninal will always enable the owner to determine whether he is too well fed or not sufficiently fed. The size of the horse, and the nature of the work, and the season of the year, will make eonsiderable differenee in the quantity and the quality of the food. The following aceounts will sufficiently elueidate the general eustom :--"Mr. Ularper, of Bank Hall, Laneaslire, plows seven aeres per week, the yeal through, on strong land, with a team of three horses, and allows to cach weekly two bushels of oats, with hay, during the winter six months, and, during the remainder of the year, one bushel of oats per week. Mr. Ellman, of Glynde, in Sussex, allows two bushels of oats, with pease-haulm or straw, with but very little liay, during the winter montlis. He gives one bushel of oats with green food during the summer." There is very little differenee in the management of these two gentlemen, and that probably arising from eircumstances peenliar to their respeetive farms. The grand prineiples of feeding, with referenee to agrieultural horses, are, to keep the animal rather above his work, to give him good and wholesome food, and, by the use of the nose-bag or other means, never to let him work longer than the time already mentioned without being baited.

The horse' of quick work should be allowed as much as he will eat, eare being taken that no more is put into the manger than he will readily dispose of; and that the grain be eonsumed before the hay is given; if the former be not eaten up with an appetite, it must be removed before the stable is shot up. The quantity retually eaten will depend on the degree of work and the natural appetite of the horse; but it may be averaged at about sixty-six pounds of ehaff, seventeen pounds and a half of beans, and seventy-seven pounds of oats per week.

The watering of the horse is a very important but disregarded portion of his general management. The kind of water has not been sufficiently eonsidered. The differenee between what is termed hard and soft water is a eirenmstance of general observation. The former eontains ecrtain saline prineiples which decompose some bodies, as appears in the eurdling of soap, and prevent the deeomposition of others, as in the making of tea, the boiling of vegetables, and the proeess of brewing. It 
is natural to suppose that these different kinds of water would produce somewhat different effects on the animal frame; and such is the fact. Hard water, freshly drawn from the well, will frequently roughen the cont of the horse unaccustomed to it, or causc griping pains, or materially lessen the animal's power of exertion. The racing and the liunting groom are perfectly aware of this; and so is the horse, for he will refuse the purest water from the well, if he can obtain access to the running stream, or even the turbid pool. Where there is the power of choice, the softer water should undoubtedly be preferred.

The temperature of the water is of far more consequence than its harduess. It will rarely harm, if taken from the pond or the rumning stream, but its colduess when recently drawn from the well has often been injurious; it has produced colic, spasm, and even death.

There is often considerable prejudice against the horse being fairly supplied with water. It is supposed to chill him, to injure his wind, or to incapacitate him for hard work. It certainly would do so if, immediately after drinking his fill, he were galloped hard, bnt not if he were suffered to quench his thirst more frequently when at rest in the stable. The horse that has firee access to water will not drink so much in the course of a day as another, who, in order to cool his parched mouth, swallows as fast as he can, and knows not when to stop.

A horse may with perfect safety be far more liberally supplied with water than he generally is. An hour before his work commences, he should be permitted to drink a couple of quarts. A greater quantity might probably be objected to. He will perform his task far more pleasantly and effectively than with a parched mouth and tormenting thirst. 'The prejudice both of the hunting and the training groom ou this point is cruel, as well as injurious. The task or the journey being accomplished, and the horse having had his head and neck dressed, his legs and feet washed, before his body is cleaned he should have his water. When dressed, his grain may be offered to him, which he will readily take; but water should never be given immediately before or after the grain.

GR00MING-Of this little need be said to the agrieulturist, since custom, and apparently witlont ill effect, has allotted so hittle of the comb and brush to the farmer's horse. The animal that is worked all day and turned out at night, requires little more to be done to him than to have the dirt brushed off lis limbs. Regular grooming, by rendering his skin more sensible to the alteration of temperature, and the inclemency of the weatlier, would be prejudicial. The horse that is altogether turned out, needs no grooming. The dandriff, or scurf, which accunulates at the roots of the liair, is a provision of nature to defend him from the wind and the cold.

It is to the stabled horse, highly fed, and little or irregularly worked, that grooming is of so much consequence. Good rubbing with the brush, or the curry-comb, opens the pores of the skin, circulates the blood to the extremities of the body, produces free and hcalthy perspiration, and stands in the room of exercise. No horse will carry a fine coat without either unnatural heat or dressing. They both effect the same purpose; they both increase the inseusible persiration; but 
the first does it at the expense of health and strengtl, while the second, at the same time that it produces a glow on the skin, and a determination of blood to it, rouses all the energies of the frame. It would be well for the proprietor of the horse if he were to insist-and to see that his orders are really obeyed-that the fine coat in which he and his groom so much delight, is produced by honest rubbing, and not by a heated stable and thick clothing, and most of all, not by stimulating or injurious spices. The horse should be regularly dressed every day, in addition to the grooming that is necessary after work.

When the weather will permit the horse to be takell out, he should never be groomed in the stable, unless he is an animal of peculiar value, or placed for a time under peculiar circumstances. Without dwelling on the want of cleanliness, wheu the seurf and dust that are brushed from the horse lodge in his manger, and mingle with his food, experience teaches, that if the cold is not too great, the animal is braced and invigorated to a degree that cannot be attained in the stable, from being dressed in the open air. There is no necessity, however, for half the punishment which many a groom infliets upon the horse in the act of dressing; and particularly on one whose skin is thiu and sensible. The curry-comb should at all times be lightly applied. With many horses, its use may be almost dispensed with; and even the brush needs not to be so hard, nor the points of the bristles so irregular, as they often are. A soft brush, with a little more weight of the hand, will be equally effectual, and a great deal more pleasint to the horse. A hair-cloth, while it will seldom irritate and tease, will be almost sufficient with horses that lave a thin skin, and that have not been neglected. After all, it is no slight task to dress a horse as it ought to be done. It occupies no little time, and demands considerable patience, as well as dexterity.

Exercise,-Our observations on this important branch of stable management must have only a slight referenee to the agricultural horse. His work is usually regular, and not exhausting. He is neither predisposed to disease by idleness nor worn out by excessive exertion. $\mathrm{He}$, like his master, has enough to do to keep him in health, and not enongh to distress or injure him; on the contrary, the regularity of his work prolongs life to an extent rarely witnessed in the stable of the gentlemau. O'ur remarks on exercise, then, must lave a gencral bearing, or have principal referenee to those persons who are in the niddle stations of life, and who contrive to keep a horse for business or pleasure, bnt cannot afford to maintain a servant for the express purpose of looking after it. The first rule we would lay down is, that every horse should love daily exereise. The animal that, with the usual stable feeding, stands idle for three or four days, as is the ease in many establishments, must suffer. He is predisposed to fever, or to greas," most of all, disenses of the foot; and if, after three or four days of inactivity, he is ridden far and fast, he is almost sure to have inflammation of the lungs or of the feet.

A gentleman's or a tradesman's lıorse suffers a great deal more from idleness than he does from work. A stable-fed horse should have two hours' exercise every day, if he is to be kept free from discasc. Nothing 
of extraordinary, or even of ordinary labor, ean be effected on the road or in the field without suffieient and regular exereise. It is this alone which ean give energy to the system, or develop the powers of any aninıal.

The exereised horse will diseharge his task, and sometimes a severe one, with ease and pleasure; while the idle and negleeted one will bo fatigued ere half his labor is aceomplished; and, if he is pushed a little too far, dangerous inflammation will ensue. How often, nevertheless, does it happen, that the horse which has stood inaetive in the stable three or four days, is ridden or driven thirty or forty iniles in the course of a single day! 'This rest is often purposely given to prepare for' extra exertion-to lay in a stoek of strength for the performanee of the task required of him; and then the owner is surprised and dissatisfied if the animal is fairly knocked up, or possibly beeomes seriously ill. Nothing is so eommon and so preposterous as for a person to buy a horse from a dealer's stable, where he has been idly fattened for sale for many a day, and immediately to give him a long run after the hounds, and tben to complain bitterly, and think that he has been imposed upon, if tbe animal is exhausted before the end of the chase, or is eompelled to be led home suffering from violent inflammation. Regular and graduallyinereasing exereise would have made the same horse appear a treasure to his owner.

lixercise should be somewhat proportioned to the age of the borse. A young lorse requires more than an old one. Nature has given to young animals of every lind a disposition to aetivity; but the exereise must not be violent. A great deal depends upon the manner in whieb it is given. To preserve the temper, and to promote healtb, it should be moderate, at least at the begiuning and the temination. The rapid trot, or even the gallop, may be resorted to in the middle of the exereise, but the horse should be hrought in eool.

Ilanagement of the Fret,-This is the only division of stable management that remains to be considered, and one sadly negleeted by the earter and groom. The feet should be earefully examined every morning, for the shoes may be loose, and the horse would have been stopped in the middle of his work; or the elenehes may be raised, and endanger the wounding of his legs; or the shoe may begin to press upon tbe sole or the heel, and bruises of tbe sole or eorn may be the result; and, the horse having stood so long in tbe stable, every little inerease of heat in the foot, or lameness, will be more readily deteeted, and serious disease may often be prevented.

When the horse cornes in at nigbt, and after the harness has been taken off and stowed away, the heels should be well brushed out. Handrubbing will be preferable to washing, espeeially in the agrieultural horse, whose he eovered with long hair, ean seareely be dried again. If the dirt is suffered to aeeumulate in that long hair, the heels will beeome sore, and grease will follow; and if the heels are washed, and partieularly dnring the winter, grease will result from the eoldness oecasioned by the slow evaporation of the moisture. The feet slionld be slopped-even the feet of the farmer's horse-if he remains in tbe stable. Very little elay should be used in the stopping, for it will get 
hard and press upon the sole. Cow-dung is the best stopping to prescrve the feet cool and elastic; but before the stopping is applied, the picker should be run round the whole of the foot, between the shoc and the sole, in order to detect any stone that may have insinuated itself there, or a wound on any other part of the sole.

SIIUEING, ete.-Far more than is generally imagined, do the comfort and healtl of the horse, and the safety of his rider, depend upon shoeing.

In taking off the old shoe, the elenehes of the nails should always be earefully raised or filed off; and, where the foot is tender, or the horse is to be examined for lameness, each nail should be partly punched out.

The edges of the crust are then to be rasped to detect whether any stubs remain in the nail-holes, and to remove the erust, into which dust and gravel have insinuated themselves.

Next comes the important process of paring ont, with regard to which it is almost impossible to lay down any specific rules. This, however, is undoubted, that far more injury lias been done by the negleet of paring, than by earrying it to too great an cxtent. The act of paring is a work of much more labor than the proprietor of the horse often imagines. The smitl, exeept he is overlooked, will frequently give himself as little tronble about it as he ean; and that portion of horn which, in the unshod foot, would be worn away by eontaet with the ground, is suffered to accumulate month after month, until the elastieity of the sole is destroyed, and it ean no longer descend, and its other functions are impeded, and foundation is laid for corn, and contraction, and navicular discase, and inflammation. That portion of horn should be left on the foot which will defend the internal parts from being bruised, and yet suffer the external sole to deseend. How is this to be ascertained? The strong pressure of the thumb of the smith will be the best guide. The buttress, that most destruetive of all instruments, being, execpt on very particular occasions, banished from every respectable forge, the smith sets to work with his drawing knife, and removes the growth of horn, until the sole will yield, although in the slightest possible degree, to the strong pressure of his thumb. The proper thickness of horn will then remain.

The quantity of horn to be removed, in order to leave the proper degree of thiekness, will vary with different feet. From the strong foot a great deal must be taken. From the coneave foot the horn may be removed until the sole will yicld to a moderate pressure. From the flat foot little needs be pared; while the pumiced foot should be deprived of nothing but the ragged parts.

The crust should be redueed to a perfect level all round, but left a little higher than the sole, or the sole will be bruised by its pressure on the edge of the seating.

The hecls will require consiclerable attention. From the stress which is thrown on the inner heel, and from the weakness of the quarter there, the horn usually wears away considerably faster than it would on the outer one, and if an equal portion of horn were pared from it, it would be left lower than the outer heel. The smith should therefore aceommodate lis paring to the comparative wear of the heels, and be exeeedingly careful to leave them precisely level. 
The portion of the heels between the inflection of the bar and the frog should scarcely bc touched-at least, the ragged and detached parts alone should be cut away. The foot may not look so fair and open, but it will last longer witliout contraction.

The bar, likewise, should be left fully prominent, not only at its first inflection, but as it runs down the side of the frog. The heel of the shoe is designed to rest partly on the beel of the foot and partly on the bar, for reasons that have bcen already stated. If the bar is weak, the growth of it shonld be eneouraged; and it should be seareely touched when the horse is shod, unless it has attained a level with the crust.

It will also be apparent, that the horn between the crust and the bar should be carcfully pared out. Every horseman has observed the relief which is given to the animal lame with corns, wlien this angle is well thinned.

The degree of paring to which the fiog must be subjected, will depend on its prominence, and on the shape of the foot. The principle has already been stated, that it nust be left so far projecting and prominent, that it shall be just within and above the lower surface of the shoe; it will then descend with the sole sufficiently to discharge the functions that have been attributed to it. If it is lower, it will be bruised and injured; if it is higher, it cannot come in contact with the ground, and thus be cnabled to do its duty. The ragged parts must be removed, and especially those oceasioned by thrush, but the degree of paring must depend entirely on the prinejple just stated.

Putting on the Shoe.-The shoc should accurately fit the size of the foot; if too small, and the foot is rasped down to fit the shoe, the crust is thinned where it receives the nail, and the danger of puncture, and of pressure upon the sole, is inereased; and a foot so artificially diminished in size, will soon grow over the shoe, to the hazard of considerable or permanent lameness.

The shoe should be properly beveled off, that the dirt, gravel, etc., which gets between it and the foot may be shaken out.

The web of the shoe is likewise of that thiekness, that when the foot is properly pared, the prominent part of the frog shall lie just within and above its ground surface, so that in the descent of the sole, the frog shall come sufficiently on the ground to enable it to act as a wedge and to expand the quarters, while it is defended from the wear and injury it would reecive, if it came on the ground with the first and full shock of the weight.

The nail-holes are, on the ground side, placel as near the outer edge of the shoe as they can safely be, and brouglit out near the inner edge of the seating. The nails thus take a direction inward, resembling that of the erust itself, and have firmel loold, and the weight of the horse bcing thrown ou a flat surface, contraction is not so likely to be produced.

It is expedient not only that the foot and ground surface of the shoe should be most aceurately level, but that the erust should he exactly smoothed and fitted to the shoc. Much skill and time are necessary to do this perfectly with the drawing-knife. The smith has adopted a method of more quickly and more accurately adapting the shoe to the 
foot. He pares the erust as level as he ean, and then he brings the shoe to a heat somewhat below a red heat, and applies it to the foot, and deteets any little elevations by the deeper eolor of the burned horn. This praetiee has been mueh inveighed against; but it is the abuse, and not the use of the thing which is to be eondemned. If the shoe is not too hot, nor held too long on the foot, an aceuracy of adjustment is thus obtained, which the knife would be long in produeing, or would not produce at all. If, however, the shoe is made to burn its way to its seat, with little or no previous preparation of the foot, the heat must be injurious both to the sensible and insensible parts of the foot.

The heels of the shoe should be examined as to their proper width. Whatever is the eustom of shoeing the horses of dealers, and the too prevalent praetice in the metropolis of giving the foot an open appearance, although the posterior part of it is thereby exposed to injury, nothing is more eertain than that, in the horse destined for road work, the heels, and partienlarly the seat of eorn, ean seareely be too well eovered. Part of the shoe projeeting externally ean be of no possible good, but will prove an oceasional source of misehief, and espeeially in a heavy country. A shoe, the web of which projects inward as far as it ean without touching the frog, affords proteetion to the angle between the bars and the erust.

Of the manner of attaehing the shoe to the foot the owner ean searecly be a competent judge; he ean only take eare that the shoe itself shall not be heavier than the work requires-that, for work a little hard the shoe shall still be light, with a bit of steel welded into the toe-that the nails shall be as small, and as few, and as far from the heels as may be eonsistent witlı the seeurity of the shoe; and that, for light work at least, the shoe shall not be diven on so elosely and firmly as is often done, nor the points of the nails be brought ont so high up as is generally practiced.

Calkins.*-There are few eases in which the use of ealkins (a turning up or elevation of the heel) ean be admissible in the fore-feet, exeept in frosty weather, when it may in some degree prevent unpleasant or dangerous slipping. If, however, ealkins are nsed, they should be placed on both sides. If the outer heel only is raised with the ealkin, as is too often the ease, the weight eannot be thrown evenly on the foot, and undue straining and injury of some part of the foot or of the leg must be the neeessary eonsequenee.

Clips.-These are portions of the upper edge of the shoe, hammered out, and turned up so as to embraee the lower part of the erust and which is usually pared out a little, in order to reeeive the elip. They are very useful, as more seeurely attaehing the shoe to the foot, and relieving the erust from that stress upon the nails which would otherwise be injurious. A elip at the toe is almost neeessary in every draught-horse, and absolutely so in the horse of heavy draught, in order to prevent the shoe from being loosened or torn off by the pressure which is thrown upon the toe in the aet of drawing. A elip on the outside of 
each shoe, at the beginning of the quarters, will give seeurity to it. Clips are likewise neecssary on the shoes of all heavy horses, and of all others who are disposed to stamp, or violently paw with their feet, and thus ineur the danger of displacing the shoe; but they are evils, inasmueh as they press upon the erust as it grows down, and they should only be used when eireumstanees absolutely require them. In the hunter's shoe they are not required at the sides. One at the toe is sufficient.

The Ilinder sloc,-In forming the hiuder shoes, it should be remembered that the hind limbs are the principal instruments in progressiou, and that in every aet of progression, exeept the walk, the toe is the point on which the whole frame of the animal turns, aud from which it is propelled. This part, then, should be strengthened as mueh as possible; and therefore the hinder shoes are made broader at the toe than the fore ones. Another good effect is produced by this-that, the hinder foot being shortened, there is less danger of overreaching, forging, or clinking, and especially if the shoe is wider on the foot surface than on the ground one. The shoc is thus made to slope inward, and is a little within the toe of the crust.

The shape of the hinder foot is somewhat different from that of the fore foot. It is straighter in the quarter's, and the shoe must have the same for'm. For earriage and dranght-lior'ses generally, ealkins may be put on the heels, because the animal will be thus enabled to dig his toe more firmly into the ground, and urge himself forward, and throw his weight into the eollar with greater advantage; but the ealkins must not be too high, and they must be of an equal lieight on eaeh heel, otlierwise, as has been stated with regard to the fore feet, the weight will not be fairly distributed over the foot, and some part of the foot or the leg will naterially suffer. The nails in the hinder shoe may be placed nearer to the heel than in the fore shoe, because, from the comparatively little weight and conenssion thrown on the hinder feet, there is not so much danger of eontraction.

Diflerent Kinds of Shoes. - The shoe must vary in substanee and weight with the kind of foot, and the nature of the work. A weak foot shonld never wear a heavy shoe, nor any foot a shoe that will last longer than a month. ITere, perliaps, we may be permitted to eaution the horseproprietor against having his cattle shod by eontrat, unless he binds his furrier or veterinary surgeon to remove the shocs onee at least in every month; for, if the contractor, by a lieavy shoe, and a little steel, can eause five or six weeks to intervene between the shoeings, he will do so, althongh the feet of the liorse must necessarily suffer. The shoe should never be henvier than the work requires, for an ounce or two in the weight of thic shoe will sadly tell at the end of a hard day's work. This is acknowledged in the lunting-shoe, which is narrower and lighter than that of the hackney, although the foot of the hackney is smaller than that of the hunter. It is more decidedly acknowledged in the racer, who wears a shoe only sutheiently thiek to prevent it from bending when it is used.

The Concave-Seated Shoe.-An illustration is subjoined of a shoewhich is useful and valnable for general purposes. It is employed in many of 


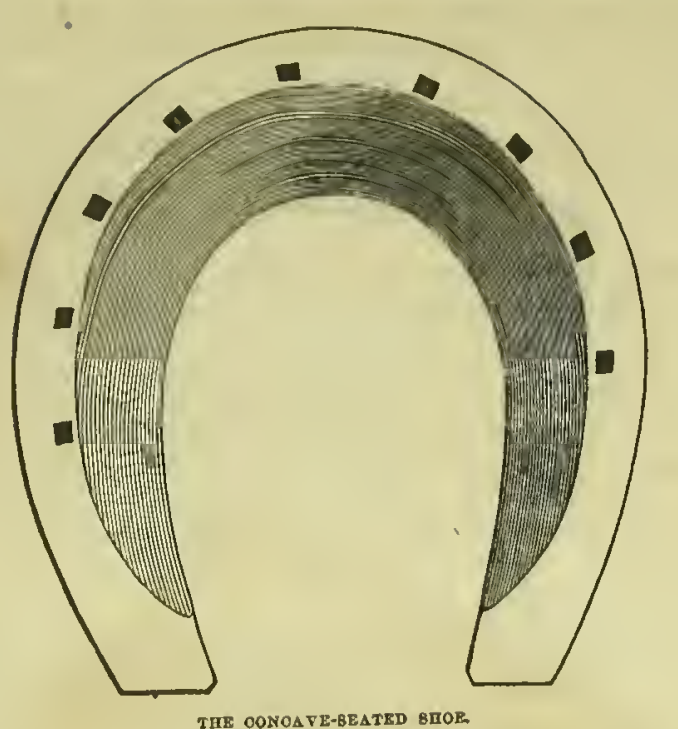

our best forges, and promises gradually to supcrsede the flat and the simple concave shoc, although it must, in many respects, yield to the unilateral shoe.

It presents a perfectly flat surface to the ground, in order to give as many points of bearing as possible, execpt that, on the outer edge, there is a groove or fuller, in which the nail-holes are punehed, so that, sinking into the fuller, their heads project but a little way, and are soon worn down level with the shoc.

The web of this shoe is of the same thickness throughout, from the toe to the heel; and it is sufficiently wide to guard the sole from bruises, and, as much so as the frog will permit, to cover the seat of corn.

On the foot side it is seated. The outer part of it is accurately flat, and of the width of the erust, and designed to support the crust, for by it the whole weight of the horse is sustained.

Toward the heel this flattened part is wider, and occupies the whole breadth of the web, in order to support the heel of the erust and its reflected part, the bar; thus, while it defends the horn included within this angle from injury, it gives that equal pressure from the bar and the erust which is the best preventive against eorns, and a powerful obstacle to contraction.

It is fastened to the foot by nine nails-five on the outside, and four on the inner side of the shoe; those on the outside extending a little farther down toward the heel, because the outside heel is thicker and stronger, and there is more nail-hold; the last nail on the inner quarter being farther from the heel, on account of the weakness of that quarter. For feet not too large, and where moderate work only is required from 
the horse, four nails on the outside and three on the inside will be sufficient; and the last nail, being far from the heels, will allow more expansion there.

The inside part of the web is beveled off, or rendered eoneave, that it may not press upon the sole. Notwithstanding the shoe, the sole does, although to a very ineonsiderable extent, deseend when the foot of the horse is put on the ground. It is unable to bear eonstant or even oeeasional pressure, and if it eame in eontaet with the shoe, the sensible sole between it and the eoffin-bone would be bruised, and lameness would ensue. Many of our horses, from too early and undue work, have the natural coneave sole flattened, and the disposition to deseend, and the degree of deseent, are thereby inereased. The eoneave shoe prevents, even in this ease, the possibility of much injury, beeanse the sole ean never deseend in the degree in which the shoe is or may be beveled. A shoe beveled still farther is neessary to proteet the projeeting or pumieed foot.

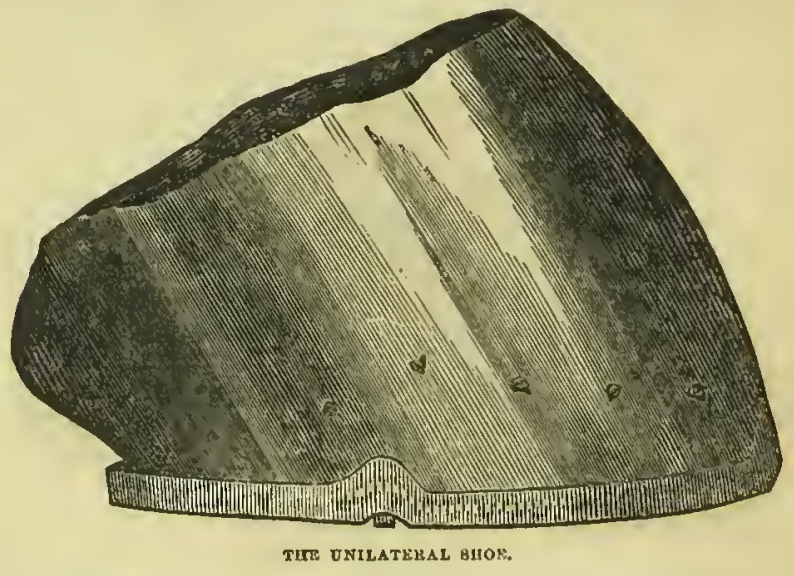

The Inilateral or One-Side Nailed Sloe.-This is a naterial improvement in the art of shoeing, for which we are indebted to Mr. Turner.

What was the state of the foot of the horse a few years ago? An unyielding iron hoof was attaehed to it by four nails in each quarter, and the eonsequenee was, that in nine eases out of ten the foot underwent a very considerable alteration in its form and in its usefulness. Before it had attained its full development-before the animal was five years old, there was, in a great many eases, an evident contraetion of the hoof. There was an alteration in the manner of going. The step was shortened, the sole was hollowed, the frog was diseased, the general elastieity of the foot was destroyed-there was a disorganization of the whole horny eavity, and the value of the horse was materially diminished. What was the grand eause of this? It was the restraint of the shoe. The firm attaehment of it to the foot by nails in eaeh quarter, and the consequent strain to whieh the quarters and every part of the foot were exposed, produced a neeessary tendency to contraction, from whieh 
sprang almost all the maladies to which the foot of the horse is subject.

The unilateral shoe has this great advantage: it is identified with the grand prineiplc of the expansibility of the horse's foot, and of removing or preventing the worst ailments to whieh the foot of the horse is liable. It ean be truly stated of this shoc, that while it affords to the whole organ an iron defense cqual to the common shoe, it permits, what the common shoe never did or can do, the perfect liberty of the foot. We are enabled to present our rcaders with the last improvement of the unilateral shoe.

The preeeding eut gives a view of the outer side of the off or right unilatcral shoc. The respeetive situations of the five nails will be observed; the distance of the last from the heel, and the proper situations at whieh they emerge from the crust. The two elips will likcwise be seen-one in the front of the foot, and the other on the side between the last and second nail.

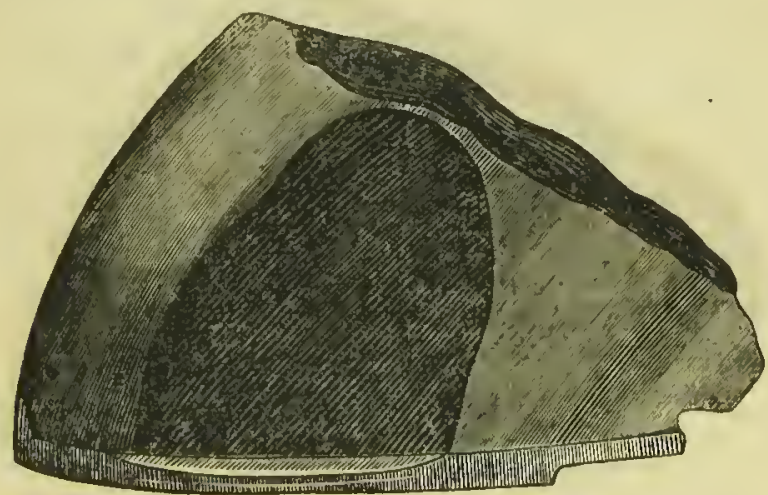

INNEK BIDE OF UNILATERAL BROF

This eut gives a view of the inner side of the unilateral shoe. The two nails near the toe are in the situation in which Mr. Turner dircets that they should be placed, and behind them is no other attaehment, between the shoe and the crust. The portion of the crust which is rasped off from the inner surface of the shoc, is now, we belicve, not often removed from the side of the foot; it has an unpleasant appearanee, and the rasping is somewhit muneeessary. The heel of this shoe exhibits the method which Mr. Turner has adopted, and with eonsiderable sneeess, for the eure of corus; he cuts away a portion of the ground surfaee at the heel, and injurious compression or eoneussion is rendered in a manner impossible.

Therc ean bc no doubt that this one-sided nailing has been exceedingly uscful. It has, in many a ease that threatened a serious termination, restored the elastieity of the foot, and enabled it to clischarge its natural functions. It has also restored to the foot, even iu bad cases, a great deal of its natural formation, and enabled the borse to discharge 
his duty with more ease and pleasure to himself, and greater security to his rider.

The Bar-Shoe.-A bar-shoe is often exceedingly useful. It is the eontinuation of the common shoe round the heels, and by means of it the pressure may be taken off from some tender part of the foot, and thrown on another which is better able to bear it, or more widely and equally diffused over the whole foot. It is principally resorted to in eases of corn, the sent of which it perfectly covers-in pumiced fcet, the soles of which may be thus elevated above the ground and secured from pressure-in sand-craek, when the pressure may be removed from the fissure, and thrown on either side of it, and in thrushes, when the frog is tender, or is become cankered, and requires to be frequently dressed, and the dressing ean by this mcans alone be retained. In these eases the bar-shoe is an exeellent contrivanee, if worn only for one or two shoeings, or as long as the disease requires it to be woln; but it must be left off as soon as it ean be dispensed with. If it is used for the protection of a diseased foot, however it may be chambered and laid off the frog, it will soon beeome flattened upon it; or if the pressure of it is thrown on the frog in order to relieve the sand-crack or the corn, that frog must be very strong and healthy which ean long bear the great and continued pressure. More mischief is often produced in the fiog than previously existed in the part that was relieved. It will be plain that in the nee of the bar-shoe for corn or sand-crack, the erust and the frog should be preeisely on a level; the bar also should be the widest part of the shoc, in order to afford as extended bearing as possible on the frog, and therefore less likely to be injurious. Bar-shoes are evidently not safe in frosty weather. They are never safe when much speed is required from the horse, and they are apt to be wrenched off in a heavy, clayey country.

Tips.-Tips are short shoes reaching only half round the foot, and worn while the horse is at grass, in order to prevent the crust being torn by the oecasional hardness of the ground or the pawing of the animal. 'The quarters at the same time being free, the foot disposed to contract has a ehance of expanding and regaining its natural shape.

The Expanding Shoo.-Our subject would not be complete if we did not describe the supposed expanding shoe, althongh it is now almost entirely out of use. It is either seated or concave like the common shoe, with a joint at the toe, by which the uatural expansion of the foot is said to be permitted, and the injurious consequences of shoeing prevented. There is, however, this radical defeet in the jointed shoe, that the nails oecupy the same sitnation as in the commion shoe, and prevent as they do the gradual expansion of the sides and quarters, and allow only of the linge-like motion at the toe. It is a most imperfeet aceommodation of the expansion of the foot to the action of its internal parts, and even this accommodation is afforded in the slightest possible degree, if it is afforded at all. Either the nails fix the sides and quarter's as in the common shoe, and then the joint at the toe is useless; or if that joint merely opens like a linge, the nail-holes near the toe can no longer correspond with those in the quarters, which aro unequally ex- 
panding at every point. There will be more stress on the crust at these holcs, whicl will not only enlarge them and destroy the fixed attachment of the shoe to the hoof, but often tear away portions of the crust. This shoe, in order to answer the intended purpose, should consist of many joints, running along the sides and quarters, which would make it too complicated and expensive and frail for gencral usc.

While the shoe is to be attached to the foot by nails, we must be content with the concave-seated or unilateral onc, taking carc to place the nail-holes as far from the hecls, and particularly from the inner heel, as the state of the foot and the nature of the work will admit; and where the country is not too heary nor the work too severe, omitting all but two on the inner side of the foot.

Felt or Leather Soles.- When the foot is bruised or inflaned, the concussion or shock produced by the bard contact of the clastic iron with tbe ground gives the animal much pain, and aggravates the injury or discase. A strip of felt or leather is therefore sometimes placed between the scating of the shoc and the crust, which, from its want of clasticity, deadens or matcrially lessens the vibration or shock, and the horse trcads more freely and is evidently relieved. This is a good contrivance while the inflammation or tenderness of the foot continues, but a very bad practice if constantly adopted. The nails cannot be driven so surely or securely when this substance is interposed between the shoc and the foot. The contraction and swelling of the felt or. lcather from the cffect of moisture or dryness will soon render the attacliment of the shoe less firm, there will be too much play upon the nails, the nail-holes will enlarge, and the crust will be broken away.

After wounds or extensive bruises of the sole, or where the sole is thin and flat and tender, it is sometimes covered with a piece of lcather, fitted to the sole and nailed on with the shoe. This may be allowed as a temporary defense of the foot; but there is the same objection to its permanent usc for the insecurity of fistening, and the strain on the crust and the frequent chipping of it. There are also these additional inconveniences, that if the hollow between the sole and the leather is filled with stopping and tow, it is exceedingly difficult to introduce them so evenly and accurately as not to produce partial or injurions pressurc. A few days' work will almost invariably so derange the padding as to canse uncqual pressure. 'The long contact of the sole witb stopping of almost every kind, will produce not a healthy elastic horn, but tliat of a scaly, spongy nature, and if the hollow is not thus filled, gravel and dirt will insinuate themselves and eat into and injure the foot.

Stopping the Fut.-The general habit of stopping the feet requires some consideration. It is a very good or very bad practice, according to circumstanecs. When the sole is flat and thin it should be omitted, cxecpt on the crening before shoeing, and then the application of a little moisture may render the paring of the foot safer and more easy. If it were oftener used it would soften the foot, and not only increase the tendency to descent, but the occasional occurrence of lameness from pebbles or irregularities of the road.

Professor Stewart gives a valuable account of the proper application of stopping: "Farm horses soldom require any stopping. Their feet 
receive suffieient moisture in the fields, or if they do not get much they do not need mueh. Cart-horses used in the town should be stopped onee a week or oftener during winter, and every seeond night in the hot weeks of summer. Groggy horses and all those with high heels, eoneave shocs, or hot and tender feet or an exuberanee of horn, require stopping almost every night. When negleeted, espeeially in dry weather, the sole beeomes hard and rigid, and the horse goes lame or beeomes lame if he were not so before."

One of two substanees or a mixture of both is generally uscu for stopping the feet-elay and eow-dung. The elay nsed alone is too liard and dries too rapidly. Nany horses have been lamed by it. If it is used in the stable, it should always be removed before the horse goes to work. It may perhaps be applied to the feet of heavy dranght-horses, for it will work ont before muels nisehief is done.

Cow dung is softer than the elay, and it has this good property, that it rarely or never becomes too hard or dry. For ordinary work, a mixture of equal parts of elay and eow-dung will be the best applieation; either of them, however, must be applied with a great deal of eantion, where there is any disposition to thrush. Tow used alone or with a small quantity of tar will often be servieeable.

In the better kind of stables a felt pad is frequently used. It keeps the foot eool and moist, and is very useful when the sole has a tendency to become flat. For the eoneave sole tow would be preferable.

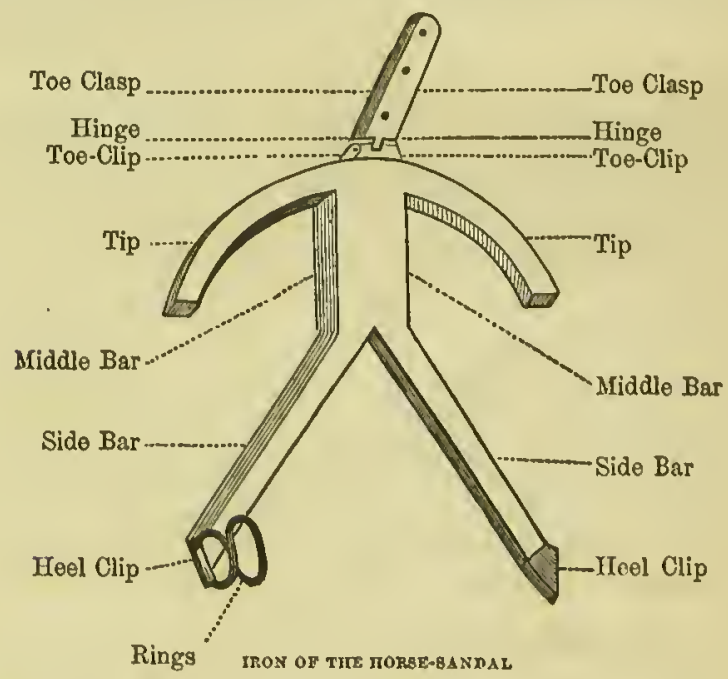

The Sandal.-The shoe is sometimes displaeed when the horse is going at an ordinary paee, and more frequently during hunting; and no person who is a sportsman needs to be told in what a vexatious predieament every one feols bimself who happens to loose a shoe in the middlo of a ehase. 


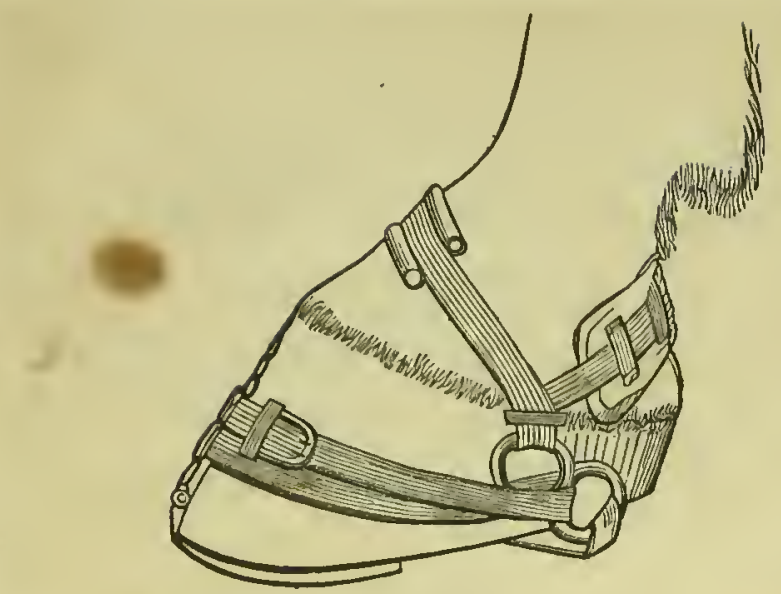

TIE BANDAL.

Mr. Pereivall has invented a sandal which oceupies a very small space in the pocket, ean be buckled on the foot in less than two minutes, and will serve as a perfect substitute for the lost one on the road or in the field, or may be used by the race-horse when traveling from one eourse to another; or may be truly serviceable in eases of diseased feet, that may require at the same time exereise and daily dressing. The above is a sketel of the horse sandal.

From an inspeetion of the ent on the preeding page it will be seen that the iron of the sandal consists of three prineipal parts, to which the others are appendages-which are the tip, so ealled from its resemblance to the horse-shoe of that name; the middle bar, the broad part proceeding baekwilrd from the tip; and the side bars, or branehes of the middle bar, extending to the heels of the hoof. The appendages are, the toeelasp, the part projecting from the front of the tip, and which moves by a hinge upon the toe-clip, which toe-elasp is furnished with two iron loops. The beel-elips are two elips at the heels of the side bars which colrespond to the toc-elip, the latter embracing the toe of the erust whilst the former embraee its heels. Through the heel-elips run the rings, which move and act like a hinge, and are double for the purpose of adinitting both the straps. In the plate, the right ring only is represented; the left being omitted, the better to show the heel-elip. The straps, which are composed of web, consist of a hoof-strap and a heel and coronetstrap.

The hoof-strap is furnished with a buekle, whose office it is to bind the slioe to the hoof; for which purpose it is passed througl the lower rings, and both loops of the shoe, and is made to eneirele the hoof twice.

The heel and coronet-strap are furnished with two pads and two s!iding loops; one, a movable pad, reposes on the heel, to defend that part from the pressure and frietion of the strap; the other, a pad attached 
to the strap near the buckle affords a similar defense, to the coronet in front. The heel-strap runs through the upper rings, crosses the heel, and encireles the coronet; and its office is to keep the hecls of the shoc closely applied to the hoof, and to prevent thern from sliding forward.

In the application of the sandal, the foot is taken up with one hand, and the shoe slipped upon it with the other. With the same hand, the shoe is retained in its place, whilc the foot is gradually let down to rest on the ground. As soon as this is donc, the straps are drawn as tiglit as possiblc, and buckled.

The preceding engraving represents an accurate delineation of the sandal, when properly fastened to the foot.

T0 MANAGE I FALLEN HORSE.- IIorses oceasionally fall from bad riding, or bad shocing, or overreaching, or an awkward way of setting on the saddlc. The head, the ncck, the knees, the back, or the legs will oftenest suffer. It is often difficult to get the animal on his legs again, espccially if he is old and exhausted, or injured by the fall. Thic principal object is, to support the head, and to render it a fixed point from which the muscles may act in supporting the body.

If the horse is in harness, it is seldom that he can rise until he is freed from the shafts and traces. The first thing is to sceure the head, and to keep it down, that he may not beat himself against the ground. Next, the parts of the harness connected with the carriage must be unbuckled - the carriage must then be backed a little way, so that he may have room to risc. If necessary, the traces inust be taken off; and after the horso gets up, he must be steadied a little, until lic collects himself.

TIIE VICES IND DISAGREEABLE OR DANGEROUS LLABTS OF THE HORSE. - The horse has many excellent qualities, but he has likewise defects, and these occasionally amounting to vices. Some of them may be attributed to natural temper, for the human being scarcely discovers more peculiaritics of habit and disposition than does the horse. The majority of them, however, as perhaps in the hmman being, are the consequenecs of a faulty education. Their carly instructor has been ignorant and brutal, and they have become obstinate and vicious. Restiveness.- At the head of all the vices of the horse is restivcuess,
the most annoying and the most dangerous of all. It is the produce of bad temper and worse education; and, like all other habits founded on naturo and stamped by education, it is inveteratc. Whether it appears in the form of kicking, or rearing, plunging, or bolting, or in auy way that threatens danger to the rider or the horse, it rarely admits of
curc.

A determined rider may to a ccrtain cxtent subjugate the animal; or the horse may have lis favorites, or form his attachments, and with some particular person he may be comparatively or perfectly manageanot always sure of him. It is a rulc, that admits of very few exceptions, that ho neither displays his wislom nor cousults his safety, who at-
tempts to conquer a restive horse.

Balking.-Some horses have the habit of balking at first startiug, but 
more from playfulness than desire of miscbief. A moderate application of the whip will usually be effeetual. Otbers, even after starting, exhibit considerable obstinacy and viciousness. This is frequently the effect of bad breaking. Either the shoulder of the horse had been wrung when he was first put to the collar, or he had been foolishly aceustomed to be started in the break up-hill, and, therefore, all his work coming upon him at onec, he gradually aequired this dangerous babit.

A hasty and passionate breaker will often makc a really good-tempered young holse an inveterate balker. Every young horse is at first shy of the collar. If he is too quickly forced to throw bis weight into it, he will possibly take a dislike to it, that will occasionally show itself in the forn of balking as long as he lives. The judieious horse-breaker will resort to no severity, even if the colt should go out several times without even touching the collar. The example of his companion will ultimately induee him to take it voluntarily and effectually.

A large and heavy stone should be put behind the wheel before starting, when the horse, finding it mole diflicult to back than to go forward, will gradually forget this unpleasant trick. It will likewise be of advantage, as often as it can be managed, so to start that the horse will have to back up-hill. The diffieulty of accomplishing this will soon make him readily go forward. A little coaxing, or leading, or moderate flagellation will assist in accomplishing the cure.

When, however, a horse, thinking he bas had enough of wolk, or has been improperly checked or eorrected, or beginning to feel the painful pressure of the collar, swerves, and balks, and backs, it is a inore serious matter. Persuasion should first be tried; and, afterward, reasonable coercion, but no eruelty: for the brutality which is often exercised to compel a balking horse to throw himself habitually into tbe eollar, never yet accomplished the purpose. The horse may, perhaps, be whipped into motion; but if he has once begun to balk, he will have recourse to it again whenever any cireumstance displeases or annoys bim, and the habit will be so rapidly and completely formed, that he will become insensible to all severity.

Sometimes a borse not often accustomed to balk betrays a reluetance to move, or a determination not to move. Before resorting to severity, the eause, if practicable, should be aseertained. The liorse may be over-taxed, his withers may be wrung, or lie may be insupportably galled or pained by the harness. These things should be examined into, and, if possible, reetified; for, under such eireumstanees, cruelty niay produce obstimaey and vice, but not willing obedience.

They who are accustomed to horses know what secmingly trivial circumstanees occasionally produce this viec. A horse whose shoulders are raw, or have frequently been so, will not start with a cold collar. When the collar has aequired the warmtb of the parts on which it presses, the animal will go without reluetanee. Some determined balkers have been reformed by constantly wearing a false collar, or strip of clotb round the shoulders, so that tbe coldness of the usual collar should never be felt; and others have been eured of tho habit by keeping tlie collar on night aud day, for tle animal is not able to lic 
down completely at full length, which the tired horse is always glad to do. When a horse balks, not at starting, but while doing his work, it has sometimes been useful to line the collar with cloth instead of leather; the perspiration is readily absorbed, the substanee which presses on the shonlder is softer, and it may be far more accurately eased off at a tender place.

Biting.- This is either the consequence of natural ferocity, or a habit acquirel from the foolish and teasing play of grooms and stable-linys. When a horse is tickled and pinched by thouglitless and mischicrons yontlis, he will first pretend to bite his tormentors; by degrees he will proceed farther, and actually bite thein, and very soon after that, he will be the first to ehallenge to the combat, and witlout, provocation, scize some opportunity to gripe the incautions tormentor. At length, as the love of mischicf is a propensity too easily acquired, this wal, half playtul and half in earmest, becomes habitual to him, and degenerates into absolute viciousuess.

It is seldom that any thing can be done in the way of cure. Kindness will aggravate the evil, and no degree of severity will correct it. "I lave seen," says Professor Stewart, "biters punished until they trembled in every joint, and were ready to drop, but have never in any case known them cured by this treatment, or by any other. The lash is forgotten in an lour, and the horse is as ready and determined to repeat the offense as before. He appears unable to resist the temptation, and in its worst form biting is a species of insanity."

Prevention, however is in the power of every proprietor of horses. While lue insists on gentle and humane treatinent of his cattle, he should systematieally forbid this horse-play.

Getting the Cheek of the Bit into the Month.-Some horses that are disposed to be mischievous try to do this and are very expert at it. They soon find what advantage it gives them over their driver, who by this mancuver loses almost all command. Harsh treatment is here completely out of the question. All that can be done, is, by some inechanical contrivance to render the thing difficult or inpossible, and this may be managed by fastening a round piece of leather on the inside of the clicek of the bit.

Hicking.-This, as a vice, is another consequence of the culpable habit of grooms and stable-boys of teasing the horse. That which is at first an indication of annoyance at the pinching and tickling of the groom, and without any design to injure, gradnally becomes the expression of anger and the effort to do misclief. The horse, likewise, too soon recognizes the least appearance of timidity, and takes advantage of the discovery, and he cannot be justified who keejs a kicking horse in his stable.

Some horses acquire, from mere irritability and fidgetiness, a habit of kicking at the stall or the bail, and particularly at night. The neighbor:ing lorses are disturbed, and the kickel gets swelled hocks, or some more serions injury. This is also a liabit rery difficult to correct if suffiered to become established. Mares are far more subject to it than horses.

Before the habit is inveterately established, a thorn bush or a piece 
of furze fastened against the partition or post will sometimes effect a cure. When the horse finds that he is pretty severely pricked, he will not long continue to punish himself. In confirmed cases it may be necessary to have recourse to the log, but the legs are often not a little bruised by it. A rather long and heavy piece of wood attached to a chain has been buekled above the hock, so as to reach about half-way down the leg. When the horse attempts to kick violently, his leg will receive a severe blow: this, and the repetition of it may, after a time, teach him to be quiet.

A much more serious vice is kicking in harness. From the least annoyance about the rump or quarters, some horses will kick at a most violent rate, and destroy the bottom of the chaise, and cndanger the limbs of the driver. 'l'hose that are fidgety in the stable are most apt to do this. If the reins shonld perchance get under the tail, the violenee of the kicker will often be most outrageous ; and while the animal presses down his tail so tightly that it is almost inpossible to cxtricate the reins, he continues to plunge until he has demolished every thing behind him.

This is a vice standing foremost in point of danger, and which no treatment will always conquer. It will be altogether in vain to try coereion. If the shafts are very strong and without flaw, or if they are plated with iron underneath, and a stout kicking-strap resorted to which will barely allow the horse the proper use of his hind limbs in progression, but not permit him to raise them sufficiently for the purpose of kicking, he may be prevented from doing mischicf; or, if he is harnessed to a heavy eart, and thus confined, his efforts to lash out will be restrained: but it is frequently a very unpleasant thing to witness these attempt, though ineffectual, to demolish the vehicle, for the shafts or the kicking-strap may possibly break, and extreme danger may ensne. A horse that has once begun to kick, whatever may have been the original cause of it, can never be depended upon again, and he will be very unwise who ventures behind him. The man, however, who must come within reach of a kicker should eome as elose to him as possible. The blow may thus become a push, and seldom is injurions.*

Unsteadiuess while being Mlountel.- When this merely amounts to eagerness to start - very uupleasant, indeed, at times, for many a rider has been thrown from his scat before he was fairly fixed in it-it nay be renedied by an active and good horseman. We have known many iustances in which, while the clderly, and inactive and fearful man has been making more than one ineffectual attempt to vault into the saddle, the horse has been daneing about to his amoyanee and danger; but the aninal had no sooner been transferred to the management of a younger and nore agile rider than he became perfectly subdued. Severity will here, more decidedly than in any other case, do harm. The rider should be fearless-he should carelessly and confidently approach the horse, mount at the first effort, and then restrain him for a while; patting him, and not suffering him to proeeed until he becomes perfectly quiet.

* See Rarey's Method of eorrecting this and other vices, at pago 35. 
Horses of this kind should not be too highly fed, and should have suffieient daily exereise.

When the difficulty of mounting arises, not from eagerness to start, but unwillingness to be ridden, the sooner that horse is disposed of the better. He may be conquered by a skillful and determined horseman; but even he will not suceed withont frequent and dangerous contests that will mar all the pleasure of the ride.

Rearing.-This sometimes results fiom playfulness, carried indeed to an unpleasant and dangerous extent; but it is oftener a desperate and occasionally successful effort to unhorse the rider, and consequently a viee. The horse that has twice dceidedly and dangerously reared, should never be trusted again, unless, indeed, it was the fault of the rider, who had been using a deep eurb and a sharp bit. Some of the best horses will eontend against these, and then rearing may be immediately and permanently cured by using a snaftle-bridle alone.

The horse-breaker's remedy, that of pulling the horse backward on a soft pieee of ground, should be praeticed by reckless and brutal fellows alone. Many horses have been injured in the spine, and others have broken their necks, by being thus suddenly pulled over; while even the fellow who fears no danger, is not always able to extricate himself from the falling horse. If rearing proeeds from viee, and is unprovoked by the bruising and laceration of the month, it fully partakes of the inveteraey which attends the other divisions of restiveness.

Rumning Away. - Some headstrong horses will oceasionally endeavor to bolt with the best rider. Others with their wonted sagacity endeavor thus to dislodge the tinil or unskillful one. Some are hard to hold, or bolt only during the excitement of the chasc; others will run away, prompted by a vieious propensity alone. There is no certain eure here. 'The method which aftords any probability of sueeess is, to ride such a horse with a strong curb and sharp bit; to have him always firnly in hand; and, if he will run away, and the place will admit of it, to give him (sparing neither eurb, whip, nor spur) a great deal more running than he likes.

Vicious to Clenn.-It would scarcely be credited to what an extent this exists in some horses that are otherwise perfectly quiet. It is only at great hazard that they ean be eleansed at all. The origin of this is probably some maltreatment. There is, however, a grent differenee in the sensibility of the skin in different horses. Some seem as if they eould searcely be made to feel the whip, while others cannot bear a fly to light on them without an expression of annoyance. In young horses the skin is peculiarly delicate. If they have been curried with a broken coinb, or liarlly rubbed with an uneven brush, the recollection of the torture they have felt makes them impatient, and even vicions, during every sueceeding operation of the kind. Many grooms, likewise, seem to delight in produeing these exhibitions of uneasiness and vico; although, when they are carried a little too far, and at the hazarel of the limbs of the groom, the animals that have been alnost tutored into these expressions of imitation are brutally kieked and punished.

This, however, is a viee that may be conquered. If the horse is dressed with a lighter hand, and wisped rather than brushed, and the 
places where the skin is most sensitive are avoided as much as thorough eleanliness will allow, he will gradually lose the recolleetion of forner ill-treatument, and become tractable and quict.

Vicious to Shoc.-The correetion of this is more peeuliarly the business of the smith; yet the master slould diligently eoneern himselt with it, for it is oftener the eonsequenee of injudieions or bad usage than of natural vice. It may be expeeted that there will be some difficuliy in shocing a horse for the first few times. It is an operation that gives him a little nneasiness. The inan to whom he is most aeenstomed should go with him to the forge; and if another and steady horse is shod betore him, he may be indueed more readily to submit. It eannot be denied that, after the habit of resisting this neeessany operation is formed, foree inay be sometimes necessary to reduec our rebellions servant to obedience; but we unhesitatingly affirm that the inajority of horses vicious to shoe are rendered so by harsh nsage, and by the pain of correction being added to the uneasiness of shoeing. It should be a rule in every forge tliat no smith should be permitted to strike a horse, mneh less to twiteh or to gag him, without the master-farrier's order; and that a young horse should never be twitehed or struck. There are few horses that may not be gradually rendered manageable for this purpose by mildness and firmness in the operator. They will soon nuderstand that no harm is meant, and they will not forget their usual liabit of obedience; but if the remembranee of eorporal punishment is commeted with shoeing, they will always be fidgety, and oecasionally dangerous.

Switlowing Without Grinding.-Horses have many unpleasant habits in the stable and on the road, which eannot be said to amount to viec, but whijeh materially lessen their value.

Some greedy horses habitually swallow their grain without properly grinding it, and the power of digestion not being arlequate to the dissolving of the lusk, 110 nutriment is extracted, and the oats are roided whole. This is partienlarly the ease when horses of unequal appetite feed from the same inanger. The greedy one, in lis eagerness to get more than his share, bolts a portion of his grain whole. If the farmer, without considerable ineonvenienec, eould eontrive that every horse shall have his separate division of the manger, the one of sinaller appetite and slower feed would have the opportunity of grinding at his leisure, without the fear of the greater share being stolen by his neighbor.

Some horses, however, are naturally greedy feeders, and will not, even when alone, allow themselves time to ehew or grind their grain. In eonsequence of this they earry but little flesh, and are not equal to severe work. If the rack was supplied with hay when the grain was put into the manger, they will continue to eat on, and their stomaehs will beeone distended with half-ehewed and indigestihle food. In eonsequenee of this they will be incapable of eonsiderable exertion for at long time after feeding, and, oceasionally, dangerous symptoms of staggers will oecur.

Tlie remedy is, not to let such liorses fast too long. The nosebag should be the companion of every considerable journey. The food 
should likcwise be of such a nature that it cannot be rapidly bolted. Chaff shonld be plentifully unixed with the grain, and, in some cases, and especially in horses of slow work, it should, witl the grain, constitute the wholc of the food. "This will be treated on more at large under the article "Feeding."

In every case of this kind the tccth should be carefully examined. Some of them may be unduly lengthened, particularly the first of the grinders; or they may bc ragged at the edges, and may abrade and wound the check. In the first place the horse cannot properly masticate his food; in the latter he will not; for these animals, as too often happens in sore-throat, would rather starve than put themselves to much pain.

Crib-Biting.-This is a very unpleasant habit, and a considcrable defect, although not so serious a one as somc liave represented. The horse lays hold of the-manger with his tceth, violcntly extends his neck, and then, after some convulsive action of the throat, a slight grunting is licard, accompanied by a sucking or drawing in of air. It is not an effort at simplc eructation, arising from indigestion. It is the inlaalation of air. It is that which takes place with all kinds of diety and when the stomach is empty as well as when it is full.

The effects of crib-biting are plain cnough. The teetl arc injured and worn away, and that, in an old horse, to a very scrions degree. A considerable quantity of grain is often lost, for the horse will fiequently crib with his moutl full of it, and the greatcr part will fall over the edge of the manger. Much saliva escapes while the manger is thus forcibly held, the loss of which must be of scrious detriment in impairing the digestion. The crib-biting horse is notoriously more subject to colic than other horses, and to a species difficult of treatment and frequently dangcrous. Althongh many a crib-biter is stout and strong, and capable of all ordinary work, these horses do not generally carry so much flesh as others, and have not their endurance. On these accounts crib-biting has very properly been decided to be unsoundness. We must not look to the state of the disease at the time of purchase. The question is, does it exist at all? A case was tricd beforc Lord Tcnterden, and thus decided: "a horse with crib-biting is nnsound."

It is one of those tricks which are cxcecdingly contagious. Every companion of a crib-biter in the same stables is likely to acquire the habit, and it is the most inveterate of all habits. The edge of the manger will in vain be lined with iron, or with sheep-skin, or with sheep-skin covered with tar ol alocs, or any other uupleasant substance. In defiance of the annoyance which thesc may occasion, the horse will persist in the attack on his manger. A strap buckled tightly round the neck, by coinpressing the wind-pipe, is the best means of preventing the possibility of this triek; but the strap must be constantly worn, and its pressure is too apt to producc a worse affection, viz., an in ritation in the wind-pipe, which terminates in roaring.

Sonc have rccommended turning out for five or six montlis; but this has never succeded except with a young horse, and then rarely. The old crib-biter will employ the gatc for the same purpose as the edgc of his manger, and we have often secn him galloping across a field for tho 
mere object of baving a gripe at a rail. Medicine will be altogether thrown away in this case.

The only remedy is a muzzle, with bars across the bottom; sufficiently widc to enable the animal to pick up his corlu and to pull his hay, but not to grasp the edge of the manger. If this is worn for a considerable period, the horse may be tired of attempting that which he cannot accomplisl, and for a while forget the babit, but in a majority of cases, the desire of crib-biting will return with the power of gratifying it.

The causes of crib-biting are varions, and some of them beyond the control of the proprietor of the liorse. It is often the result of imitation; but it is more frequently the consequence of idleness. Tbe high fed and spirited horse must be in mischief if he is not insefully employed. Sonctimes, but we believe not often, it is produced by partial starvation, whether in a bad straw-yard, or from unpalatable food. An occasional causc of crib-biting is the frequent custom of grooms, even when the weather is not severe, of dressing them in the stable. The horse either catches at the edge of the manger, ol at that of the partition on each side, if he has been turned, and thus he forms the habit of laying hold of these substances on evcry occasion.

Wind-Sucking,-This bears a elose analogy to erib-biting. It arises from the same causes; the same purpose is accomplished; and the same results follow. The horse stands witl his neck bent; his head drawn inward; his lips alternately a little opened and then closed, and a noisc is heard as if he were sucking. If we may judge from the same comparative want of condition and the flatulence which we have described under the last head, either some portion of wind enters the stomach, or there is an injurious loss of saliva. 'Tlis diminishes the value of the horse almost as much as crib-biting; it is as contagious, and it is as inveterate. The only remedies, and they will seldom avail, are tying the head up, except when the horse is feeding, or putting on a muzzle with sharp spikes toward the neek, and whieh will priek him whenever he attempts to roin his head in for the purpose of wind-sucking.

Not Lying Down.-It not uncommonly happens that a horse will seldom or never lie down in the stable. He sometimes continues in apparent good health, and feeds and works well; but generally his legs swell, or he becones fatigued sooner than another horse. If it is impossible to let lim loose in the saddle, or to put lim into a spare box, we know not what is to be done. No means, gentlc or crnel, will force bim to lie down. The seeret is that he is tied up, and either has never dared to lie down through fear of the confinement of the lialter, or lie has been east in the night and severely injured. If he can be suffered to range the stable, or have a comfortable box in whieh he may be loose, he will usually lie down the first night. Sounc few horses, however, will lie down in the stable, and not in a loose box. A fresh, well-made bed, will generally tempt the tired-out horse to refresh himself with slecp.

Grerrach,-This unpleasant noise, known also by the term "click ing," arises from the toe of the hind-foot knocking against the shoe of the fore-foot. 
If the animal is young, the action of the horse may be materially improved; otherwise nothing ean be done, except to keep the toe of the hind foot as short and as round as it can safely be, and to bevel off and round the toe of the shoe, like that which has been worn off br a stumbling horse, and perhaps, to lower the heel of the fore-foot a little.

Pawing,--Some hot and irritable horses are restless even in the stablc, and paw frequently and violently. Their litter is destroyed, the floor of the stable broken up, the shoes worn out, the feet bruised, and the legs somctines sprained. If this habit does not exist to any great extent, yet the stable never looks well. Shackles are the only remedy, with a chain suffieiently long to cnable the horse to shift his posture, or more in his stall; but these must be taken off at night, otherwise the animal will seldom lie down. Except, however, the liorse possesses peeuliar value, it will be better to dispose of him at oncc, than to submit to the danger and inconvenience that he may oceasion.

quidting,- A horse will sometimes partly chew his hay and snffer it to drop from his mouth. If this does not procecd from irregular teeth, which it will be the business of the veterinary surgeon to rasp down, it will be found to be comneeted with sore-throat, and then the horse will exhibit some other symptoms of indisposition, and particularly the swallowing of water will be accompanied by a peculiar gulping effort. In this case the disease (catarrh with sore-throat) must be attaeked, and the quidding will cease.

Rolling,-This is a very pleasant and perfectly safe amusement for a horse at grass, but cannot be indulged in the stable without the chance of his being dangerously entangled with the collar-rein (halter) and being cast. Yet, althongh the horse is cast and bruised, and halfstrangled, he will roll again on the following night and continue to do so as long as he lives. The only remedy is not a very pleasant one for the lorse, nor always quite safe; yet it must be had jecourse to, if the habit of rolling is invetcratc. "The horse," says Mr. Castley, "should be ticd with length enongh of halter to lie down, but not to allow of his head resting on the ground; becanse, in order to roll over, a horse is obliged to place his licad quite down upon the ground."

Whying.- We have before briefly treated of the cause of this vice, and observed that while it is often the result of cowardice or playfuluess, or want of work, it is at other times the consequence of a defect of sight. It has been remarked, and we believe very truly, that shying is oftener a vice of half or quarter bred horses, than of those who have in them more of the genuine racing blood.

In the treatment of slying, it is of great importance to distinguish between that which is the consequence of defective sight, and what rcsults from fear or newness of oljects, or mere affectation or skittishness. For the first, the nature of which we have cxplained before, every allowance must be made, and cirre must be taken that the fear of correction is not assoeiated with the imagined cxistence of some terifying object. The severe use of the whip and the spur cannot do good here, and are likely to aggravate the vice tenfold. $\Lambda$ word half encouraging and half scolding with a slight pressure of the heel or a slight tonch of 
the spur, will tell the horse that there is nothing to fear, and will give him confidenee in his rider on a futmre occasion.

The slyying from skittishness or affectation is quite a different affair, and inust be eonquered-but how? Severity is altogether out of place. If he is forced into contact with the object by dint of correction, the dread of punishment will afterward be associated with that objeet, and on the next oecasion his startings will be more fiequent and more dangerous. The way to eure him is to go on, turning as little as possible out of the road, giving a liarsh word or two and a gentle touch with the spur, and then taking no more notice of the matter. After a few times, whatever may have been the objeet which he ehose to select as the pretended canse of affright, he will pass it almost without notice.

Under the head Breaking-in we deseribed how the eolt may be cured of the habit of slyying fiom fear or newness of objects; and if he then is aceustomed as much as possible to the objects annong which his serviees will be required, he will not possess this annoying vice when he grows to maturer age.

It is now generally admitted by all riding-masters and colt-breakers, that a great deal more is to be effected by lenient than by harsh treatment. Rewards are found to operate more benefieially than punishments, and therefore the most seientific and practieed riding-inasters adopt methods based upon the former.

Let us not be understood to mean that the animal is to reeeive any eneouragement to shy; for by no other expression can be eharaeterized that erroneous and foolish praetice of patting the horse or "Inaking mueh of him," either just before or during the time he evinces shyness. The former is bad, beeause it draws the attention of the animal to the objeet he dreads; the latter is worse, beeause it fills him with the impression either that the object itself is really terrific, or that he has acted right in shying at it, and ought to do so again.

Whether we are approaching the frighttul object or the horse is actnally shying, "wc should let hin alone," "we should take no notiee whatever of him," neither letting him perceive that we are aware that we are advaneing toward any thing he dislikes, nor do more with him while in the act of shying than is neeessary for due restraint with a steady hand upon the rein. We may depend upon it, that battling on our part will only serve to augment affright and arouse resistance on his, and that the most judicious eourse we ean pursue is to persevere in mild forbearant usage.

Shying on coming ont of the stable is a labit that ean rarely or never be eured. It proeeeds from the remembrance of some ill-usage or liurt which the aninal has reecived in the act of proeeeding from the stable, such as striking his head against a low doorway or entangling the harness.

When the eure, however, is early attempted, it may be so far overeome that it will be unattended with danger or diffienlty. The horse should be bridled when led ont or in. He should be lield short and tight by the head, that he may feel he has not liberty to make a leap, and this of itself is often sufficient to restrain him. Punishment, or a 
threat of punishment, will be highly improper. It is only timid or ligh-spirited lorses that acquire this habit, and rough usage invariably increases their agitation and terror.

Slipping the Collitr or IJalter.-This is a trick at which many horses are so clever, that scarecly a night passes withont their getting loose. It is a very serious habit, for it cnables the horse sometimes to gorge himself with food, to the imninent danger of staggers; or it exposes him, as he wanders about, to be kieked and injured by the other horses, while his restlessness will often keep the whole team awake. If the web of the halter, boing first aecurately fitted to his neek, is suffered to slip ouly one way, or a strap is attached to the halter and bnekled round the neck, but not sufficiently tight to be of serious ineonrenience, the power of slipping the collar will he taken away.

Tripping.- He must be a skillful practitioner or a mere pretender who promises to remedy this habit. If it arises from a heary forehand, and the fore-legs being too inuch under the horse, no one can alter the natural trame of the animal; if it proceeds from tenderness of the foot, grogginess, or old lameness, these ailments are scldom cmed. Also if it is to be traced to habitual citrelessness and idleness, no whipping will rouse the drone. $A$ known stumbler should never be ridden ol driven by any one who values lis safety or his life. A tight hanul or a strong bearing rein are precautions that should not be neglected, althongh they are generally of little avail; for the inveterate stumbler will rarely be able to save himself, and this tight rein may sooner and farther precipitate the rider. If after a trip the horse suddenly starts forwarl, and endcavors to break into a sloort trot or canter, the rider or drirer may be assured that others before him have fruitlessly endeavored to remedy the nuisance.

If the stumbler has the foot kept as short, and the toe pared as elose as safety will permit, and the shoe is rounded at the toe or has that shape given to it which it naturally aequires in a fortnight, from the peculiar aetion of sudh a liorse, the animal may not stumble quite so much; or if the disease which produeed the habit can be alleviated, some trifling good may be done, but in almost every case a stumblel. slioull be got rid of, ol put to slow and heavy work. If the latter altermative is adopted, he may trip as much as lie pleases, for the weiglit of the load and the motion of the other horses will keep him upon his legrs.

Weaving.-This consists in a motion of the head, neck, and borly from side to side, like the sluttle of a weaver passing through the web, and hence the name whieh is given to this peculian and ineessant and unpleasant action. It indicates an impatient, irritable temper and a dislike to the eonfinement of the stable. A liorse that is thus ineessantly on the fret will seldom carry flesh, or be safe to ride or drive. There is no enre for it but the close tying up of the animal, or at least allowing him but one loose rein, except at feeding-time.

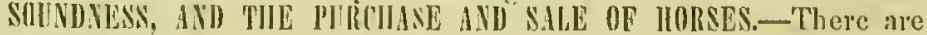
few somres of greater annoyance, both to the purchaser and the seller of the horse, than disputes with rengard to the sounduess of the animal.

That borse is sound in whom there is no disease, and no alteration 
of structure that impairs, or is likely to impair, his natural usefulness. The horse is unsound that labors under disease, or has some alteration of structure which does interfere, or is likely to interfere, with his natural usefulness. The term "natural usefulness" must be borne in mind. One horse may possess great speed, but is soon knoeked up; another will work all day, but cannot be got beyond a snail's pace : a third with a heavy forehand is liable to stumble, and is eontinually putting to liazard the neek of his rider; another, with an irritable constitution and a loose, washy form, loses his appetite and begins to scour if a little extra work is exacted from him. The term unsoundness must not be applied to either of these; it would be opening far too widely a door to disputation and endless wrangling. The buyer ean diseern, or ought to know, whether the form of the horse is that which will render him likely to suit his purpose, and he should try him sufficiently to ascertain his natural strength, endurance, and manner of going. Unsoundness, we repeat, has reference only to discase, or to that alteration of strueture which is connected with, or will ploduce disease, and lessen the usefulness of the animal.

These principles will be best illustrated by a brief eonsideration of the usually supposed appearances or eauses of unsoundness.

Broken Kuees certainly do not constitute unsoundness, after the wounds are healed, unless they interfere with the action of the joint; for the horse may have fallen from mere accident, or through the fault of the rider, without the slightest damage more than the blemish. No person, however, would buy a horse with broken knees, until he has thoronghly tried him, and satisfied himself as to his form and action.

Capped Hocks may be prodnced by lying on an unevenly paved stable, with a seanty supply of litter, or by kicking gencrally, in neither of which cases would they constitute unsoundness, although in the latter they would be an indication of vice; but, in the majority of instances, they are the eonsequence of sprain, or of latent injury of the hoek, and accompanied by enlargement of it, and would constitnte unsoundness. A special warranty should always be taken against capped hocks.

Contration is a considerable deviation from the natural form of the foot, but not necessirily constituting unsoundness. It requires, however, a most carcful examination on the part of the purehaser or veterinary surgeon, in order to aseertain that there is no heat about the quarter, or ossification of the cartilage-that the frog, although diminished in size, is not cliseased-that the loorse does not step sloort and go as if the foot were tender, anrl that there is not the slightest trace of laneness. Unless these eircunstanees, or some of them, are detected, a horse must not be pronounced to be unsound beeause his feet are contracted; for unany horses with strangely contracted feet do not suffer at all in their action. A special warranty, however, should be required where the feet are at all contracted.

Cor'ns manifestly constitute unsoundness. The portion of the foot in which bad corns are situated, will not bear the ordinary pressure of the shoc; and accidental additional pressure from the growing down of the horn, or the introduction of dirt or gravel, will eause serious lameness. 
They render it necessary to wear a thick and heavy shoe, or a bar-shoe. in order to protect the weakened and diseased part; and they are very seldom radically cured. There may be, however, and frequently is, a differenee of opinion as to the aetual existence or eharacter of the corn. They are sometimes, too, so slight that they do not diminish the value of the horse, and will disappear on the horse being shod with ordinary skill and care, even without any alteration in the shoe.

Cough.-This is a disease, and eonseqnently unsoundness. However slight may be its degree, and of whatever short standing it may be, although it may sometimes seareely seem to interfere with the usefulness of the horse, yet a ehange of stabling or slight exposure to wet and cold, or the least over-exertion, may, at other times, cause it to degenerate into many dangerous eomplaints. A horse, therefore, should never be purcliased witl a cough upon hin, without a special warranty ; or if-the congh not being observed-he is purchased under a general warranty, that warranty is thereby broken. It is not law, that a horse may be returned on breach of the warranty. The seller is not bound to take him back, unless he has eontraeted so to do; but he is liable to damages. Lord Ellenborough has completely deeided this natter. "I have always held," said he, "that a warranty of soundness is broken, if the animal, at the time of sale, had any infirmity upon him that rendered him less fit for present service. It is not necessary that the disorder should be permanent or ineurable. While he has a cough, he is unsound, although that may either be temporary or prove mortal."

In deciding on another ease, the same judge said, "I have always held it that a congh is a breach of the warranty. On that understanding I have always acted, and think it quite elear." It was argued on the other hand that two-thirds of the horses in London had coughs, yet still the judge maintained that the cough was a breach of warranty. When it was farther argued that the horse had been hunted the day after the purehase, and the cough might have been increased by this, the reply was singular, but, decisive. "There is no proof that he would have got well if he had not been hunted."

Roaring, Wheezing, Whistling, lligh-blowing, and Grunting, being the result of alteration of structure, or disease in some of the air-passages, and interfering with the perfect freedom of breathing, especially when the horse is put on bis speed, withont doubt eonstitute unsoundness. There are deeisions to the contrary, whieh are now universally admitted to be erroneous. Broken-wind is decidedly still more unsoundness.

Crib-Biting.-Although some learned judges have asserted that cribbiting is simply a trick or bad habit, it must be regarded as unsoundness. This unnatural sueking in of the air must, to a certain degree, injure digestion. It must dispose to colie, and so interfere with the strength, usefulness, and health of the horse. Some erib-biters are good goers, but they probably would have possessed nore enduranee had they not aequired this habit; and it is a fact well established that, as soon as a horse beconjes a crib-biter, he, in nine eases out of ten, loses condition. In its very early stage it may be a nere trick-eonfirmed, it must have produeed morbid deterioration. The wear of the front teeth, and the oecasional breaking of them, make a horso old before 
his time, and sometimes render it difficult or impossible for him to graze, when the state of the animal or the convenience of the owner requires that he sliould be turned out.

Curb constitutes musonndness while it lasts, and perhaps while the swelling remains, although the inflammation may have subsided; for a horse tbat has once thrown ont a curb is, for a while at least, very liable to do so again, to get lame in the sanse place on the slightest extra exertion; or; at all events, he wonld there first fiil on extraordinary exertion. A horse, however, is uot returnable, although he should spring a curb five ninutes after the purchase; for it is done in a moment, and does not necessarily indicate auy previous unsoundness or weakness of the part.

Culting, as rendering a horse liable to serious injury of the legs, and indicating that he is either weak, or has an awkwardness of gait inconsistent with safcty, produces, rather than this, unsoundness. Many horses go lame for a considerable period after cutting themselves severe$\mathrm{ly}$; and others have dropped from the sudden agony, and endangered themselves and their riders. As some doubt, however, exists on this subject, and as it is a very matcrial objection to a horse, cutting, when erident, should liave its serious consequenees prorided against by a special warrautr:

Eularged Gilands. - The enlargement of the glands under the jaw has not been so much considered as it ought to have been in our estimate of the soundness of the horse. Simple catarit will occusionally, and severe affection of the chest will generally, be accompanied by swelling of these glands, whicl does not subside for a considerable time after the cold or fever has apparently been cured. 'I'o slight enlargencuts of the glands under the jaw much attention need not be paid; but if thcy are of considerable size, and especially if they are tender, and the glands at the root of the ear partake of the enlargement, and the menibrane of the nose is redder than it should be, we should hesitate in prononneing that horse to be sound. We must consider the swelling as a symptom of disease.

Enlarged Ilock,-A horse with cnlarged hock is unsomnd, the structure of this complicated joint being so materially affected that, althongh the horse may appear for a considerable time to be eapable of ordinary work, he will occasionally fail even in that, and a few day's' hard work ivill always lane him.

The Eyes. - That inflammation of the eyc of the horse which usually terininates in blindness of one or both eyes, has the peculiar character of receding or disappearing for a time, once or twice, or thrice, before it fully rums its course. The eye, after an attack of inflammation, regains so nearly its former natural brilliancy, that a person even well acquainted witl horses will not alway's recognize the traces of former disease. After a time, however, the inflammation returns, and the result is inevitahle. A horse that has had one attack of this complaint is long: afterwarl unsound, lowever perfect the eye may seem to be, because he carries about with him a disease that will probably again break ont, and eventually destroy the sight. Whether, therefore, he may be rejected or not depends on the possibility of proving an attack of inflammation 
of the eyc prior to the purchase. Next to direct evidence of this are appearanees about the cye, of which the veterinary surgeon at least ought not to be ignorant. They consist elriefly of a puckering of the lids toward the inner corner of one or both cyes - a differenec in the size of the eyes, although perhaps only a slight one, and not discovered except it be looked for-a gloominess of the eyc-a dullness of the iris-a little dullness of the transparent part of the eye generally $\rightarrow$ minute, faint, dusky spot deep in the cye, and generally with little radiations of white limes proceeding from it. If these symptoms, ol the majority of them, existed at the time of purchase, the animal had assuredly been discased before, and was unsound. Starting has been considered as unequivoeal proof. It is usually an indication of defective sight, but it is oceasionally a trick. Comnected, lrowever, with the appearanees just deseribed, it is a very strong corroborative proof?

Lameness, from whatever eause arising, is unsonndness. Howerer temporary it may be, or however obseure, there nust be disease which lessens the utility of the horse, and renders him unsound for the time. So says common sense, but there are contradictory decisions on the ease. "A horse laboring under a temporary injury or" hurt, which is eapable of being specdily eured or removed, is not, according to Chicf Justice Eyre, an unsound horse; and where a warranty is imade that such a borse is sound, it is made without any view to such an injury; nor is a horse so eircumstanced within the meaning of the warranty. To vitiate the warranty, the injury the horse had sustained, or the malady under which be labored, ought to be of a permanent uature, and not snch as may arise from a temporary injury or aecident."

On the contrary, Lord Ellenborough says: "I have always held, and now hold, that a warranty of soundness is broken, if the animal at the time of sale has any infirmity upon him which renders him less fit for present service. It is not neeessary that the disorder slrould be permanent or ineurable. While a horse has a cough he is unsound, although it may either be temporary or may prove nortal. The horse in question having been lame at the time of sale, when he was warranted to be sound, his condition subsequently is no defense to the action.* The decision of Mr. Baron Parke, already referred to, ennfirms this doetrine.

Neurolomy, $-A$ question has arisen how far a horse that has undergone the operation of the division of the nerve of the leg and has recovered from the lameness with which lie was before affected, and stands his work well, may be considered to be sound. Chief Justice Best held such a horse to be unsound, and in our opinion there cannot be a doubt about the matter. The operation of nemrotomy does not remove the disease eansing the lameness, but only the sensation of pain. A horse on whom this operation has been performed may be inproved by it-niny cense to be lane-may go well for many years; but there is no certainty of this, and he is unsound, within onr defunition, unless nature gave the nerve for no useful purpose.

Ossitication of tho Lateral Cartilages constitutes unsoundness, as inter- 
fering with the natural expansion of the foot, and, in liorses of quick work, almost universally producing lameness.

Pumiced-Fot. - When the union between the horny and sensible lamina, or little plates of the foot is weakened, and the coffin-bone is let down, and presses upon the sole, and the sole yields to this unnatural weight, and becomes rounded, and is brought in contact with the ground, and is bruised and injured, that horse must be unsound, and unsound forever, beeause there are no means by which we can raise the eoffin-bone again into its place.

quidding.- - If the mastieation of the food gives pain to the animal, in eonsequence of soreness of the mouth or throat, he will drop it before it is perfectly eliewed. This, as an indication of disease, constitutes unsoundness. Quidling sometimes arises from irregularity in the teeth, which wound the cheek with their sharp edges; or a protruding tooth renders it impossible for the holse to elose his jaws so as to elew his food thorouglily. Quidding is unsoundness for the time; bnt the unsoundness will eease when the teeth are properly filed, or the sorencss or other eause of the imperfect clewing removed.

Quitter is manifestly unsoundness.

Ring-Bone.-Although when the bouy tumor is sinall, and on one side only, there is little or no lameness-and there are a few instanees in which a horse with ring-bone lias worked for many years without its return-yet from the action of the foot, and the stress upon the part, the inflanmation and the formation of bone may acquire a tendeney to spread so rapidly, that we in ust pronounee the slightest enlargement of the pasterns, or around the coronet, to be a cause of unsounduess.

Sand-Crack is manifestly unsoundness. It may, however, occur witl-out the slightest warning, and no horse ean be rejected on account of a sand-crack that lias sprung after purehase. Its usual eause is too great brittleness of the erust of the hoof; but there is no infallible method of detecting this, or the degree in which it must exist in order to constitute unsonndness. When the horn round the bottom of the foot has chipped off so much that only a skillful smith can fasten the shoe without pricking the horse, or eren when there is a tendeney in the horn to elip aud break in a much less degree than this, the horse is unsound, for the brittleness of the crust is a disease of the part, or it is such an altered structure of it as to interfere materially with the usefulness of the animal.

Spavin.--Bone spavin, comprehending in its largest sense every bony tumnor on the hock, is not necessarily unsoundness. If the tumor affeets in the slightest degree the action of the horse, it is unsoundness;-even if it does not, it is seldom safe to prononnee it otherwise than unsoundness. But it may possibly be (like splint in the fore-leg) so situated as to have no tendency to affect the aetion. A veterinary surgeon eonsulted on the purehase will not always rejeet a horse becanse of such a tumor. His evidence on a question of soundness will depend on tho facts. The situation and history of the tnmor may be such as to enable him to give a decisive opinion in a horse going sound, but not often.

Bog or Blood Spavin is unsoundness, because, although it may not be 
productive of lameness at slow work, the rapid and powerful action of the hock in quicker motion will produce permanent, yet perhaps not considerable lameness, which ean scarcely ever be with certainty removed.

Splint.-It depends entirely on the situation of the bony tumor on the shank-bone, whether it is to be eonsidered as unsoundness. If it is not in the neighborhood of any joint, so as to interfere with its action, and if it does not press upon any ligament or tendon, it may be no eause of unsoundness, although it is often very nusightly. In many eases, it may not lessen the capability and value of the animal.

Stringhalt,-This singular and very unpleasant action of the hind-leg is decidedly an unsoundness. It is an irregular communication of nerrous energy to some muscle of the thigh, observable when the horse first comes from the stable, and gradually ceasing on exereise. It has usually been aceompanicd by a inore than common degree of strength and endurance. It must, however, be traced to some morbid alteration of structure or function; and it rarcly or never fails to deteriorate and gradnally wear out the animal.

Thickening of the Back Sinews,-Sufficient attention is not always paid to the fineness of the legs of the horse. If the flexor tendons have been sprained, so as to produce considerable thickening of the cellular substance in which their sheaths are enveloped, they will long afterward, or perhaps always, be liable to sprain, from causes by which they would otherwise be scarcely affectel. The continuance of any considerable thickness around the sheatls of the tendons indicates previous violent sprain. This very thickening will fetter the action of the tendons, and, after much quick work, will oceasionally renew the inflammation and the lameness; therefore such a horse cannot be sound. It requires, however, a little discrimination to distinguish this from the gumminess or roundness of leg peculiar to some breeds. There should be an evident difference between the injured leg and the other.

Thoroughpin, except it is of great sizc, is rarely productive of lameness, and therefore cannot be termed nnsoundness; but as it is the con. sequence of harl work, and now and then does produce lameness, the hock should be most carefully examined, and there should be a special warranty against it.

Thush,- There are varions cases on record of actions on aecount of thrush in horses, and the decisions have been much at variance, or perfectly contradictory. Thirush has not been always considered by legal men as unsoundness. We, however, decidedly so consider it; as being a disease interfering and likely to interfere with the usefulness of the horse. Thrush is inflammation of the lower surface of the inner ol sensible frog-and the secretion or throwing out of pus-alnost invariably accompanied by a slight dlegree of tenderness of the frog itself, or of the heel a little above it, and, if neglected, leading to diminution of the substance of the frog, and separation of the loorn from parts beneath and underrunning, and the production of fungus and eanker, and ultinatcly a disensed state of the foot, destructive of the present and dangerous to the future usefulness of the horse.

Windgalls.-There are few horses perfectly free from windgalls, but 
they do not interfere with the action of the fetloek, or cause lameness, except when they are numerous or large. They constitute unsoundness only when they cause lameness, or are so large and numerous as to render it likely that they will canse it.

In the purchase of a horse, the buyer usually receives, embodied in the receipt, what is termel a warranty. It should be thus expressed:

"Received of A B two hundred dollars for a gray mare, warranted only five years old, sound, free from vice, and quiet to ride or drive.

" $\$ 200$.

"C D."

$\Delta$ receipt including merely the word "warranted" extends only to soundness; "warranted sound" goes no farther; the agc, frecdom fiom vice, and quietness to ride and drive, should be especially named. Tlis warranty comprises every causc of unsoundness that can be detected, or that lurks in the constitution at the time of sale, and to every vicious babit that the animal lias hitherto shown. To establish a breach of warranty, and to be enabled to tender a return of the horse and recover the difference of price, the purchaser must prove that it was unsound or viciously disposed at the time of sale. In case of cough, the horse must have been heard to cough immediately after the purchase, or as he was led home, or as sooll as he had entercd the stable of the purehaser. Coughing, even on the following moruing, will not be sufficient; for it is possible that he might have caught cold by change of stabling. If he is lame, it must be proved to arise from a cause that existed before the animal was in the purchaser's possession. No price will imply a warranty, or be equivalent to one ; there must be an express warranty. A fraud must be proved in the seller, in order that the buyer may be enabled to return the horse or maintain an action for the price. The warranty should be given at the time of sale. $\Lambda$ warranty, or a promise to warrant the horse given at any period antecedent to the sale, is invalid, for horse-flesh is a very perishable commodity, and the constitution and usefulness of the animal may undergo a considerable change in the space of a few days. $\Lambda$ warranty after the sale is invalid, for it is given without any legal consideration. In order to complete the purehase, there must be a transfer of the animal, or a memorandum of agreement, or the payment of the earnest-money. The least sum will suffice for earnest. No verbal promise to buy or to sell is binding without one of these. The inoment either of these is effected, the legal transfer of property or delivery-is marle, and, whatever may happen to the horse, the seller retains, ol is entitled to the money. If the purchaser excreises any act of ownership, by using the animal without leave of the vender, or by having any operation periormed, or any medicine given to him, he makes him his own. The warranty of a servant is considered to be binding on the master.

If the horse should be afterward discovered to have been unsound at the time of warranty, the buyer may tender a return of it, and, if it be not taken back, may bring his action for the priec; but the seller is not bound to rescincl tlie contract, unless he has agreed so to do.

Although there is no legal compulsion to give immediate notice to the seller of the discovered nnsoundness, it will ho better to have it done. 
The animal should then be teidered at the house or stable of the vender. If he refuses to receive him, the animal may be sent to a livery-stable and sold, and au action for the difference in price unay be bronglit. The keep, however, can be recovered only for the time that necessarily intervened between the tender and the determination of the action. It is not legally necessary to tender a retmrn of the horse as soon as the unsoundness is discovered. The animal may be kept for a reasonable time atterward, and even proper medical means used to remove the unsoundness; but courtesy, and indced justice, will require that the noticc should be given as soon as possible. Although it is stated, ou the autlority of Lord Loughborough, that "no length of time clapsed after the sale will alter the nature of a contract originally false," yet it seems to have been once thought it was necessary to the action to give notice of the unsoundness in a reasonable time. The causc of action is ccrtainly complete on breach of the warranty.

It used to be supposed that the buyer had no right to have the horse medically treated, and that he would waive the warranty by doing so. The question, however, would be, has he injured or diminished the value of the horse by this treatment? It will generally be prudent for him to refrain from all inedieal treatment, bevause the mcans adopted, however skillfully cmployed, may have an unfortunate effect, or may be misrepresented by ignorant or interested obscrvers.

The purchaser possibly may like the horse, notwithstanding his discovered defect, and he inay retain, and bring his action for the depreciation in value on account of the unsoundness. Few, however, will do this, because his retaining the horse will cause a suspicion that the defect was of no great consequence, and will give rise to much cavil about the quantum of damages, and, after all, very slight damages will probably be obtained. "I take it to be clear law," says Lord Eldon, "that if a person purchases a horse that is warranted, and it afterward turns out that the horse was unsound at the time of warranty, the buyer may, if he pleases, kecp the horse, and bring an action on the warranty; in which he will havo a light to recover the difference between the value of a sound horse and one with such defects as existed at the time of warranty; or he may return the horse, and bring an action to recover the full money; but, in the latter case, the seller has a right to expect that the horse shall be returned to hin in the same state he was when sold, and not by any means diminished in valuc; for if a person keep a warranted article for any length of time after discovering its defects, and when he returns it, it is in a worse state than it wonld have been if returned immediately alter such discovery, I think the party can have $n$ o defense to an action for the price of the article on the ground of non-compliance with the warranty, but must le left to his action on the warranty to recover the difference in the valuc of the article warranted, and its value when sold.*

Where there is no warauty, an action may be brought on the ground of fraud; but this is very diffieult to be maintained, and not often hazarded. It will be necessary to prove that the dealer knew the defect, 
and that the purchaser was imposed upon by his false representation, or other fraudulent means. If the defect was evident to every eye, the purehaser has 110 remedy-he should have taken more eare; but if a warranty was given, that extends to all unsonndness, palpable or conccaled. Although a person should ignorantly or earelessly buy a blind horse, warranted sound, he may rejeet it-the warranty is his guard, and prevents him fiom so elosely examining the horse as be otherwise would have done; but if he buys a blind horse, thinking him to be sound, and without a warranty, he has no remedy. Every one ought to excreise common cireunspeetion and common sense.

A mian should have a more perfect knowledge of horses than falls to the lot of most, and a perfeet knowledge of the vender too, who ventures to bily a horse without a warranty.

If a person buys a horse warranted sound, and discorering no defeet in him, and, relying on the warranty, resells him, and the unsoundness is discovered by the seeond purehaser, and the horse returned to the first purehaser, or an action commeneed against him, he has his elaim on the first seller, and may demand of him not only the priee of the horse, or the differenee in value, but every expense that may have been incurred.

Absolute exehanges, of one horse for another, or a sum of money being paid in addition by one of the parties, stand on the same ground as simple sales. If there is a warranty on either side, and that is broken, an action may be maintained : if there be no warranty, deceit must be proved.

The trial of horses on sale often learls to dispntes. The law is perfectly elear, but the application of it, as in other matters eonneeted with holse-flesh, attended with glorions uncertainty. The intended purehaser is only liable for damage done to the horse throngh his own misconduct. The seller may put what restrietion he eliooses on the trial, and takes the risks of all aceidents in the fair nse of the horse within such restrictions.

If a liorse from a dealer's stable is galloperl far and fast, it is probable that he will soon show distress; and if he is pushed farther, inflamination and death may ensue. The dealer rarely gets reeompensed for this; nor ought he, as he knows the unfitness of his borse, and may thank himself for permitting snch a trial; and if it should oceur soon after the sale, he runs the risk of having the horse returned, or of an action for its price.

It is proper, however, to put a limit to what has been too frequently asserted from the bench, that a horse warranted sound must be taken as fit for immediate use, and capable of being immerliately put to any fair work the owner ehooses. A hunter honestly warrunted sound is certainly warranted to be in inmediate eondition to follow the lionnds. The mysteries of eondition, as has been show $n$ in a former part of the work, are not sufhciently umraveled.

One of the regulations of the Bazar in King Street was exceedingly fair, both with regard to the previous owner and the purehaser, viz, -

"When a horse, having been warranted sou" shall be returned within the preseribed period, on account of n: ,undness, a certifiente 
from a veterinary surgeon, particularly describing the unsounduess, must accompany the hor'se so returned; when, if it be agreed to by the veterinary surgeon of the establishment, the amount received for the horse shall be immediately paid back; but if the veterinary surgeon of the establishment should not confirm the certificate, then, in order to avoid further dispute, one of the veterinary surgeons of the college shall be ealled in, and his decision shall be final, and the expense of such umpire shall be borne by the party in error."

IISEASES OF TIE MORSE AND TIEEIR TREATMENT.-This work, not being prepared for the veterinary practitioner, but for all horse owners, our aim, therefore, in arranging this part of it will be to make them acquainted with the canses, nature, and remedies of the diseases of the horse, so that they may avoid the causes, detect the cxistence of disease, and themselves apply the remedies, or secure their application by experienced persons.

It may be readily supposed that the animal doomed to the manner of living which every variety of the horse experiences, will be peculiarly exposed to numerous forms of suffering; every natural evil will be aggravated, and nuany new and formidable sourees of pain and deatl will be superadded.

The principal diseases of the hor'se are connected with the eirculatory system. From the state of habitual exeitement in which the animal is kept, in order to enable him to execnte his task, the heart and bloodvessels will often act too impetuonsly; the vital fluid will be hurried along too rapidly, cither through the frame generally, or some partieular part of it, and there will be congestion, aceumnlation of blood in that part, or inflammation, either local or general, distmrbing the functions of some organ, or of the whole frame.

Congestion.-Take a young horse on his first entranee into the stables; feed him somewhat highly, and what is the consequenee? II has swellings of the legs, or inflammation of the joints, or perhaps of the lungs. Take a horse that has lived somew liat above his work, and gallop him to the top of his speed: his nervous system becomes highly excited-the heart beats with fearful rapility-the blood is pmined into the lungs faster than they ean discharge it - the pulmonary ressels become gorged, fatigued, and utterly powerless-the blood, arrested in in its course, becomes viseid, and death speedily ensues. TWe have but one elanee of saving our patient-the instantaneous and copious extraction of blood; and only one means of preventing the recurrenee of this dangerous state; nanely, not suffering too great an accumulation of the sanguineous fluid by over-feeding, and by regular and systematic exercise, which will inure the cireulatory ressels to prompt and efficient action when they are suddenly ealled upon to exert themselves. This is an cxtreme ease, but the eause and the remedy are sufficiently plain.

Again, the brain has funetions of the most important nature to discharge, and more blood flows through it than through any other portion of the frame of equal bulk. In order to prevent this organ from being oppressed by a too great determination of blood to it, the vessels although numcrous, are sinall, and pursue a very circuitons and winding course. If a horse lighly fed and full of blood is suddenly and sliarply 
exercised, the course of the blood is accelerated in every direction, and to the brain among other parts. The vessels that ramify on its surface, or penetrate its snbstance, are completely distended and gorged with it; perliaps they are ruptured, and the eftused blood presses npon the brain; it presses upon the origins of the nerves, on which sensation and motion depend, and the animal suddenly drops powerless. A prompt and copious abstraction of bloor; or, in other words, a diminution of this pressure, can alone save the paticut. IIcre is the nature, the cause, and the treatment of apoplexy.

Sometimes this discase assumes a different form. The horse has not been performing more than his ordinary work, or perhaps he may not have been out of the stable. He is found with his head drooping and his vision impaired. He is staggering about. He falls, and lies half unconscious, or he struggles violently and dangerously. There is the same congestion of blood in the head, the same pressure on the nervous organs, but produced by a different cause. He has been accustomed habitually to overload his stomach, or he was, on the previous day, kept too long withont his food, and then he fell ravenously upon it, and ate until his stomach was completely distended and unable to propel forward its aceumulated contents. Thus distended, its blood-vessels are compressed, and the circulation through them is impeded or altogether suspended. The blood is still foreer on by the heart, and driven in aceumulated quantity to other organs, and to the brain among the rest, and there congestion takes place, as just deseribed, and the animal becomes sleepy, meonscious, and if he is not speedily relieved, he dies. This, too, is apoplexy: the horseman ealls it stomach staggers. Its cause is improper feeding. The division of the hours of labor, and the introduction of the nose-bay, have mueh diminished the frequeney of its ocenrrenee. The remedies are plain: bleeding, physieking, and the removal of the contents of the stomach by incans of a pump contrived for that purpose.

Congestions of other kinds oecasionally present themselves. It is no uneominon thing for the blood to loiter in the complicated vessels of the liver, until the covering of that viseus has burst, and an aceumulation of coagulated black blood has presented itself. This congestion constitutes the swelled legs to which so many horses are subjeet when they stand too long idle in the stable; and it is a souree of wany of the accumulations of serous fluid in various parts of the body, and particularly in the chest, the abdomen, and the brain.

Inflammation is opposed to congestion, as consisting in all active state of the capillary arterial vessels; the blood rushes through them with far greater rapidity than in liealth, from the excited state of the nervous system by which they are supplied.

Inflammation is either local or diffused. It may be confined to one organ, or a particular portion of that organ; it may involve many neighboring ones, or it may be spread over the whole frame. In the latter ease it assumes the name of fever. Fever is general or constitutional inflammation, and it is said to be sympathetic or symptomatic when it can be traced to some local affection or cause, and idiopathic when we eannot so trace it. Tho trinth probably is, that every fever has its local 
cause; but we have not a suffieient knowledge of the animal economy to diseover that eanse.

Inflammation may be eonsidered with referenee to the membranes which it attacks.

The mucous membranes line all the eavities that eommunieate with the external surfaee of the body. There is frequent inflammation of the membrane of the mouth. Blain, or Glysynthrax, is a vesieular enlargement which runs along the side of the tongue. Its eause is unknown. It should be laneed freely and deeply, and some aperient medieine administered. Burbs, or paps, are smaller enlargements, found more in the neighborhood of the bridle of the tongue. They should never be tonehed with any instrument: a little eooling medieine will generally remove them. Lampas is inflammation of the palate, or enlargement of the bar's of the palate. The roof of the mouth may be slightly laneed, or a little aperient medieine administered; but the sensibility of the mouth should never be destroyed by the applieation of the heated iron. Canker and wounds in the mouth, from various eauses, will be best remedied by diluted tineture of myrrh, or a weak solution of alum.

Forcign Bodies in the Gullet may be generally removed by means of the probang used in the hove of eattle; or the cesophagus may be opened, and the obstrueting body taken out.

It is on the mueous membranes that poisons prineipally exert their influenee. The yew is the most frequent vegetable poison. The horse may be saved by timely reeourse to equal parts of vinegar and water ejected into the stomaeh, after the poison has been as mueh as possible removed by means of the stomach-pump. For arsenie or corrosive sublimate there is rarely any antidote.

Spasmotic Colic is too frequently produeed by exposure to eold, the drinking of eold water, or the use of too inueh green food. The horse should be walkerl about, strong frietion used to the belly, and spirit of turpentine given in doses of two ounees, with an ounee ench of laudanum and spirit of nitrous ether, in warm water, ale, or gruel. If the spasm is not soon relieved, the animal should be bled, and injeetions of warm water with a solution of aloes thrown up, if constipation cxists. This spasmodie action of the bowels, when long eontinued, is liable to produee introsusception, or entanylement, of them; and the ease is then hopeless.

Superpurgation often follows the administration of a too strong or inproper close of physic. The torture which it produees will be evident by the agonizel expression of the eountenance, and the frequent looking at the flanks. l'lenty of thin stareh or arrowroot should be given both by the mouth and by injeetion; and, twelre hours having passed without relief being experieneed, ehalk, eateehu, and opium should be added to the gruel.

Worlus in the intestines are not often produetive of mueh misehief, exeept they exist in very great quantities. Small doses of emetie tartar or ealomel, with a little ginger, may be given to the horse half an hour before his first meal, in order to expel the round white worm; it must be worked off with linseed-oil or aloes, and injeetions of linseed-oil or aloes will usually remove the ascarides, or needle-worms. 
The Respiratory Passages are all lined by the mucous membrane. Catarrh, or cold, inflammation of the npper air-passages, should never be long neglected. A few mashes or a little medieine will usually remove it. If it is neglected, and oceasionally in defianec of all treatment, it will rlegenerate into other diseases. The larynx may become the principal seat of inflammation. Larynutis will be shown by extreme diffienlty of breathing, aecompanied by a strange roaring noise, and an evident enlargement and great tenderness of the larynx when felt externally. The windpipe must be opened in such ease, and the best advice will be necessary. Sometimes the subdivisions of the trachea, before or when it first enters the lungs, will be the part affected, and we have bronchitis. This is characterized by a quick and hard breathing, and a peculiar wheezing sound, with the coughing up of mueus. Here, too, decisive neasures must be adopted, and a skillfnl practitioner employed. His assistanee is equally necessary in distemper, infuenza, and epidemic catarrh, names indicating varieties of the same disease, and the product of atmospheric influence; differing to a certain degree in every season, but in all eliaracterized by intense inflammation of the mucous surfaces, and rapid and utter prostration of strengtll, and in all demanding the abatement of that infiammation, and yet little expenditure of vital poswer.

Cough may degenerate into inflummation of the lungs ; ol this fearful nualady may be developed withont a single premonitory symptom, and prove fatal in twenty-four or even in twelve hours. It is mostly characterized by deathly coldness of the extremities, expansion of the nostril, redness of its lining membrane, siugnlarly anxious countenanee, constant gazing at the ftank, and an mnwillingness to move. $\Lambda$ suecessful treatment of such a ease can be founded only on the most prompt and fearless and decisive measures; the laneet slould be freely used. Counter-irritants should follow as soon as the violenee of the discase is in the slightest degree albated; sedatives nunst sueceed to them; and fortunate will he be who often saves lis patient after all the decisive symptoms of pneumonia are onee developed.

The diseases of the lings liave been reeently earefully investigated, and we are cnabled to deteet three important varieties in the influnmatory affections of the lungs and ehest, viz., congestive inflammation of the lungs, or pulmonary apoplexy-pneumonia, or true inflammation of the lnngs-and pleurisy, or pleuritis. The first eousists in the distention of the small ressels of the lungs with dark venous blood, and is generally produecd by over-exertion, particularly if the animal, when attacked, is not in proper condition for work. The symptoms are rapid lreathing, cold extrenitics, and short duration of the disease, ending eitlier in deatlı or recovery. When death supervencs, the lungs are black. With regard to treatment, bleeding should be adopted if the pulse is distinet as well as rapicl; if not, a diffusible stimulant should first be given and bleeding should follow.

Trne puennonia is longer in its duration, but the symptons are often obseure at first. There is considerable distress, but there does not appear to be any active pain; and in this respect it unay geucrally be distiuguished fron pleurisy. The pulse is full, strong, and lapid-pain, 
sometimes aente, but varying from time to time, and the blood presenting a considerable quantity of buff, or fibrine. The tendeneies of the rlisease are either the deposition of water in the ehest, or else fibrous thakes, and sometimes both conjoined.

Sometimes pueumonia and pleurisy are eombined together, eausing pleuropneumonia, and then the danger is inereased at the same time, as the symptoms are rendered more obsenre.

Blood-letting is one of the first of our remedial incasures for these diseases, but is ealled for' in a more marked degree in pleurisy than in pneumonia. The pulse, lowever, in both eases must be our guide as to the quantity to be taken; and, as stated in the text, a decided effeet should be obtained. Repetition of bleeding, too, may be had recourse to with greater freedom, in pleurisy than in pneumonia. In the latter disease, we must take eare that we do not shipwreek the vital powers by repeated and too eopious bleeding, or mistake the effeets produced by bleeding for the symptoms of the disease itself. It is only by the conjoint aids of seienee and experienee that these niec diseriminations ean be made; it is therefore the height of folly for the inexperieneed owner to attempt to treat suel eases himself.

When pleurisy and pueumonia are combined, the symptoms, thongh extremely severe, are yet very obscure, and the chanees of suceessful treatment are mueh diminished. The water in the ehest spoken of in the text, is the termination of plemrisy, and becomes fatal in a majority of cases (particularly if, in addition to this serous fluid, flakes of lymph are also thrown ont.) In some cases where water in the ehest has supervened early, and the inflammation has otherwise subsided, relief lias been obtained by tapping.

We have little to add with regard to the treatment of these inflammatory diseases, except that we do not approve of many repeated bleedings. It is rarely the ease that more than one bleeding is desirable, mit this in general should be very eopious. The best guide as to the propriety of bleeding is the strength of the pulse and not its frequeney. If some hours after the first bleeding the pulse is still strong and full, as well as quiek, then bleeding is most probably ealled for again, and more particularly if the blood has exhibited a thiek buffy coat. If the first bleeding has exlibited no buft on the surface, then a repetition of bleeding is rarely demanded. Aloes should be always eseliewed, and diureties should not be continued after twelve drachms, or two ounees of nitre or resin lave been taken. We have also found very good effects from the administration of sinall doses of ealomel and opium, twice a day, two seruples of the former, and one of tle latter, being suffieient for a dose; and we have also found an ounee or two of the spirit of nitrous ether very serviceable in the early stage of the disease, partieularly if the legs and ears are eold.

Among the consequenees of these severe affections of the lungs, are rhronic cough, not always mueh diminishing the usefulness of the horse, but strangely aggravated at times by any fresh accession of eatarrh, and too often degenerating into thick wind, which always materially iuterferes with the speed of the liorse, and in a great proportion of eases terminates in broken wind. It is rare, indeed, that either of these dis- 
eases admits of eure. That obstruetion in some part of the respiratory eanal, which varies in almost every horse, and produees the peculiar sound termed roaring, is also rarely removed. There are as many degrees or intonations of roaring, as there are notes on the gamut; and those notes aseend from piano to forte. This renders it diffieult in some slight eases to decide positively whether a horse is a roarer or not; and good judges may be mistaken. The state of the animal very frequently oeeasions an impediment to an aceurate decision; if he be in very plethorie condition, he will not unfrequently give slight indieations of roaring; but when he is divested of that superabundanee of fat, all the disagreeable symptoms disappear. The usual test of startling the anjInal, is by no means an infallible eriterion, neither is the stethoseope in all eases to be relied upon. 'There is but one positive node of determ. ining the question; the animal being in a proper eondition, he must be riddell and tried in all his paces. With stallions this proof is not often practicable; and unless they are badly affected, it is often impossible to prove that they are roarers.

Glanders, the most destruetive of all the diseases to whieh the horse is exposed, is the consequence of breathing the atmosphere of foul and vitialcd stables. It is the winding up of almost every other disease, and in every stage it is most contagious. Its most prominent symptoms are a small but eonstant diseharge of stieky matter from the nose; an enlargement and induration of the glands beneath and within the lower jaw, on one or both sides, and, before the termination of the disease, ehanerous inflammation of the nostril on the same side with the enlarged gland. Its eontagiousness should never be forgotten, for if a glandered horse is onee introdueed into a stable, almost every jnhabitant of that stable will sooner or later beeome infeeted and die.

If some persons underrate the danger, it is beeanse the disease nay remain unreeognized in the infeeted horse for some months, or even years, and therefore, when it appears, it is attributed to other eauses, or to after-inoculation. No glandered horse should be employed on any farm, nor should a glandered horse be permitted to work on any road, or even to pasture on any field. IIe should be destroyed.

In a well settled ease of glanders it is not worth while, exeept by way of experiment at a veterinary sehool, to attempt any remedies. The ehanees of eure are too remote, and the danger of infeetion too great.

The eontagious nature of glanders is very well known, and not only is it so with regard to the horse, but it is eapable of being ennmunieated to the human being; and, indeed, there liave been very many deaths from this eause, and most horrible deaths they are. It is generally by means of some eut or abrasion which comes in contact with the glandered matter that the infectiou is eommunieated. The ntmost eaution should therefore be exereised by the attendants; and it is most unpardonable to keep glandered horses any length of time for the sake of their work; and we are seareely justified in tampering long with them under the idea of effeeting a eure, when the eases are deejdedly glandered.

The urinary and genital organs are also lined by unueous membranes. The horse is subject to inflammation of the kidners from eating musty 
oats or mow-burnt hay, from exposure to cold, injuries of the loins, and the imprudent use of diureties. Bleeding, physie and counter-irritants over the region of the loins should be had recourse to. Diabetes or profuse staling is diffieult to treat. The inflammation that may exist should first be subdued, and then opinn, eatechn, and the Uva ursi administered. Inflammation of the bladder will be best alleviated by mucilaginous drinks of almost any kind, linsced-gruel taking precedence of all others. Inflammation of the neek of the bladder, evinecd by the frequent and painful discharge of small quantities of mrime will yield only to the abstraction of blood and the exhibition of opium. A eati:eter may be casily passed into the bladdel of the marc and urine evaeuated; but it will require a skillful veterinary surgeon to effect this in the horsc. A stone in the bladder is readily detected by the praetitioner, and may be extracted with comparative ease. 'The slicatl of the penis is often diseased from the presence of eorrosive mueous matter. This may casily be reınoved with warm soap and water.

To the mueous inembrancs belong the conjunctival tunie of the eye; and the diseases of the cye generally may be here considered. A scabby itchiness on the edge of the eyelid may be cured by a diluted nitrated ointment of mercury. Warts should be cut off with the seissors and the roots touched with lunar caustic. Inflamination of the haw sliould be abatcd by the employment of cooling lotions, but that useful defense of the eye should never if possible be remored. Common ophthalmia will yield as readily to cooling applieations as inflanination of the same organ in any other animal; but thele is another species of inflammation, comncncing in the same way as the first, and for a while apparently yielding to treatment, but which ehanges from eye to cye, and returns again and again, until blindness is produced in one or both organs of vision. The most frequent cause is hereditary predisposition. The reader cannot be too often reminded that the qualitics of the sire, goorl or bad, descend, and seareely changed, to his offspring. IIow moon-blindness was first produced no one linows; tut its continuance in our stables is to be traeed to this canse principally, or almost alone; and it pursues its course until cataract is proaneed for which there is no remedy. Gulta serena (palsy of the optic nerve) is sometimcs observed, and many have becn deccived, for the eye retains its perfect transpareney. Here also medieal treatment is of no avail.

The serous menbranes are of great importanee. The brain and spinal marrow with the origins of the nerves are surrounded by them; so are the heart, the lungs, the intestinal canal, and the organs whose office it is to prepare the generative fluid.

Inllammation of the Brain.-Mad-staggers falls under this division. It is inflammation of the meninges or envelopes of the brain, produeed by over-exertion or by any of the eauses of general fever, and it is charactcrized by the wildest delirium. Nothing but the most profuse bloodletting, active purgation and blistering the head will aftord the slightest hope of suecess. Telanus, or locked jaw, is a eonstant spasm of all the voluntary museles, and particularly those of the neck, the spine and the head, arising from the injury of some nervous fibril-that injury spread- 
ing to the origin of the nerve-the brain bccoming affected, and universal and nubroken spasmodic action bcing the result. Bleeding, physicking, blistering the coursc of the spinc, and the administration of opinm in cnormous doscs, will alone give any chance of cnre. Epilepsy is not a frequent discase in the horse, but it seldom admits of curc. It is also very apt to return at the most distant and uncertain intervals. Palsy is the suspension of ncrvous power. It is usually confined to the hinder limbs and sonctimes to one limb only. Blceding, physieking, antimonial medicines, and blistering of the spine are most likely to produee a curc; but they too often utterly fail of success. Rabies, or madncss, is cvidently a discase of the nervous systcm, and once being developed, is altogether withont remedy. The utter destruction of the bittcn part with the lunar canstic soon after the infliction of the wound, will, however, in a great majority of cases, prevent that development.

Foundel.-Founder, when aeute, requires a treatment like that of other inflammations, with such differences as the situation of the disease may suggest.

Blceding is indispensablc, and that to its fullest extent. If the disease is confined to the fore-fcct, four quarts of blood should be taken as soon as possible from the toe of each; carc being taker to open the artery as well as the vein. The feet may likewisc be put into warm water, to quicken the flow of the blood, and increase the quantity abstracted. Poultices of linsecd mcal, made very soft, should cover the whole of thc foot and pastern, and be frequently renewed, which will promote cvaporation from the ncigluboring parts, and possibly throngh the pores of the loof, and by softening and rendcring supple the hoof, will relicve its painfinl pressnre on the swelled and tender parts bencath. More fully to accomplisl this last purpose, the shoe should be removed, the sole parcd as thin as possible, and the crust, and particularly the quarters, wcll rasped. All this must be done gently, and with a great deal of paticnee, for the poor animal can scarcely bear his feet to be meddled with. There uscd to be occasional doubt as to the administration of physic, from fcal of metustasis (shifting) of inflammation which has somctimes occurred, and bcen gencrally fatal. When, however, there is so much danger of losing the patient from the oliginal attaek, we mnst run the risk of the other. Sedative and cooling medicincs should be diligently administcred, consisting of digitalis, nitre, and cinetie tartar.

Cllronic Founder.-This is a specics of founder insidious in its attack, and destructive to the horsc. It is a milder form of the preceding discase. There is lameness, but it is not so sevcre as in the former case. The horse stands as nsual. The crust is warm, and that warmtl is eonstant, but it is not often probably greater than in a state of health. The surcst symptom is the action of the animal. It is dianctrically oppesito to that in the navicular discase. The horse throws as much of his weight as he can on the posterior parts of his feet.

The treatment slould be similar to that recommended for the aeute disease-blood-lctting, poultices, fomcntations, and blisters, and the last much sooncr and much more frequently than in the former disease.

Bog und Blood-Spavin.-Attached to the extremities of most of the 
tendois, and between the tendons and other parts, are little bags containing a mucous substance to cnable the tendons to slide over each other without friction, aud to move casily on the neighboring parts. From violent excreise these vessels are liable to enlarge. Wind galls and thorouglipins arc instances of this. There is one of them on the inside of the hock at its bending. This sometines becomes considerably increased in size, and tlıc enlargement is called a bog-spavin. A vein passes over the bag, which is pressed betwecu the cnlargement and the skin, and the passage of the blood through it is inpeded; the vcin is conscquently distended by the accumulated blond, and the distension rcaches fiom this bag as low down as the next valve. This is called blood-spavin. Blood-spavin, then, is the conscquence of bog-spavin. It very rarcly occurs, and is, in the majority of instances, confounded with bog-spavin.

Blood-spavin does not always causc lameness, except the horse is very hard-worked; but this, as well as bog-spavin, constitutes unsoundness, and materially lessens the valuc of the horse. The proper treatment is, to cndeavor to promotc the absorption of the contents of the bag. This may be attcmpted by pressurc long applied. A bandagc may be contrived to take in the whole of the hock, except its point; and a compress made of folded lincn being placed on the bog-sparin, may confine the principal pressure to that part. It is, howerer, very difficult to adapt a bandage to a joint which admits of such cxtensive motion; thercfore most practitioners apply two or threc successive blisters over the cnlargenent, when it usually disappears. Unfortunatcly, howcrer, it returns if any cxtraordinary cxertion is required from the horsc.

Strallgles.*-This is a discase principally incident to young horsesusually appearing between the fomth and fiftl year, and oftener in the spring thau in any other part of the ycar. It is preceded by cough, and can at first scarcely be distinguishicd from common congl, cxcept that there is more discharge from the nostril, of a ycllowish color, mixed with pus, and generally without smell. There is likewise a considerable discharge of ropy fluid from the month, and greater swelling than usual under the throat. This swelling increases with uncertain rapidity, accompanicd by some fever and disinclination to cat, partly arising from the fever, but more from the pain which the animal feels in the act of mastication. There is considerablc thirst, but after a gulp or two the horse ccases to drink, yet is evidently desirous of continning his dranglit. In the attempt to swallow, and sometimes when not drinking, a convulsive cough comes on, which almost threatcns to suffocate the auimal-and thence, probably the name of the discasc.

The tumor is under the jaw, and about the center of the channcl. It soon fills the whole of the spacc, and is cvidently one uniform body, and may thus be distingnished from glanders, or the cnlarged glands of catarth. In a few day's it becones morc prominent and soft, and evidently contains a fluid. This rapidly increases; the tumor bursts, and a great qnantity of pus is discharged. As soon as the tumor has broken the cough subsides, and the hor'se speclily mends, although some degree

* Usually termed "Horse distemper" in the Unitod States. 
of weakness may hang about him for a considerable time. Few horses, possibly none, escape its attaek; but the disease having passed over, the animal is free from it for the remainder of his life. Catarrh may preeede, or may predispose to, the attaek, and, undoubtedly, the state of the atmospliere has nuch to do with it, for both its prevalenee and its severity are connected with certain seasons of the year and elianges of the weather. There is no preventive for the disease, nor is there any thing contagions about it. Many strange stories are told with regard to this; but the explanation of the matter is, that when several horses in the same form, or in the same neighborhood, have had strangles at the same time, they have been exposed to the same powerful but unknown exciting eause.

As soon as the tumor under the jaw is decidedly apparent, the part should be aetively blistered. From the thiekness of skin, poultiees, fomentations, etc., are of little avail. The blister will also abate the internal inflammation and soreness of the throat, and thus lessen the eough and wheezing.

As soon as the sivelling is soft on its summit, and evidently contains matter, it should be freely and deeply laneed. It is a bad, although frequent praetiee, to suffer the tumor to burst naturally, for a "'irged uleer is formed, very slow to heal and diffienlt of treatment. If the ineision is deep and large enough, no seeond collection of matter will be formed: and that which is already there may be allowed to run out slowly, all pressure with the fingers being avoided. The part should be kept clean, and a little friar's balsam injeeted daily into the wound.

The remainder of the treatinent will depend on the symptoms. If there is much fever, and evident affection of the ehest, and which should carefully be distinguished from the oppression and ehoking oceasioned by the pressure of the tumor, it will be proper to bleed. In the majority of cases, however, bleeding will not only be unneeessary, but injurious. It will delay the suppuration of the tumor, and inerease the subsequent debility. A few eooling medieines, as nitre, emetic tartar, and perhaps digitalis, may be given, as the ease requires. The appetite, or rather the ability to eat, will return with the opening of the abseess. Jran-mashes, ol fresh-eut grass or tares, slould be liberally supplied, whiel will not only afford suffieient nourishment to reeruit the strength of the animal, but keep the bowels genty open. If the weakness is not great, no further medieine will be wanted, exeept a dose of mild physie in order to prevent the swellings or eruptions which sometimessueeed to strangles. In eases of debility, a small quantity of tonic melieine, as chamomile, gentian, or ginger, may be administered.

Poll-Evil. - From the hor'se rubbing and sometimes striking his poll against the lower end of the manger, or hanging back in the stall and bruising the part with the halter-or from the frequent and painful stretehing of the ligaments and muscles by unneessary tight reining, and, oceasionally, from a violent blow on the poll, intammation ensues, and a swelling appears, hot, tender, and painful. It used to be a disease of frequent oceurrence, but it is now, from better treatment of the animal, of comparatively rare occur'rence.

It has been stated that the ligament of the neck passes over the atlas, 
or first bone, without being attached to it, and the seat of inflammation is between the liganient and the bone beneath; and being thus deeply situated, it is serious in its nature and dillieult of treatment.

The first thing to be attempted is to abate the inflammation by bleeding, physic, and the appliention of eold lotions to the part. In a very early period of the ease a blister might have eonsiderable effeet. Strong purgatives should also be employed. By these means the tumor will sometimes be dispersed. This system, however, must not be pursued too far. If the swelling inereases, and the heat and tenderness likewise inerease, matter will form in the tumor; and then our objeet should be to hasten its formation by warm fomentations, poultiees, or stimulating embroeations. As soon as the matter is formed, which may be known by the softness of the tumor, and before it has time to spread around and eat into the neighboring parts, it should be evacuated. Now eomes the whole art of treating poll-evil; the opening into the tumor must be so contrived that all the matter shall run out, and eontinue afterward to run out as quiekly as it is formed, and not eolleet at the bottom of the uleer, irritating and eorroding it. This ean be effeeted by a seton alone. The needle should enter at the top of the tumor, penetrate through its botton, and be brought out at the side of the neek, a little below the abseess. Witlout any thing more than this, except frequent fonentation with warm water, in order to keep the part elean, and to obviate inflammation, poll-evil in its early stage will frequently be eured.

If the uleer has deepened and spread, and tlireatens to eat into the ligaments of the joints of the neek, it may be neeessary to stimulate its surfaee, and perhaps painfully so, in order to bring it to a healthy state, and dispose it to fill up. In extreme eases, somo highly stimulating application may be employed. All measures, however, will be ineffectual unless the pus or matter is, by the use of setons, perfeetly evacuated. The appliention of these setons will require the skill and anatorical knowledge of the veterinary surgeon. In despernte eases, the wound eannot be fuirly exposed to the ation of the eaustie withont the division of the ligament of the neek. This may be effeeted with perfeet safety; for, althougl the liganent is earried on to the oeeipital bone, and some strength is gained by this prolongation of it, the main stress is on the seeond bone; and the head will continue to be supported. 'The divided ligament, also, will soon unite again, and its former usefulness will be restored when the wound is healed.*

* All cooling applications to the poll-evil are uselcss, for when once the swelliug which constitutes the disease has appeared, we have never known it dispersed, but sooner or later it suppurates. It often takes many montlis before the matter rcaches the surface; but the morc complete the suppuration is, the easier it is to eflect a cure. The injury, which generally arises from striking the poll against a low dool. way, is deep-sented, and the surface of the bone is often discased from the beginving.

It must be confessed that the poll-evil is very difficult to cure, a difficulty arising not from the charaster of the injury, but rather from its situation, and the nature of the surroundiog parts. When matter forms in ally situation, it has a tendency to pass downward, and to seek an exit where the least obstacles are oflered to its passage. It consequently forms passages or simuses (pipes) amongst the muscles, and when these are filled the matter points to the surface. This tendency con- 


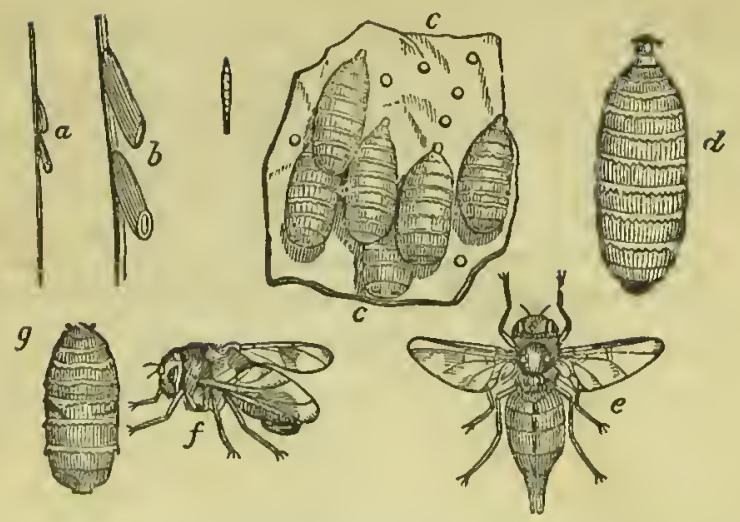

$a$ and $b$, the eggrs of the gar-fly adhering to the hair of tho horse; $c$, the appearance of tho bots on the stomnth, firmly ndhering by their hooked mouths. The ninrks or depressions are seen which are left on the cont of the stomach when the bots are detached from their hold; $d_{d}$ tho bot detaetied; $e$, tho female of the gnd-fly of the horse, prepared to deposit bor eg $g^{3} ; f$, the gad-fly by which the red bots are produced; $\theta$, the sraalier, or rod bot.

Bots.-In the spring and early part of the summer, horses are much troubled by a givb or caterpillar, which crawls ont of the anus, fastens itself under the tail, and scems to cause a great deal of itching or uneasiness. Grooms are sometimes alarmed at the appearanee of these insects. Their history is eurious, and will dispel every fear witl regard to them. We are indebted to Mr. Bracy Clark for almost all we know of the bot.

A spceies of gad-fly, $e$, the otrus equi, is in the latter part of the summer execedingly busy abont the horse. It is observed to be darting with great rapidity toward the linees and sides of the animal. The females are depositing their eggs on the hair, and which adhere to it by means of a glutinous fluid with which they are surrounded ( $a$ and $b$ ). In a few days the eggs are ready to be hatched, and the slightest application of warmth and moisture will liberate the little animals which they contain. The horse in lieking himself touches the egg; it bursts,

timues after an external opening is made, and deep sinuses are formed in various directions, rendering it almost impossible to get a depending opening.

The-absecss slould not be opened till the matter is thoroughly formed, and then a depending opening should be made, through whieh a seton may be passed. The great error frequently made in the treatment of poll-evil is, that these openings are not made half large enough, so that imeh of the pus flows in another direetion, and there forms sinuses. Now, the elief art in the treatment of this disease is to use the bistoury freely, to lay all the sinuses open as much as possible, and to throw thein together; then to make the lower opening extremely large, and as low down as possible-large enough, indeed, for two fingers to be iuserted. If the bone is injured, it will be necessary to apply some eaustie application, in order to cause a healthy slougl. Pressure is found very nseful in keeping the sides of the wound together, and preserving the formation of sinuses. With this view, it has been reeommended to apply a tight eompress, by means of bandages, round the part, but it is extremely ineonvenient to apply them, in consequenee of the windpipe interfering.-Spooner. 
and a small worm escapes, which adheres to the tonguc, and is conveyed with the food into the stomach. There it clings to the cuticular portion of the stomach, $c$, by means of a hook on either side of its mouth; and its hold is so firm and so obstinate, that it inust be broken before it can be detached. It remains there fecding on the inucus of the stomach during the whole of the winter, and until the end of the cnsuing spring; when, having attained a considerable size, $d$, and being destined to undergo a certain transformation, it disengages itself fiom the cuticular coat, is carried into the villous portion of the stomach with the food, passes out of it with the chyme, and is cvacuated with the dung.

The larva, or maggot, seeks shelter in the ground, and buries itself there; it contracts in size, and becomes then a chrysalis, or grub, in which statc it lies inactive for a few weeks, and then, bursting from its confinement, assumes the form of a fly. The female, becoming impregnated, quickly deposits her eggs on those parts of the horse which he is most accustomed to lick, and thus the species is perpetuated.

There are several plain conclusions to be drawn from this history. 'The bots cannot, while they inhabit the stomach of the horse, give the animal any pain, for they lave fastened on the cuticular and insensible coat. They cannot be injurious to the horse, for he enjoys the most perfect health when the cuticular part of his stomach is filled with them, and their presence is not even suspected until they appear at the anus. They cannot be removed by medicine, because they are not in that part of the stomach to which medicine is usually conveyed; and if they were, their montlis are too deeply buried in the mucus for any medicine, that can be safely adıninistered, to affect them; and, last of all, in due course of time they detach themsclves, and come away. Therefore the wise man will leave then to themselves, or content himself with picking them off when they collect under the tail and annoy the animal.

The smaller bot, $f$ and $g$, is not so frequently found.

Wind-Galls. - In the neighborhood of the fetlock there are occasionally found considerable enlargements, oftener on the hind leg than the forc one, which are denominated wind-galls. Between the tendons and other parts, and wherever the tendons are exposed to pressure or friction, and particularly about their extremities, little bags or sacs are placed, containing, and snffering to ooze slnwly from th:en, a nuecus fluid to lubricate (make slippery) the parts. From mndne pressure, and that most frequently caused by violent action and straining of the tendons, or often troin some predisposition about the horse, thesc little sacs are injured. They take on inflammation and sometimes become large and hardened. There are few horses perfectly tree from them. When they first appear, and until the inflammation subsides, they may be accompanied by some degree of laneness; but otherwise, except when they attain a great size, they do not interfere with the action of the animal, or cause any considerable unsoundness. The farriers nsed to supposc that they contained wind-hence their name, wind-galls; and hence the practice of opeuing them, by which dreadful inflammation was often 
produced, and many a valuable horse destroyed. It is not uncommon for wind-galls entirely to disappear in aged liorses.

A slight wind-gall will scarcely be subjected to treatment; but if these tumors are numerous and large, and seem to impede the motion of the limb, they may be attacked first by bandage. The rollers should be of flannel, and soft pads should be placed on each of the enlargements, and bound down tightly upon them. The bandage should also be wetted with the lotion reeommended for sprain of the back sinews. The wind-gall will often diminish or disappear by this treatment, but will too frequently return when the horse is again hardly worked. A blister is a more effectual but too often temporary remedy. Wind-galls will return with the renewal of work. Firing is still more ecrtain, if the tumors are suffieiently large and annoying to justify our having recourse to measures so severe; for it will not only effect the immediate absorption of the fluid and the reduction of the swelling, but by contraeting the skin will act as a permanent bandage, and therefore prevent the reappearance of the tumor. The iodine and mercurial ointments have oeeasionally been used with advantage in the proportion of three parts of the former to two of the latter.

The following formula may be said to contain most of the remedies necessary for the use of the amateur; when disease prevails, the safest plan is to call in the assistance of a veterinary practitioner.

When calomel or emetic tartar is given for the expulsion of worms, it should be mixed in a small portion of bran mash, after fasting the animal five or six lours; two doses given at similar intervals will be most effective. They must be worked off with linseed oil or aloes, after an equivalent lapse of time; and as alkalies neutralize the effects of either of those medicines, soap must be excluded if the form of ball is preferred.

As an external stinulating application for the throat in cases of inflammation arising from cold or other causes, eommon mustard, mixed with water as for the table is an cxcellent remedy, and is cqual if not superior to any of the more eomplicated nostrums.

When cooling remedies are required to the legs, cold water is the best. The introduction of nitre and sal-ammoniae will increase the evaporation; but great eare is requisite to renew such medicated lotions very frequently; because when the refrigerating process is over, they become stimuiants; tinus on ordinir; ocensions cold water constantly applied with very loose linen bandages is to be preferred.

TABLE SHOWING THE PROPORTIONS OF MEDICINES TO BE GIVEN TO HORSTS AT VARIOUS AOES.

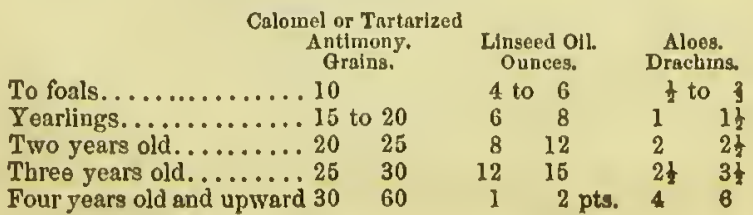


Common Aloctic Purgative.-Aloes fincly powdered, four drachms; hard soap and ginger, each two drachms. Mix and form a ball, varying the proportions aecording to the age and constitution of the horse.

Mloetic Purgative without Soap.-Alocs broken in piees, four draehms; olive oil or lard, one drachm; ginger in powder, two drachms; treacle, one and a half drachms. The aloes and oil, or lard, must be melted in a jar plaeed in a saucepan over the fire, and when nelted, the ginger and treaele are added. The aloes must not be boiled longer than to effect their solution.

Aloetic Alteratives.-Alocs in fine powclers, two drachms; nitre, two drachms; soap, two drachms. Mix and form one ball. To be given daily till a slight action of the bowels is produced.

Antimonial Alterative,-Sulphur and sulphuret of antimony, each two to three drachins. Treacle to form a ball. One of which may be given four, five, or six days in suecession.

The preparation necessary before giving aloetic purges should be very scrupulously attended to. Bran mashes must be libcrally substjtuted for lay during the twenty-four hours previous to giving the ball; and the horse requires to bc walked out during its operation.

MEDICINES FOR THE HORSE-TUEIR ACTION AND DOSES.

\begin{tabular}{|c|c|c|}
\hline NAMES. & ACTION. & bose. \\
\hline  & 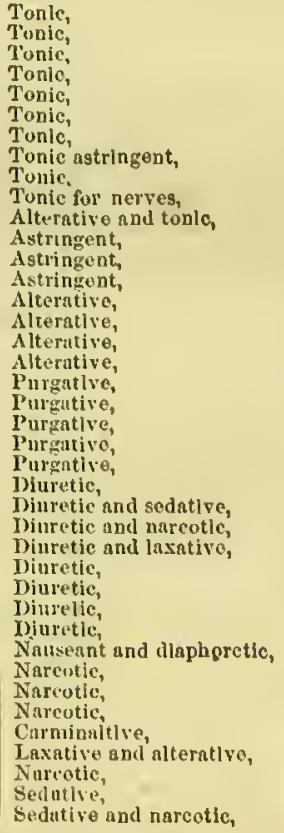 & 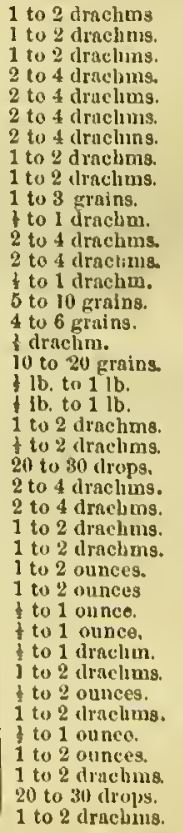 \\
\hline
\end{tabular}

Used extcrnally, murlatic acid, nitrlo acid, sulphurlo acld, and corrosive aubilmate are caustlo lodino is al terative; and augar of lend lis sodative 



\section{CATTLE:}

THE DAIRY AND FAT-PRODUCING BREEDS,

AND

THEIR MANAGEMENT

IN

HEALTH AND DISEASE. 


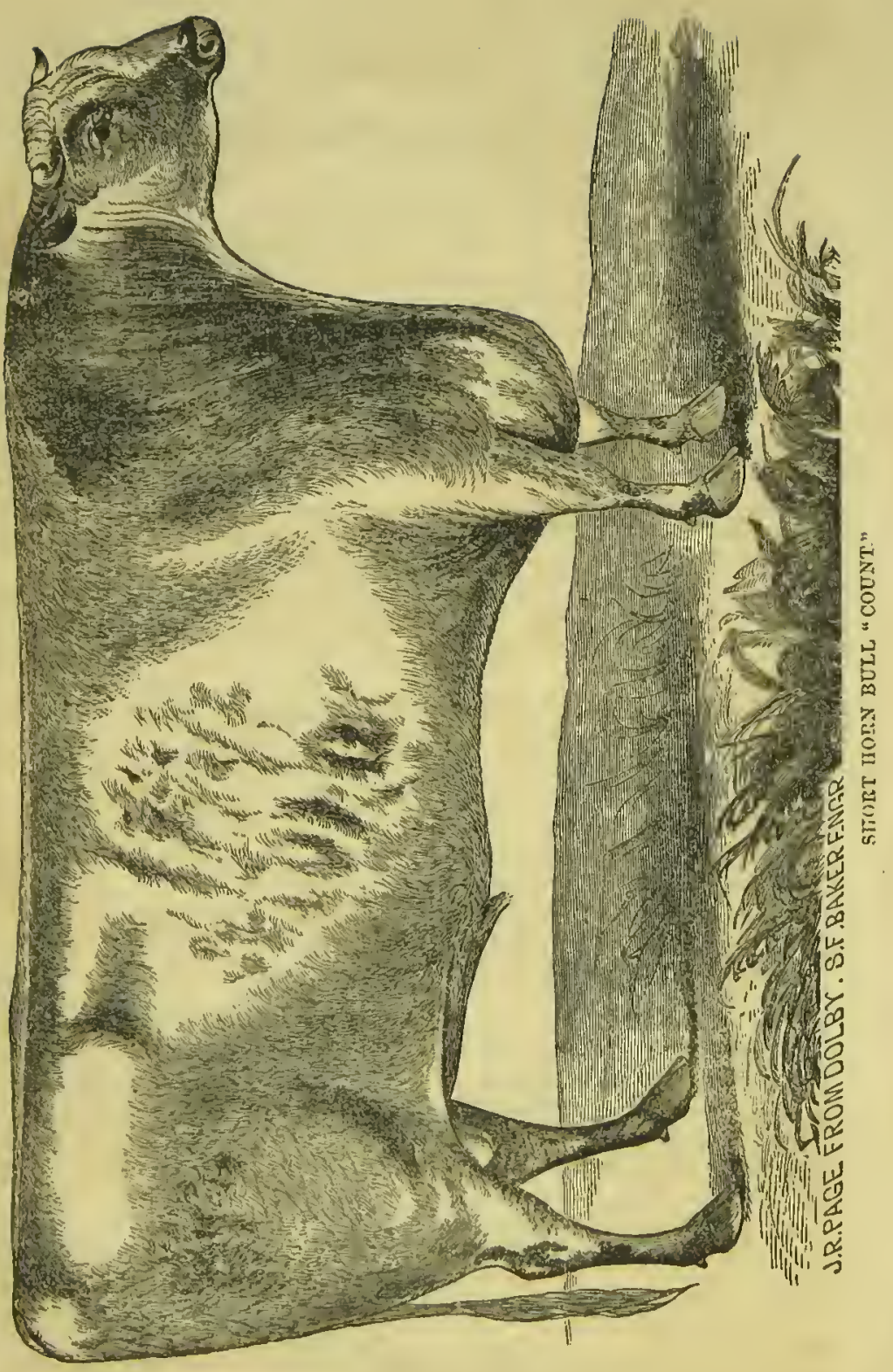




\section{CATTLE :}

\section{THEIR BREEDS, MANAGEMENT, ETC.}

CATTLE, TILIR VALUE.-There is not a race of animals to which the community is on the whole morc indebted, than to cattle. They not only cultivate the land, but afford food of various kinds, in different circumstances of their existcnce; and also, at death, supply very important articles of clothing and utility, and are amongst those amimals to which we owc by far the most of thic comforts and conveniences of life. Not to mention the usc of cattle in many districts of country for the purposes of labor; they supply, during life, those most important of necessarics, milk and creanı; thcy afford the luxuries of cheese and of butter; and at their death they are the sources of supply of the food which has becomc associated with national peculiaritics even, and which is onc of the most nutritious of the neccssaries of life. Nor in death does their utility cease. Their lide provides the protection to our feet and the trappings to our horses-their horns, combs and ornamentstheir hoofs even, and their wastc, supply glue and gelatinc; while their bones afford the handles for our knives and many useful articles in manufactures; and the refuse agaiu, of these, returns to our soils as a most valuable manure.

TIIE DAIRY BRLEDS OF CATTLE.-The great objcct for which cattle are kept by the farmer is either to grow beef for the market, or to produce milk, which shall be converted into butter or clicese, or sold as milk, to smpply the great towns. Hence the former sclcets the fat-producing, and the latter the inilk-producing class of animals. Nature, as a general thing, laas provided that different races of auimals, and different individuals of thesc races, are, more than others, adapted to the secretion of one or the other of these necessary products. The objects of the two secretions are esscutially different, and the tendencies and qualities neccssary for both are never active in the same animal at tho same time. For while the former is a reservoir of the carbonaccous matter of the food, laid by for subsequent use in the respiratory system, the latter is the secretion of a substance necessary to support the young progeny until it is able to sustain itsclf, and to procure from the green pastures the food there provided for it. Hcnce, to prodnce milk is, more or lcss, the natural quality of all kinds and races of cattle; but some will produce large quantities, but thin and poor in quality; some smaller quantities, and rich in oily matter, while others will afford a small quantity, but abundant in solid matter; and the first class would be selected by the milk-man ncar the populons city, the second by the dairy-man whose product was intended to be butter, and the third by the maker of cheesc. 'Thcre are soine tribes of cattle that are both good fatteners and good milkers, bnt never at the same time.

The milk-prodncing breeds are more widely diffused than any other, because they aro capable of being kept to advantage on qualities of 
herbage which are iladcquate profitably to sustain the fat-secreting breeds. Giass-land on the clay soils on the sides of the uplands, and even on the poorer sauds, is quite adcquate to supply the means of making butter or cheesc; but it will very ill repay the person who attempts to feed cattle on herbage so inferior; wlile the rich alluvial feeding pastures which generally skirt the rivers, are fal more profitably employed in raising summer beef than in the production of milk, of cheese, or of butter. Some races of long-horns, of sliort-horns, or of middle horns, or even of polled animals, are to be placed amongst the one elass we have alluded to, and some amongst the other, and we prefer arranging the breeds most celebrated for the quantity or quality of their milk under the first licad, and reserve the second to the races with special aptitude for fattening.

The question arises very naturally how far it is possible, by external conformations of the individual animal, to detect its capabilities for the secretion of milk. There are instanees in every breed where it is evident nature has been more bountiful, or more niggardly, in bestowing the qualities ealculated to produce the secretion for which the race may be cclcbrated; and there are, doubtless, marks, well known to the dairyman, which seldom fail to indieate the power of the animal in the range of qualities peculiar to his race. On the continent of Europe this has been professed to be carried to a very ininute extent. François Guénon, a Frenchman, professed to lave found, by close observation, a mode of deciding authoritatively, not only the quantity and quality of milk which would be given by any particular eow, but also the period for which she would retain her milk after ealving, and this he proposed to do by external appcarances alonc, and these of a somewhat arbitrary

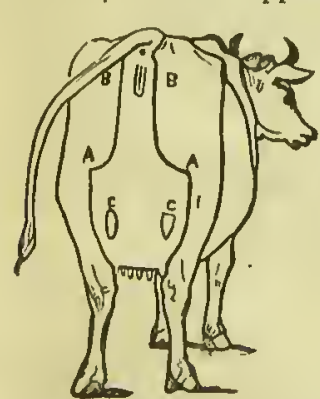
kind.

It is not within the compass of this work to give any thing like a description of the mode he adopted, now inade public,* but the foundation of it is, lis elassification of all kinds of cattle into eight classes, or families; each family is divided into three sections, according to size only, and each section is again subdivided into eight orders.

The distinguishing marks by which he divides these are: 1 . The Gravurc, commencing at the udder, and extending to the bcaring; 2. The Epis, a soft brush of hair upon the the contrary way. The pecnliarities of these marks constitute the distinction between the families and orders. 'Thus, if the gravure be large, the rescrvoir of milk will be large, and the product abundant; if it be formed of fine hair, if the skin be yellowish, and if a kind of bran powder which comes off the skin be of that color, they are all signs of a good

* This work, with the original figures and a full elucidation of the system, can be procured of C. M. Saxton, 25 Park Row, New York. It is an ingenious and plausible system, and well worthy the attention of dairymen.-ED. 
milker. The rationale of this is, that this gravure is but a continuation of, and eorresponds with the laetiferous vessels under the belly of the auinal. These "epis," he states, eorrespond with the reservoir of milk, and are tufts of hair growing the wrong way on the right or left of the bearing. The largest epis indieates the most rapid loss of milk. The eontrepoil, or hair growing the wrong way on the gravure amidst that which grows upward, shows a default in the produetion of milk, even if the gravure be large. We give a fae-simile of his elass 1. Flandrines. So far is a very general deseription of a system which he invests with minutiæe of no ordinary kind, and it is so preeise and prolix that it requires a series of some seore of plates to show the variations of family, elass, and order.

Without definitively pronouneing that there is no merit in his observations, it seems perfeetly elear that many of his indieations are of a eharaeter generally indieative of quality, but are pushed far beyond their legitimate objeets; for while a wide eapacity of upper ndder-a fine hair-a yellow seurf, are somewhat too indefinite to elassify very preeisely, they are just the points which may indieate the fineness of quality, and a large laetiferous eapaeity which may add to the physiologieal signs by which a milking-eow is judged by the practical grazier.

Beauty of form is about the last qualification in a good dairy eow. Sym: metry to a breeder is no eriterion of milking qualities. The parallelogran is the bean ideal of a fattened ox in seetion, and a eylinder is that of lis superfieies-thus exhibiting an essence of loundness, whereas the very eonverse is the perfeetion of a milker, $i_{\text {. }}$. "flatness." The following are the best-settled marks or eharaeteristics of a milking eow. Head small and fine, eye bright and tull, but with a quiet and plaeid expression, neek thin and deep, whieh gives it an appearance of hollowness; sloulder and breast narrow, but projeeting; ribs flat; rumps broad, and tapering down to the knee-joint, owing to the thighs being thin; tail small; udder large and round, with teats well formed, tapering to the end, and at moderate distanee from each other; thin in its skin, and with plenty of skin above; its fore-teats round and full, and with a large subcutaneons or milk vein.

The Ayrshire Cow.-In Ayrshire and the adjaeent portion of the Lowlands there is an adnirable breed of inileh eattle, independently of those that are grazed there for the buteher, which, from whatever souree they originated, owe mueh to the eare and seleetion of judicious breeders. At some period or other there has evidently been a eross of the Durham or Holdemess, and perhaps also of the Alderney. This breed, which beeane established fiom the middle to the elose of the eigliteenth eentury, has found its way not only into England, but also into Ireland and Wales, reeommended by the exeelleney of the eows as milkers, although they are under the middle size. It las been estimated that a good Ayrshire eow will yield, for two or three montlus after ealving, five gallons of milk daily; for the next three months three gallons daily, and a gallon and a half for the following three nontlss. This milk is ealeulated to return about two hundred and fifty pounds of butter annually, or five lundred pounds of eheese. The foregoing estimate is, however, sonewhat exaggerated; and perliaps during the bost of the season four 


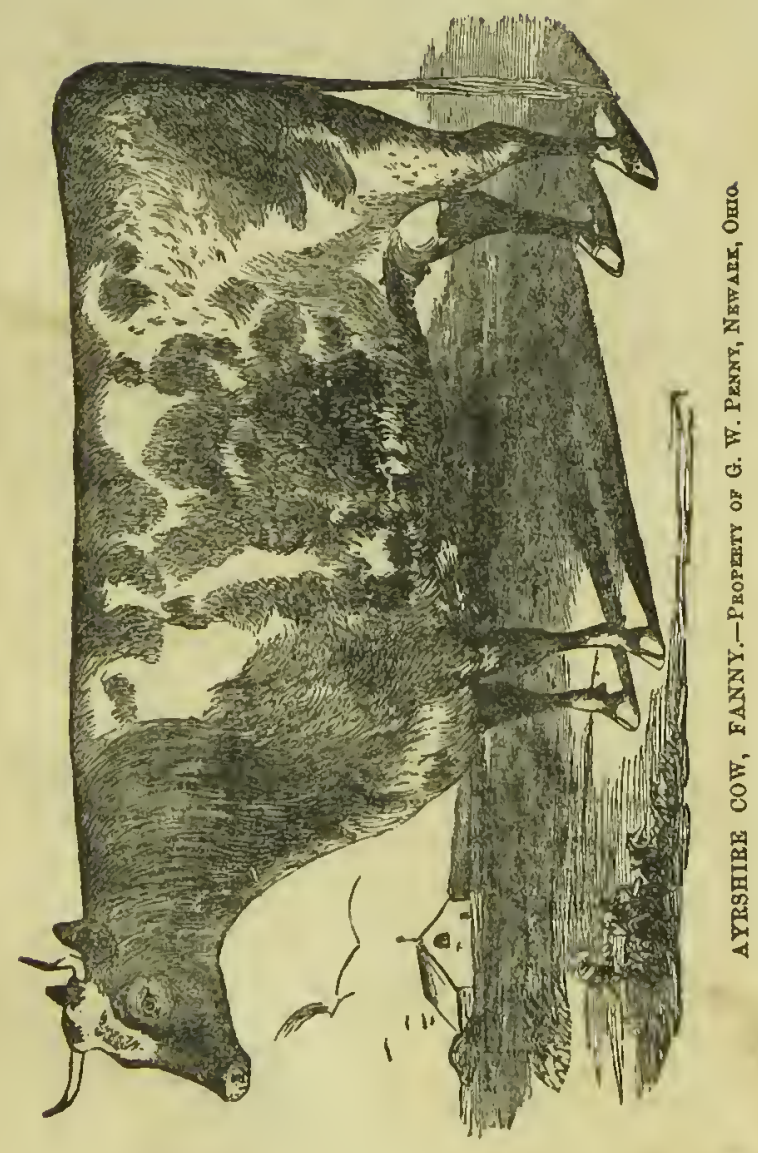


or four and a half gallons of milk is the average produet daily of a good eow, kept in fair eondition. Every thirty-two gallons of unskimmed milk will yield about twenty-four pounds of eheese, and ninety gallons twenty-four pounds of butter. We are supposing a good farm and a first-rate stoek of Ayrshire eows; and eonsidering the size of the eattle, this return from eaeh eow is very eonsiderable. The node in whieh the eows are treated by an enterprising and sueeessful farmer of Kirkum is thus detailed: "He keeps his eows eonstantly in the byre (or slied) till the grass has risen so as to afford them a full bite. Many put them out every good day through the winter and spring, but they poaeh the ground with their feet, and nip up the young grass as it begins to spring, whieh, as they have not a full meal, injures the eattle. Whenever the weather beeomes dry and hot, he feeds his eows on ent grass in the byre, from six o'eloek in the morning to six at night, and turns them out to pasture the other twelve hours. When rain eomes, the house feeding is diseontinued. Whenever the pasture grass begins to fail in harvest, the eows receive a supply of the seeond growth of elover, and afterward of turnips strewed over the pasture-ground. When the weather beeomes stormy, in the months of Oetober and November, the eows are kept in the byre during the night, and in a short time afterward during both night and day; they are then fed on oat-straw and turnips, and eontinue to yield a eonsiderable quantity of milk for some time. Part of the turnip erop is eaten at the end of harvest and beginning of winter, to protraet the milk, and part is stored up for green food during the winter. After this store is exhausted, the Sredish turnip and potatoes are used along with dry fodder, till the grass ean support the eows. Chaff, oats, and potatoes are hoiled for the eows after ealving, and they are generally fed on rye-grass during the latter part of the spring."

The improved Ayrshire eow of the present day lias the liead small, but rather long, and narrow at the muzzle, though the spaee between the roots of the horns is eonsiderable; the horns are small and erooked, the eye is elear and lively, the meek long and slender, and almost destitute of a dewlap; the shoulders are thin, and the fore-quarter's generally light; the baek is straight and broad behind, espeeially aeross the hips, whieh are roomy; the tail is long and thin. The eareass is deep, the udder eapaeious and square, the milk-vein large and prominent; the limbs are sinall and short, but well knit; the thighs are thin; the skin is rather thin, but loose and soft, and eovered with soft hair. The general figure, though sinall, is well proportioned. The eolor is varied with mingled white and sandy red.

Whether the Ayrshires are judged by their aetual produee, or by the external points whieh by experienee and observation are aeknowledged to denote dairy qualities, it must be admitted that they take a ligh rank. From a fair eonsicleration of their merits, it is believed that their adoption for the dairy would secure the following advantages over tho stoek eommonly kept for that purpose in this eountry :

1. $\Lambda$ greater quantity of nilk, butter and eheese for the food eonsuned. 2. Greater uniformity in the general eharaeter of the stoek from its inherent or hereditary qualities. 3. Better symmetry and constitution, and greater tendeney to gain flesh when not giving milk. 


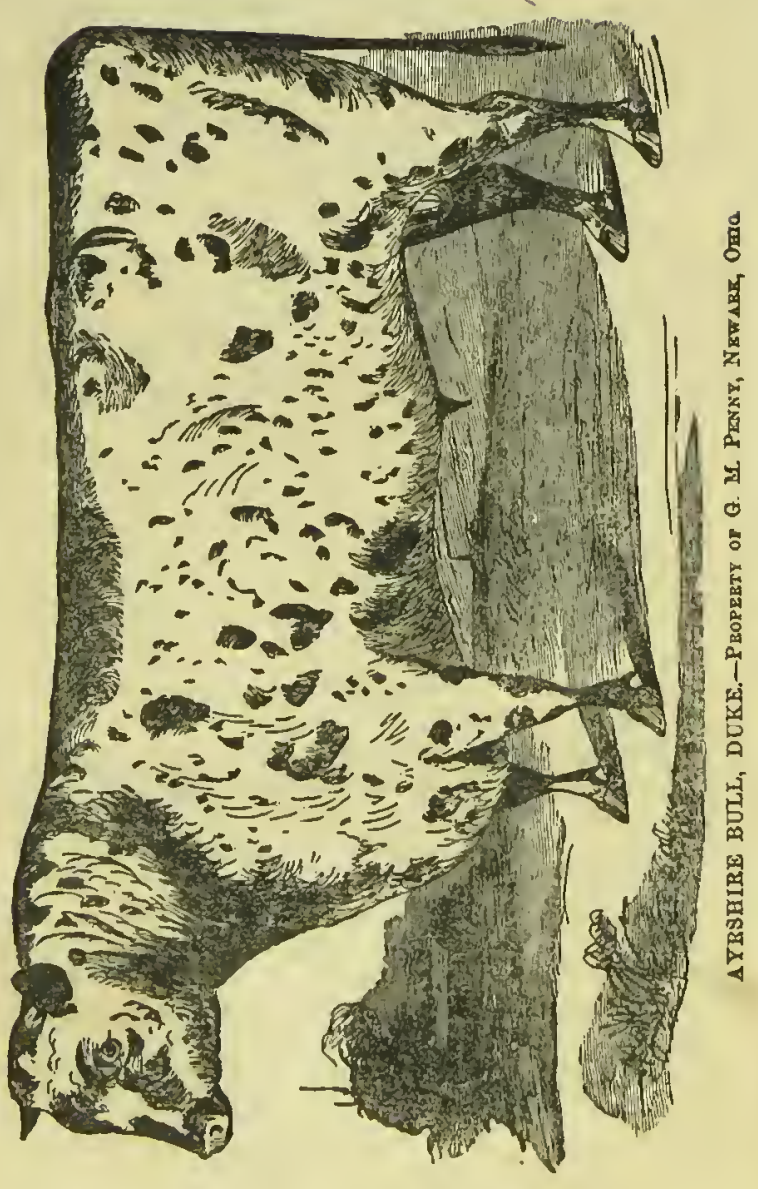


At the present time there are several breeders in the State of New York who are turning their attention to the Ayrshires. The prineipal stoeks known to the writer are those of E. P. Prentice, near Albany; L. G. Morris, Fordham, Westehester eounty ; and J. C. Tiffany, Coxsaekie. Of these Mr. Prentiee's eomprises the largest number, over twenty head. They have been derived from tho imported eow $A y r$, the importations of Mr. Ward, Captain Randall, Mr. Lawson, and Mr. Shurtleff, of Massaeluusetts, and one or two other imported animals.

The Alderneys or Jerseys. - The Jersey eow is a singnlarly doeile and gentle animal; the male, on the eontrary, is apt to beeome fieree after two years of age. In those bred on the heights of St. Ouen, St. Brelade, and St. Mary, there is a hardiness and sound eonstitution that enables them to meet even a Seoteh winter without injury; those bred in the low grounds and rielı pastures are of larger eareass, but are more delieate in eonstitution.

Of the aneient raee it was stated, perlaps with truth, that it had no tendeney to fatten; indeed some eows of the old breed were so ungainly, high-boned, and ragged in form-Meg Merrilies of eows-that no attempt to fatten them might sueeed, the great quantities of milk and eream whieh they produeed probably absorbing all their fattening properties.

Yet eareful attention to erossing has greatly remedied this defeet. By having studied the halits of a good eow with a little more tendeney to fatten than others, and erossing her with a fleshy, well-eonditioned bull, of a race that was also known to produce quality and quantity of butter-the next generation has proved of a rounder form, with a tendeney to make fat, without having lost the butyraceous nature.

Somo of these improved animals have fattened so rapidly while being stall-fed, from the month of Deeember to Mareh, as to suffer in parturition, when both eow and ealf liave been lost; to prevent whieh it is indispensable to lower the eondition of the cow, or bleed, in good time. Such animals will fatten rapidly. Their beef is exeellent; the only defeet being in the eolor of the fat, whieh is sometimes too yellow. It is now a fair question, whether the improved breed may not fatten as rapidly as any breed known.

It was aneiently thought that the eream from the Jersey eow was too rieh for making eheese. Mr. Le Feuvre, of La Houge, who has a fine breed of eows, tried the experimeut two years sinee, and sueeeeded to admiration. It was made from the pure milk, eream and all, as it eomes from the eow. It was found that the quantity of milk that would have produeed a pound of butter, afforded one pound and a half of eheese.

From the quantity of milk which produeed a eleese of twenty pounds' weight, the drainings of the eurds and whey, on being churned, yiekled four ponnds of butter. This butter was of an inferior quality when eaten with bread, but was superior to any other for the making of pastry; it was peeuliarly liard, and of exeellent texture for such use in the hot weather. The writer has tasted eheeses from Mr. Le Feurre's farm quite equal in quality to the riehest double-Glo'ster.

On one or two furms, beside: General Fouzel's, butter is made from 


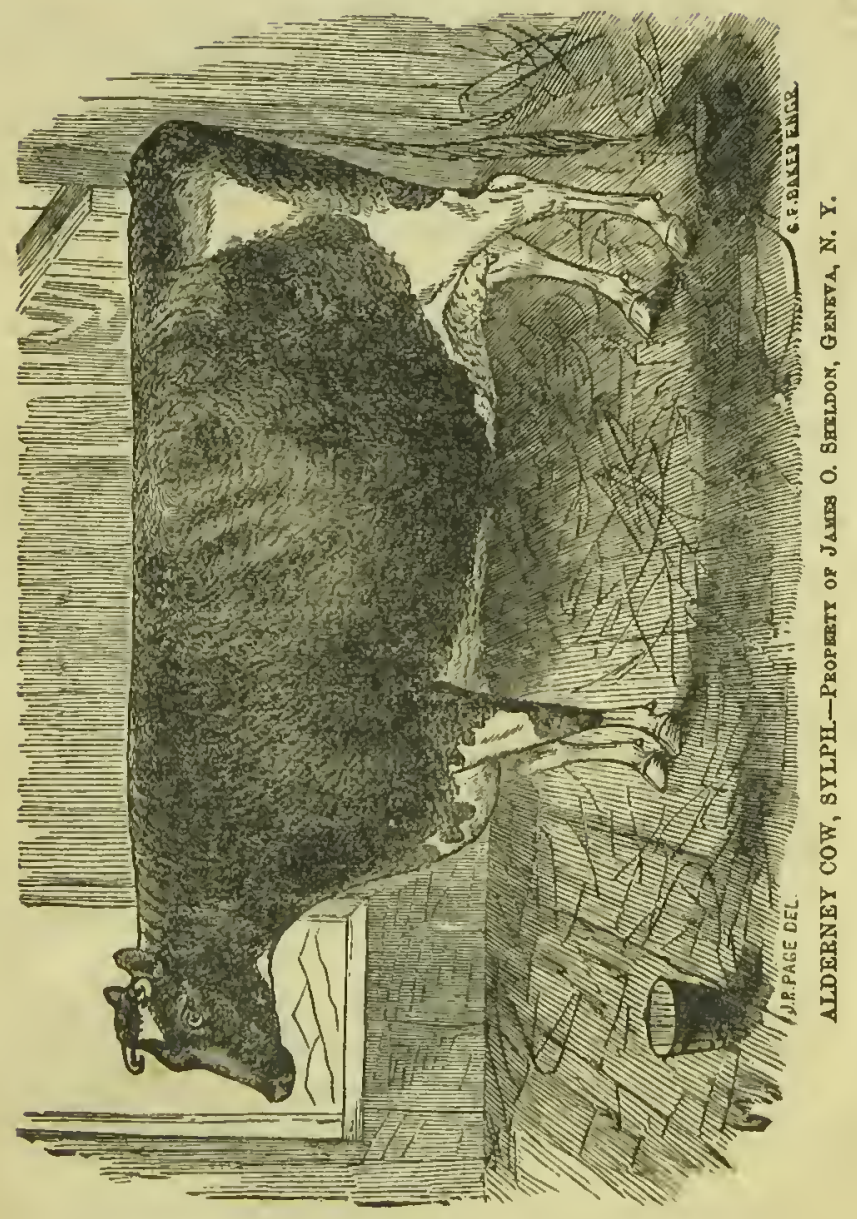


clouted cream in the Deronshire mode; but as this is not peeuliar to Jersey, it is not noticed further than that ten pounds of butter are usually made in five minutes by this proeess. The usual way of procuring the ercam is by plaeing the milk in pans about six inehes deep, the glazed shallow earthen ware having taken the place of the unglazed dcep vessels.

It is admitted that the riehcst milk and eream are produeed by eows whose car's have a yellow or orange eolor withiu. Some of the best cows give twenty-six quarts of milk in twenty-four hours, and fonrtcen pounds of butter from sueh milk in onc week. Such are rare. Good cows afford twenty quarts of milk daily, and ten pounds of butter weekly, in the spring and summer inonths. Butter is made every seeond or third day.

Lactometer's indieate the degrees of riehness of eream whieh the milk of any cow affords, with great niecty. This varics with different food. The modc is to fill the laetometer up to zero with the first milk that is drawn from the eow in the morning; then, when the udder is nearly cmpticd, to fill a seeond lactometer with the residue of the milk, throwing a little ont of the laetometer, to refill it to zero with the very last drops whieh can be drawn from the eow : these will bc ncarly all crcam. The laetometer filled with the first milking may only indieate four degrees of cream, whilc that filled with the last milking may indieate forty degrees of eream. Then, by dividing the sum total, forty-four by two, we have twenty-two degrces of eream, which a very good cow will prodnee; others so littlc as ten or fifteen.

Jerscy butter made when the cows are partially fed on parsnips, or whitc carrots and grass in Scptember and Oetober, when salted and potted will keep till the following spring, prescrving as well as Irish butter, with a mueh less rank flavol.

The foregoing, from Colonel J. Le Couteur, of the Island of Jersey, one of the most intelligent brecerers and judges of this brced of cattle, and the aecompanying illustrations of the improved animals, show that they are not now the angular, ill-shapen animals thcy once were; but that, like the Ayrshircs, they arc worthy the attention of our dairymen.

The Yorkshire Cow,-IIaving given instanecs of milk-produeing eow's from the middlc-horn and erumpled-horn breeds, we plaee ncxt one of tho short-horn class; not, indecd, the high bred Durham short-horn, but a large capacious animal, possessing several of its qualitics, and giving a large quantity of milk, with as mueh aptitude to fatten as is eonsistent with the produetion of milk, and henee is sclected by the dairymen of large towns, and espceially of London, for the supply of nillk for a given period, and then to be fatted on distillers' refusc, and other waste matters whiel a town will afford, and thus give a double pay to the dairyman.

The Yorkshire eow is of mueh larger size than either of those we have bcen eonsidering; and, when fat, will weigh from eight to clcven hundred pounds. Her head is fine, and somewhat small; therc is a serenc placidity of eye, whieh shows a mild and gentlc disposition, tending alike to produce fat and milk. The horns are small and whitc, tho muzzle without black spots; the breast deep and promincnt, but that and the shoulders thin; the neek somewhat narrow, but full bclow the 


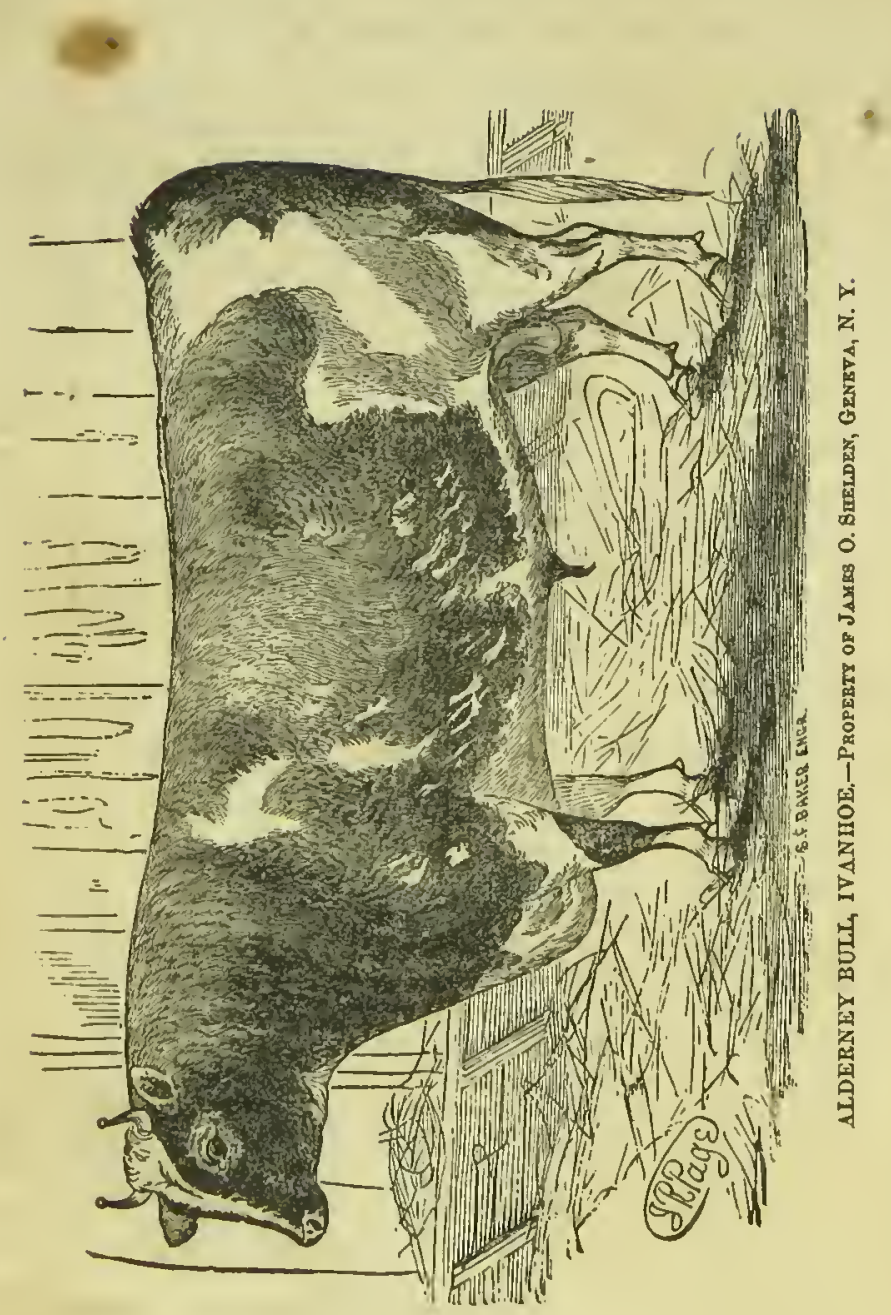


shoulders, and without auy loose skin; the barrel somewhat round; the belly eapaeious; milk-vein large; baek perfectly straight; rump wide, and flat as a table; tail sinall, and set on so that there is almost a straight line from the tail to the head. The prevailing color is roan, or red or white; and sometines white, with the tips of the ears red. The thighs are thin; but the legs are straight and somewhat shot? The udder is very large and muscular, projecting forward, well filled up behind, wand so broad as to give the cow the appearancc of a waddle in her walking. Indeed, her qualities are not inappropriately deseribed in some doggerel lines often quoted; and two of the verses we shall venture to give, as most aptly deseriptive of the Yorkshire cow:

\footnotetext{
"She's broad in her ribs, and long in her rump, $\Lambda$ straight and flat baek without ever a hump;

She's wide in her hips, and calm in her eyes;

She's fine in her shoulders, and thin in her thighs.

"She's light in her neck, and small in her tail,

She's wide in her breast, and good at the pail;

She's fine in lier bone, and silky of skin;

She's a grazier's withour, aud a butcher's within."
}

The quantity of milk given by these cows by far exeecds that of any others, though less perhaps than that of some others in proportion to her size. The writcr lias had instanees where as muel as thirty quarts pcr day, in summer, have beeu given. The distended udder has so swollen before ealving, that she was oblined to be milked several days before she calved; and, after ealving, had to be milked thrce times a day, for fear of the consequences of an over-distended udder. Shc, moreover, gave a large quantity of butter as well as milk, and soon after calving she has given fittecn pounds per week.

All these things bcing considered, and taking into account the earcass value of the eow after she has yielded her milk, it is not too much to say that thicre is no brced of eows so lighly gifted with milk-secreting qualitics who are also otherwise so profitable as the Yorkshire.

The Leicestershire Brect.-The old breed of England has had a more suceessful struggle for existence than the native breed of Gloucestershire. It was here that Bakewell cxcrted his talents to improve the long-horned breed of cattle, and, though he suceeeded in removing the eoarseness fiom these animals, and increased their tendcncy to fatten, it appears he did not attain the object of either establishing or improving their dairying qualities; and hence his brecd is but littlc prized by the Leieestershire dairymen, who prefer the coarser and larger animals, which give large quantities of good milk, to those which have less milkgiving eapabilitics, but are more suitable for the grazier.

The yield of cheese, rather than that of milk, is the objeet of the dairymen of Leicestershirc. A good cow will give some four hundred pounds of cheese, and produco as many gallons of milk in the year, allowing for the scven weeks when she is supposed to be dry. Iu some districts the cows are kept for six, or seven, and even more years, cspeeially when thcy are good cheese producer's; for it is of more consequence to the farmer to have a cow which, for six ycars, gives him an 
annual supply of the stock-in-trade of his farm-his eheese-than to get a few pounds more or less when she is sold. Indeed a smaller difference really takes place than may be at first inagined. The rich Leicestershire grass enables the farmer, on a large scale at least, to sell off his eattle fat, which would have been disposed of for the dairy. Henee as old cows of any kind are not expected to be very valuable grazers, he does not expect her to do wonders; and if he sueeeds in getting her moderately fat, he is satisfied to take a smaller price per stone for her beef than is received for a primer animal.

The Cleshire Breed is, like that of Gloncestershire, or even more so, becoming rapidly extinet. The old breed of the eounty was, like that of most dairy distriets, a long-horned variety; but the vicinity of the large-town dairy system, introdueed into the eountry by the springing up of large towns, has brought here, as elsewhere, the short-horn eow of Yorkshire into competition with the native breed; tle extra quantity of milk they prodnee has been regarded somewhat more than its quality, and, in consequenee, the eharaeter of the Cheshire eheese bas somewhat deteriorated in the markets.

The Dorsetshire Breed.-In this, as in most dairy distriets, the milk is rather an object than either form or fat, and henee a somewhat eoarse, ill-shapen elass of eattle prevails. The eattle are of a long-horn breed, large, and coarse, principally of a red eolor, with flat ehests and buttocks. Attempts have been made to eross this also with the Devon, Hereford, and Ayrshire breeds, but this does not appear to have sueeeeded; and the only advanee the dairymen have been enabled to make in this eounty has been to introduce one Alderney eow to a dairy for every ten or twelve of the native breed; this is found to have a very benefieial tendeney, to inerease the quantity of eream, and to improve much the quality of the butter.

The Kerry Brecl.-Crossing the Irish Channel, there is a hardy smallsized eow eelebrated as a eottier's dairy-eow-the neat pet-like eow of Kerry. Her placid eountenanec, patient, meek deportment, fine head and legs, her small tail, fine shoulders, breast, and quarters, and her skinny udder and large milk-vein, bespeak the eharacteristies of the milker, and well they may, for she is a treasure to the eottage farmer I - so hardy, that she will live where other eattle will starve; she will yield milk at the expense of ber own museles, nay, will yield it abundantly when they seem all but gone; and will give it also of quality so rich, that she is a perfect machine for eonverting the hardest and eoarsest eattle-food into rich and nutritious milk and butter.

FAT-PRODUCING BREEDS OF CATTLE. - Whatever theoretieal objections may be raised against overfed eattle, and great as may be the attempts to disparage the "monntains of fat," as highly-fed eattle are sometimes designated, there is no doubt of the praetieal fact, that the best buteher eannot sell any thing but the best-fatted beef; and of whatever age, size, or shape, a half-fatted ox may be, he is never seleeted by judges as fit for human food. Henee a well-fatted animal always commands a better priec per pound than one imperfectly fed, and the parts seleeted as the primest beef are just the parts where there are the largest deposits of fat. The rump, the erop, and the sirloin, the very favorite 
cuts, which always command from twenty to twenty-five per cent. more than any other part of the ox, are just those parts on which the largest quantities of fat are found; so that instead of the taste and fashion of the age being against the excessive fattening of animals, it is, practically, exactly the reverse. Wherc there is most fat there is the best lean; where there is the greatest amount of muscle withont its share of fat, that part is accounted inferior, and nsed for a different purpose; in fact, so far from fat bcing a disease, it is a condition of muscle, necessary to its utility as food-a source of luxury to the rich, and of comfort to the poor, furnishing a nourishing and healthy diet for their families.

Fattening is a secretive power which grazing animals posscss, enabling them to lay by a store of the superfluons food they take for scasons of cold or scarcity. It collects round the angular bones of the animal, and gives the appearance of rotundity; hence the tendency to deposit fat is jndicated, as we have stated, by a roundness of form, as opposed to the flatness of a milk-secreting animal. But its greatcst use is, that it is a store of heat-producing aliment, laid up for seasons of scarcity and want." The food of animals for the most part may be said to consist of a saccharine, an olcaginous, and an albuminous principle. To the first belong all the starcly, saccharine, and gummy parts of the plants, which undergo changes in the digestive organs similar to fermentation before they can be assimilated in the system; by them also animal heat is sustained. In indolent animals the only parts of plants are deposited and laid up as fat; and, when vigor and strength fail, it is taken up, and also used in breathing to supply the place of the consumed saccharine matter. The albuminous, or gelatinous principle of plants, is mainly useful in forming muscle, while the ashes of plants, the unconsumable parts, are for the supply, mainly, of bone, hair, and horn, but also of muscle and of blood, and to supply the waste, which continually goes on. Now, there are sevcral qualitics which are essentially characteristic of a disposition to fatten. There have not, as yet, been any book-rules laid down, as in the case of Mr. Guénon's indications of milking cows; but there are marks so definite and well understood, that they are comprehended and acted upon by every grazier, although they are by no means casy to describe. It is by skillful acumen that the grazier acquires his knowledge, and not by theoretical rulcs; observation, judgment, and experience, powerful perceptive faculties and a keen and ininute discrimination and comparison, are essential to his success.

The first indication he relies on is the touch. It is the absolute critcrion of quality, which is supposed to be the kcystone of perfection in all animals, whether for the pail or the butcher. The skin is so intimately connected with the internal organs, in all animals, that it is questionable whether even the schools of medicine might not make more usc of it, in a diagnosis of discase. Of physiologieal tendencies in cattle, lowever, it is of the last and most vital importance. It must neither be thick, nor hard, nor alhere firmly to the muscles. If it is so, the animal is a hard grazer: a difficult and obstinate fecder-no skillful man will purchase her-she must go to a novice, and even to him at a 
priee so low as to tempt him to be a purchaser. On the other hand, the skin must not be thin, like paper, nor flaceid, nor loose in the hand, nor flabby. This is the opposite extreme, and is indicative of delieateness, bad, flabby flesh, and possibly of inaptitude to retain the fat. It mist be elastic and velvety, soft and pliable, presenting to the touch a gentle resistance, but so delieate as to give pleasure to the sensitive hand-a skin, in short, which seems at first to give an indentation from the pressire of the fingers, but which again rises to its plaee by a gentle elasticity. The hair is of nearly as much importance as the shin. A hard skin will have straight and stiff hair; it will not lave a curl, but be thinly and lankly distributed equally over the surface. A proper grazing animal will have a mossy eoat, not absolutely curled, but having a disposition to a graceful eurl, a semifold, whieh presents a waving inequality, but as different from a elose and straightly-laid coat, as it is from one standing off the animal at right angles, a strong symptom of disease. It will also, in a thriving animal, be licked here and there with its tongue, a proof that the skin is duly performing its functions. There must be also the full and goggle eye, bright and pressed outward by the fatty bed below, because, as this is a part where nature always provides fat, an animal capable of developing it to any considerable extent will have its indieations here, at least when it exists in exeess.

So mueh for feeding qualities in the animal, and their conformations indieative of this kindly disposition. Next come such formations of the animal itself as are favorable to the growth of fat, other things being equal. There must be size where large weights are expeeted. Christmas-beef, for instance, is expeeted to be large as well as fat. The symbol of festivity slonld be eapaeious as well as prime in quality. But it is so mueh a matter of choiee and eirenmstance with the grazier that profit alone will be his guide. 'The axiom will be, however, as a general rule, that the better the grazing soil the larger the animal may be; the poorer the soil the smaller the animal. Small animals are unquestionably mueh more easily fed, and they are well known by experienced men to be those best adapted to seeond-rate feeding pastures. Bnt beyond this there must be breadth of earcass. This is indieative of fattcuing perhaps beyond all other qualifieations. If rumps are favorite joints, and produee the best priee, it is best to have the animal whieh will grow the longest, the broadest, and the best rump; the same of crop, and the same of sirloin; and not only so, but breadth is essential to the eonsumption of that quantity of food which is necessary to the development of a large amount of fat in the animal. Thus a leep wide ehest, favorable for the respiratory and eireulating funetions, enables it to consume a large amount of food, to burn up the sngary matter, and to deposit tho fatty matter-as then useless for respiration, but hereafter to be prized. A full level erop will be of the same physiologieal utility, while a broad and open framework at the hips will afford seope for the aetion of the liver and kidneys.

'There are other points also of much importanee; the head must be small and fine; its special use is indieative of the quiek fattening of the animal so eonstrueted, and also it is indicative of the bones being small 
and the legs short. For constitutional powers, the beast should have his ribs extended well toward the thigh-bones or hips, so as to leave as little unprotected space as possible. There must be no angular or abrupt points; all inust be round, and broad, and parallel. Any depression in the lcan animal, will give a deficient deposit of flesh and fat at that point, when sold to the butcher, and thus deteriorate its valuc; and henec the animal must be round and full. But either fancy, or accident, or skill-we will not pretend to say which-lias associated symmetry with quality and conformation, as a point of great importance in animals calculated for fattening; and there is no doubt that, to a certain extent, this is so. The beast must be a system of mathematieal lines. To thc advocate of symmetry the setting on of a tail will be a condemning fault; indeed, the ridge of the back, like a straight line, with the outline of the belly exactly parallel, vicwed from the side, and a depth and squareness when viewcd from bchind, whieh remind us of a gcometrical cube rather than a vital economy, may be said to be the indications of excellence in a fat ox. These qualities are inherent in some brecds; there may bc eases and instances in all the superior breeds, and in most there may be failures.

By far the first in the list for feeding excellencc are-

The Short-IIorn or Durham Breed,-The origin of the breed is involved in grcat obscurity. They are supposed by some to be traced into Holderness; and to have been imported from Holstein, aceording to others; froun continental Europe they certainly seem to have come; and, being successively inproved by a variety of breeders, they have ended in that distinct race of animals, extraordinary beyond all others for thcir astonishing propensities to feel. Others, again, refer their origin to a native race of cattle called the Teeswater, because they have from time immemorial inhabited the valley which the Tees has formed by its washings down of the mountain limestone rocks, in which it has its origin; these, it is said, being crossed by the Holderness importations, gradually became a new race.

The latc Mr. Bates traces back the short-horns to a breed in the possession of the Aslabics of Studley, and the Rev. H. Berry to an improvement in the East Riding of Yorkshire, by the importation of a breed from Holland by Sir W. St. Quintin of Seampston. Of these early ages of the short-horns, lowever, it is hardly nceessary to say more than this-that a breed from tiunc immemorial inhabited the valley of the Tecs, and, trained and bred to feed, for a vast succession of generations, on its fertile deposits, acquired the habits of specdy fat-forming; for in these vallcys, wherc hay alone will feed the largest ox, the production of fat would be so far an object that breeders would always selcet the best and easicst feeding amimals; and thus the character of the district, through a number of centuries, might casily lay the groundwork of that improvement which the Milbanks, the Greys, the Booths, the Coatcs, and, above all, the Collings, have cffected.

We will give the latest description of the qualities of the modern short-horn from the most rccent authority, $\mathrm{M}_{\mathrm{r}}$. Diekson. After referring to the general symmetry of the frame and its delicate color, either deepred ercam-eolored, white, or delicate roan-the latter the most fashion- 


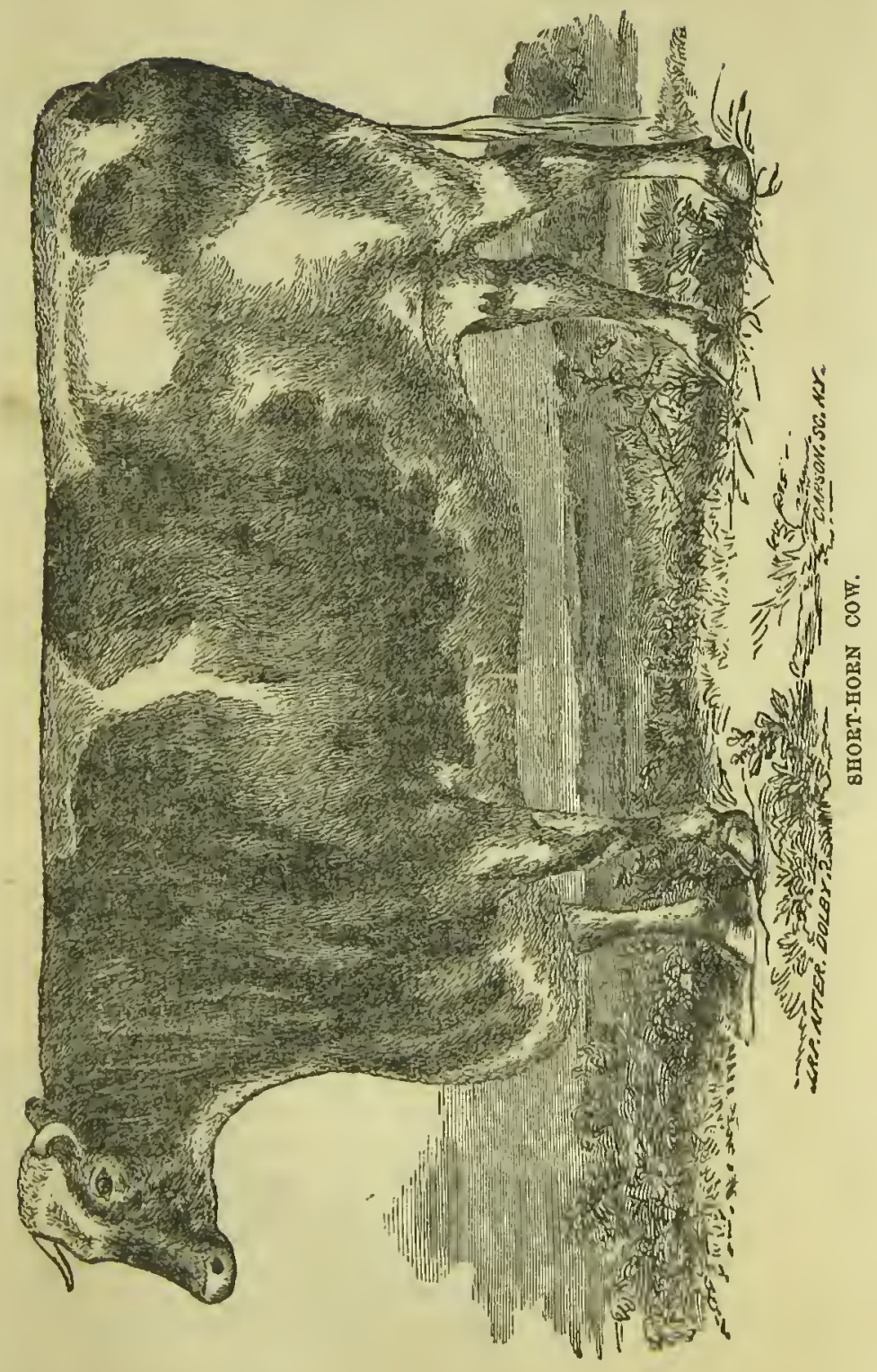


able and indeed prcvailing color-he speaks of it as possessing "the mellowest touch, supported on small clean limbs, showing, like those of the greyhound and the race-horse, the union of strength with fineness, and ornamented with a small, lcngthy, tapering head, ncatly set on a broad, firm, deep neck; furnished with a snall muzzle, wide nostrils, prominent mildly-bcaming eyes; thin, large, vciny ears, set near the erown of the head, and protected in fiont witl semicircularly-bent white or waxy-colored short, smooth, pointed horns; all these several parts combine to form a symmetrical harmony which has never been surpassed in beauty and sweetness by any other species of the domesticated ox."

Keeping in mind what was said to be the perfection of a fat animal, the same authority, speaking of the short-horn, says: "We have a straight level back from behind the horns to the top of the tail, full buttocks, and a projecting brisket; we have, in short, the rectangular form; we have also the level linc across the hook-bones (bip), and the level top of the shoulder across the ox, and perpendicular lines down the hind and fore legs on both sides; thesc constituting the square form when the ox is viewed before and behind; and we have straight parallel lines from the sides of the shoulders along the utmost parts of the ribs and the sides of the hind quarters; and wo have these lines connected at their ends by others of shorter and equal length across the end of the rump and the top of the shonlder; thus constituting the rectangular form of the ox when viewed from above down the back."

It will be very wide from our purpose to show either the immense amount of fat which has at one time or another accumulated on the backs of these wondcrful animals, or the spced with which this has been done. Ncither would it tend much to elucidate the principles of brceding or grazing to detail at any length the prices which short-horns have coinmanded and do command.

Nor is it in their rapid fattening alone that this race of cattle excels. They are, beyond all question, the most remarkable for early maturity. Fat deposits are gencrally the result of a mature state of the animal. There are few animals who will lay it on, to any degree, at lcast, until they arc fully formed. The short-horn is an exception. They commence the fat-forming process as calves. This seems to increase with their growth, and at a year old they have all the semblance of cows.

The fecders of short-horns, instcad of keeping them to three, four, or five years of age, fatten them and sell them off at from two to two and a half year's; they can thus turn off one-half more at least, if not a greater proportiou, of becf, from their farms or thcir stalls, than could possibly be done with any other breed. Ience they have quick rcturns and large amounts of becf for the food-consumer. We will not deny that the short-horn requires good keep, and shelter, and care. She nceds nourisling diet; but she pays for all, for she is a cow when another is a calf-the ox is fat when the other is growing. Hence the shorthorn stands the very first on the list of the fat-producing brecds of
cattle.

The Hereford Breed.--This is a middle-horn breed of cattle, upon which a good deal of pains has lately been taken. The success of short- 
horn breeders, - of the Booths, the Bates, the Wileys, the Hoppers, and a score more of short-horn patrons, have caused a healthy einulation, and the difference between the Hereford eattle now exhibited, and those shown some ten or twelve years ago, shows not only that these breeders have judginent and skill, but it must also be confessed, that the breed have fattening capabilitics. The old Hereford was a decp-brown animal, sometinies with an ochery cast, free from white, like the Devons; but an improved breed now possess the county, in which the invariable fashion is a dark red, with a white face, white belly, and not unfrequently a white back. The skin is thicker and less mellow than that of the short-horn, nor has the hair the mossy softness or graceful curl of the latter. The eye is full and lively, the chest decp and broad, the loin also broad, and the hips well-expanded; a level broad rump, a round barrel, and full crop, full, decp flank, well-ribbed home; small bones, clean and perpendicular thighs, belly almost parallel with back, head small. Indeed, color and symmetry are perhaps the predominant qualifications which secure the high faror of the breeder.

From the above description it will be seen that the Hereford, possessing inany essentials in form, is destitute of the quality producing early maturity and specdy disposition to fatten. Me lays on his flesh, soft and mottled, on the best parts; he has full sirloins, rumps, and crop, but he shows his beef on the outside; and he requires much more time to develop his qualities than the short-horn. In milking qualities the cow is even behind the ox in feeding, and it must in general be three and a half to four years old before it can be fatted with any very marked sucecss. They require a rich pasture, though a hardy animal, and the average weight when fat does not execed eight to ten hundred ponnds. Herefordslire being inore a brecding than a feeding county, the cattle are reared there, and sold off at threc years old to graze in the connties of Lcicester, Northampton, and the rich grass districts; but, with all its good qualities, it must be admitterl that it requires from ten to twelve months more to feed than its more favored compeer, the short-horn. We give a sketch of first-rate specimens. Much controversy has gone on litcly as to the merits of the two breeds-the sluort-horn and the Hereford; but it must be conceded, that while the short-horn is penetrating into the heart of Scotland, into the sonth of England, and into the county of Gloucester, on the one hand, and into Norfolk on the other, the IIcreford is bardly liceping his ground, lie is making no inroads into any one important new grazing distriet; and unless the gigantic efforts now made to amend the characteristies of the breed effect something more, they will dwindle still further away.

The West Ilighland Scot.-Next to the Ilereford in the ranks of fattenjng animals, we place this breed of eattle; and they well deserve it,for they will fatten in places and on food on which both the short-horn and the Hereford, too, would perish. This West Highland breed is somewhat wild in its nature, and will not bear the least confinement, tying, or control. It is eminently gregarious, and if kept alone will generally fret and pine. The peculiarity of the breed is, that it is a small auinal, generally deep jet-black, pale red, or dun, seldom any white spots on any part of the body; its horns are long, and turned 


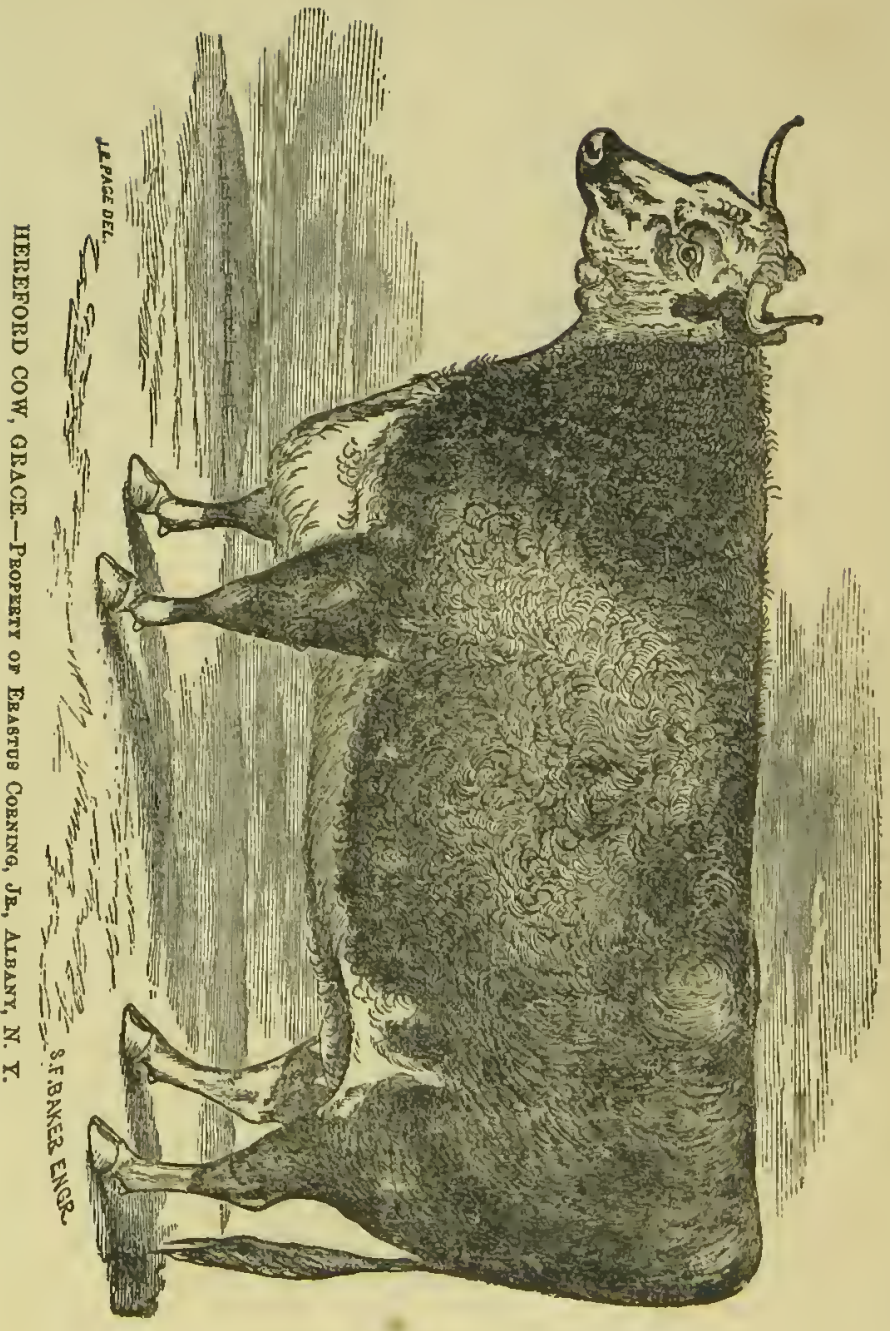


upward and outward. The coat is peeuliar, soft, long, and absolutely curled, so as to form a sort of flece. Another peculiarity is, that they form their beef almost entirely on the back, whieh is therefore straight; the body is round; and they lay on fat rapidly under cireumstances in which another animal would literally starve.

He can assimilate, from a soil so barren as to be sterile for others, as much food as will enable him to fecd-for to grow is out of the question, that process is performed on his native hills; if indulged, however, he will pay for it in the rapidity of his fattening, and the excellenee of his beef. They will weigh, with amazingly little eare, from seven hundred to one thousand pounds. The exceptions to this rule, however, are very important in special cases. The Duke of Northumberland having a very promising Argylshire "stot"-bullocks, as they are called more generally in England-kept him as long as he saw him improve, to see what he wonld weigh. He was five and a half years old, and weighed exelusive of offal, one thousand four hundred anil four pounds. Though, perlaps, one of the heaviest of the breed ever slaughtered, he was neither thic fattest nor the most inaetive, but seemed in that state to posscss all the activity which he had on his native hills. To give an idea of his keeping, and of the hardihood of his race, it is only neecssary to give an aecount of his food. In the first winter he was turned out to a poor pasture, with a little bad hay; in the summer he had again a poor land pasture; in the next winter he had again a poor pasture, but a few turnips; in the following summer he had a fair pasture, and the same pasture in wintcr, with a more liberal allowanec of turnips; in the third summer he was tolerably well grazed; in the fourth winter, he had as many turnips as he could eat in the sleltered straw fold, and in the summer in which he was fatted, he had all the indulgence of a feeding animal, viz., eut elover, hay, mangel-wurzel, turnips, bean-meal, and a little oil-cake; the latter of which he always disliked. Mr. Quarl says his "fat was distributcd in an uneommonly equable manner, of a color resembling the finest grass butter, and as firm as wax; the muscle was in ample proportion, bright in color, of fine texture, and beautifully marbled by admixture of his excellent fat."

The Devon Breed.-If this liad been a treatise on drawing eattle, we should have placed this middle-horned deseription of animals first in our list, instead of alınost last. They are physiologically well formed animals; they are a very old and crirefully-kept distinet breed of animals. They are docile and tractable, patient and gentle; hardy, notwitlıstanding their warm and humid elimate; but they are not first-rate milkers, although very good feeders. They will grow to a considerable size; and they produee a elass of beef at all periods of their growth of capital quality. The red color-all red, and nothing but red-is a sine qua non in a Devonshire ox; he has a moderately straight top, a fine serene countenance, and small head; a somewhat thin skin, covered with eurly hair. The rump is narrower than in the short-horns and the cline lighter and flatter; but the brisket is large ${ }^{\circ}$ and full, the legs fine, the shoulder slanting, the neck long and thin. He is a beast of draught, and for this he is unequaled. 


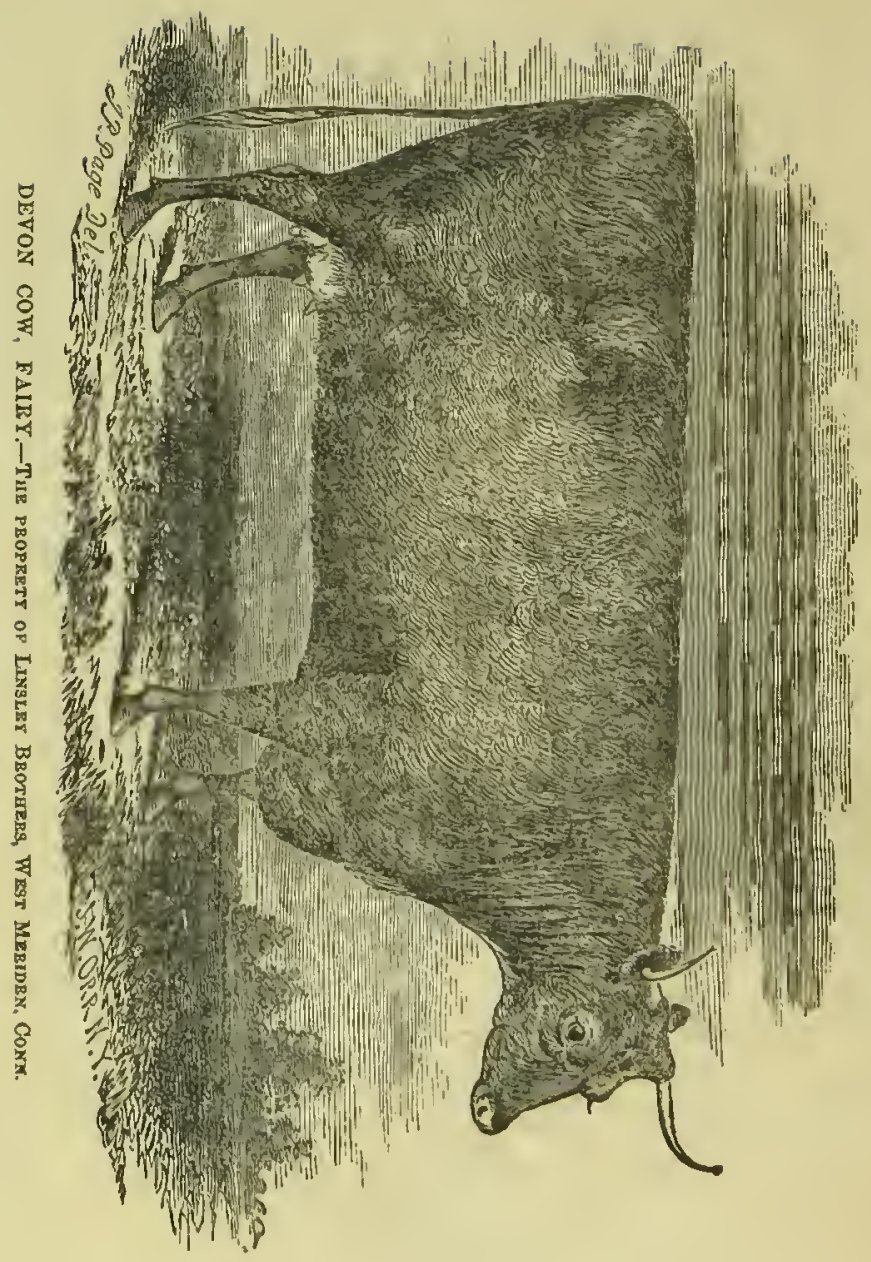


Mr. Parkinson, in his invaluable Treatise on Live Stock, gives the weight of some specimens of six years' old cattle, which weighed some eight hundred pounds, but the cows much less. He says of them: "On the whole, they must be allowed to be good cattle for their soils, and particularly where oxen are worked at the plow. When slaughtered, they are a sort of beef that suits the consumption of many customers."

Among the most successful brecders of Devonshire cattle may bc mentioned Mr. Turner, of Barton, near Exeter, Mr. Quartly of Motland, (who is the most distinguished winncr, Mr. Merson of Brinsworthy, and Mr. Davy of Moulton.

Galloway Breed. - The Galloways are prominent fat-producing animals of Scotland, and are bred in great numbers in Galloway and Dumfricsshire. They are hornless, mostly black, arc small in size, compact, short-legged, hardy, havc thick mossy coats, and are good fcedcrs. As milkers they are very indifferent, although, like all small milkers, the quality is rich. They are mostly driven south and fed off on the good pastures in England, and like the Highlanders, bring the highest price in the London markets. The joints are of a good size for family roasts, and the meat is of the best description; thus making it the most desirablc.

The Angus Brecd,-We shall close our remarks on the fit-producing class of oxen by shortly describing a hornless or polled race of animalsthe Angus "Doddies," as they are called. Being bad milkers, they are generally used for grazing, and very-much fatted in their native country; they are also preferred for fceding by the graziers of Leicestershire and Norfolk. Their color is generally black, but occasionally red; the head fine; the breast deep; the back not quite straight, being a littlc depressed at the loin and somewhat narrow; the eye full and clear; the touch generally good, and the hair thick and curly. The tendency of the flesh, as in all the lardy Scottish cattle, is to form on the back; but they will weigh from a thousand to fourteen hundred pounds.

Qualities are so co-existent with conformation that, as a general rule, it may be received as an axioru. And as dairy and butcher qualities are gencrally combined only to a very limited extent, and as both qualities are rarcly ligh in the same brecd, it becomes the agriculturist to makc his selection according to the object he has in view.

TIE PRINCIPLES OP CATTLE-BREEDING.-We may offer a few remarks on the principles by which the brceder ought to be guided in the successful management or improvement of his stock, in whaterer points he wishes it to exccl, whether in those required by the grazier or the dairy-farmer. Every man, whether grazicr or dairy-farmer, is desirous of turning his cattle to the most advantage; nor can this be done, unless the size of the farin, soil, climate, thic produec, and thic nature and extent of the pasturagc, be well considered; for the cattle that the farm is best adapted for maintaining will be the most profitable. It is, however, essential, whatever the cattle be, whether for the purpose of the dairy, or for the immediate supply of the markets with their flcsh, 


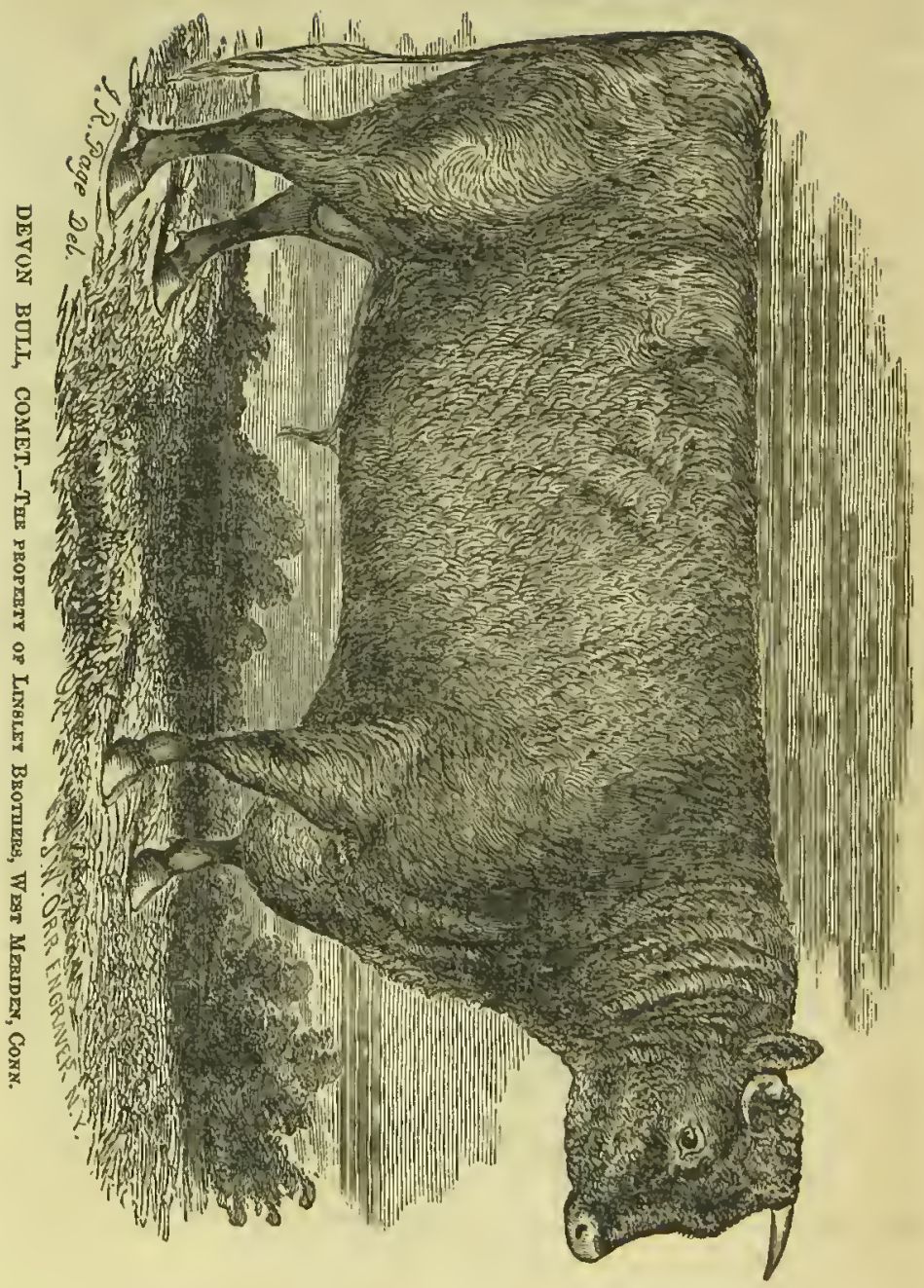


that they be well bred, and execllent of their kind. To the dairy farmer, the most important points are, the quantity of milk yielded, its quality, its value for the produetion of butter, or of eheese, a freedom in the cows from vieious habits and ill temper, their eharaeter as good and healtlyy breeders, the ease with whieh, when uscless as milkers, they become fattened for the market, and the nature and quantity of food requisite for this purpose. To the grazier, the quiekness of beeoming fat, and at as little expense as possible, the fineness of the grain of the meat, or of the museular fibers, the mode of laying on the fat, the smallness of bone, soundness of constitution, and eongeniality with the soil and the elimate, are the ehief points whieh he takes into eonsideration. If he is wise, he will never stint keep, nor transfer his stoek from a good to an indifferent soil; and this is true also with respeet to the dairy-farmer.

Contour, or beauty of form, is desirable; indeed, it is nore or less conneeted with what may be termed utility of form, that is, a preponderanee of those parts in the beast whieh are most delieate for the table, and bear the highest priee, over the parts of inferior quality, or offal. This is eonneeted with smallness of bone, but not a preternatural smallness, and witl a tendeney to depositions of fat, which, however, should not be earried to an extreme, otherwise the quantity of flesh is disproportionate, and its fiber is dry and insipid; nor is the weight of the beast proportionate to its admeasurement. Previously to the tine of Mr. Bakewell,* the eattle in general were large, long-bodied, big-boned, flat-sided, slow to fatten, great eonsmmers of food, and often black, or foul-fleshed, or, as it is ealled in Yorkshire, "lyery." This truly patriotie breeder, aeting upon true prineiples, energetieally set to work upon the improvement of eattle, and in defianee of opposition and a thonsand diffieulties, lived to see the suceess of his long-eontinued efforts. Experienee and a elose and aeute observation had tanght him that "like produees like;" in other words, that the qualities of the parents, sueh as beauty, or utility of form, clisposition to fatness, goodness of flesh, abundanee of milk, and even temper, were inherited by their offspring; and that by eareful seleetions on the side both of the sire and dam, a breed miglit be nltimately established to whieh the title blood eould be distinetly applied. Tlis, of eourse supposes a primary seleetion, then a seleetion of such of the offspring as exlyibited the properties which eonstituted their perfeetion, in the highest degree; and again of the offspring of

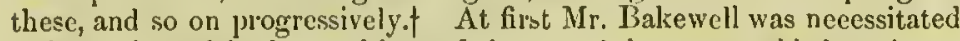
to breed in and in, but as his stoek increased, he was enabled to interpose more or less remote removes betwcen the meinbers of the saine family; and ultimately he established the Dishley, or New Leieester long-horns, a breed remarkable for smallness of bone, roundness of form, aptitude to fatten upon a moderate allowanee, and fineness of flesh.

\footnotetext{
* Born at Dishley, in Leicestershire, 1725. His father and grandfather resided on i. - estate before him.

t to- Bates' rulo was, "Breed in and in froma vau stocr, and you commit ruin and devastative. but if a good slock be selected, you may breed in and in as much as you please;" and $11 \cdot$ followed this practice for fifty years, and yet bad ove of the finest berds ever known.
} 
But while he aceomplished this, rendering the aninals admirably suited for the grazier, it was found that their qualities as milkers were much deteriorated; the dairy-farmers conscquently retained their old breed, noted for the richness, thougb perhaps not the great abundance of the milk. We are not here speaking about the differences or the distinguished excellences of the various breeds of cattle, but of the principles upon which excellences, it matters not of what sort, may be obtained. "Like produces like," and both parents inust present the same excellencies, the sane characteristics. It was by following out these rules that Mr. Bakewell arrived at perfection in his breed; indeed by some he is thought to have pushed his principles too far, and the following remarks have perliaps some justice in them:- "It was his grand maxim, that the bones of an animal intended for food could not be too snall; and that the fat, being the most valuable part of the carcass, could not, consequently be too abundant. In pursuance of this leading theory, by inducing a preternatural smallness of bone and rotundity of carcass, he sought to eover tbe bones of all his animals externally witb masses of fat. Thus the cntirely new Leicester breed, from their excessive tendeney to fatten, produce too small a quantity of eatable meat, and that, too, necessarily of inferior flavor and quality. They arc, in gencral, found defective in weight, proportionally to their bulk; and if not thoroughly fattened, their flesh is crude and without flavor ; while, if they be so, their carcasses produee little else but fat, a very considerable part of which must be sold at an inferior pricc, to make candles instead of food; not to forget the very great waste that must ever attend the consumption of over-fattencel ineat.

"This great and sagacious improver (Mr. Bakewell), very justly disgusted at the sight of those huge, gaunt, leggy, and nisshapen animals with which his vicinity abounded, and which scarcely any length of time, or quantity of fool, would thoroughly fatten, patriotieal!y determined upon raising a more sightly and profitable breed; yet, rather unfortunately, his zeal impelled him to the opposite extreme. Having painfully, and at much cost, raised a variety of cattle, the ehicf merit of which is to make fat, he has apparently laid his dicciples and successors under the necessity of substitnting another that will make lcan." Illustrations of Natural History, p. 5.

Granting the truth of these strictures, which we scarcely can to the full extent, what is the inference as it respects the system of breeding? Namcly, this : that by pursuing the proper mode, by proper selections, and by joining like excellencies and properties in the sire and dam, and not by rashly crossing distinct breeds, but by making one breed tho great foundation, and working upon it, remcinbering that "like produces like," not only will the point aimed at be attained, but it may even be overshot, thus demonstrating the power which the judicious breeder possesses.

Sinee Mr. Bakewell's time the New Leicester breed has becone degenerated; by some the stock has been bred in and in too closely, and by others very injudiciously crosscd. In tbe mean tine the slort-horned breeds of cattle bave been gaining an ascendancy, so that few really excellent long-borns are now to be soen. This, bowever, bas notling 
to do with the great principles we have endeavored to illustrate; they apply alike to all breeds of eattle. Every breeder, then, shonld well consider the properties of the stock from which he breeds, investigate their good qualities and their bad qualities, and while he endeavors to keep up or inprove the former, he should study to remove the latter. His selection must be strict; the heifer or cow shonld have as few of the bad points as possible, every excellenee in perfection, and be in good health ; the bull shonld be of the same kind, and if related, only in a remote degree; nor slionld he have been brought up onl a pasturage differing from that of the cow, or under the influences of a different local elimate; he should not only possess the good points desired, in all their perfection, but lie should also lave the points which the farmer considers to be the exeellenees of his own stoek, as admirably developed. Thus acting with judgment he may expect improvement; and if he fail, there is some coneealed fault which has been overlooked, either on the one side or the other, or some defect in their parents, and whieh (in accordance with the tendency there is in families to exhibit, from time to time, certain peeuliarities, latent perhaps for a generation) has again made itself manifest; consequently, on both sides there ought to be what is termed "good blood." But this is to suppose a stock already improved to a great extent; and here we may repeat the injunctions lard down by the Rev. II. Berry, which more partieularly apply to the farmer commencing de novo: "A person selecting a stock from which to breed, notwithstanding he las set up for liimself a standard of perfection, will obtain them with qualifications of different descriptions, and in different degrees. In breeding from such he will exereise lis judgment, and decide what are indispensable or desirable qualities, and will cross with aninals with a view to establish them. IHis proeceding will be of the 'give and take kind.' He will submit to the introduction of a trifling defeet, in order that he may profit by a great excellence; and between exeellences perhaps somewhat incompatible, lie will decide on which is the greatest, and give it the preference.*

"To a person commeneing improvement, the best advice is to get as good a bull as lie ean, and if he be a good one of his kind, to use bim indiscriminately with all his cows; and when by this proeceding, which ought to be persisted in, his stock has, with an oceasional change of bull, become sufficiently stamped with desirable excellenees, his selection of males should then be made to eradicate defeets which he thinks desirable to be got rid of.

"He will not fail to keep in view the necessity of good blood in the bulls resorted to, for that will give the only assurance that they will

* "A person would often be puzzled; he would find diflorent individuals possessing difforent perfections in different degrees:-ono, good flesh and a tendoncy to fattell, with a bad form: anothor; with fine form, but bad flesh, and little disposition to acquire fat. Wlat rule should he lay down, by tho obsorvance of which good might be grenerally producod, and as littlo evil as possible effeeted? UTuLTY. Tho truly good form is that whicl secures constitution, health, and vigor: a disposition to lay on thesh with tho greatest possible reduction of offal. Having obtained this, other things are of minor, though perhaps sometimes of considerable importance." -Prize Essay, hy the Rev. H. Borry. 
transunit their own valuable properties to their offspring; but he mnst not trust to this alone, or be will soon run the risk of degeneraey. In animals evineing an extraordinary degree of perfeetion, where the constitution is decidedly good, and there is no prominent defeet, a little elose breeding may be allowed; but this must not be injndiciously adopted, or earried too far; for, altlrongh it may inerease and confirm valuable properties, it will also inerease and confirm deferts; and no breeder need be long in discovering that, in an improved state, animals have a greater tendeney to defeet than to perfeetion. Close brceding from affinities impairs the eonstitution and affeets the procreative powers, and therefore a strong cross is oecasionally neecssary."

The dairy-farmer, lowever, is less eoneerned in this high breeding than the grazier; yet he is not by any means indifferent in the matter ; for his aim ought to be, to obtain a breed no less valuable as milkers than for their disposition to fatten when the milk is dried. These two qualifieations are not to be attained very easily; yet they may be, and, indeed, have been attained, and especially anong the improved shorthorn breeds, as those of Durham and Yorkshire, or the cross-breeds between the old Shropshire, and the Holderness. The breeds most valued in the great dairies around the metropolis are mixed between the Yorkshire, Holderness, and Durham. For quality and quantity of milk they are cminent; they yield, on the average, each eow, two gallons of milk at a tine, and often nine guarts; and when dry, they are in general readily fattened for the buteher.

With respeet to the points of symmetry in eattle, of whieh the various breeds exhibit several degrees of modifieation, there are ecrtain rules which are generally aeknowledged as applieable to good eattle of all kinds.

The Bull.-The forehead of the bull shonkl be broad and short, the lower part, that is, the nasal part and jaws, tapering; and the muzzle fine; the eals moderate; the neek gently arehed from the head to the shoulders, small and fine where it joins the head, but boldly thiekening as it sweeps down to the ehest, which should be deep, almost to a level with the knees, wrth the briskets well developect. The shonlders should be well set, the shoulder-blates oblique, with the humeral joint advaneing forward to the neek. 'The barrel of the ehest should be round, without hollowness between it and the shoulders. The sides should be ribbed home, with little spaee between then and the hips; the whole buly being barrel-shaped, and not that-sided. The belly shonld not hang down, being well supported by the oblique abdominal umseles, and the flanks should be round and deep. 'The hips should be wide and round, the loius broad, and the baek straight and flat. The tail shoult be broad and well-haired, and set on high, and fall abruptly. The breast shonld be broal; the fore arms short and museular, tapering to the knee; the legs straight, elean, and fine-boned. The thighs should be full and long, and close together when riewed from behind. The hide should be molerately thin, with a mellow feel, and movable, bot not lax; and it should be well eorered with fine soft hair. The nostrils slould be large and open; the eyes animated and prominent; the horns elean and white. 
The $0 x_{1}$ - In the $o x$, the masculine characters, so promincnt in the bull, are softened; the ncck is carried nearly straight from the top of the shoulders, without an arch; and the general frame is lighter, but the points of excellenec are the same.

The Cow.-Cows of a coarse, augular, gaunt figurc may give good milk, anl that in abundance, as, indeed, was the easc with some of the old unimproved brecds; but it is desirable, and moreover it is possible, to unitc qualities as a millker with such an aptitude to fatten as will render her valuable when dry, and profitable to the butcher. In a cow thus constituted, the head inust be long, ratlier small and fine; the neck thin and delieate at its junction with the head, but thickening as it approaches the shonlder and descends to the eliest; the breast sliould be at least moderately broad and prominent, with a small dewlap; the chine should be full and fleshy; the ribs well arehed, and the chest barrelled; the back straight, the shonlders fine, the loins wide, the hips well formed and rounded, the rump long; the udder should be moderate, with a fine skin, and of equal size both beforc and belind; the teats should not be too large or lax, and they sloould be equi-distant from each other. If the vascular system be well dercloped, the milk-vcin, as it is termed, is generally la ge; and thongh this vein is not connected with the uilder, but earries the blood from the foreparts to the inguinal vein, still it has been taken, and with some justicc, as the criterion of a good inilker. The eyes shoulel be clear, calm, and tranquil, indieative of a gentle temper; the skin thin, but mellow; and the hair soft. Cows thus admirably formed will often yield fiom twenty to twenty-four quarts of milk daily, and some, in the spring time, in good pasturage, even thirty, or more. The milk may, perhaps, yield less butter in proportion than that of some otlier breeds of cattle; but it would appenr that, as the cow advances in age to her sixth and seventh year thic milk becomes richer; and it is well known that the extensive dairymen of London prefel a cow which has had a third or fourth calf, and is five or six years old, to a younger animal.

We are perfeetly aware that Mr. Culley ("Observations on Live Stock,") considers it as an impossibility to unite good inilkers with good fceders; for, he says, whenever we attempt loth, we arc surc to get neither in perfection:- "In proportion as we gain the one, in the same proportion we lose thic other; the more milk, the less beef; and the more we pursuc beef, the less inilk we get. In trutl, they secin to be two different varieties of the same kind, for very different uses; and if so, they ought most certainly to be differently pursued by those who employ them. If the dairyman wants milk, let him pursue the milking tribc; let him have both bull and cows of the best and greatest milking fanily he can find; on the contrary, le that wants feeding or grazing cattle, let him procure a bull and cows of that sort which feed the quickest, whererer they are to be found. By pursuing too many objects at once, we are apt to lose sight of the principle; and, by aiming at too inuch, we often lose all. Let us only leep to distinct sorts, and we sball obtain the prize in due time. I apprehend it has been much owing to the mixing of breeds and improper crossings that has kept us so long from distinguishing the most valuable kinds." Mr. Cilley 
wrote in 1807 , and since his day many improvenuents have taken plate in the breeds of eattle; and expericnce has proved, that the improved Yorkshire cow, in which the characters of the Durham and Holderness are iningled, unites the two qualities in high perfection.

Reproduetion, Rearing and Fattening.- The heifer ought not to be permitted to breed until over two years old; the reason is obvious. Iler own system before this period is not suffieiently matured for the tax upon it-a tax which will be paich not only by the dam, but also by her progeny, for both will suffer from a defieicney in nutriment, the whole of which is necessary for the growth of the former, which during the seeond year is rapid. If the bull be kept separate from the herd of cows, the firmer may regulate the sincession of calves almost at pleasure, so as to snit his pasture or his arrangements. The best time as it respects the mother, the calf, and the free supply of milk, is when the spring grass is begimning to sloot luxuriantly, affording a good and sufficient store of nutriment. It is true that veal and butter yield a better profit at an earlier period, but the breeder inust judge in points of this nature from eireumstanees. The period of gestation in the cow is generally stated as nine calendar months, or 270 dius; but there is often considerable variation of time. M. Tessier observes (in a memoir read to the Royal Aeademy of Sciences in Paris), that the shortest period, as far as his opportunities of observation enabled him to ascertain, was 240 days, the longest 321 ; the difference being eighty-one days.* This range of time is very extraordinary, and appears to depend on the care paid to the animal, and on its state of licalth; br which the developinent of the ealf is influeneed through the sanguiferous system of the mother. With respect to the bull, he does not attain to a due degree of strength till two years old, and is in higher vigor at three; but how long the breeder may keep him after that age must depend upon his own judgment, and a variety of cirennstances. The cow seldon pro. duces more than a single calf, sometimes, howerer, twins, and very rarely three. In the case of twins, if they be respectively male and female, the female is generally, but not always, mproductive.

It is sometimes desirable that the furmer should possess the power of controlling the ratio of the seres in the animals he breeds. The wonderful ratio in which they are produeed in natmre, is one proof of the all-wise provisions of the Almighty in making then snbject to eertain laws. Many investigations have been made to show how far this is within the control of man. A dairy-man is particularly interested in the production of heifer ealves, wherewith to increase his dairy stock; a grazier may be equally desirous of producing bullocks for large weight ts and summer grazing; while a breeder for sale mily be anxions to see a goodly proportion of bulls. How far he can control this production is a question of interest and importanee. IIofkener, a German, made some calculations as regards the human species, which tended to slow that where the father was younger than the mother, the proportion of male

* In the Bulletin des Sciences, by the Soc. Philomatique, Paris, 1797, M1. Tessier says, that out of 160 cows, some calved in 241 days, and five in 308 ; giving a latitude of 67 days.-See Sir F. Home's Paper on Phil. T'rans. Part 1, for 1822. 
births to females was 90.6 per cent.; when of equal age, 90 per eent.; but when the age of the father was greater than the mother, nine to eighteen years, it was 143 per eent.

Similar in prineiple was the experience of M. C. C. de Buzareurgnes, who professed to have the power of eortrolling the sexes in sheep; his prineiple being the sane as the above, viz, that vigor was favorable to fenale, and the eonverse to male births. For females he proposed to seluct young rans, and place thein in a good pasture; for males, three to five shear animals, and to place then in an inferior pasture. His experiment was snecesstul. In his female trial there were seventy-six female lambs produeed against thirty-five males; and, in his male trial, there were produced eighty males against fifty-five females. Anotlier trial was made by M. Cournucjouls. One section was put to young male lambs, and on a good pasture; the other on a poorer pasture, and with old rains. 'The result was, that in the first experiment there were fifteen males and twenty-five females, and, in the second, there were twenty-six males and fourteen females.

Buzareurgnes also showed that in several lots the approximations to male or female births, were also in the ratio of the ages of the animals on both sides. Thus, of the young ewes put to the young rams, the two-year old ewes produced fonrteen inales and twenty-six females, the three-year old gave sixteen males and twenty-nine females; whereas the four-year old ewes, to the aged rams, and on the poor pasture, produeed thirty-three males and fourteen females.

More than this is not known; but there is quite suffieient to indieate that the breeder possesses at least considerable power in eontrolling the proportion of the sexes, and that the more vigor he has of frame and food, the greater will be the proportion of females; and that the converse of this will hold equally good. There is enongh in the prineiple to deserve a trial.

We now proeecd with details deseriptive of the management of ea'tle, under the lieads of rearing and fattening. The first object being to secure a suitable breerling stock, and a provision for proper buildings for their aceominodation and slielter.

Rearing.- It is most advantageous to have the ealves drop in the early part of the year, that the young grass may be ready for them about the time of weaning. New milk is best for the young ealf for the first fortnight, when it inay be trained to feed upon other food, such as linseed-eake, or swcet liay; and when it will eat these freely, its allowanee of milk may be gradially redueed, and slieed Swedes or earrots added to its food. The cribs slionld be kept elean, the food regularly supplied, and the ealves themselves should always reecive kind and gentle trentment. l'erseveramee in such management will greatly aid the growth of the young animals; when kindly treated, there will be no restless exeitement on the approach of strangers, and they are easily managed when surgieal operations becone neeessary from disease or aceident. All graziers are fully alive to the iniportance of docility in all fatting animals.

After three or four weeks the male ealves may be eastrated, an operation attended with less risk and pain when done at an early age. It is 
advisable to keep the calves in separate cribs until five or six weeks old, after which they may be turued together into a comfortable housc, with suffieient room for exercisc. And when the pasturage permits, and fine weather is well established, they may be turned out, at first for a few hours only in the middle of the lay, to inure them to the change. $\Lambda$ s winter approaches, they nutust again have the shelter of a comfortable yard, and be supplied with roots mixed with straw-chaff. An addition of one pound of oil-eake in summer, and two pounds to their ordinary food during winter, will greatly assist their eondition and early inatnrity. The yards should, of course, be well sheltered and littered, and cattle of the sane age and size have separate inclosmres, otherwise the weaker beasts will be driven about by the master ones. In the spring the young cattle are again turned to grass, and the treatment continues in a similar manner until the cattle are fattened of at home, or are sold off for that purpose into other districts. By liberal fecding whilst in a young state, the cattle are kept in good conclition and rapid growth.

We belicve that food for calves may be prepared of a much more nutritious nature, and much more likely to be of advantage to the producers; some of these, on which we liave suceessfully reared calves for several years, we shall place before the reader :-

1. Whentmeal Porridge.-This is made in the following manner: boil two gallons of water, and mix a pint of fine flour with cold water, sufficient to make it into the consistency of a thiek cream. This should be thoroughly mixed, and put into a bowl capable of holding half a gallon; a small quantity of the lot water is added to the mixture, and stirred so as gradually to raise the temperature of the flour and watcr in the bowl, and prevent it from running into lumps. This is plunged into boiling water, and stirred until the whole boils again. 'This coagnlates the mass, and forms a thiek nutritions porridgc. It is a great improvement to the mixture if one-sixth part of old skimmed milk is mixed with it; which not only gets scalded itself, but very materially improves it. 'T'wo gallons of the mixture per day will be found suffieient.

2. Linseed Jelly combined with the milk, is a very valuable auxiliary. Wc oursclice have searcely tried the sced by itself sufficiently to be able to give a very decided opinion upon it; and we much prefer the pressed seed, in the shape of cake, crushed to a powder; and, for this renson, if we wanted to lay on the fat, we should give them the erushed seel, bceause its fitty matter would, when cooked, bc cusily assinnilated into animal fat; but when bone and muscle are to be formed, every ponnd of fattening matter in the food displaces other substanees ealeulated to build up the animal structure; for this reason we most approve of the jelly produced by the crushed cake. The proportions of the erushed cake to the water shonld be as follows:- to two gallons of water take two pounds of oil-cake bruised or crushed nearly to a powder, sprinkle it in the water, stir, and allow it to boil ten minutes. Cool with skimmilk, if convenient. A rich jelly-like mass, of the most nourishing kind, is produced, which shonld be given in a lukewarm state.

3. Broth Porridge.-This is a somewhat unnatural mixture; but it is often used very successfully, combined with other mixtures, for feeding ealves. The water in which bacon has been boiled is carefnlly preserved, 
and diluted with perhaps one-lialf of its quantity in water. It inay be expeeted that a substance like baeon, from which nitrogenized and pliospliorie matter may be expected to be dissolved by the action of boiling, will be of use; but, to make it alimentary, it is necessary to mix it with a considerable proportion of milk. However unuatural this mixture may appear; how eontrary soever to all theories of natural history it may be to give earnivorons matter to herbivorous animals, we may find in it an analogy by no means unimportant, in the disposition evinced by mature animals of this description to select and eliew, for hours together, a picee of bone, which they will seareh for with instinetive pertinacity, and relinquish with reluetanec. Is it not because sle finds in it the nitrogen or the plospliates denied her in the food upon which she is eonfined? And if this be so-if she is guided by her instinet to select and choose animal matter, why may not a decoction of animal substanee be useful to the calves, in their younger stages, as an auxiliary, and, to a eertain extent, a substitute for the beverage which nature has given them, but which man denies them.

Solid Food for ealves will soon, however, displaee mueh of the liquid. At five or six wecks old they onght to be trained to eat slieed roots. To do this it is only necessary to supply them in eonvenient forms in a trough within their reach. Their moments of leisure will be employed in playing with and steking these pieces, until they begin to mastieate thein. 'The roots should, for this purpose, bc eut into oblong pieces, one inch broad, half an inch deep, and two iuches long; these shapes are better than either slices or squares, being more adapted to their eonformation, and better ealculated to make them learn to eat of their own aecord. Calves should be reared from the months of Septenuber to Marel.. We do not approve of late-bred ealves; if they are reared late, they become tender and require nursing the following winter. In the months we have naued, however, turuips are always plentiful; or, if mangel-wurzel is enltivated, it will be found a very sueeessful substitute; although we prefer Swedes. These appear not only to agree with the palate of the animal and to make it thrive, but they exercise a very beneficial influence on its subsequent derelopment. Is it because they contain a large share of the phosphates? Sprengel makes the relative proportions of the phosphates in the Swedes to be nearly six tiues as great as in the eommon turnips, and sulphate ten times.

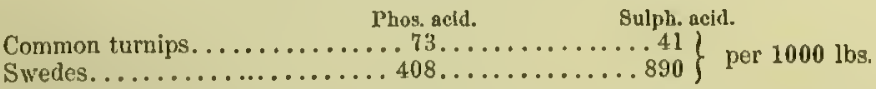

Other auxiliaries are sometimes adopted, such as beall-meal, pea-meal, oatmeal, eattle sago, and Indian meal; all these being very material aids in rearing calves.

CATTLE-FEEIIIY,-This question is one of econorny simply: how can the laryest number of pounds of beef be produced at the least possible cost? 'This is the real question still unsettled, and on this we will proeeed to slow the present extent of our knowledge.

First. The grazier must select suel animals as will lay on fat rapidly; and, by a plysiological law, as we have seen, there are those which will 
soonest attain maturity so as to be fit for feeding. We stop not now to examine whether or not the two principles of taking on fat early as well as rapidly are necessarily connected-though it is very probable they are-and that a tendency to lay on fat will show itself at a very carly period of the animal's history; though it may possibly be a mere result of the breeder's skill to obtain the two qualities combined.

Now, every good grazice knows an animal which will thrive, that being a simple matter of judgment. A skillful man will select out of a drove, five, or ten, or twenty animals, and nineteen of the twenty will be the best grazers for his particular farm. The eye guides him partially-the signs we have described in our remarks on the breeds of eattle also-but more than all he is directed by the touch.

Having selected the animal, the mode of feeding him is to turn him out into a grass field skirting a river-if such be within the grazier's power-where alluvium of ages has been washed into the soil so deep that the roots of the herbage cannot find its bottom, and so firmly comminuted as to admit of the ininutest filaments of the radieles of the plants to penetrate it with facility, so porous as to admit the air to enter, and the water to filter gently through, and containing its elements in a state of solution so delicate that they are realy for food to the plants which consume them; but last, though of greater importance than all, having the elements of vegetation in plentiful abundance. Now, all men know that on suels a soil, in five, six, or even in four months, a lean animal will beeome fat. Ile has all he requires-a little attention to see that he is well is all that is needed, from the time of his being placed in the pasture to being taken out to the butcher. There is neither labor, pains, or expense incurred. Ile is worth twenty-five dollars more when he is taken out than when he was put in, and that is all the grazier knows or eares for. Now, we shall find out the requisites here for feeding, strietly laid down. There is plenty of fresh and highly nutritive food; there is scarcely any labor in searching for and obtaining it; with water, and shelter, and warmth; and also plenty of air, and
freedom from eonstraint.

Now, this is what the feeder must aim at in his winter-fed cattle. They cannot feed in the open air; the cold and wet would deprive him of the flesh as fast as the food laid it our. IIere he unust provide shelter. Now, one of the controversies of cattle-feeding in winter is, which is the best mode of providing this. 'The Scotch farmer loudly eontends for full and perfect liberty to the animal. If lie is too warm he will sweat, and if too closely confined lie will fret and murmur; and he declares that practise has decided that they should be fatted in open places; a sheltered shed they may have, but nothing beyond it. The midland counties man says this exposure is dreadful. It wastes their beef, and renders them subject to disease, and involves long feeding. Another class agiin insist on the tying up of the amimals as injurious to their healtl; t that a little exercise, but absolute confinement, are equally necessary; and that they should have shelter with freedom-these two elasses are controverting the merits of box and stall-feeding.

And both of them are right. Take a Ilighland Scot, consider his wild habits, his long stray of mountain and glen, his wide-spread pasture
$6^{*}$ 
of peat and heather, from which he could in his native fastness smell afar off his friend or his cnemy man! Tie him by the head and he becones fretinl or furious; he will pine, and fret, and worry limself; while, in his gregarions state, with a herd of his fellows in open yards, or slreds, he will thrive. Nay, he has a nature which will lay on fat despitc the cold and wet, as the rye among plants can assimilate food from the barrenest soil; so he lias a natural shelter in his hair and constitution, for which the owner of more delicate and tender animals will not give him eredit, forgetting that the Scotchnnan has a different aninal to deal witls in his shed-feeding from the short-horn.

The short-horn feeder, on the contrary, possesses a tame, quiet, gentle, lethargic animal, which shows that universat mark of good breeding in men and animals-he is always quiet. He will neither pinc at nerer beholding the light, nor feel the want of exereise if he ncver leaves his stall, provided he has food and comfort in plenty. Nay, he will bardly take the exercise necessary to keep his limbs in healthy action. But keep him from the eold and wet; prevent the blast from passing over him; he likes protection, and thrives best in boxes.

Take a Devon, or, if you like, a Sussex ox. He is large and cumbrous; but he is active. Give him liberty, and he will roam and harass himself; but he is tane cnongh to keep to his stall without pain or fletting. He requires a stall.

The Temperature at which it is desirable to keep feeding animals is a matter of more importance than might he inferred from the apparently small amount of investigation bestowed npon it. The question is, are we to jun the risk of a wasting cxpenditure of food by perspiration umler excessivc heat? or are we to induee them to waste it, to keep up animal heat, by exposure to ton much cold? Nay, will not different elasses of feeding animals be subjeet to diflerent eonsequenecs, from the same derree of lieat? In the same cow-liouse there may be some too hot, and others too cold, from their different eonstitutions. Oxen generally sweat at a temperature in whieh lucifers thrive admirably; this happens at any ratc till C'hristmas, after which they seem to be able to beal the same degrec of lieat as female animals.

H. S. 'l'hompsou, Esq., tied up two sets of fucding bulloeks, eiglit into a warmer shed than the rest. They had the sane quantity and kind of food; but those in the warmer shed made more beef than those in the eolker, showing that warm air, as well as warm food, was lighly favorable to fattening short-homs; which breed, we believe, he invariably fittens. The temperature he aims at is about $55^{\circ}$ to $60^{\circ}$ of Fahrenheit; an inerease of this caused them to get off their food, and lose their tone and appetite.

Stillness, with the limitations given in our rcmarks on shelter, is necessary to suecessinl feeding. This is well known to geesc feeders, who even nail them to the boards; and it was shown very strikingly by Mr. Childers, M. P', in his experinents on shed-feceling, and by Lord Batliurst, on stall-feeding shecp. An animal in the very effort of searching and securing his food, expends the principle neessary to make fat; henee it is necessary that his turnips be brought to him instcad of driving him to the turnips. They are cut and placed beforc him, that he may have 
as little effort as possible in the operation of chewing, and he has anple allowance of room, so that when lie las fed, he may lie down and sleep.

It is a question whether animals feed fastest in the dark or not. There can be no doubt whatever that any thing which distracts their attention, which exeites aetion, or which produces nervous irritation, is opposed to fattening; and, as darkness will induce sleep, inartion, and promote quietness, it is so far favorable; but it is not so eaky to have darkness and sufficieney of fresh air at the same time, and therefore the best possible state, perhaps, is to lave the feeding-lonses rather in a state of shady gloom than in absolute darkuess. A eertain amount of nervous energy is neessary to give tone to the vital powers, and, beyond this, repose and quietness are easily attained by a simple glooin, while shelter from flies and lieat in summer, and from blasts, wet, and extreme cold in winter, should be earefully provided.

Alundance of food Food and Regularity of Feediug, are essentials in all kinds of fattening. Though it is not desirable to allow the animals to have food standing before them when they are filled, they should never, on the other hand, experienee a single feeling of want. The usual hours of feeding should be strietly adhered to, for the two-fold purpose of indueing regular periods of sleep and for supplying the system with food at the first eall of appetite.

Variety of Food is a most essential element of rapid fattening; and it is not far from the truth to say that all kinds of food are equally fattening, if they are given in suffieient variety. If roots, grain and hay be ehanged every few days, the appetite is never eloyed; and the whole are devoured with a relish which develops fat in the most rapid manner.

The Formation of Fit is the work of the grazier. His animals are generally tull grown, or nearly $\mathrm{so}$, and, though there may be a small increase of musele, still the bulk of the material of inereased weight is fat and not fesh. In this country, food to be palatable-to be consumablemust be fat: unless it has this recommendation it is absolutely mnsalable. The appetites of the higher and the neessities of the lower elass, urge on the demand for fatted beef, mutton and pork; and any brought to market in a state other than fat, is looked upon as earrion. Hence the grazier nust supply the whole of his animals in a fat state to the consumer; and therefore it is not the number of animals, nor their weight he has to consider, but he has to provide for them the means of fattening before they ean be brought to the consunier.

'The saceharine inatter' of vegetables, and their stareh, will supply the means of fuel-food; the fatty matter will produce ready-formed fat to deposit; and the albuminous matter will afford the flesh which waste is continually throwing into the exeretory system, and for the small andditions which may be necessary to earry the requisite amount of fat.

It is not not our intention to enter into the dispute between the two sehools of physiologists, as to whether the fat was formed by transmutation of the sugar and stareh of the food, or whether it consisted of the ready formed fat of the food on which the animals fed. Withont for a moment pretending to settle this point, it is at least desirable so far to supply both saccharine and fatty matters, as to give the system the choico of selection. 
Preparation of Food for the animal's stomach, or a system of eooking, is a very important question. Steaming hay, potatoes and turnips, has been tried very carefully in Scotland, and failed. For cattle, at least, it is useless; how valuable soever it may be for pigs. It is pretty certain, however, that, with certain combinations, all that a feeder ean desire is attained by the cooking of flax-seed.

The fat of animals is strictly analogous to vegetable oil; its elements are much of the same elaractel as sugar, stareh and gum, and no doubt is entertained, by physiologists and chemists, that the fatty matter (vegetable oil) in plants, is assimilated into animal fat, with but little ehange. The elements of those compounds severally are:-

\begin{tabular}{|c|c|c|c|c|c|}
\hline & Sugar. & Starch & Gum. & Mucilage. & $\begin{array}{l}\text { Animal fat } \\
\text { (stearine). }\end{array}$ \\
\hline Cark & 12 & 12 & 12 & 24 & 71 \\
\hline Hydrogen ............... & 11 & 10 & 10 & 19 & 69 \\
\hline Oxygen $\ldots \ldots \ldots \ldots \ldots$ & II & 10 & 10 & 19 & 7 \\
\hline
\end{tabular}

The oil eontained in many seeds is given by Professor Johnston -

Oil per cent.

Flax-sced......... 11 to 22 say 17

Hemp-seed ....... 14 " 25 " 19

Rape.seed .......40"70" 55
Wil per cent.

White mustard ......36 to 38 say 37

Sweet almond ......40" 54 " 47

Bitter do $\ldots \ldots .28$ " 46 " 37

This would naturally indicate that any of these seeds would, so far as they were palatablg, be useful; and when linseed contains as much as seven per eent. of mueilage, ten per eent. of sugar, and fifteen of soluble albumen, it is elearly indieated as being a seed most valuable for feeding and nourishing purposes.

Varions attenipts have been made to adapt it to the feeding of cattle. There was some diffienlty in grinding it by ordinary mills, as it elogged up the teeth; and when given to animals either alone, or eombined with considerable quantities of coln, meal, or other feeding nuatter, the effeet on the animals was purgative, and but few breeders persevered in the use of the seed alone. The demand for the oil, however, induced the erushing of the seeds to obtain it, and the refuse left was found to be very valuable as feeding material; while the portability of oil-eake, its eleanliness, and eapability of being long kept, made it a general and desirable food, both for growing and feeding stoek. The oil abstraeted, the eake contains, aeeording to the same authority:-

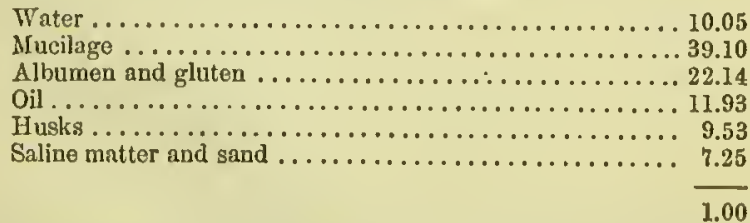

We do not see exaetly how the eake ean eontain so large a proportion of oil relatively with the seed; but it is probable that the seed had originally eontained a large proportion of oil, and that it had heen but indifferently erushed. Good English-made eake, however, has been 
thoroughly established as one of the best of fattening produets; and the extensive farmers of Lineolnshire and other plaees expend upon a single farm, in one year, as much as $£ 400$ to $£ 500$, for this artiele of food; and so well understood is its fertilizing charaeter, that many land-owners are willing to make themselves and their ineoming tenants, chargeable with proportions of the money so expended, at the rate of one-half to one-third. It is the opinion of some of the best farmers, that when eake can be purcliased at the same price per ton, in pounds, that beef and mutton can be sold at per stone in shillings, it will be paid for in the eattle and animals fed, without referenee to the manme.* The priee of cake, however, depends on $n$ such element of ealeulation; the demand for it has inereased far beyond that of the oil, and in some scasons it has been so great, that the former beeame an object of eommeree rather than the latter.

Attempts have beell oeeasionally made to render the unerushed seed arailable by a cooking process, but it has been generally found more adapted for calves than for store stoek or for fattening; where used at all for the latter purpose, it has only been to supply a defieieney in turnips.

The most deeisive stcp, however, in the use of eooked linseed, was taken by Mr. Warnes, of Trimmingham, near North Walsham, in Norfolk, in 1841, when a discussion was appointed by the Farmer's' Club there, on feeding cattle with linseed eake. Mr. Warnes commeneed by inquiring into the nature of cake. He immediately commenced a series of experiments with flax-seed in various forms-both crushed, steeped, boiled, and eooked in various ways. He also tried the boiling of barley and other food on various aninals. He ultimatcly adopted a mode of feeding, on what was called by him flax-seed compound. He carried out, in eonnection with his experiments, growing, dressing and preparing the flax, the feeding of cattle with the prepared seed iu boxes as antagonist to tying up, and the smmmer grazing of eattle by soiling.

Ifis eooking apparatus is so simple, that it is managed by a blind man, whose happy eonntenanee bespeaks neither over-weeniug anxiety, nor unremunerated toil. The apparatus consists of two cast-inetal boilers, fixed in brick, and liaving a fire-plaee beneath them; the water is made to hoil before the flax-seed is put in. The seed is eruslied by a very powerful implement, consisting of two eylinders, one of them being of large diancter; they are made to press upon eaeh other in their revolutions by two lunar springs, and two men will thorouglaly grind two bushels in ten minutes; at this rate the men are able to work the whole day. The mill is, however, eapable of being reduced to the eapaeity of one man. The erushed flax-seed is sprinkled upon the boiling water at the rate of one gallon of seed to cight gallons of watcr; great stress is laid on sprinkling the seed very gradually, otherwise it is apt to adhere in lumps, and eleave to the sides or botton of the boiler. With this preeation, however, Mr. Warnes assures us he has had no instanee, for several years, of this occurrenee. This misture is boiled six minutes, and for that period is slightly stirred; at the end of that

* The pound storling is $\$ 4.85$; the shilling is 24 cents; the stono woight 14 lbs. 
time it is found to be a thick gelatinons mass. In one minute after this the unass beeame more mucilaginous, and was improved. Nine busbels of eut pea straw were then placed very gradually, and by one busliel at a tine, in a tub twenty-eight inches high ; the liquid jelly was now taken out in a scoop, poured upon it, and as each addition was mate the whole was rammed down by a kind of beater, more for the purpose of mixing the mass, and confining the heat, than for any other olject. The present cost of the animals in flax-sced is 3s. per head per week. In addition to this, they have also about one bushel of eut Swedes per day.

Ifr. Warnes occasionally mixes his compound with meal. This, when used, is also sprinkled over the boiling mueilage. So soon as the first boiling was nearly emptied from the boiler, it was again filled with water, and was ready for another boil, when required.

As a test of its value, Mr. Warnes furnislod the following remarks and experiments illustrative of the effects of his system: "Flax-seed," he says, "has five essential properties, nanely, mueilage, oil, albumen, gluten and sugar. 'The shell, or exterual er'ust, is the hardest of all seeds, and the most diffienlt to break in pieces; but not too hard for the miller, who has every partiele ground almost to powder, in order that all the oil may be expressed, which it could not be if coarsely crushed. This is denonstrated by the eake, in which the presenee of seed is seareely apparent. To a sinilar state seed for the eattle compounds ought to be reduced; otherwise some, at least, of the properties above deseribed will pass off without benefit to the fattening animals. This the scientifie grazier will discover by the exerements, in which he will find suffieient cause for griuling, not only flax-seed, bnt all grain or pulse, if possible, into flour. From researches like these the profitable returus for grazing upon iny premises, may be dated." The expenses of this copper, with the whole working apparatus for eiglity or one hundred head of stock, will not be more than four pounds.

A part of Mr. Warnes's system is the feeding in boxes, the growth of flax-seed, the manufacture of the fiber into tlax, and the soiling of cattle with green food and compound in summer. It would swell this article much beyond its legitimate limits, if the box system were more fully deseribed. It may suffiee to say, that the boxes at Mr. Warnes's have been put up very eheaply - they form two sides of what has formerly been a fold-yard. The sides have had a roof put along the wall, supported by pillars of woorl, and divided by rails of any ordinary wood; the front next the yard being inclosed by two gates. The box is eight feet six inehes square; and adjoining the wall is a passage from which the food is given in troughs, which are made to slisle up or down as the manure accunulates. The manure is never carted ont until it is taken to the fields; and, as the boxes are walled for one foot from the bottom, there is not the slightest eseape of the liquid manure or of the ammonia, and therefore it is peenliarly rich, from this cireninstance and from the stimnlating food supplied to the fittening animals.

Much has been said as to the dirt and filth, and unnatural state of the animals; but their condition is preeisely the reverse, in every respect; they are quiet, have excrcise sufficient for healthy secretion, can feed at 
leisure, and, whencver we observed them, they were elean and free from smell, and every thing objectionable. The fuct of the trealing, and thorough consoliclation by the animals' fect, prevents fermentation, and the conseguent evolution of gases which would take place if mere stall-feeding were practiced. On the whole, we think there are many more valid reasons in farol of than against box-feeding.

The direction given to men's minds by the expcrinents of $\mathrm{Mr}$. Warnes, induced trials with all kinds of modifications of flax-sced cooking; but the one which has obtained the greatest amount of favor is that adopted by Mr. Marshall, near Thirsk. The great difference bctween Mr. Marshall's plan and that of Mr. Warnes, is, that the inaterial cooked has not the heat applied to it directly, but to the outside of the boiler in which it is to be cooked, so that no direct application of the fire slatl take place to burn the mucilaginous matter. Mr. Marshall insists that, to eook the material properly, it must be boiled at least two hours.

Ilis mode is this:-one pound of flax-seed is boiled for two or three hours in about one and a half gallons of water. Five pounds of straw are chopped, say one inch long, and mixed with two and a half pounds of ground oats or barley uneal very intinately, which is then placed on a tloor of flags of brieks, and the boiled seed poured upon the mass, and turneel, and then allowed to eool one or two hours, when it is given to the eattle.

The cost of the apparatus or fitting will be about $£ 50(n)^{\circ} \$ 250$.) On the whole we think it very desirable to adopt one or the other process in all situations where an inereased quantity, and better quality of mamre is a desideratum, not to mention the more profitable returu, as exhibited in both the systems described.

$\mathrm{Mr}$. Warues, altogether unprejudiced in favor of his own peculiar system, has been experimenting on the mode recommended by some graziers, of steeping the linseed-meal in eold water for some twelve or fourteen hours, - when a slight mneilaginous deposit was the result. The experiment will no doubt he carefilly and accurately made under his direetions; but, we confess, our prepossessions are in faror of the cooked materials.

The following is a plan of Mr Warnes's shed boxes for cattle-feeding:

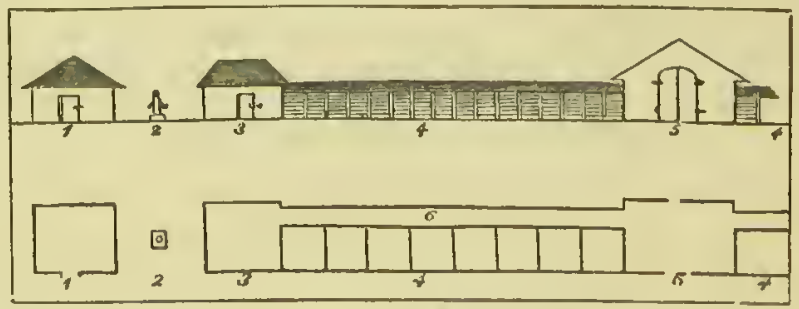

1. Cooking-house, 20 by 16 feet.

2. Pump.

3. Storeliouse, for roots, \&o.

4, 4. Boxes nveraging mil square fect ench.

b. Forder-house, with tank under the floor.

6. Passige, 4 feet.

Mr. Thompson, of Moat Hall, Yorkshire, a most skillful and acenrate 
investigator, made some very important experiments as to the relative value of hot and cold preparation of flax-seed. He took two animals, and fed the one on hot and the other on eold food. He had both weighed before he started, and both again weighed at the expiration of six weeks. The aninal fed on cold food weighed, when put up, 107 stone $11 \mathrm{lbs}$. (1,509 Ibs.); that fed on hot, 108 stone 7 lbs. (1,533 lbs.) At the end of six weeks the first laal gained $40 \mathrm{lbs}$; while the last, the one fed on lot food, had gained $\mathbf{r} 1 \mathrm{lbs}$. To guard against the one having any speeial aptitude to fatten whieh the other did not possess, he reversed the order; and then it turned out that the animal now fed on cold food, and before on hot, gained 53 lbs., while the other, now fed on hot food, gained $71 \mathrm{lbs}$.

But not only on the animals did the results of eooked food show itself in this striking manner; for, while one fed on hot food had only $80 \mathrm{lbs}$. of Swedish turnips per day, the one fed on eold food was not satisfied till his feed was increased to $87 \mathrm{lbs}$. of turnips in the sanc time, showing a greater eonsumption of other food to makc up for the want of heat!

Food as Allectiug the Quality and Qunutity of Milk.-Messrs. Dumas and Bonssingault tried a number of very eareful and interesting coperiments on the quantity of milk and its produets which would be given by eows fed on different kinds of food. They tried nearly all the eombinations usually given, except perhaps bean meal, and the result was, that the greatest quantity of milk was given when the cow had green clover, in every ease, i. $e$., that in each instanee this yielded the greatest quantity of butter, and, with one exeeption, the greatest produee also of cheese; and that exception was when the eow had bcen but one day ealved, which would aecount for the abundanee of eheesy matter in the milk. The table is so instruetive, that we will quote one or two of the items :-

\begin{tabular}{|c|c|c|c|}
\hline Days after cal ring. & Milk. & Butter. & Cheese. \\
\hline Potatoes and hay & 9.3 & 4.8 & 3.3 \\
\hline Hay and green clover ........... 182 & 8.9 & 4.5 & 4.0 \\
\hline Green clover ................. 193 & 9.8 & 2.2 & 4.0 \\
\hline Clover in flower .................. 204 & 7.8 & 3.5 & 3.7 \\
\hline Potatoes ..................... 229 & 5.0 & 4.0 & 34 \\
\hline Turnips ........................ 207 & 6.0 & 4.2 & 3.0 \\
\hline Red beot.................... 215 & 5.6 & 4.0 & 3.4 \\
\hline
\end{tabular}

Into their philosophical investigations and reasonings we shall not enter. Mangel-wurzel, bean meal, and grins, much increase the milk.* Good hay and oat mash mueh inerease the butter, and turnips, though they give a disagreeable flavor, greatly increase both.

To keep the cow as long as possible in mill is sometimes an object. Some eows dry early,-sone may be milked throngh, thongh always with disadvantage to both the eow and the calf; both lieing fueble and impaired, if it is persisted in. In summer weatlier, however, wlyen cows are very deep milkers, and in ligh condition, it is not only sometimes

* Indian meal fed in cool weather, while it is a higlily mutritious food, also adis greatly to tho quautity and quality of tho milk. The erroneous prejudice against its use for milch cows has beon fully refuted by careful experiments. 
advisable but absolutely necessary. A cow not put to the bull will hold to her milk much longer than one whieh is regularly breeding.

THE DHIRY - BUTTER AND CIIEESE IIAIIYG, - In all dairy establish ments ventilation and eleanliness are iudispensable; and if butter is made, the dairy proper, or butter-room, should be as near the cow-house as possible, as the milk suffers more or less considerably from being agitated, or too much cooled, before it is set for the erean to rise. 'The milk should be brought from the eows without being exposed to the outer air, before it is set to erean; which should be in vessels arranged on a stone slab, below the level of the ground; the apartment being sunk to the deptin of three or four feet, and kept perfectly diry. 'The air may be admitted through perforated zine plates, or woren-wire windows, placed opposite to each other, having shutters which may be opened or elosed according to the temperature and state of the weather. Glazed windows may be added, and should be open, excepting in very hot or very eold weather. The situation should be dry, and well shiclded from the north, east, and south.

The Dairy-House is, perhaps, of all other applianees, the one on which sueeess most depends. It should be apart from all household operations, from open grates, and from dung-heaps, and should have as much as possible the means of an equable temperature. As, however, it is much easier to keep a cold building warm, than to eool a hot one, it is desirable that it should be as much as possible shielded from the sun's rars. It should have its side to the north, its end to the east, and should, if possible, be let into the earth a few feet, but not so deep as to interfere with the drainage. If eovered by a large tree it would be all the better. Around it should be either a hollow wall, or peat earth should be walled round its exterior; or, as another alternative, and possibly the best but most expensive, it should be surrounded by a veranda. It should also have a double roof, and abundant top and side ventilation-either of which should admit of being closed. It is necessary to have in it a pump, the floor sloping, and on the highest part a perforated pipe should be connected with the pump, to allow of the cleansing of the floor with cold spring water when neessary. The bowls should either be earthen-ware or glass dishes, placed upon wooden tables-fir, maple, or syeamore are the best; or leaden bowls may be used, placed on frames, and surrounding the dairy. Stones are the best for the floors, and a lining for the walls of white pottery is not only elegant but useful; a pipe connected with the boiler attached to the kitchen fire is a great advantage, with a stop-cock, so as to regulate the heat of the room in winter. The scalding and churning rooms should be distinet from the milk-house, and the latter should be kept as free as possible from all kinds of forcign matter. An outer veranda is useful for drying the dishes and pails, and therefore desirable, when the dairy is suffieiently extensive to render the expense of its erection judieions.

Butter is the fat or oleaginons part of the milk of varions animals, prineipally of the domestic cow. 'The milk of the eow is composed of three distinct ingredients - the curd, the whey, and the butter; the two first form the largest portion, and the last the most valuable. The conparative value of the milk of different cows, or of the same cows fed on 
different pastures, is estimated ehiefly by the quantity of butter eontaincd in it; and in this respect some breeds of eows are far superior to others. The union of the component parts of milk is chiefly mechanieal, as they separate by subsidence according to their spccific gravities, the cream being the lightest, and the curd the heaviest; the eurd, however, requires a slight ehemieal change for its separation from the whey, which at the same time produees a peculiar aeid, called the laetie acid. From the moment that milk is diawn from the cow, it begins to be affected by the air and changes of tcmperature, and eireumstanees alinost imperceptible to our senses will inaterially affect its quality; henee the importance of extreme care in every step of the proeess of the dairy, especially in making butter.

The cows should be milked in the cool of the morning and evening; they should not be much driven immediately before milking, and it is best to bring them to the plaee of milking some time before the operation begins. In some situations it is better to milk them in the pastures and carry the milk home; in others to drive the eows gently to the eow-stalls. In mountainous eountries the first mode is generally adopted, because the eows are apt to leap down steep plaees, and shake the milk in their udder more than is done by earrying it in the pail. The same practice holds good in Holland from another eause, which is the distanee of the pastures from the home-stalls, and the facility of transporting the milk in small boats, all the best pastures being surrounded by small eanals eommunieating with the greater; thus the milk may be carried several miles withont the least agitation.

As soon as the milk is brouglit into the dairy, it is strained throngh a fine sieve or eloth, and it is then ponred into shallow pans or troughs lined with lead. The best pans are of metal, either of iron, carefully tinned, or of brass. Such pans are cool in summer, and in winter allow of the applieation of heat, which is often very uscful to make the cream rise. When leaden tronghs are used, they are generally fixed to the wall, and have a slight inelination toward one end, where there is a hole with a plug in it, by drawing whieh the thin milk is allowed to run off slowly, leaving the eream behind, which runs last through the hole into the pan placed under to receive it. The milk in the pans or troughs is generally four or five inehes in depth, whieh is found most eonducive to the separation of the cream. The plaee where the milk is set should have a thorough dranght of air by means of opposite wire windows. The sun shonld be earefully exeluded by high buildings or trees, and the floor, whieh shonld always be of briek or stone, slionld be continually kept moist in sumıner, that the evaporation may produce an equal, cool temperature. A small stove in winter is a great advantage, provided smoke or smell be most carefully avoided, and thc temperature be earefully regulated by a thermometcr. In Switzerland men are ehiefly employed to nilk the eows, and in all the process of the preparation of butter and elieese. The women only elean the utensils, and carry green food to the eows when they are kept in the stable. When the milk lias stood twelve hours, the finest parts of the cream have risen to the surface, and if they are then taken off by a skimning-dish, and immediately ehu'ned, a very delicate butter is obtained; but in general 
it is left twenty-four hours, when the eream is collected by skimming, or the thin inilk is let off by taking out the plng in the troughs. All the eream is put into a deep earthen jar, which should be ylazed, but not with lead; stone-ware is the best. More eream is added every day, till there is a sufticient quantity to churn, which in moderate dairies is every two days. It is usual to stir the ere:um often, to encourage a slight acidity, by which the proeess of ehurning is accelerated. This acidity is sometimes produeed by the addition of winegar or lemon juice; but however this may facilitate the conversion of the eream into butter, the quality is decidedly injured by it, especially butter which is to be salted. It has been asserted by some authors that butter will not sepalate from the buttermilk until aeidity is produced, and, no doubt, there is more or less of lactie acid in all buttermilk; but perfectly fresh eream, which has stood only one night and is ehurned early next morning, will generally produce excellent butter in a quarter of an hour or twenty minutes in summer, and no acid taste can be discovered in the buttermilk. The ehange by which the butter is separated in a solid form is aceompanied by the development of heat in churning.

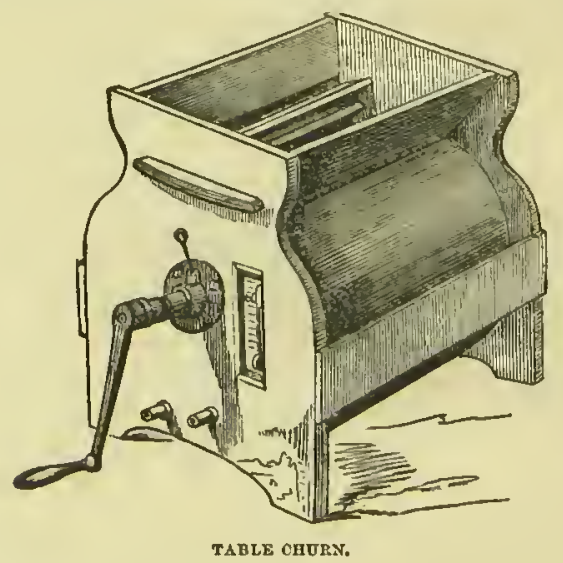

Churn.-As to the form of eliurn there may be a variety of opinions. The ultimate object is to secure that form which will facilitate a rapid, steady, and shaking pressure of the eontents; and this is effected either by a flapper, driven through the eream, at a considerable rate, by means of a piston with a perforated base; by a perpendieular motion, raised up and down in a eylindrieal or similarly formed vessel; or, what is more common, and by no means the worst form of churn, a eylinder studded with per irated beaters, fastened to its inner surface, and revolving round its two axles, admitting of one handle or two, aceording to the quantity on the eream. By this means the specifie gravity of the cream, as well as the foree and impetus of the machine, are both brought -into play to excite the lieat, tl: pressure, and the agitation necessary to the proper and speedy deve' pment of the butter. To this horse or 
steam power may be easily attached, and though there have been many forms of ehurn in use, we are not certain that any very great improvement on the above form has so far been discovered. I'lans have been adopted to diminish the labor, but this has often ended in defective operation. The American and the table churus, available for the extemporaneous manufacture of butter every morning for the tables of the rich, are so far a step in advanee, and a luxury; but for the large operations of the dairy-farmer, a better application than the churn of his torefathers has not yet been discorered.

Sonse experieneed dairy-men pretend that the buttcr is deteriorated by much washing, and therefore they express the butternilk by simply beating the butter with the hand, kept cool by frequently dipping it in cold water, or with a moist cloth wrapped in the form of a ball, which soaks up alt the buttermilk, and leaves the butter quitc dry. This operation requires the greatest attention, especially in warm weather, and no person shonld work the butter who has not a cool hand. The less it is handled the better, and therefore a wooden spoon or spatulat is much to be preferred.

When it is entirely freed from the buttermilk, and of a proper consistency, it is divided into portions of the wcight required, if it is intended to be sold fresl. But the grentest part of the butter that is made, especially at a distance from large towns, is immediately salted and put into casks, which usually coutain fifty-six pounds, and are called firkins. The quality of the salt used is of great importance; if it be pure, the butter will keep its flavor a long time; but when it is impure, and contains bitter and deliquescent salts, the butter soon becones rancid. The Dutch are very partienlar on this point. They use a kind of salt which is made by slow evaporation, and perfectly crystallized. The salt is intinately mixed with the butter. From three pounds to five pounds is suffieient for a firkin of tifty-six pounds. ${ }^{*}$ The casks are made of clean white wood. They are carefully washed insicle with strong brine made hot, and rubbed over with salt. The butter, being quite dry, is pressed elose into the cask, a small layer of salt having been first put on the bottom. Every addition is carefully incorporated with the preceding portion. If there is not a suffieient quantity to fill the cask at once, the surface is made smooth, some salt is put over it, and a eloth is pressed close upon it to exclude the air. When the remainder is adderl, at the next churning, the eloth is taken off, and the salt, which had been put on the surfice, is carefully removed with a spoon. The surface is dug into with a small wooden spade, and laid rough, and the newly-salted butter is added and incorporated complete1y. This prevents a streak, which would otherwise appear at the place where the two portions joincd. When the cask is full, some salt is put over it, and the bead is put in. If the butter was well freed from all the buttermilk, and the salt mixed with it was quite dry, it will not shrink in the cask, and it will keep its flavor for a long time. Should

* The follow $\mathrm{g}$ mixturo has been found superior to salt alone in curing butterhalf an ounce if dry salt pounded fine, two drachms of sugar, and two druchms of saltpetre, for every pound of butter. 
there be an appearance of shrinking, the cask must be opened, and melted butter poured round it so as to fill np the interstices between the butter and the cask. There is a mode of prescrving butter for domestic use without salt, in the following manner: the butter is set in a clean pan over the fire, and melted very gently; it is not allowed to boil, but is heated very nearly to the boiling point. Experience has shown this heat to be attained when the reflection of the white of the eye is distinctly scen on the surface of the butter on looking down into the pan. All the watery particles are then evaporated, and the curd, of which a portion always remains in the butter, and which is one cause of its bccoming rancid, falls to the bottom. The clear butter is poured into an earthen vessel and covered over with paper, and a bladder or a piece of leather is ticd over the jar to exclucle the air. When it is cooled, it much resembles hogs' lard. It has lost some of its flavor, but it is much superior to salt butter for culinary purposes, and especially for pastry.

The Devonshire method of making butter is peculiar to that county. The milk, instead of being set for the cream to rise, is placed in tin or earthen pans, holding about eleven $\mathrm{or}^{\circ}$ twelve quarts each. Twelve hours after milking, these pans are placed on a broad iron plate, heated by a small furnace. The milk is not allowed to boil, but a thick scum rises to the surface. As soon as small bubbles begin to appear, where a portion of this scum is removed with a spoon, the milk is taken off and allowed to cool. The thick part is taken off the surface, and this is called clouted cream ; it is a sweet, pleasant substancc, more solid than cream, but not so solid as butter, and is generally considered a dainty. A very slight agitation converts it into real buttcr, after which it is treated exactly as we have before described.

Another method of making butter, which is more generally adopted, is to churn the milk and cream together. This method is pursued in parts of Holland, Scotland and Ireland, and is said to produce a greatcr abundauce of butter from the same quantity of milk. In the Dutch method the milk is put into deep jars in a cool place, and each meal, or portion milkel at one time, is kept separate. As soon as there is a slight appearance of acidity, the wholc is churned in an upright chmm, which, from the quantity of milk, is of very large dimensions. The plunger is worked by machinery noved by a horse, or sometimes by a dog walking in a wheel, which he turus by his weight. Wheu the butter begins to form into small kernels, the contents of the chnin are emptied on a sicve, which lets the buttermilk pass through. The butter is then formed into a mass, as described before.

It is an acknowledged fact, that such are the niceties of the dairy that great experience alone can insure a produce of superior quality, and this expericnec would be more readily acquired if the circumstances were accurately obscrved and noted. Wic wonld recommend to those who have extensive dairies, to mark by the thermometer the temperature of the milk and cream in the different stages of the process; occasionally to test the acidity of the buttcrmilk by means of alkalis; and to note any peculiarity in the atmosphere by an clectrometer. A few observations, carefully noted, repeated, and compared, would throw 
more light on the true eanses whieh favor or oppose the production of good butter, than all the guesses that have hitherto been made.

The quality of the butter depends materially on the nature of the pasture. The best is made from eows fed in rich natural incadows. Certain plants, which grow in poor and marshy soils, give a disugreeable taste to the butter. The eommon notion that the yellow Hower called the buttercup gives eolor and flavor to butter is a mistake; eows never crop the flower if they can avoid it, and the whole plant is acrid and unpalatable. When cows are fed with eut grass in the stable, the butter is inferior, except in the case of some artificial grasses, such as lucern. Turnips and other roots given to cows in winter communicate more or less of a bad taste to butter, which is eorrected in soine degrec by means of a sinall quantity of water and saltpetre added to the milk; and also, it is said, by giving salt to the cows with their food. But there is no butter made in winter equal to that which is made when the cows are fed entirely with good meadow hay, especially of the seeond crop, ealled after-math hay, whieh eontains few seed stalks.

The yellow color of May butter is frequently imitated artifieially, by mixing some ground anatto root, or the juice of carrots, with the cream. This is easily deteeted by the taste of the butter, which is not improved by it, and lias not the peeuliar flavor of fine grass butter ; but in other respects it is a barnless addition. Some eows give a inuch yellower eream than others, espeeially the Alderney eows; and the butter made from it is of a peculiarly fine flavor. When a eow lias lately ealved, the milk is also inueh yellower, but this soon goes off, if it be not the natural color; and the butter made by mixing this with other milk, although of a deeper color, is not improved by it.

According to the accounts of the produce of butter from different countries and various brecels of cows, we may state that, on an average, four gallons of milk produee sixteen ounces of butter; and to make the feeding of eows for the dairy a profitable eniployment, a good eow slionld produee six pounds of butter per week in summer, and lialf that quantity in winter, allowing from six weeks to two months for her being dry before ealving; that is one lundred and twenty pounds in twenty weeks after ealving, and eighty pounds in the remainder of the time till she goes dry-in all, about two hundred pounds in the year. If she produees more, she may be eonsidered as a superior eow ; if less, she is below par.

The quality of the butter produeed in England and in IIolland is eonsidered the best. A eonsiderable quantity of Duteh butter is exported, but all that is produced in England is consumed at home, in addition to large quantities imported from Ireland and the continent of Enrope. The quantity imported has been for some time progressively increasing.

Premilum Butter-Making,-The following, read at the last meeting of the American Institute Farmers' Club, details the practiee of one of the best butter-1nakers in the State of New York, Mr. Jesse Carpenter, of Elnira, in that state. It was communicated by Mr. H. E. Lowman. We invite the speeial attention of all our dairy readers to the views here propounded, as they come from a source entitling them to 
the highest confidence. Mr. Carpenter has long been known in the butter making region, and in the market, as one of the most intelligent and suecessful dairymen and farmers in the eounty, and as a manufacturer of the veritable "Orange county butter:"

"The basis for a good and profitable butter-dairy is, a stock fulfilling as nearly as practieable all those eonstitutional and struetural eonditions which eombine in the animal high milking qualities, with good size, robust healtll, and longevity. The next step is a prompt and thorough praetice of the best inethod of treatment of the same by which the largest yield of the best quality of milk is secured. The next and best step in the achievement of a first-elass dairy of butter is the application to its manufacture of an intimate and eritieal knowledge of the true proeess-from the expressing of the milk to the final touch the butter reeeives preparatory to the transit of the paekage to market.

"How to take the first step? i. e., lay in the stock, or near it, Mr. Carpenter thinks ean be known much more satisfactorily by referenee to and study of popular authorities on the subject-writers who have made the rearing of stoek with that view a speciality, and yet it is practieal, common sense, and close and accurate observation which must be the main dependence at last. The next branch of inquiry, which is none the less important, is not so easily pursued to satisfactory results by an appeal to the same sources of information. Long and elose experience has eonfirmed Mr. Carpenter in the accuracy of the following system or mode of treatment: the best summer food for the dairy stock, that which yields the largest quantity and best quality of milk, is a mixture of the finer grasses, such as red and white elover, timothy, and blue grass, all of which thrive well in desirable eombination in the pasture fields of the Chemung Valley. All coarse, rank, ar. strongly-flarored weeds, of whatever deseription, must be banished from the feeling range of the dairy stock, otherwise butter of the finest quality eannot be inade. Neitlrer should they be fed during the milling senson on any description of roots or coarse pungent vegetables, sncl as eabhage, if the butter is to be packed in firkins or any other vessel with the purpose of keeping.

"Even pumpkins are not desirable, though they may be used without material detriment. In the spring the season roots are most eommonly used and advised. A small allowanee of grain is mueh more beneficial. It aceomplishes just what is needed, witlont eontributing to undesirable results. It gives additional strength of muscle-the inain thing desired-while, if judieiously given, it does not materially increase the deposit of fat. It also increases the quantity, and improves the quality of the milk, while roots and vegetables increase the quantity, but ratleer deteriorate the quality.

"During the milking season the cows must be moved from the pasture-ficld witl great caution to prevent overlueat of the system. That eannot take plaec in any degree without the milk being untavorably affeeted in a corresponding ratio. And when they are in the heat of the sexual or eopulating tever, tlre milk shonld not be used in the dairy, or with that froon which butter for paeking is to be made. For at such periods nature has provided for a medical interruption of the secretion 
of the animal, and the milk is greatly reduced in quantity, and in like measure improved in quality. Indeed the abnormal heat produced in the udder is of itself sufficient eause for rejecting the milk for buttermaking. In the fall, where the grass begins to fail, and loses its nutritive or milk-prodneing elements, there is nothing that ean eqnal cornstalks as a substitute. The corn should be sown for the purpose.

"During the winter months the stock should be stabled of otherwise sheltered from the severities of the weather for the night, and while they feed. And the care, and amount and kind of food must be so appointed that they rather improve in condition and vigor than otherwise; at least they must not be allowed to run down to poor flesh and weakness; for then no amount of attention and good nursing through the summer will restore them to full milking eapacitics. The loss is irreparable for the season.

"A very thorongh and practical understanding of the next and last

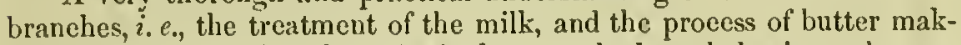
ing, is much more difficult to obtain, beeause the knowledge is much more diffieult to impart. With all the rules that may be given, therc must be superadded, as conditions for their sucecssful applieation, the neessity for close and eritical obscrvation. For there are eonstantly arising eireumstances to modify the most of such which may be laid down in a general system.

"For depositing the milk when strained, the tin pail of the capacity of about twelve quarts is preferable to any other kind of vessel. It is suffieicntly large to fulfill all the requirements in that particular; while its supcriority over the shallow pan-which is considerably used -is too palpable to adnit of doubt. The following propositions in point, are sustained by facts, the applieation or pertinency of which, all who have ever made butter, or who have been in a dairy with their eyes open to the cvery day phenomena therein, will readily apprehend, viz.: that milk, in order to realize from it the largest quantity and best quality of butter, must stand in an atmosphere of a given temperature a speeific lengtl of tine, in all cases, in order to perfect it for the cliurn; that natural or artificial causes, either aecelcrating or retarding the processes of eliange in its elements fron that fixed standard, have their like certain results of detcrioration, both in the quality and the quantity of the butter produced; that a given quantity of milk, with the greatest surface exposure to the action of the atmosphere, in a given teinperature, will change more rapidly than a like quantity in a like temperature, with a less surface cxposurc. The facts in proof, it need scarcely be intimated, condemn the use of the shallow pan.

"Every dairy-woman has observed the effeets of a close, muggy and humid atmosphere-sueh as often precedes rain-storms in the suminerupon the milk; also, of a thunder-storm, also of only partly filling a vessel. In all cases named, the change in the milk is much more rapid than when the temperature of the atmosphere is cren, and the equilibrim of its vital elements more perfectly sustained; and then in pails filled to their capacity. In all these instanees too, the milk must be churned sooner. But there is no method that will prevent a loss of product in quantity and quality. 
"It is diffieult to reach fully the truth of the first proposition. But we ean approximate to it, and then adapt our practice as nearly to sueh standard or rule as it is possible to do. The temperature of the room where the milk is set must never exeed $65^{\circ} \mathrm{F}$, and must be as stearly and even as possible. The atmosplicre of the same must be kept perfectly pure; for any odor peculiar to the decomposition of vegetable or organic substances mingling therewith, will inevitably leave its taint upon the milk and its produet.

When the casein is precipitated or the milk coagulated, it is ready to ehurn. It must not stand until the seeond ehange takes plaee in the lacteal or the sugar of milk; that is, until the laetic acid beeomes butyrie acid, the latter stage of which may be known from the diseolored spots of mould gathered on the surface of the eream. The thick milk slould always be emptied with the eream into the ehurn. There are two important reasons in support of this metlod. First, the eream never all rises to the surface, and there must always remain with the eoagulated part quite a fraetion of the fatty matter, which is lost if not churned. Second, there is a virtue in the casein and lactic aeid which is essential in the process of churning to import to the product the element of preservation. It is a faet which should be known by all dairy-men and dealers, that the product of eream exclusively, however skillfully manipulated, will not, if packed for keeping, preserre for any length of time the finer qualities of good butter:

"The milk in the ehurn, when fit for churning, should indicate $64^{\circ}$ Fah., and should be agitated with a movement of the dash at not less than fifty strokes to the minute. Less motion will fail to divide properly the butter from the milk. When done, the butter should be taken from the churn and thrown into a tub or a small churn partly filled with water $42^{\circ}$ to $44^{\circ}$ Falh, and the buttermilk foreed out with a small dash. It should then be put into trays and washed until the water used ccases to be the least diseolored with buttermilk. It is then ready for salting, which should be done and the trays immediately earried to the cellar. The proper amount is $1 \frac{1}{4}$ oz. to the pound of butter after working-i.e., the butter should retain that amount when ready for packing. When it has stood three or four hours after the first salting, it should be stirred with a ladle and left in the torm of a honey-comb, in order to give it the greatest possible surfaee exposure to the air, whieh gives color and fixes the high tlavor.

"Sutter when well manufactured, while standing preparatory to packing, is composed of granulated partieles, between which are myriads of infinitesimal eells filled with brine, which is its life. At this period it should be touehed with a light hand, as too much and too eareless working will destroy its granular and cellular character, and reduee the whole to a compact and lifeless inass, with an immediate loss of flavor, and a eertain and reliable prospeet, if packed, of a rapid change of its charaeter from indifferently good to miserably poor butter. It slould never be worked in the tray while in a dry state, or all the ill results just alluded to will be realized. As a general rulc, after the butter has stood in the trays tweuty-four hours, and has been worked three or four times, as directed, it is ready for packing. After the firkin is filled, it should stand 
a short time, and then should be eovered with a elean piece of muslin, and the whole eovered with brine.

"It will not be out of plaee for the writer to state from his own knowledge, and upon his own responsibility, a few facts in eonnection with the above, referring solely to Mr. Carpenter's suecess as a dairyman. For the last twenty years, besides fattening the ealves to the eustomary age of four weeks, he has averaged a fraction over two firkins to the cow per year. II has had butter stand in packages in his eellar for one year and a lialf, and open them with a flavor so fresh and sweet that the very best and most eritieal judges and buycrs were deceived one year in its age-noue even suspecting it to be the product of a former year. He never has, during that period, failed to reach in New-York market the highest figure representing the maxinum market for Orange county bntter; and latterly, he has very often overreached the very highest market half a eent to two and a half eents per lb."-Tribune.

Mfessrs. Charles R. IIuntington \& $\mathrm{C}_{0}$, produce commission merehants in New-York, give the following directions to their eonsignors for the shipment of bitter to them, \&e.

"The best butter is obtained at a temperature of fifty-one degrees, and the greatest quantity at a temperature of forty-six degrees, Fahr. Diring the process of ehurning the agitation will inerease the lieat to about five degrees more than it was when the cream was put into the churn. The operation of ehurning, whether it be of erean alone, or eream and milk, is performed in the same manner. The milk requires more time than eream to complete the process, from two to three hours being considered neessary ; while cream alone may be effectually ehurned in an hour and a halt. The operation should be slow in warm weather, for if done too hastily the butter will be soft and white. If the eream is at too high a temperatıre, the ehurn slıould be cooled with eold spring water, to reduce it to the proper degree of heat. In winter, again, the operation of elurning should be done as quickly as possible, the action being regular, and the churn should be warmed to raise the temperature of the milk or eream. The air which is generated in the ehurn should be allowed to eseape, or it will impede the progress by the froth which
it ereates.

"After the elurning is performed, the butter should be washed in cold spring water, with a little salt in it, two or three times, to extraet all the milk which may be lodging about the mass. The less milk which is in the bntter, its quality is proportionably improved; after all the milk has been carefully extraeted, the butter should be mixed with the finest ground rock-salt, in the proportion of five ounees to seren pounds. The butter and salt shonld be well mixed together with the hand or ladle. This superior salt for dairy purposes may always be obtained at the very lowest prices by addressing your orders to us.

"Firkins made of oak, with walnut hoops, to eontain one hundred pounds of butter, net, are generally the most desirable; but many prefer Welsh tubs, either ash or oak. Packages should be made smooth, and should be got into market as bright and eleanly as possible. The demand is about equally divided between tubs and firkins.

"Butter, as it is recoived by morchants from small dairies, should be 
packed down soljcl, while it is fresh and swcet; aud as there is usually a diversity of color, great pains should he taken to keep each shadc by itself. To accomplish this, several paekages may be filling at the same time, each one receiving its respective shade; so that when thcy are full, it will hore uniform in color upon the trier. A elean linen cloth, thoroughly saturated with strong brine, should be laid on the top, and a slight layer of moistened salt upon it. This not only preserves the butter, but gives to it a neat appearance.

"Nothing pleases commission merehants more than to receive a strictly fine dairy of bntter-sweet, yellow, rosy to the smell, and delieious to the taste. It sclls readily at a satisfactory price, and cvery body is pleased, from prodncer to consumer. Common and inferior butter sticks, notwithstanding its greasiness, at every stage, cansing lissatisfaction and trouble from begiuning to end. It is either over-salted, under-salted, colorless, milky, sticky, strong, rank or rancid, or all thcse combinedat any rate, it is not what it should be, and is eonsequently unsalable."

Cheese and Cheese llakillg.--In the making of clicese there are eertain general principles which are essential, but slight variation in the process produces eheeses of very different qualitics; and although the inost important circumstance is the nature of the pasture on which the cows are fed, yet much depends on the mode in which the different stages of the fabrication are managed; and henee the great supcriority of the cheeses of particular distriets or dairics over those of others, without any apparent difference in the pasture. In those countries where the cows are ehiefly kept tied up in stalls, and are fed with a variety of natural and artifieial grasses, roots, and vegetables, superior cheese is often made.

The first proeess in making elieese is to separate the curd from the whey, which may be done by allowing the milk to become sour; but tho chcese is inferior in quality, and it is diffieult to stop the acid fermentation and prevent its running into the putrefactive. Various substances added to inilk will soon separate the cnrd from the whey. All acids curdle milk. Muriatic acid is used with suceess for this purpose in Holland. Some regetables contain aeids which readily eoagulate milk, such as the juicc of the fig-tree, and the flowers of the Galinm verum, or ycllow lady's bed-straw, henee called cheese-rennet. Where better rennet eannot be procured, they may be substitnted for the best eurdler of milk, which is the gastric juice of the stomach of a sucking calf. 'This juice rapidly coagulates the milk as the ealf sneks; and the only difficnlty is in collceting and keeping it from pntrefaction, which begins from the instant the stomach is taken from the calf. The preparation of the rennet, as it is called, is a most iuportant part of the process of eheesemaking. The following may be considered as the simplest, and perhaps the hest. $\Delta$ s soon as a sueking ealf is killed, the stomach should be taken out, and if the ealf has sueked lately, it is all the hetter. The outer skin should be well scraped, and all fat and useless membranes earefully removed. It is only the inner coat which mnst be preserved. The coagulated milk should be taken out and examined; and any substanee besides enrd found in it shonld be carefully removed. The serum left in it should be prossed out with a eloth. It should then be replaced 
in the stomach with a large quantity of the best salt. Some add a little alum and sal prunella; others put various herbs and spiees, with a view of giving the eheese a peeuliar flavor; but the plain simple salting is suffieient. The skins or vells, as they are ealled, are then put into a parl, and eovered with a saturated solution of salt, in which they are soaked for some hours; but there must be no more liquor than will well moisten the vells. They are afterward hung up to dry, a pieee of flat wood being put erosswise into eael to stretel them out. They should be perfertly dried and look like parehment. In this state they may be kept in a dry plaee for any lengtl of time, and are always ready for use. In some plaees, at the time of making eheese, a pieee of vell is ent off, and soaked for some hours in water or whey, and the whole is added to the warın milk. In other plaees, pieees of vell are put into a linen bag, and soaked in warm water, until the water has aequired suftieient strength, which is proved by trying a portion of it in warm milk. The method employed in Switzerland is as follows:- a dry vell is taken and examined; it is seraped with a knife, and where any veins or pieees of tough membrane appear, they are removed. The whole surface is examined and washed earefully, if any dust or dirt lias adliered to it; but otherwise it is only wiped with a elotl. A handful of salt is then put into it, and the edges of the vell are folded over and seeured with a wooden skewer stuek through it. In this state it forms a ball of about three inehes diameter, and is laid to soak twenty-four loours in a dish eontaining about a quart of elear whey, which has been boiled, and all the enrd taken out. The next day the vell is well squeezed, and put into fresh whey; the first infusion being put into a pioper vessel, the seeond is afterward mixed with it, and bottled for use. Ilalf a pint of this liquor, of a proper strength, is suffieient to eurdle forty gallons of milk. Experienee alone enables the dairyman to judge of the strength of his rennet; for this purpose he takes in a flat ladle some milk which has been heated to about ninety-five degrees of Fahr., and adds a sioall measure of rennet. By the rapidity witlı whieh it eurdles, and by the form of the flakes produced, he knows its exaet strength, and puts inore or less into the ealdron in whiel the milk is heated for eurdling.

There are different kinds of eheese, aeeording to the mode of preparing it: soft and rich eheeses are not intended to be kept long; hard and dry eheeses are adapted to be kept and stored for provisions. Of the first kind are all eream eheeses, and those soft eheeses, ealled Bath eheeses and Yorkshire eheeses, which are sold as soon as made, and if kept too long beeome soft and putrid. Stilton and Gruyère eheeses are intermediate ; Parmesan, Duteh, Cheshire, Gloneestershire, and similar cheeses, are intender for longer keeping. The poorer the eheese is, the longer it will keep; and all eheese that is well eleared from whey, and suffieiently salted, will keep for years. The small Duteh cheeses, ealled Edam eheeses, are admirably adapted for keeping, and form an important article in the victualing of ships.

The Gruyère and Parmesan eheeses only differ in the nature of the milk, and in the degree of heat given to the eurd in different parts of the proeess. Gruyere eheese is entirely made from new milk, and Parmesan from skimined milk. In the first nothing is added to give flavor: 
in the latter saffron gives both color and flavor; the process in both is exactly similar. A large caldron, in the shape of a bell, capable of holding from 60 to 120 gallons of nilk, liangs from an iron crane over a hearth where a wood fire is made. The milk, having been strained, is put into this caldron, and heated to nearly blood-heat $\left(95^{\circ}\right.$ to $\left.100^{\circ}\right)$. It is then turned off the fire, and some rennet, prepared as stated aborc, is intimately mixed with the warm onilk by stirring it with the hand, in which is held a flat wooden skimming-disl, which is turned round in the milk while the hand and arm stir it. A cloth is then laid over the caldron, and in half an hour, more or less, the congulum is formed. This is asccrtaincd by pressing the skimming-dish on the surface, when the whey will appear on the part pressed. If it is longer than an hour in coagulating, the milk has been too cool, or the rennet not strong enough. When the curd is properly formed, it is cut horizontally in thin slices by the same skimming-ladle. Earelr slice, as it is taken off, is poured along the side of the caldron which is nearest to the opcrator; by this means every portion of the curd rises strecessively to the surfacc, and is sliced thin. The whole is then well stirred, and the caldron is replaced over the fire. A long staff, with a small knob of hard wood at the end, and which has smaller cross pieces or sticks passed throngh holes in it at right angles to each other near the end, is now useel to stir and break the curd, and the heat is raised to about $135^{\circ}$, which is as hot as the arm can well bear, even when used to it. 'The caldron is again swrung off the fire, and the curd is stirred with the staff, which is noved round with a regular rotatory motion, the knob running along the angle formed with the side by the botton of the caldron, which is in the form of a bowl. After stirring in this manner nearly an lour, the curd is found divided into small dics about the size of a pea, which feel elastic and rather tongh under the fiuger. Lxperience alone can teach the exact feel they should have. The whey, of which a portion is remored occasionally, now floats at top, and the curct is collected in the botton by giving a very lapid rotatory motion to the contents of the caldron by means of the staff. A cloth is now introduced into the bottom, and ail the curd collected orer it; it is raised by the four corvers, and laid on an instrument like a small ladder, which is placed across the mouth of the caldron. The whey runs ont through the cloth, which is a conmon chcese-cloth, woven with wide interstices; and tho curd in the cloth is placed in a shape or hoop, made of a slip of wood, four inches and a half widc, the two ends of which lie over cach other, so that the diameter can be increased or lessened. A cord fixed to one end of the hoop is passed with a loop over hooks on the outer surfacc of the other cnd, and prevents the ring from opening more than is required. The curd is pressed into this ring with the hands, and the ends of the clotll arc folded over it. A round board, two inches thick, and strengthened by cross pieces nailed on it, is placed over the curd, and the press let down upon it.

During the next six or eight weeks the cheeses are turned and wiped every day, and a small quantity of finc salt is sifted on the surface, and rubbed in with the hand until they will take no more. The cheese-room is always very cool, and little light is adınitted.

A free circulation of 
air is esscntial. The cheeses are in perfection in about six months, and will keep two years. A quantity of elastic fluid is disengaged in tho ripening, and forms those round ejes which are a peculiar feature in these checses. The snaller and rounder the eyes, the better the elieese is reckoned. They should contain a clear salt liquor, which is called the tears; when these dry up, the clieese loses its flavor.

In Cheshire the making of eheese is carried on in great perfection, and the greatest pains are taken to extract every particle of whey. For this purpose, the curd is repeatedly broken and mixed, the cheeses are much pressed, and plaeed in wooden boxes, which have holes bored into them. Through these holes sharp skewers are stuck into the cheese in every direction, so that no particle of whey ean renain in the curd. The clastie matter formed also escapes through these ehannels, and the whole eheesc is a solid mass without holes, whieh in this ehecse would be looked upon as a great defect. The salt is intimately mixed with the curd, and not merely rubbed on the outside. Tlis cheeks internal fermentation, and prevents the formation of elastic matter.

Gloneester and Somersetshire eheeses are similarly made, with this differenee, that the eurd is not so often broken or the cheese skewered; and a portion of the eream is generally abstraeted to make butter. After the curd has been separated from the whey, and is broken finc, warm water is poured over it, for the purpose of washing out any remaining whey, or perlaaps to dissolve any portion of butter which may have separated before the rennet had congulated the milk.

Stilton cheese is made by adding the eream of the preceding evening's milk to the morning's milking. The cream should be intimately ineorporatcd with the new milk; great attention should be paid to the tempernture of both, as much of the quality of the chcese depends on this part of the process. 'To make this cheese in perfeetion, as unuch depends on the management of the cheese after it is inade as on the richness of the milk. Each dairy-woman has some peculiar method which she considers the best; and it is certain that there is the grcatest differcnee between eheescs made in eontiguous dairies. The rennet should be very pure and sweet. When the milk is coagulated, the whole eurd is taken ont, drained on a sieve, and very moderately pressed. It is then put into a shape in the form of a cylinder, eiglat or nine inches in diameter, the axis of which is longer than the diameter of the base. When it is suffieiently firm, a cloth or tape is wound round it to prevent its breaking, and it is set out on a shelf. It is occasionally powdered with flour, and plunged into hot watcr. This hardens the outcr eoat, and favors the internal fernentation which ripens it. Stilton eheese is generally preferred when a green mould appears in its texturc. To accelerate this, pieces of a monldy cheese are sometimes inserted into holes inadc for the purpose by the seoop, called a taster, and wine or alc is pourcd over for the same purpose; but the best cheeses do not require this, and are in perfcetion when the inside becomes soft like butter, without any appearance of nouldincss. In making very rich eheeses, the whey must be allowed to run off slowly, beeause, if it were forced rapidly, it iniglit carry off a great portion of the fat of the cheesc. This happens more or less in overy mode of making cheese. To collect 
this superabundant butter, the whey is set in shallow pans, as is done with milk when butter is made; and an inferior kind of butter called whey-butter is made from the ereau of fat skiummed off.

Cheeses are frequently colored-a practiee which probably arose from the notion of making the eheese look richer; but now it deceives no one. Yet if some ehecses were not colored they would not be so marketable, owing to the assoeiation that subsists between the color and the quality of the eheese. The substancc used for coloring is most eommonly anatto. It is ground fine on a stone, and mixed with the milk at the time the rennet is put in. The juice of the orange carrot, and the flower of marigold, are also used for this purpose. Cheddar, a eheese made in Somersetshire, which is highly prized, Stilton, Derby, and some other eheeses, are never eolored; Cheshire slightly; but Gloueester and North Wiltshire decply. Foreign eheeses are only colored very slightly, if at all. 'The Duteh cheeses arc made in a very similar manner' to the Gloueester cheeses, but the milk is generally curdled by means of muriatic aeid, or spirits of salt; and great care is taken to prevent fermentation, and to extraet the whole of the whey. For this purpose the curd is repeatedly broken and pressed; and before it is made up into the round shape in which it is usually sold, the broken curd is well soaked in a strong solution of common salt in water. This diffuses the salt thronghout the whole mass, and effectnally checks fermentation. When the elieeses are finally pressed, all the whey which nay remain is washed out with the brine; salt is likewise rubbed over the ontside, and they are set to dry on shelves in a cool plaee. The flavor of the cheese is perhaps impaired by the stoppage of the fermentation; but it never heaves, and it acquires the valuable quality of keeping well even in warm climates. From the place where this cheese is coinmonly made, it is known by the name of Edam cheese. $\Lambda$ finer cheese is made at Gouda and other places, by imitating the process in making Gruyère cheese; but this eheese is always full of sinall eavities, and will not keep so long as the Edam. The eheese most commonly met with in Holland is a large lind of skim-milk eheese, which is made very like Cheshire eheese. It grows hard and dry, and has not much flavor. To supply this defect, cummin seeds are mixed with the curd, which those who are accustomed to it consider a great improvement. On the whole, it is a better elieese thin our Suffolk skim-milk cheese, and forms an important part of the provisions usually stored for a Dutch family. In France, the Roquefort eheese is compared to our Stilton, but is much inferior, although a good chcese. The little cheeses made from cream and folded in paper, ealled Neufchâtel cheeses, are imported from Franee as a delicacy. 'They can be easily imitated, being nothing more than cream thiekened by heat, and pressed in a small mould. They undergo a rapid change, first becoming sour and then mellow, in whieh state they must be eaten.

The green Swiss cheese, commonly callch Schabzieger, is produced in the Canton of Glarus. The curd is pressed in boxes, with holes to let the whey run out; and when a considerable quantity has been collected, and putrefaction begins, it is worked into a paste with a large proportion of a ccrtain dried herb reduced to powder. This herb, called in 
the country dialect Zieger kraut (curd herb), is the Melilotus officinalis, which is very common in most countrics, and has a peculiar aromatic flavor in the mountains of Switzerland. The paste thus produced is pressed into moulds of the shape of a common flowcr-pot, and the putrefaction being stopped by the aromatic herb, it drics into a solid mass, which kecps unchanged for any length of time. When used, it is rasped or scraped, and the powder, inixed with fresh buttcr, is spread upon bread. It is either much relished or much disliked, like all those substances which have a peculiar taste and smell.

When a chcese which has bcen much salted and kept very dry is washed several times in soft watcr, and then laid in a cloth moistencd with wine or vinegar, it gradually loses its saltness, and from being hard and dry, becomes soft and inellow, providerl it be a rich chcese. This simple method of improving checse is worth knowing. It is generally practiced in Switzerland, where cheeses are kept stored for many ycar's, and if they were not very salt and dry they would soon be the prey of worms and mites. A diy Stilton cheese may thus be nuch improved.

The Lactometer, - This instrument is designed to test the cream qualitics of milk. Pour the milk into the tubes, and the cream, when risen, will show how rich the milk is. The depth of erean will be shown by the figures on the tubcs. By the lactoneter the difference in the quality of the milk of differcnt cows may be readily ascertained.

The qualities of ercam vary much in the differeut brecds, depending on the modes of management, as wcll as the food. Thus, in some experiments made, it required twclve quarts from a short-horn cow to produce one pound of butter-somcthing like a day's supply of milk; whilc nine and a half quarts of an Ayrshire cow's would give the same quantity; but it is often very variable in the samc animal at different periods, and different animals of the same breed will produce very different results both in cream and buttcr.

Profits of the Cow, -Our first illustration is from Mr. Thomas Tufts, of Le Roy, Genesec county, N. Y. On the 1st of November, 1838, he says: "I have a cow six years old last spring. On the 29th of May she brought a calf; and on the 27 th of June I took from her at three inilkings, inorning, noon, and uight, of one day, thirty-one and a half quarts of good rich measured milk, which was not more than an averagc for the whole month. The last wcek in July, I found that her milk failed a little, and being some trouble, I stopped milking her three times a a day. On the last day of July, at two milkings, twenty-four quarts; on the last day of August, twenty-one and a half quarts; on the last day of Scptember, eighteen quarts; and on the 31 st day of October, I took from her fifteen quarts. She had no feed but that of common pasture, in which, however, was plenty of good water and shadc, from the first of June till the last of Scptember, and lodged at night in the barn-yard. On the 1st of October she was turned into a mowing-ficld; and during the last week in that month was fed onee a day on bay, and twicc a day on ruta-baga tops."

In July, 1845, a writer in the Agriculturist says: "I have a cow that ealved about the middlc of January, and is now eleven ycars old. The ealf I fattened in the following manncr: the first week I gave it one 
teat; the seeond week, two; afterward, three. The ealf was sold for nearly six dollars; and in the mean tinne, milk to the amount of \$1.75. Simee that time I have realized for milk sold between fourteen and fifteen dollars; making the profit of the eow thus far, the present year, nearly twenty-three dollars, besides what I nsed in my own family, consisting of eight persons." Dr. Woodward informed the editor of the same journal that he had a cow whieh, in the year 1844, gave one thousand and fifty gallons of milk, which, at four eents a quart, would anonnt to one hundred and sixty-eight dollars. He also had, on the Hospital Farm, Worcester, Massachnsetts, several other eows nearly as good. And Willian Cushman, of New Braintree, in that state, says, July 14th, 1845: "I have a cow whieh has given, for ten days in June, from fifty-four and a half to sixty-three pounds of milk per day." She was one-fourth of the Durham breed.

Peter II. Sehenek, formerly a merehant of New York, but having a eountry residenee in Dutehess eounty, in Oetober, 1843, says : " $\mathrm{My}$ eow Emma was nine year's old last spring; and till the summer of 1842 I never kept her milk separate from that of three other eows I have. Then I made the experiment for one week, during whieh she gave eighteen quarts per day, and the milk macke fifteen pounds of butter." On the 21 st of the following May - that is, 1843-he renewed the experiment, and for the three weeks ensuing she made sixty-five and a half pounds of bntter. On the 35 th of Jnne, that same year, the milk that eame from her was ehurned by itself, and the butter weighed three pounds eight ounees. The next day her butter weighed three pounds four ounces.

In 1843, a gentleman in the neighborhood of Troy, New York, says: "George Vail, Esq., of that eity, was the owner of two eows only, one a full-blooded Durham, seven or eight year's old, and the other four years old, seven-eighths Dnrham. He kept an aeeurate aceount of their milk and butter for thirty days. The result was as follows: one hundred and eight pounds of butter, besides supplying a fanily of five persons with new milk and eream for ordinary family use, and nine quarts of new milk daily for a ealf. The average weight of milk per day, from the oldest eow, was sixty-eight pounds, and from the other, sixty pounds, during the thirty days. ln the same year, Judge Walbridge, of Ithaea, in that state, had a eow that gave in the seven days ending June $24 \mathrm{thl}$, three hundred and ninety-five pounds ten ounees of milk, being an arerage of fifty-six and a half pounds per day, or twenty-eight and a half quarts per day. She had made two pounds one ounee per day, when two quarts of the milk were taken for family use. And the Rev. William Wisner, in the same neighborhood, had a eow, that in May of the same year made forty-seven pounds of butter, and supplied two families with new uilk daily, during the time."

Among the more recent statisties of the dairy, the two following are selected. The first is from the Exeter News-Letter, whieh says: "Mr. Abraham Rowe, of Kensington, N. H., has a cow lie raised from an Eastern breed, six years old, from which was made, between the 20th of May and the 20th of October, 1849, one hundred and fifty-six pounds of butter, averaging over one pound a day from pasture feed 
only. It being his only eow, furnished his family with their eream and milk besides." The seeond is from the Furmer and Mechanic, which says: "The best eow now in the United States is probably owned near Geneva, N. Y., which through the month of June, 1849, gave forty-two quarts of milk per day; and for five days she gave forty-five quarts per day. The eow is half Durham and half of the native breed."

The Somerset Messenger. New Jersey, contains a eommunieation from J. W. Van Arsdale, stating the profits of a half-blooded Durham eow owned by him, for ten months from the 1st of April, 1849, to the 1st of February following. He sold in that time to the retailer 3,022 quarts, at 2 and $2 \frac{1}{2}$ eents a quart, amounting to $\$ 70.51$, besides reserving a suffieient quantity for the use of his tamily of eleven persons, and about two messes of milk twiee a week for baking purposes. The 3,022 quarts were sold by the retailer at double the priee he gave for it, that is, for \$141.02. He ealenlates that this amount of milk would have made 302 pounds of butter, whieh, at 20 eents a pound, amounts to $\$ 60.40$. The eow has not had extraordinary eare-having had two quarts of oat and eorn meal per day during the dronght last snmmer, and three quarts last spring before grass and this winter. And a farmer in Essex eounty, in that state, realized during twelve months previons to February 1st, 1850 , a net profit of $\$ 456.09$ from three ordinary eows-animals of the common breed of the eountry-that in most other hands would not probably mueh more than have paid for their keeping. As it is, they have supplied the family with all their milk and erean, paid for their keeping in full, as appears by a minute daily account, and yielded the above-named profit of $\$ 456.09$.

It is unnecessary to gather up more similar eases. Onr agrieultural journals are filled with them. Now, suppose a farmer resolve that he wonld keep no eow that did not hold out a good milker nine months in the year, and that did not give sixteen quarts of milk per day for two months after ealving, twelve quarts per day for the next four months, six quarts per day for the next three months, and two quarts per day for the following inontl, sueh a eow would yicld per annmm 3,000 quarts of milk, whieh, at four eents a quart, would be $\$ 120$. Considering the eases above given, is not this feasible? With sneh eows, what if it does eost five or ten dollars a year more to keep them than is ordinarily expended for the purpose? May not sueh eows be raised? No matter if they do eost fifty or sixty dollars eaeh ; they soon pay for themselves.

If the varions modes of obtaining this objeet were resorted to at onee throughout the eountry, there would be a vast improvement in a very short time. No young animal of promising appeararree for milk would go to the buteher. More eare would be taken of young stoek. More young stoek would be retained to insure a better seleetion for milk eows. Farmers would think more of the advantages of employing the in. proved breed. Heifers would be milked with great eare and very thoroughly, to get them in the habit of holding out longer as milkers. If they onee dry early, no eare and keeping will afterward eorreet the fault. Heifers with the first ealf, especially, should be well fed, and with some additional eare, the last three months they are in milk, to make them hold out. 
It is supposed that a milk eow of medium quality, in this part of the country, will give twelve quarts of milk for two months after ealving, seven quarts per day on grass for the next four .nonths, four quarts per day for the following two months, and perhaps two quarts per day for one month more; making altogether 1,500 quarts in the year.*

TIIE SPAYING OF COWS.†-A land-owner in the United States, Mr. Winn, seems to have had the first practice in spaying eows. The objeet of the operation was to maintain in the eow, without interruption, a supply of the same quantity of milk that she gave at the time of spaying. Notwithstanding the favorable results that Mr. Winn elaimed to have obtained, the operation remained almost unknown in Franee until a veterinary surgeon of Lausanne (a Swiss), M. Levrat, made known the experiments practiced by him, and their effeets. The treatise of M. Levrat ends with the following eonelusions:

"The effect of spaying seems to me to be, to cause a more abundant and constant secretion of milk, which possesses also superior qualities, whenee the following advantages result to the proprictor:

"1. An inerease of one third in the quantity of milk. milk.

"2. The ecrtainty of having almost eonstantly the same quantity of

"3. Exemption from aceidents whieh may happen during the period of heat, when the eows mount each other, or are covered by too large
bulls.

"4. Exemption from the risk of aecidents which sometimes aceompany or follow gestation and ealving.

"5. Ease in fatting eows, when their milk begins to dry up.

" 6 . In fine, spaying is the only means of preventing onerous expenses, oceasioned by eows beeoming 'taurelières,' which is so frequently the ease in some countries, that it is raie to see eows kept more than two or three years withont getting in this state; as, for example, in the environs of Lausanue and Lavaux, where they are obliged for this reason to change all their eows every two or three years, which is quite ruin-
ous."

M. Levrat eonfirmed, after a year's observations, this fact, that the quantity of milk was constantly kept the same after the time of spaying.

M. Régère, veterinary surgeon at Bordeaux, inserted in the Recueil de Médécine Vétérinaire, a series of faets upon the spaying of eows, that had been aeted upon by various proprietors.

It appears from these faets, which he reeounts with inany details, and whose authentieity is fixed, that the spayed eows have given, without average of what they gave during the preeding years. "After the researches that I have made sinee I eommeneed all these experiments, to the present time," says M. Régère, "this ealeulation is very exact, and if the eows eontinue to give nilk during their whole life, in like manner,

* "Farmer's Kvening Day-Book."

$\uparrow$ Statement of M. P. A. Morin, Veterinary Surgeon at tho Royal Depot at Langonnet. Translated for the Working Farmer, from "La Normandie Agricole Journa
"Agriculture Pratique." 
the operation of spaying will furnish ineontestable advantages, particularly in large eities, and their vicinity, where fodder is very dear, and where milk always sells well."

$\Lambda$ remark made by MN. Levret and Régère is, that some cows, although they have been spayed, have had their heat, notwithstanding the removal of their ovarium, and the incapacity for their reproduction. These animals present, at the time of their lieat, this differenee from what we remark during the same period in cows not spayed, that their nilk does not undergo any alteration in either quantity or quality.

We may add, that the school of $\Lambda$ lfort has, recently, practieed this operation upon different cows, and that all the results obtained have reached the point we have above stated.

Leaving this, we arrive at the facts determined by M. Morin :

"Young cows ought to receive that nourishment which favor's the seeretion of milk, and which in eonsequence renders active their lactiferous vesscls. The eow is not usnally in full production until after the third or fourth calf; she continues to give the sane retnrn up to the seventh or eighth; from this tine lactation diminishes after each new calving. On the other hand, from the inoment that the cow has received the bull, and gradnally as gestation advanees, the quantity of milk progressively diminishes in most breeds, until three or four months before healthy parturition, the secretion of milk is almost notling. It is to guard against this loss, and other inconvenienees, that we lay down what we have obtained after some years' experienee in spaying the cow, and the happy results that we meet with dicily.

"Of the spaying of the Cow, and the Adrantages of this operation,The operation of spaying in the cow is productive of great advantages.

"1. The cow spayed a short time after calving, that is to say, thirty or forty days afterward, and at the time when she gives the largest quantity of milk, continues to give the like quantity, if not during her whole lifetime, at least during many years, and at the time when the milk begins to dry up the animal fattens. We are able to add, moreover, at this day, certain facts, the result of many years' experiment, that the milk of the spayed cow, although as abundant, and sometimes more so, than before the operation, is of a superior quality to that from a cow not spayed; that it is uniform in its character, that it is richer, eonscquently more buttery, and that the butter is always of a golden color.

"We believe that we onght to remark in passing, that if we feed the spayed cow too abundantly, lactation diminishes, and that the beast promptly fattens. It is therefore important that the feeding should not be more than sufficient to enable us to obtain the desired result.

"2. The spayed cow fattens more casily; its flesh, age considered, is better than that of the ox; it is more tender and more juicy.

"Indeed, no one is ignorant of the fact that all domestic animals, females as well as males, deprived of their procreative organs, fatten morc quickly than those which retain them; that the flesh of the spayed temales is more tender and more delicate than that of males. The same phenomena take place among spayed cows that occur among other females that have submitted to this operation; so, besides the 
advantage of furnishing a long-eontinued supply, before commencing a course of fattening, of abundant milk, and butter of a superior quality, the cow fattens easily and completely, and a certain bencfit follows this course.

" 3 . In spaying decrepit eows, that is to say, of the age of from six to seven years, puny, small ones; those which, though fine in appearance, bear badly; those which are subject to miscarriage; those which frequently cxperienee diffieult ealving, or delivery; those diffieult to keep; and finally, all those that are taurelieres-that is to say, eonstantly in heat-we have, in addition to an abundant production of milk and butter, and a faeility of fattening, the advantage of preventing a degeneration of the speeies, and, moreover, of avoiding a crowd of aceidents or maladies whieh frequently take place during or after gestation, and of diminishing those which happen during the period of heat, sueh as that of heavy cows mounting others, or being juinped upon by too lieavy bulls.

"Except under peculiar eircumstanees, we should take care in spaying the cow that its teats liave aequired their complete development, and that the milk has the proper qualities. The most suitable time is after the thind or fourth ealving.

"Many soeicties of agrieulture, impressed with the important results that this operation effects, fix yearly at their agricultural meetings premiums for the encomragenent of the spaying of old eows. We doubt not that other societies-who have not yet adopted this plan, not being convinced of its importance, when they are-will imitate their example. By this means they bestow upon the country a new souree of produets.

"We have been engaged for four ycars in researches upon this valuable discovery; we believe that it is incumbent upon us to state the results that we have obtaincd up to the present time. In the number of twenty-seven cows, aged from six to fifteen years, that we have aetually spayed, we have had the following results: 1. Inerease of milk in cows of six years; 2 . Constant produetion in those that have passed that age; 3 . Milk riclier than that of the cow not spayed, consequently more buttery, and the butter both of a uniformly golden color, and having an aroma and taste far superior to that of a eow that lias not undergone this opcration.

"Early in July, 1842, we obtaincd, as a subject of experiment, a cow from Brittany, of the small kind, twclve years old, calved about two months before, and which gave, when we obtained her, about six quarts of milk daily. The next day after we performed the operation of spaying-indeed the first cight days after that-the secrction of milk sensibly diminished, in consequence of the light diet on whieh she liad been put; but, on the ninth day, the time at which the cure was complete and the eow put on her ordinary food, the mills promptly returned, as to its former quantity, and she at the sane time assumed a plumpness that she had not had previously. Customarily bringing together the yield of three days for butfer-making, being eighteen guarts, it produced constantly two kilograms of butter of the best quality. Froin the inonth of December to the following March, the quantity of milk diminished about one-third, and the butter proportionally, the cow during that time 
having been put on dry fodder. But so soon as we were able to turn her into pasture-about the beginning of April-the milk, after eight day's of this new food, resumed its former eourse, and the aninal continued daily to furnish the same relative amounts of milk and butter as before.

"Three eows, two of whieh were fourteen years old, and the other fifteen, have dried up two years after the operation, and at the same time promptly fattened, without inerease or change of foud.

"One eow, eight years old, plentifully supplied with trefoil and eabbage, gave, a short time after the operation, a quantity of milk nearly double that which she gave before, although she was kept on the same kind of food. She has during a year eontinued to furnish the same amount, and has, in addition, fattened so rapidly, that the owner has been obliged, seeing her fatness, to sell her to the buteher, although she was still very good for milk.

"Another fiet, no less worthy of remark, we must not pass over in silenee; and which goes to prove the superior and unehanging quality of the milk of a spayed eow. It is, that a proprietor having spayed a eow five year's old, reeently ealved, with the speeial intentiou of ficeding with ber milk a newly-born infant, the infant, on arriving at the age of six months, of a robust constitution, refused its pap when it was onee aeeidentally prepared with milk different from that of the spayed eow.

"The other eows whieh had been spayed eontinued to give entire satisfaetion to their owners, as well in respeet to the quantity and quality of the milk, as also by their good eondition.

"Six eows manifested, slıortly after the operation, and on divers oeeasions, the desire for eopulation; but we have not remarked this peenliarity exeept among the younger ones. In other respeets, as my colleagues MM. Levrat and Régère have stated, the milk has not indieated the least alteration in quantity or quality.

"Indeed, the happy results that are daily attained from this important diseovery are so conelusive, and so well known at this time in our part of the eountry, that, as we write, mauy proprietors bring us eonstantly good mileh eows, sinee we have ealled upon them to do so, for us to praetiee the operation of spaying upon them. Every owner of eattle is aware that, from the time that the eow has reecived a bull, and in proportion as gestation adranees, the milk ehanges and diminishes progressively, until at last, two or three months before a healthy parturition, the animal gives very little or no milk, whenee ensues eonsiderable loss; while at the same tine, after the eows are subjeeted to the bull, the milk and butter are, for fifty days at least, of a bad quality, and improper to be exposed for sale; but, in addition to this, breeding eows are generally subjeeted to sueh loss in winter, and their keepers find thernselves during a great part of the year entirely deprived of milk and butter, and at a time, too, when they most need them.

"By eausing the cows to undergo this operation, as we have inentioned in the preeeding remarks, the owner will never fail of having milk and butter of exeellent quality ; will fatten his animals easily when they dry up, and also will improve the race, an anxiety for whieb is pereeived in many provinees of Franee. 
"In general, the means employcd by farmcrs to obtain the best possible price for old cows, beyond being iseful, or, to usc a commercial term, not mcrehantable, is to bring them to the bull, intending that gestation shall give them more snitable plumpness, so that they may be sold on more advantageous terins to thc butcher; but does this state of fictitions embonpoint or fatness, render the flesh of these beasts better? Assuredly not. It is merely bloated, flabby flesh, livid, and which easily taints. Broth made from it is not rich, is withont flavor, and withont an agreeable smell; the lean and fat are in a mcasure infiltrated with watcr, and are consequently of bad quality and very difficult sale. These causes onght then to determine farmers to adopt the advice we give: they, as well as the butcher and the consumer, will derive very great advantage from it.

"As our method of operating may be slightly diffcrent from that pointed out by our collcague, M. Levrat, we will describe that which we practicc.

"Having covered the eyes of the cow to be operated upon, we place ber against a wall provided with five rings firmly fastened, and placed as follows: the first corresponds to the top of the withers; the second to the lower anterior part of the breast; the third is placed a little distance from the angle of the shoulder; the fourth is opposite to the anterior and superior part of the lower region, and the fifth, which is behind, answers to the under part of the buttocks. We place a strong assistaut between the wall and the head of the animal, who firmly liolds the left horn in his left hand, and with his right, the muzzle, which he elevates a little. This done, we pass through and fasten the end of a long and strong plaited cord in the ring which corresponds to the lower part of the breast; we bring the free cud of the cord along the left flank, and pass it through the ring which is bclow and in front of the withers; we bring it down along the breast behind the shoulders and the angle of the fore-leg to pass it throngl the third ring; from there, we pass it through the ring which is at the top of the back; then it must be passed around against the outer angle of the left hip, and we fasten it, after having drawn it tightly to the postcrior ring by a simple bow-knot.

"The cow being firmly fixcd to the wall, we place a cord, fastencd by a slip-noose around its hocks, to kccp them together in such manner that the animal cannot kick the operator; the free end of the cord and the tail are lield by an assistant. The cow, thus secured, cannot, during the opcration, move forward, nor lie down, and the veterinary surgeon has all the ease desirable, and is protected from accident.

"M. Levrat advises that an assistant should hold a plank or bar of wood obliquely under the teats and before its limbs to ward off the kicks; but this method is not always without danger, both to the operator and the animal, because, at the commencement, that is, when the surgeon makes the incision tlurough the hide and the muscles, the cow makes such sudden movements, and tries so frequently to strike with its left hind foot, that it may liappen that upon cvery movement, the plank or the bar may be struck against the operator's legs. On the other hand, although the defense may be firmly held by the assistant, yet it 
may happen that, in spite of his exertions, he somctimes may be thrown against the operator by the movements sle may attempt, and there may be an uncontrollable displacement of the plank or bar; and then it may happen that shc becomes wounded, and at thc same tine prevents the opcration, while, by the mode we point out, there is no fear of accident, either to the operator or the beast. In casc of thc want of a wall provided with rings, we may use a strong palisadc, a solid fence, or two trees a suitable distance apart, across which we fix two strong bars of wood, separatcd from each other according to the size of the cow.

"There is another incaus of confining them that we have cmployed for some time past, where the cows were very strong and irritable, more simple than the preceding, lcss fatigning for the animal, lcss troublesomc to the opcrator, and which answers perfectly. It consists: First. In leaving the cow almost free, covering her eycs, holding her head by two strong assistants, onc of whom scizes the nose with his hand and strongly pinches the nostrils, whencrer the animal makes any violent movements during the operation. Second. To causc another assistant to hold the two hind legs, kcpt together by means of a cord passed above and beneath the hocks; this assistant also holds the tail and pulls it, whenever the animal secks to change its place.

"The cow being conveniently disposed, and the instruments and appliances, such as curved scissors, upon a table, a convex-edged bistoury, a straight one, and one buttoned at the point, a suture necdle filled with double thread of desircd length, pledgets of lint of appropriatc size and length, a mass of tow (in pledgets) being collected in a shallow basket, held by an intelligent assistant, wc place ourselvcs oppositc to the left flank, onr back turncd a little toward the head of the animal; we cut off the bair which covers the hide in the middlc of the flanks, at an equal distance betwcen the back and the hip, for the space of thirteen or fourteen centimetres in circumferenec; this done, wc take the convex bistoury, and placc it opened between our tceth, the cdgc out, the joint to the left; then, with both hands, we seize the hide in the middle of the flank and form of it a wrinkle of the requisite elcvation, and running length wise of the body. We then dircet an assistant to seize with his right hand the right side of this wrinklc; wc then takc the bistomry that we held in our tceth, and we cut the wrinkle at onc stroke through the middlc; the wrinkle having bcen suffered to go down, a scparation of the hide is presented of sufficient length to enablc us to introduce the hand; therenpon we separate the edges of the hide with the thumb and forefinger of the lcft hand, and in like manncr, wc cut through the abdominal muscles, the iliax (slightly obliquely) and the lumbar (across) for the distance of a ccntimetre from the lower extremity of the incision made in the hide; this donc, armed with the straight bistoury, we make a puncture of the peritoneum at the upper extremity of the wound ; we then introduce the buttoned bistoury, and move it obliquely from above to the low cr part up to the termination of the incision made in the abdominal inuscles. The flank bcing opened, we introduce the right hand into the abdomen and dircet it along the right side of the cavity of the pelvis, bchind the cul de saurumen (paunch) and un- 
derneath the rectum, where we find the cornes de Cuterus (matrix); after we have ascertained the position of these viscera, we searel for the ovaries (organs of reproduction), which are at thc extremity of the cornes, and when we have found them, we seize them between the thumb and forefinger, detach them completely from the ligaments that keep them in their place, pull lightly, separating the cord, and the vcssels (uterine or fallopian tube) at thcir place of union with the ovarium, by means of the nail of the thumb of the forefinger, which presents itself at the point of touch; in fact, wc break the cord and bring away the ovarium. We then introduce again the hand into the abdominal cavity, and we procced in the same inanner to extract the other ovaria. This operation terminated, we, by the assistance of the needle, place a suture of three or four double threads waxed at an equal distance, and at two ccntimetres or a little less, from the lips of the wound; passing it through the divided tissues, we move from the left hand witl the piece of thread; having reached that point, we fasten with a double knot, we place the seam in the intervals of the thread from the right, and as we approach the lips of the wound, we fasten by a simple knot, with a bow, bcing careful not to close too tightly the loser part of the seam, so that the suppuration which may be established in the wound, may be able to cseape. This operation effected, we cover up the wound with a pledgct of lint kept in its place by three or four threads passed through the stitches, and all is completed, and the cow is then led back to the stable.

"It happens, sometines, that in cutting the muscles, of which we have beforc spoken, we eut onc or two of the arteries, which blecd so much that there is necessity for a ligature before opening the peritoneal sac, because, if this precaution be omitted, blood will escape into the abdomen, and may occasion the inost serious consequences.

"Care After the Operntioll.-The regimen we prescribc during the first eight days following the operation, is a light dict, and a sootling lukewarn draught; if the weatler should be cold, we cover the cow with a woolen covering. We must prevent the animal from licking the wound and fiom rubbing it against other bodies. The third day after the opcration, we bathe morning and evening about the wound, with water of unallows, lukewarm, and in defanlt of this, we anoint it with a salve of hogs' lard, and wc administer an ennollient glyster during three or four days.

"Eight days after the operation we take away the bandage, the lint, the fastenings and the thrcads; the wound is at that timc completely cicatrized, as we have observed that a rcunion takes place almost always by the first intention, as we lave only observed suppuration in three cows, and then it was very slight. In this case we must use a slight pressurc above the part where the suppuration is established, so as to cause the pus to leave it, and if it continues more than five or six days, we inust supply emollients by alcoholized water, or chloridized, especially if it be in sumincr. Wc then bring the cow gladually back to her ordinary nourishment.

"We have remarked in some cows a swelling of the body a short time after bcing spayed, a state that we have attributed to the intro- 
duetion of cold air into the abdomen during the operation; but this derangement has generally eensed within twenty-four hours. If the contrary should occur, we administer one or two sudorific drauglits; such as wine, warm eider, or half a glass of brandy, im a quart of warm water; treatment which suffiees in a short time to re-establish a healthy state of the belly, the animal at the same time being protected by two coverings of wool.

"The operation which we have been describing, ought to be performed as we have said before, thirty to forty days after calving, upon a cow which has had her third or fourth calf, so that we may have a greater abundance of milk. The only precaution to be observed before the operation, is, that on the preceding evening we should not give so copious a meal as nsual, and to operate in the morning before the animal has fed, so that the operator shall not find any obstacle from the primary digestive organs, especially the pauneh, which, during its state of ordinary fullness, might prevent operating with facility.

"Conclusion, - From what has preeeded, it is fixed and irrefutable1. That spaying induees permaneney of milk, increase of quantity, and improvement of quality ; richer, more buttery, superior color, finer taste and flavor. 2. The most suitable age is six years, and after the third or fourth calf. 3. The spayed cow fattens more easily, and furnishes beef of a better quality. 4. Cows that are bad breeders may be kept as good milkers, and the quality of good cattle kept up."

DISEASES AVI RENEDIES. - Thlis is perhaps the most unsatisfactory division on which a writer on eattle can pretend to write. There are more cattle destroyed than cured by the strange quackery and drenching pursued by their over-officious owners; and to write any thing to encourage a system so ruinous is to perpetuate the evil. The first thing a dairyman or grazier does is to get a long list of "reccipts" inserted in a book, classified or not, but all under the numes of ecrtain diseases. A cow falls ill. She has the yellows, or the staggers, or the worms, not because there are any clear and decided symptoms, but because the owner fancies it is so, and his specific is administered. He watehes intently, and no good effeet is produced; he runs for another medicine prescribed by another liand; the one opposing, and perhaps counteracting the other. One neighbor looks in, and perhaps another; each advises a medicine, as empirical as that of the owner, and all must be given, unti! the symptoms increase and get so bad that the village quack is sent for, who is more elever than the rest, becanse he has a larger range of "reeeipts," and he adds his quota of drugs, until the beast dies, poisoned by medieine!

Now, so long as unprofessional men will continue to preseribe and treat obstinate and complieated complaints; and so long as the public press will pander to the receipt-mania, there is no hope of any anendment. Certainly we sliall lend no aid to the system.

But there are some simple and inanifest ailinents where the farmer may hiniself administer simple medicines; and there are some eases of emergency, too, when it may be necessary to do something, tull scientific aid ean be obtained. To these cases we will allude. We will take the complaints in the order of their frequency. 
Felon.-This is a complaint common to all kinds of cattle. It proceeds from cold and exposure, and is accompanied by low fever. 'The beast is more or less off his food. IIis coat is staring, his eye dull, his nose diy, his back sorp, he will flinch from the touch, and his teeth feel loose. It is an attack of felon. IIe requires ronsing by cordials. Let lim be housed and given a drink: one ounce of turmeric, one ounce of fenngrcek, one ounce of liquorice, one ounce of aniseed powder, in a quart of alc; and he will generally recover; if not, repeat the dose. A very common and a very safe process is also to divide the nerve of the under side of the tail. This relieves the back, and is thus performed: Fecl for a soft place in the under side of the tail. The knobs are the joints, the soft place is the bone. Cut the skin across at the soft part, and it will bleed for cight or ten minutes. Tie up the tail with a piece of linen cloth, and great relief will be afforded. This is not mentioned in any work we ever met with, but we have scen its efficacy in hundreds of instances.

Hovell, Blowil, or "Over Full."-Sometimes a change of food, or a feed of wet clover or potatocs, grcedily eaten, will induce fermentation in the stomach instead of digestion. The sides will be blown up, until the stomach presses on the skin, with a foree which renders it hard to the fingers. l'or this the probang is by far the best remedy. Introduce this into the stomach by the throat, and the foul air will immediately escape. This instrument is not always at hand, and the beast will lie down, and the disease may continue until the walls of the stomach are ruptured. In these cases an ounce of ammonia will often give relicf. $\Lambda$ pint of vincgar we have kuown to effect it; but the safest remedy is a pint of linseed oil. It lubricatcs the mouth of the stomach, and assists the air to escape by both the orifices, otherwisc closed up. Gentle exereise will be useful; but all violence, and, above all, such horrid drenches as tar and salt, with the idea of making them eject their saliva, can only do harm. It is sometimes necessary to ent into the stomach, an operation a veterinary surgeon alone can perform.

Choking.- $\Lambda$ beast will often get a turnip or potato fast in its throat, which will resist all efforts to get it either up or down; and, what is worsc, when once this bas taken place, the beast will always after be liable to the same accident. The mouth should first be carefully examined, to see that the turnip cannot be cxtracted with the hand; if it can be, this is the best mode by far for effecting its extraction. 'If not, the probang, invented by Dr. Munro, is absolutely neccssary. Let a little sweet oil be first given to the animal, and then let the probang be carefilly and cantiously put down, the cup end downward; if the turnip offers much resistance it must again be withdrawn, and by this its position may be changed. Generally it will go down, witlt a very slight effort, and sometimes it may be got np by rumning the thumbs up each side of the neck, and gently pressilig with the hand.

Calvillg.-This, though not a disease, is rightly classed amongst them, because it is strictly a subject of medical and surgical treatment; and, though a natural operation, is always accompanicd by more or less danger. In old cows, or cows after their first and second calves, if the right presentation takes place, the animal will generally calve without 
meehanical hclp. It often happens, that eows which calve unobserved, do the best, and we know a very careful and sueeessful grazier who makes a point of never interfering in ordinary eascs. There is ecrtainly more danger from premature assistanee than from delay. Usually the waters are the first symptoms of decided labor. A thin filmy bag first breaks, and after this the eow will sometimes eat, and seen comfortable for an hour. The second is larger and thicker, and envclops the feet of the calf. When the feet arc therc, or one begins to protrude, the other may be sought for, and when both are brought forward, mechanieal assistance may safely be rendercd, if the head is found between and above then. A cow-tie may be strung round each foot, and certainty of the head being between them is a signal for a slow and gentle pull, avoiding any thing like force, and the pulling being downward towards the ndder. But above all things, give time. The museles relax and give way for the calf, if proper time is allowed. When ealving is over, follow the direetions formcrly given in l'cgard to the management of the mother and producc, - the latter should suek, and the mother liek the ealf.

False Presentations will sometimes take plaee; - a single foot, or the head, or the hind legs. In either of these cases, the opcrator must wait for one of the throes being over, and then gently put back the ealf, and introduee his hand, whieh has been previously oiled, and bring forward the legs which are wanting. If this cannot easily be donc, a veterinary surgeon will be neccssary. When the hind legs alone are presented, it is only neeessary to proeeed in the usual way. In eases of difficulty, of malformation in the mother, of water in the head, or monstrosity in the ealf, it is always best to call in a veterinary surgcon.

Some parties have a praetice of giving cvery cow a ealving drink. We uniformly prefer, as we said, nature's incdicinc, the licking of the calf, to any and all others which can be given. If it has been a long and protracted labor, a drink of warm grucl will be useful. If the cow refuses to liek the calf, which heifers of their first ealves will sometimes do, it is seldom neccssary to do more than run the hand over the newly dropped calf, and then pass it aeross the month and lips of the inother.

Abortion is a labit with some individual cows, and is often the result of the presence of blood, or bad smclls, arising from putrid matter deeaying near the cow-houses or yards; and once introduccd into a cowhouse, it often so affeets the imaginations of the rest, as to bccome epidemic. Let the cow and the remains of the calf be instantly removed from the rest, and kept alone and quict. Chloride of lime shonld be plentifully sprinkled near the stall wliere she was, and the whole of the herd should have their noses besmeared with tar.

Retention of the Placenta, or failing to cleanse, after calving, sometines oeeurs; and it requires grcat care to prevent its retention, when the expulsion does not take place in a few liours after calving. It indieates weakness, and want of tone in the uterus. $\Lambda$ mild stimulant niay bc given-nothing better than an infusion of chanomile flowers, say two handfuls in a quart of water, added to a quart of good boiled ale, and if necessary, an injeetion of soap-suds, to kecp open the bowels and prevent inflammatory action. If it resists all efforts, and begins to putrefy, it will be necessary to consult a veterinary surgeon. 
Red Water.-This is a complaint which frequently attacks cows in summer; and, on some pastures, it is a regular oecurrence. If taken in an early stage, a dose of eight ounees of Epsom salts, dissolved in a pint of water, will almost invariably set the beast right. If not at hand, a pound of eommon salt may be given, and the dose repeated, in ease of need.

Quarter Felon.-Inflammatory fever, or quarter-ill, is one of the most obstinate diseases with which eattle can be afflicted; and, though odd instances of a cure have been reported, they are extremely few, unless the disease has been attacked in a very early stage. It is also highly contagious, and will sometimes go through an entire herd of ealves before they are a year old, for it seldom occurs after that period. The ealf gets off its food, and beeomes lame and stiff in one foot. The foot may be examined, and no eause of lameness diseovered, but soon the discase has become general; air bubbles are formed between the skin and muscles, and there is a cracking sensation to the hand on passing it over the skin, especially in the legs. Inflammatory fever is disorganizing the body.

Preventives, as the seton in the dewlap, bleeding, in autumn, doses of dyer's madder, ete., are favorite remedies. The seton can do no harm, -it may be tried; but no specifie, either remedy or prevention, has yet been discovercd.

Foul in the Foot.-This is a tiresome, worrying disease, to which large heary milk cows are specially subject; and is to the cow what foot-rot is to the sheep. There is inflammatory aetion between the elaws; it begins to diseharge fetid matter, and is a source of prin and irritation, whicl often dries up the milk, and is often a painful and annoying coinplaint to eure. Let the foot first be well eleaned and fomented with warm water, and all loose flesh be cut or elipped off. The foot may then be poulticed for one night with flaxseed-meal poultice, and then again fomented and anointed with tar; and, if it should smell very offensively, a little charcoal, or a few drops of clıloride of lime may be added to the water. Next day the inflammation will be relieved and bronght out cxternally by the tar, and the foot may be then dressed with the butter of antimony (clyloride of antimony) night and morning, and the tar applied afterward. The foot should be confined in a boot or stocking, and kept free from dirt. A little salts or linseed-oil should be given to keep the bowels in a state of gentle aetivity.

llilk Fever.-This is a common complaint with eows which are deep milkers, at least in summer. Prevention is all the farmer has to do with, for the cure, if any, must be left in the hands of the veterinary surgeon. $\mathrm{He}$ inust, if he see the udder distended, milk the eow before calving regularly three times a day; she must be kept as cool and quiet as possible, and have mashes of bran only, for a few days after ealving. This is eooling and somewhat laxative, and if the ulder should bc liard, which it should not be after this treatment, let it be rubbed with marslı inallow oint nent. A gentle dose of purgative medieine may be given if the cow is it. very ligh eondition, and slie should be driven a few miles every day before ealving. With these preeautions there is little danger, at least of its being fatal. 
The Yellows, or Jaundice.-This is easily distinguishable. White cattle are pecularly subject to it, and it makes its firt appearanee by a yellowness of the eyes and under the anus; the bowels become costive, the teetl loose, the appetite gone, and rapid wcakness sets in. Give $4 \mathrm{oz}$. eornmon salt, half oz. Barbadoes aloes, $1 \mathrm{dr}$. gingcr, 1 quart home-brewed ale, made into gruel.

Loss of Cud,-All ruminating animals are sometimes subject to this. The stomael, with a sort of eonvulsive action, throws the half masticated food back into the mouth to be rechewed, and soinetimes this healthy contractile tone of the stomaeh is lost. Give $-6 \mathrm{dr}$. Barbadoes aloes, $6 \mathrm{oz}$. common salt, $3 \mathrm{dr}$. ginger, $1 \mathrm{oz}$. alspice, in a quart of gruel.

Inflammation.- This is a disease known by eoldness of the horns and extrenities, generally aecompanied by much acnte and eonstant pain. All home attempts to eure this disorder will be impotent; a veterinary surgeon should be at onee eonsulted. The same may be said of staggers, strangury, and a variety of aente disorders.

Pleuro-Pnenmonia is only mentioned to say that nothing like a specifie has, so far, been diseovered. 'The fearful medicine of a gill of spirits of turpentine and a gill of spirits of sweet nitre seems to be the most successful but desperate remedy. If the animal is fat, there is scareely a ehance of recovery. If the animal is lean, remedial measures may be tried, but they are inore likely to fail than be snccessful.

The Epidenic, or Sore Dlouth and Feet, - for so a disease which affeets the inonth with blisters and the feet with pain and inflanmation, is best known, has lost mneh of the virulenee it possessed from 1839 to 1844 , but still is sometimes tronblesome. A dose of Glanber or Epsom salts, in the first stage, with shelter and bran mashes, will generally prevent evil eonsequenees. Should the foot break out, the same treatment will be useful that we advised in the foul of the foot.

Diseases of Calves.- If well managed, ealves are subjeet to few diseases; and if starved, negleeted, or ill inanaged, they will be seareely kept alive by medieine. The nost fatal disease is the scour or diarrhea. As it usually proeeeds from some foreign, often aerid matter, in the bowels, a tablespoonful of snlphur in the milk will generally remove it in due time. If it should continue after this, give a tcaspoonful of laudanum and a tablespoonful of tineture of rhubarb. We onee had a ealf nearly dead of diarrhoa; medieine scemed to have no impression upon the obstinate attack. It was dying. We gave it a bottle of port wine, expecting it wonld be dead in the morning. In the morning, however, it was well and crying for its breakfast. A pint of good old port will often work wonders when all other remedies have failed, both in man and beast.

Costiveness is sometimcs a disease in ealves, as well as the opposite extreme. Here it is undesirable to give medieine, unless it be very severe. A handful of onions, boiled with an onnee of fat baeon, is by far the best remedy, and it never does injury, but is nutritions to the animal even if well.

Gripes is a complaint to whieh young ealves are subjeet, which have had sour milk given to them; and there is often aente pain exhibited, kicking of the belly with the hind legs, pawing, ete. A eure is gener- 
ally effeeted, in a remarkably short time, by a eupful of peppermint water and a teaspoonful of laudanum.

The great secret of kecping all animals is to tend them earefully and keep them well. Let the land said to be subject to disease be well drained and better farmed; let the bad herbage and cold beds of the cattle be cured and they will be healthicr and thrive better. It is better always to pay the eake-erusher or the miller, than to pay the veterinary surgeon, however skillful he may be.

In conelusion, treat the eow well, and she will be grateful. Let all your procedings be dictated by liumanity and kindness, and a more patient and grateful servant you eannot have. 

T H E

\section{DOMESTIC SHEEP:} THEIR

BREEDS, M A N A GMENT,

AND

D I S E A S E S. 


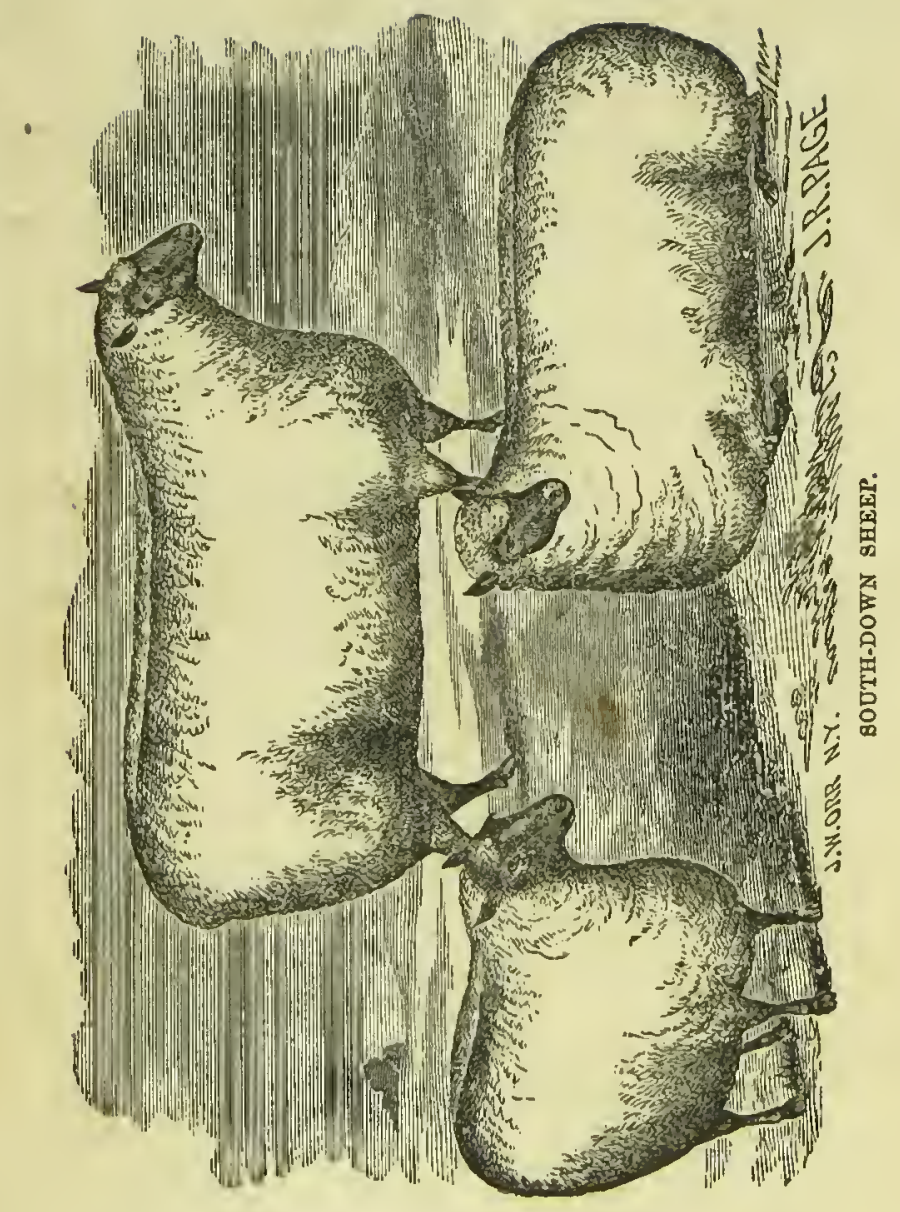




\section{THE DONESTIC SHEEP:}

\section{THEIR BREEDS, MINAGEMENT, ETC.}

BREEDS OF SIIEEP IN TIIE UNITED STATES.-The principal brceds of shcep in the United States are the Native sheep, the Spanish and Saxon Merinos, the New Leicester, or Bakewell, the South-Down, the Cotswold, the Cheviot and the Lincoln.

The Nalive Shecp are the variously mixed descendants of those originally introduced by the first colonists. They yiclded wool suited only to the coarsest fabrics. They were slow in arriving at maturity, compared with the improved English breerls; and the weight of fleee, and quality and quantity of mutton, were inferior to the improved English breeds. They have now, lowever, bccome nearly extinct, by crosses with forcign breeds of later introduetion.

American Hcrinos,-Of these there are three elasscs, or varictics. The first isalarge, short-legged and hardy sheep, the wool ranging from mcdium to finc, and without hair when well fed-rarely exhibiting gum externally - their wool thick, and comparatively long on the back and bclly, and whiter than that of the French sheep called the Rambouillets, and thcir skin has the rich rosc-color of the latter. The second general class of American Mcrinos are smaller than the preceding-less hardy-wool as a general thing fincr-covcred witl a black pitchy gum on its extremities-fleece about one-fonrtl ligliter than in class first. The third class, which have been bred mostly Sonth, are still sinaller and less hardyand carry still fincr and ligliter fleeces. The Heecc is destitnte of extcrnal ginn. Thic sheep and wool bear a close resemblance to the Saxon; and if not actually mixed with that blood, they have been formed into a similar variety, by a similar conrse of brceding. Class first arc a larger and stronger sheep than those originally imported from Spain, carry much heavier flceces, and in well selected flocks, or individuals, the fleece is of a deciledly better quality.*

The Merino Heece is in Spain sorted into four parcels. The following cut, whilc it contains the portrait of a Merino ewc, points ont the parts whence the different wools are generally procured. The division cannot always be accuratc, and especially in shecp of an inferior quality, but it is more to be depended upon in the Merino shecp wherever fonnd, for the flcece is more equally good, and the quantity of really bad wool is very sinall.

Both Lasteyric and Livingston agrec in this division. The refina, or the pick-lock wool begins at the withers, and extends along the back to the setting on of the tail. It reaches only a little way down at the quarters, but, dipping down at the tlanks, takes in all the superior part of the ehest, and the middle of the side of the neck to the angle of the lower jaw. The fina, a vahuable wool, but not so decply serrated, or

* Randall's "Sleep Husbandry." 


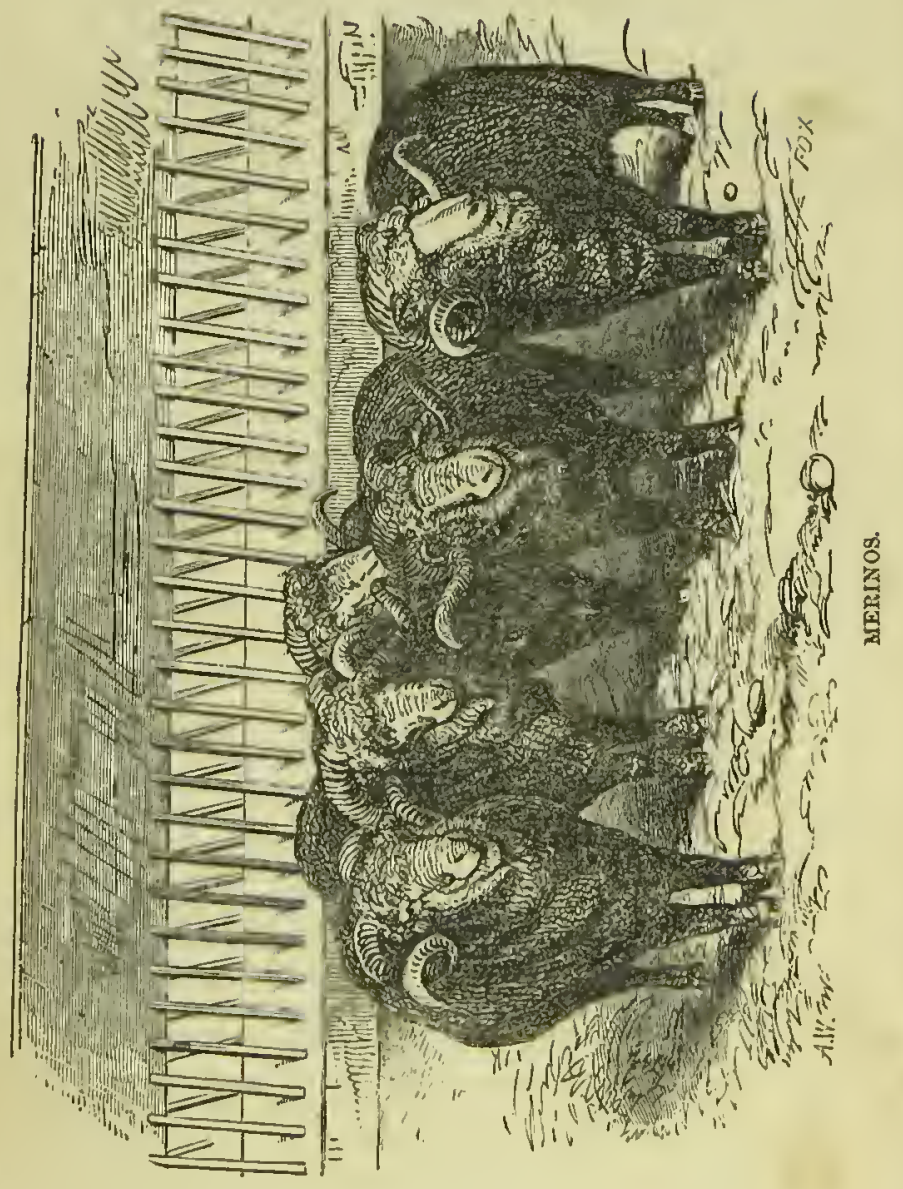


possessing so many enrres as the refine, oceupies the belly, and the quarters and thighs, down to the stifle joint. The terceira, or wool of the third quality, is found on the head, the throat, the lower part of the neek, and the shoulders, terminating at the elbow: the wool yielded by the legs, and reaching from the stifle to a little below the liock, forins a part of the same division. A small quantity of very inferior wool is procured from the tuft that grows on the forchead and eheeks-from the tail, and from the legs below the hock.

The Spanish wool eontinues to be highly valued by the manufacturer; and the Spanish breed of sheep will be regarded with interest as the inprover of the best old short-wooled ones, and the parent of a new race, spreading through every quarter of the world, and with which, so far as the fleece is concerned, none of the old breeds can be for a moment compared.

Saxoll Mlerinos.-This breed is the result of transferring, nearly a century ago, the best Spanish sheep into Saxony, where they appeared to thrive better than in their native region.

Very great cure is taken by the Saxon sheep-master in the selection of the lanıbs which are destined to be saved in order to keep up the flock: there is no part of the globe in which such unremitting attention is paid to the floek. Mr. Charles Iloward, in a letter with which he farored the author, says, that "when the lambs are weaned, each in his turn is plaeed upon a table, that his wool and form may be minutely obserred." The finest are selected for breeding, and reeeive a first mark. When they are one year old, and prior to shearing them, another close examination of those previously marked takes place: those in which no defect ean be found, reeeive a second mark, and the rest are condemned. A few months after, they in like manner reeeive a third mark, when the slightest blemislı eauses a rejection of the animal.

The utmost care is also taken in the honsing and feeding of their flocks, evidently aiming rather at a fine staple of wool, than a hardy race of sheep. Mr. Carr, a large shecp-owner in Germany thus deseribes their management and its effeets :

They are always boused at night, even in sunmer, exeept in the very finest weather, when they are sometimes folded in the distant fallows, but never taken to pasture until the dew is off the grass. In the winter they are kept within doors altogether, and are fed with a small quantity of sound hay, and every variety of straw, whieh has not suffered from - wet, and which is varied at each feed ; they piek it over earefully, eating the finer parts, and any grain that may liave been left by the threshers. Abundanee of good water to drink, and roek-salt in their cribs, arc indispensables. . . . . They cannot thrive in a damp climate, and it is quite neeessary that they shonld have a wide range of dry and hilly pasture of short and not over-nutritions herbage. If allowed to feed on swampy or marslyy ground, even onee or twiee in autumn, they are sure to dic of liver complaint in the following spring. If they are permitted to eat wet grass, or exposed frequently to rain, they disappear by luund reds with eonsumption. In these eountries it is found the higher bred the sheep is, especially the Eseurial, the more tender.

The Ameriean Saxon sheep have been so largely intermixed with 
American Merinos, and other imported and native breeds, as to render it diffienlt to find one of pure breed; yet eareful breeders have generally such good stoeks, that it is questioned by good authority, whether the admixture, after all, has deteriorated the Saxons among us, - that crossing with Merinos has a tendency to inereased hardiness in the animal, withont in any important degree affecting the fineness of the wool staple.

The wool of the American Saxons is mueh finer than that of American Merinos, their fleeces average from two or two and a quarter to three pounds. They are relatively tender, requiring more protection and eare than any other imported sheep. They are not as long-lived as the Merinos, do not fatten as well, nor eonsume as mueh food. Their lambs are less vigorous and require more care to rear them.

The New Leicester, or Bakewell.-It was about the middle of the last century that $\mathrm{Mr}$. Bakewell, of Dishley in Leieestershire, first applied himself to the improvement of the old Lcicesters. This old breed had nany good points, yet it had its defects, and these of no trifling character; it was large, heavy, and coarse-grained, the mutton having little flavor, and no delicacy ; it was long in the eareass, flat-sided, large-boned, and elumsy; the ewes weighed eighteen or twenty pounds the quarter, the wethers from twenty to thirty pounds. The wool measured from ten to fifteen inches in the length of the staple, and was variable as to quality, but generally coarse. These sheep were slow feeders, and returned little profit.

Such was the stock common to Leicestershire and the adjacent eounties, on which Mr. Bakewell began his course of experiments; in the prosecution of which he violated all the old axioms of his day, and proceeded upon prineiples totally at varianee with those by which the breeders had previously regulated their practice. They aimed at size, irrespective of symmetry and aptitude to fatten; and at heavy fleees, considering weight of wool as of primary importance. Mr. Bakewell on the contrary regarded symmetry and aptitude to fatten as first-rate qualities; he found these to be inherent in small, not in large heavyboned sheep, which latter consumed an extravagant abundanee of food without returning an adequate profit; whereas the sunaller shecp he found to increase more rapidly in weight, proportionately, even upon a less consumption of diet. His experience had also taught lim another point, viz., that sheep carrying a heavy fleee had al ways less aptitude to fatten, and were far slower in ripening, than those whose fleee was moderate; and he considered symmetry and early ripening to be of more importance than the loss of a few pounds in the fleeee. In short, he eonsidered that the value of the careass was the first olject to be attended to in breeding of sheep; and he looked upon the fleee as of seeondary importanee-not that the loss of two or three pounds in the fleeve was not an object, but still he thought that if to preserve this the farner not only lost ten or twelve pounds of mutton by it, lut had to feed lis sheep for twelve or eightecn montlss longer than he ought, he wonld pay dearly for his three pounds of wool extra. Mr. Bakewell was right; and on these prineiples he addressed himself to his task.

The improved Leicesters are not adapted for scanty pasturage, over 
whieh the sheep must travel all day in order to proeure a suffieieney of food. They require a good, or at least moderate soil, and on this they fatten with ineredible rapidity, and are eonsequently very profitable to the breeder. If in the establishment of this breed Mr. Bakewell erred, it was in the very little regard lie paid to the wool, in whieh his inmediate followers innitated him, soine even going so far as to prefer sheep with bad fleeces to those with good, as if a fine and perfect eareass and good wool were ineompatible with eael other. But this false notion is now eorreeted, and the fleee obtains its due share of attention.

With respeet to tlue quality of the mutton of the improved Leicesters, we do not estimate it so highly as that of some of the short-wooled breeds. When not over fat, it is tender and jnicy, but destitute of ligh flavor; but when fattened to a bigh degree, the interstiees of the fibers of the museles are replete with fat in sueh a manner that the line of distinetion between fat and lean is almost, as it were, lost; the eareass appears to be a mass of fat, and is any thing but attraetive. Besides, such meat is not profitable to the pureliaser, though it may be to the eook. We admit, however, that it is the grazier's fault if he earries the fattening proeess beyond the point at whieh he ought to stop, whetluer he regards his own profit or the interest of the consumer. It is the eharaeter of the breed to ripen early and quiekly. $\Lambda$ s soon as the sheep are in a proper eondition for the buteher, the grazier, instead of wasting more food upon them, sliould get rid of them, and eommenee the feeding of anotlier lot, to be disposed of in their turn, as soon as ready.

It is for the aeenmulation of outside fat that the Leieesters are eliefly remarkable. They bave eomparatively little loose inside fat or tallow -a point of some consequenee to the butelier, who deems this as adding to his profit. By way of a eomterbalanee, lowever, the smallness of the head, the thinness of the pelt, and the general greater weiglit of the eareass than the appearanee of the animal would indieate, should be taken into eonsideration. Whatever it may be to the buteher, "this diminution of offal is advantageous to the grazier"; for it shows a disposition to form fat ontwardly, and is mitormly accompanied by a tendeney to quiekness of improvement." In this latter quality the new Leieesters, cateris paribus, are unrivaled.

The new Leicesters, with all their good qualities, are not a hardy raee, neither are they so prolifie as many other breeds. The ewes seldom produee twins, nor indeed did the founders of this stoek deem the production of twins desirable. They aimed at bringing forward the lamb as early as possible, and riglitly consilered that few ewes eould produce two suel, lambs as would meet witl their wishes and realize their object. The faet, moreover, is, that the exclusive attention paid to the establishment of a race, the vital energies of which were to be exhibited in the attaimment of early maturity, and in the quick aceunulation of fat, while produetive of the results aimed at, neessarily entailed counterbalaneing deficieneies. A tendeney to rapid fattening and carly ripenoss is not eoexistent, as a general rule, with great fertility. In this point, then, the new Leieesters are defeetive, but less so than for- 
merly. Still the ewes do not yield any great abundanec of milk, and the lambs are tender, delicate, and unfitted to endure any great incleneney of weather.

As a whole the Nrw Leicesters have not sueceeded so well in this eountry is in England, owing to the severity of our winters and to the beat and dryness of our summers. They do not find that luxmianee and abundanec in our pastures so neeessary to their highest thrift. Their flesh has not sufficient admixture of lean to be palatable to our people. The breed, howerer, sueeeds well in rich lowland pastures, and yields a profitable return.

The Sonth-Downs, - Formerly the Sonth-Down sheep were very indi ferent; it is true that they earried very fine rool, but then the carcass was ill-forned, a disadrantage which more than counterbalaneed the exeellence of the flece. 'They were small, thin in the neck, high in the shoulders and in the loins, down on the rmmp, with the tail set very low; the back was slarp, the ribs flat, and the fore-quarters narrow; yet there were materials to work upon, and besides, these sheep had some excellent qualifieatious; they arrived at early maturity, were extremcly bardy, thrived upon seanty keep and short feed on the natural pastures, and the inutton was fine-grained and of good flavor.

Attempts were first inade to improre on Sontl-Downs by erosses with the Leicesters, a long-wooled sheep, but these attcinpts ended in ntter failure, nor were crosses between them and the Merinos ultimately advantageous. It was by eareful selections, and the keeping in view of a definite purpose in the cloiee of breeding-stock, that the improrement of the Sonth-Downs was aclieved. It is to Mr. Ellman of Glynde that the elevation of this breed to its unrivaled position in its own line as a hill sheep is due.

Mr. Culley, in his "Live Stoek," 1807, notiees the exertions "of the ingenious Mr. Ellman, whose flock is already superiol to that of most of lis neiglibors, both in earcass, quantity, and quality of "rool." This enterprising and skillful breeder did not, bowever, content himself with mediocrity; and in the Annals of Agriculture, Mr. A. Young thus speaks of Mr. Ellman's Sonth-Downs: "His flock, I inust obscrve, is inquestionably the first in the eountry, the wool the finest, and the earcass the best proportioned. Both these valuable properties are united in the floek at Glynde. He has raised the merits of the breed by lis unremitting attention, and it now stands unrivaled." Mr. Ellman's own deseription of them is very unpretending. Ile says: "They

- are now inuch iniproved botl in shape and eonstitution; they aresmaller in the bone, equally hardy, with a greater disposition to fatten, and mnels heavier in eareass when fat. Tliey used seldom to fatten until they were four years old; but it would now be a rare sight to see a pell of Sontl-Down wetliers at inarket more than two years old, and many are killed before they reach that age." Doubtless the age is reckoned, as is usial with sleep, not from the time when lambed, but from the time of the first shearing.

The arerage dead weight of Sontl-Down wethers, varies from 100 to 150 pounds. They are very healthy and hardy, seldom affeeted with the rot and the diseases eommon with other varieties. 


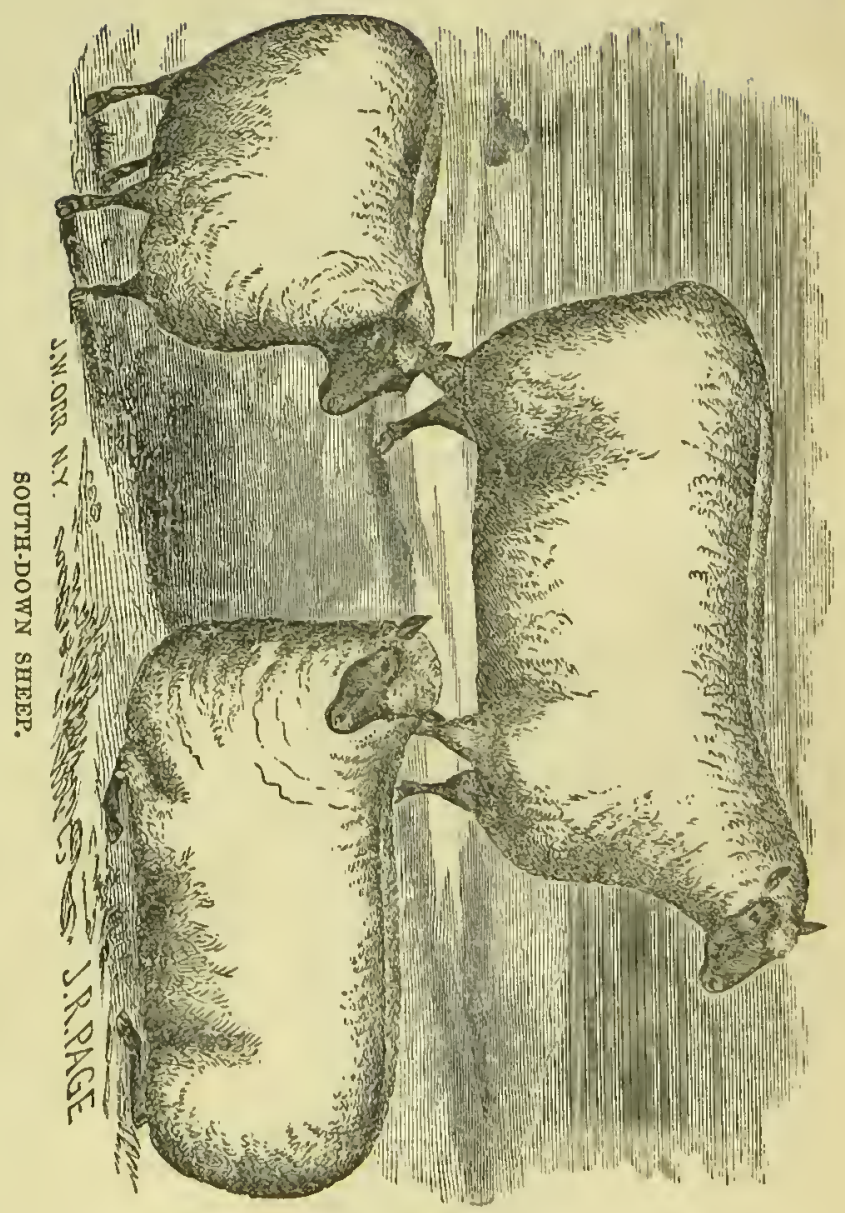


This animal has a patience of occasional short keep, and an endurance of hard stoeking searcely surpassed by any other sheep, an early maturity not inferior to that of the Leicesters, the flesh finely grained, and the wool of the most useful quality.

The avelage weight of the flecee of a South-Down hill sheep was stated by Mr. Lueeoek, in 1800, to be two pounds; it has now increased to three pounds. The fleece of the lowland shecp, that nised to be three pounds, is now three and a half, or even four pounds. 'I'his is the natural consequence of the different mode of feeding, and the larger size of the animal. The length of the staple in the hill sheep rarely exceeder two inches, and was oftenel not more than one and a half inches: it is now more than two inches, and in some of the lowland sheep it has reached to four inches. The number of hill sheep had rather deereased sinee 1800, and those in the lowlands had materially so; but now that Sonth-Down wool is onee more obtaining a remumerating price, the flocks are becoming larger than they were. The color of the wool differs materially, aceording to the eolor of the soil. The shortest and the finest wool is produeed on the chalky soil, where the sheep liave to travel far for their tood; but tliere is a hardness and a brittleness about this wool which was always seriously objected to.

The grcater comparative bulk of the fiber, and paueity of serrations, will aecount for the harshuess and want of felting property, which have been considered as defeets in this wool. The brittleness of the pile is, perhaps, to be attributed eliefly to the soil. The elothiers were always careful not to use too much of it in the making of their finest cloths. When most in repute, the South-Down was prineipally devoted to the manufacturé of servants' and army clothing, or it was sparingly mixed with other wools for finer elotl. Now, lowever, when it is materially increased in length, and beeome a combing wool, and applicable to so many unore purposes than it was before-now that it cuters into the composition of flannels, baizes, and worsted goods of almost every deseription-its fineness and its felting, compared with some of the other short wools, render it a truly valuable article. The South-Down sheepmaster justly repndiates the eharge of its deterioration-it has only changed its character-it has become a good combing wool, instead of an infurior carding one; it lias become more extensivaly useful, and therefore inore valuable; and the time is not far distant wlieu the slicep. owner will be convineed that it is his interest to make the South-Jowu wool even longer and lieavier than it now is. A sheep possessing such qualities must of eomse be valuable in upland districts, in the vicinity of markets. They have been introdueed into every part of the I3ritish dominions, and imported into various other countries. The Emperor of Russia paid Mr. Ellman three hundred guineas for two rams, and in 1800, "a ram belonging to the Duke of Bedford, was let for one season at eighty guineas, two others at forty guineas each, and fonr more at twenty-ejght gnineas each." These valuable sleep were jutrodured into the United States a few years since by Col. J. H. Powell, of Pliladelplia. and a small number were imported in 1834. The last were from the flock of Mr. Ellman, at a cost of $\$ 60$ a head. Several other importations have since taken place. 
The Cotswold Sheep.-The Cotswold is a large breed of sheep, with a long and abundant fleece, and the ewes are very prolifie and good uurses. Formerly they were bred only on the lills, and fatted in the valleys of the Severn and the Thames; but witl the inclosure of the Cotswold Hills and the inprovement of their cultiration they have been reared and tatted in the same district. 'They liave been extensively crossed with the Leicester slieep, by which their size and fleece bave becn somewhat diminished, but their carcasses considerably improved, and their maturity rendered earlier. The wethers are now sometimes fattened at fourteen montls old, when they weigl from fifteen to twenty-four pounds per quarter; and at two years old increase to twenty or thirty pounds. The wool is strong, mellow, and of good eolor, though vather coarse, six to eight inches in length, and from seven to eight pounds per fleece. The superior liardihood of the improved Cotswold over the Leicester, and their adaptation to common treatment, together with the prolific nature of the ewes and their abundance of milk, have rendered them in many places rivals of the New Leicester, and have obtained for them, of late years, more attention to their selection and general treatment, under which management still farther improvement appears very probable. They have also been used in crossing other breeds, and, as before noticed, have been mixed with the Hampshire Downs. It is, indeed, the improved Cotswold that, under the term new or improved Oxfordshire sheep, are so frequently the successful candidates for prizes offered for the best long-wooled sheep at some of the principal agricultural neetings or shows in the kingdom. Tlie quality of the inntion is considered superior to that of the Lcicester, the tallow being less abundant, with a larger development of muscle or flesh. We may, therefore, regard this breed as one of established reputation, and extending itself throughout every district of the country.

The Cheviots.-This breed has greatly extended itself throughout the mountains of Scotland, and in many instauces supplanted the blackfaced breed; but tle cliange, though in many cases advantageous, has in some instances been otherwise, the latter being somewhat hardier, and more capable of subsisting on heatly pasturage. They are, however, a hardy race, well suited for their native pastures, bearing with comparative impunity the storns of winter, and thriving well on poor keep. Thouglı less liardy than the black-faced sheep of Scotland, they are more profitable as respects their feeding, making more flesh on an cqual quantity of food, and making it quicker. They have white faces and legs, open countenances, lively eyes, without horns. The cars are large, and somewhat singular, and there is much space between the ear's and eyes. The carcass is long; the back straight; the shoulders rather light; the ribs circular; and the quarters good. The legs are small in the bone and covered with wool, as well as the body, with the exception of the face. The Cheviot wether is fit for the butcher at three years old, and averages from twelve to eighteen pounds per quarterthe mutton being of a good quality, though inferior to the South-Down, and of less flavor than the black-faced. The Cheviot, thongh a mountain breed, is quiet and docile, and easily managed. The wool is coarse and inferior to that of the South-Down. 
COMPARATIVE VALUE OF THE DIFFERENT BREEDS OF SHEEP.-On this subject we quote the careful, and to us convincing reasoning of H.S. Randall, Esq., contained in "The Sheep Husbandry :"

"In instituting a comparison between breeds of sheep for wool-growing purposes, I will, in the outset, lay down the obviously incontrovertible proposition that the question is not what variety will shear the heaviest or even the most valuable fleeces, irrespective of the cost of production. Cost of feed and care, and every other expense, must be deducted, to fairly test the profits of an animal. If a large shicep consume twice as much food as a small one, and give but once and a half as much wool, it is obviously more profitable, other things being equal, to keep two of the sinallest sheep. The true question then is, witl the same expense in other particulars, from what breed will the verdure of an acre of land prodnce the greatest value of wool ?

"Let us first proceed to ascertain the comparative amount of food consumed by the several breeds. There are no satisfactory experiments which slow that breed, in itself considered, has any particular influence on the quantity of food consumed. It is found, witl all varieties, that the consumption is in proportion to the live weight of the (grown) animal. Of course, this rule is not invariable in its individual application, but its general soundness has been satisfactorily established. Spooner states that grown sheep take up three and one-third per cent. of their weight in what is equivalent to dry hay per day, to keep in store condition. Veit places the consumption at two and a half per cent. My experience would incline me to place it abont mirlway between the two. But whatever the precise amount of the consunption, if it is proportioned to the weiglit, it follows that if an acre is capable of sustaining three Merinos weighing one hundred pounds each, it will sustain but two Leicesters weighing one hundred and fifty pounds each, and two and two-fiftlss South-Downs, weighing one hundred and twenty-five pounds each. Mcrinos of this weight often shear five pounds of tleece, taking flocks throngh. The herbage of an acre, then, would give fifteen pounds of Merino wool, and but twelve pounds of Leicester, and but nine three-fiftlss pounds of Soutlı-Down (estimating the latter as ligh as four pounds to the fleece)! Even the finest and lightest fleeced sheep ordinarily known as Merinos, average about four pounds to the fleece, so that the feed of an acre would produce as inuch of the highest quality of wool sold under the name of Mcrino, as it would of New Leicester, and more than it would of Sonth-Down! The former would be worth from fifty to one hundred per cent. more per pound than either of the latter! Nor does this indicate all the actual difterence, as I have, in the preceding estimate, placed the live-weight of the English breeds low, and that of the Merino high. The live-weight of the four pound fine fleeced Merino does not exceed ninety pounds. It ranges from eighty to ninety pounds, so that three liundred pounds of live-weight would give a still greater product of wool to the acre.* I consider it perfectly safe to say that the herbage of an acre will uniformly give

* It is understood that all of these live-weights refer to ewes in fair oldinary, or what is called store condition. 
nearly double the value of Merino, that it will of any of the English long or middle wools.

"The inportant question now remains, What are the other relative expenses of these breeds? I speak from experience when I say that the Leicester* is in no respect a hardier sheep than the Merino-indeed, it is my firm convietion that it is less hardy, muder the most favorable circumstanees. It is more subjeet to colds, and I thiuk its constitution breaks up more readily under disease. The lambs are more liable to perish from cxposure to cold, when newly dropped. Under unfavorable cireumstances-berded in large floeks, pinelied for feed, or subjected to long journeys -its eapacity to endure, and its ability to rally from the effects of such drawbacks, do not compare with those of the Merino. The high-bred South-Down, though considerably less hardy than the unimproved parent stock, is still fairly entitled to the appellation of a lardy animal. In this respect, I eonsider it just abont on a par with the Merino. I do not think, however, it will bear as hard stocking as the latter, withont a rapid diminution in size and quality. If the peculiar merits of the animal are to be taken into account in deternining the expcnses-and I think they should be-the superior fecundity of the South-Down is a point in its favor, as well for a wool-producing as a nutton sheep. The South-Down ewe not only frequently yeans twin lanbs, as do both the Mcrino and Leicester, but she possesses, unlike the latter, nursing propertics to do jnstiec by them. But this advantage is fully counterbalanced by the superior longevity of the Merino. All the English mutton breeds begin to rapidly deteriorate in amount of wool, capacity to fatten, and iil general vigor, at about five years old, and their carly maturity is no offset to this, in a sheep kept for woolgrowing purposes. This carly decay would require earlier and more rapid slanghter or sale than would always be ceonomically convenient, or even possible, in a region situated in all respects like the South. It is well, on properly stocked farms, to slaughter or turn off the Merino wether at four or five years old, to make room for the breeding stock; but he will not particularly detcriorate, and he will riehly pay the way with his fleece, for several years longer. Breeding ewes are rarely turned off before eight, and are frequently kept until ten years old, at which period they exhibit no greater marks of age than do the Down and Leiccster at five or six. I have known instances of Merino ewes breeding uniformly until fifteen years old! The inproved Cotswold is said to be hardier than the Leicester; but I have said less of this variety, throughont this entire letter, as from their great size $\dagger$ and the consequent amount of food consumed by them, and the other neecssary incidents eomected with the brecding of so large animals, the idea of their being introduced as a wool-growing sheep anywherc, and particularly on lands grassed like those of the South, is, in my judgment, utterly preposterous. There is one advantage which all the coarse races of

\footnotetext{
* I speak of full-blooded Leicesters. Some of its crosses are much hardier than the pure bred sheep.

$\nmid$ I saw two at the late New York State Fair, at Saratoga, which woighed over three hundred pounds each.
} 
sheep have over the Merino. Either because their hoofs do not grow long and turn under from the sides, as do those of the Merino, and thus hold dirt and filth in constant contact with the foot, the coarse races are less subject to the visitations of the hoof-ail, and, when contracted, it spreads with less violence and malignity among them. Taking all the eircumstances connected with the peculiar management of cach race, and all the incidents, exigencics, and risks of the lusbandry of cacli fairly into account, I am fully convineed that the expenses, other than those of feed, are not smaller per capita, or even in the number required to stock an acre, in either of the English breeds above referred to, than in the Merino. Nor should I be disposed to concede even equality, in these respects, to either of those English brecds, excepting the Sonth-Down.

"You write me, sir, that many of the South Carolina planters are nnder the impression that coarse wools will be most profitably grown by them, first, because there is a greater deficit in the supply, and they are better protected from foreign competition; and, secondly, because they furnish the raw material for so great a portion of the woolens consumed in the South. Each of these premises is true-but are the conclusions legitimate? Notwithstanding the greater deficit and the better protection, do the coarse wools bcar as higl a price as the finc oncs? If not, they are not as profitable, for I have already shown that it costs no more to raise a pound of coarse than a pound of fine wool. $\mathrm{Nay}$, a pound of medium Merino wool can be raised more cheaply than a pound of the South-Down, Leicester, or Cotswold! This I consider clearly established.

"Grant that the South requircs a inuch greatcr proportion of coarse than of finc wool, for her own cousunition. If a man nceding iroul for his owu consumption wrought a mine to obtain it, in which he should liappen to find gold cqually accessible and plentiful, would it be cconomical in him to neglect the morc precious metal because he wanted to use the iron? or should he dig the gold, obtain the iron by cxchangc, and pocket the difference in value? Would it be economical to grow a surplus wool, wool for market, worth from twenty-five to thirty cents per pound, when it costs no more per pound to grow that worth from forty to forty-five cents? And even for the home want, for the uses of the plantationfor slave-cloths, etc. - fine wool is worth more per pound than coarse for actual wear or use! Is this proposition new and incredible to you? I challenge the fullest investigation of its tmith, through the testimony of those familiar with the subject, or through the direct ordeal of cxperiment. It is true that a piece of fue broadcloth is not so strong, nor will it wear like a Chelmsford plain of treble thickness. The threads of the former are spun to extreme fincuess to cconomize the costly raw material. To give it that finish which is demanded by fashion-to give it its beantiful nap-these threads are still furtlier rednced by "gigging" and "shcaring." But spin finc wool into yarn as coarse as that used in Chelmsfords, and manufacture it in the same way, and it would make a far stronger and more durable cloth. The reasons are obvious. Mferiuo wool is decidcdly stronger than the English coarse long and middlc wools-or any other coarse wools-in proportion to its diameter or 
bulk. It felts far better, and there is thercfore a greater cohesion between the different fibers of the same thread, and between the different threads. It is also more pliable and clastic, and consequently less subject to "breaking" and abrasion.

"Unless the views I have advanced are singularly erroncous, it will be scen that, for wool-growing purposes the Merino possesses a marked and decided supcriority over the best breeds and families of coarsc-wooled sheep. As a mutton slieep, it is inferior to some of those breeds, but not so mucl so as is generally supposed. If required to consume the fat and lean together, many who have never tasted II crino mutton, and, who have an unfavorable impression of it, would, I suspect, find it more palatable than the luscious and over-fat New Leicester. The mutton of the cross between the Merino and "Native" sheep wonld ccrtainly be preferred to the Lcicestcr, by any body but an English laborcr used to the latter. It is short-grainel, tender, and of good flavor. The saine is true of the crosses with English varicties. These will be hercafter, more particularly alluded to. Grade Merino wethers (half-bloods) are favorites with the Northern drover and butcher. They are of good size-extraordinarily heavy for their apparent bulk* - make good inutton-tallow well-and their pelts, from the greater weight of wool on them, command an extra price. They would, in my opinion, furnish a mutton erery way suitalble for plantation consumption, aud one which would be well accepted in the Southern markets.

"In speaking of the Merino in this connection, I have in all cases, unless it is distinetly specified to the contrary, had no reference to the Saxons-though they are, as it is well known, pure-blooded deseendents
of the former."

GENERAL MANAGENENT OF SHEEP.-Their Summer Nanagement,-The change in spring from dry to succulent food, produces in all sheep a certain degree of scouring, and which, if precautions have not been taken to guard against it, soils the wool on the hinder parts of sheep, and its subsequent renoval becomes difficult. To prevent this, every sheep before being turned to grass in the spring slould have that portion of the wool which is liable thus to become soiled carefully clipped away, including that which immediately surrounds the roots of the tail, cover's the thighlis, the bags of the ewes, ete. This operation sives the wool, which would otherwise be lost, the :uimal much subsequent suffering, and the owner much labor. Tagging sheep, therefore, should not be neglected by any carcful shepherd.

It is scarcely necessary to say that the fields in which shecp are to run should be carefully cleaned of every variety of burr, by which so much wool is annually lost in this country, being so matted together with them as to be of little comparative value.

Care in the hindling of Shepp should always be cxcreised. They never should be lifted by the wool, for, as the skin adheres so loosely; it is often separated from the body by the act of lifting, and blood hats often been found settled beneath the parts thus improperly handled. The legs or necks of sheep are the parts by which only they should be seized:

* On account of tho shortness of their wool, compared with the coarse breede. 
and for catehing shecp the sliepherd's erook is a very simple yet very convenient instrument. It is thus deseribed by Mr. Stephens:

"The hind leg is hooked in from behind the shecp, and it fills up the narrow part beyond while passing along it until it reaches the loop, when the animal is eaught by the hock, and when sccured, its foot easily slips througlt the loop. Some cantion is required in using the crook, for, should the sheep give a sudden start forward to get a way the moment it fecls the crook, the leg will be drawn foreibly through the narrow part, and strike the bone witl sueh violenee against the bend of the loop as to cause the animal considerable pain, and even occasion lameness for some diys. On first embracing the leg, the erook should be drawn quickly toward you, so as to bring the bend of the loop against the leg as high up as the hock, before the sheep has time even to break off, and being seeure, its struggles will cease the moment your hand seizes the leg."

The Season of Lambing requires the shepherd's espeeial eare. From the first to the middle of May is the best season. In the general course of breeding, however, it is desirable that the lambs should not fall until the cold of winter is over, and the pasture begins to afford some food for the little ones. This is peeuliarly important in bleak and exposed situations. Thousands of lanbs die every year from the cold to which they are exposed as soon as they are yeaned. On the other hand, there nay be some ineonvenience and danger if the period of lambing is too late. Hot weather is as fatal to the mother as eold is to the offspring. It frequently induees a dangerous state of fever; and both the mother and the lamb may be then injured by the luxuriance of the grass. If the lamb falls late in the season, it will be longer ere the ewe can be got ready for the butchcr, and the ground cleared for other stoek; and; in addition to this, the early lambs become larger and stronger, and better able to resist the eold of the succeeding winter. The yeaning time will, therefore, be regulated by the situation of the farm, the nature of the pasture, and the demand from the neighboring markets.

The duration of pregnancy is about five months, or one hundred and filty-two days, with eomparatively little deviation. As the end of this period approaches-and it slionld not be a matter of memory merely, but of record-the flock should reccive the grazier's watehful attention. The ewes slould be separated from the rest of the flock, and in an inclosure, in which is a sherl or covert from the storms, which are so eommon, and so destructive to young lambs.

Care of the Lambs. - It is the duty, and would be the interest, of the farmer to attend to the confort of his ewes and lambs at this period; the lanbing-field shonld always be a sheltered one, and there should be a temporary or a permanent retreat for the weakly and the cold. The first cale of the shepherd therefore should be to examine the ncwlydropped lamb. If they are chilled and searcely able to stand, he should give them a little of the rnilk, which he carries always with him, and then take them to some shelter, or plaee them in a basket well lined with straw. Nursing of this kind for an hour or two will usually givo the animal sufficient strength to rejoin its mother. 
Nature has given to the sheep, as well as to other animals, an instinetive and strong affection for its young; an affection which strengthens in proportion to the necessities of the parent and the offspring. The more inhospitable the land is on which they feed, the greater their kindness and attention to their little ones; nevertheless, it will oceasionally happen that the young ewe, in the pain and eontision and fright of her first parturition, abandons her lamb. Some, when the udder begins to fill, will seareh it ont again, and with unerring preeisionothers, severed from their offspring before they had become aequainted with its form and seent, are cagerly searehing for it all over the field with ineessant and piteons bleatings. Some will be hanging over their dead offspring, while a few, strangely forgetting that they are mothers, are grazing unconeernedly with the rest of the flock.

There is another eireumstance that alds to the confusion. Some of the ewes have had twins; they have inalvertently strayed from one of them, or stupidly $\mathrm{ol}^{\circ}$ eapriciously have driven it from them; and the neglected one is wandering alout, vainly seeking its parent, or angrily repulsed by it.

'The first thing a lamber' has to do is to remedy as well as he ean this confusion. IIe first seeks ont for those that have twins, and that hase recognized both of their lambs, and, taking his little marking-bottle and unarking-iron, he puts a particular mark on each of the twins, by which he may again recognize them, and on each pair he puts a different mark. If they are just dropped, and are weak, lie leaves them for a wlite; but if they are able to travel a little, he drives them into a pound, or into a corner of the field with the other twins, or he at onee remores them into another and somewhat better pasture, which he had destined for the twins.

He then looks for the lambs that have apparently been abandoned by the nother, and if, as he takes one of them up, it bleats, he will presently find whether there is any responsive eall or gaze of recognition. If the mother eagerly calls to it, he has but to put it down, and she will speedily rejom and suekle it, if it is strong enough to raisc itself from the ground for this purpose. If the animal is almost exhausted, he must eateh the ewe, and assist her to snekle the lamb. It will soon revive, and her love for it will revire too. If she merely gives a carcless look of recognition, he must suekle the lamb fiom his bottle of ewe's milk, and leave it for a while; perhaps her affeetion will return when her udder begins to be distended with milk; it not, he must drive her with others into a fold, and, suffering the rest to eseape, try every means to induce lier to let the little one suck. 'There may be considelable diflienlty in this at first, but, by the exereise of some patienee and tact, he will generally suceed. After all, however, he will probubly have some lambs upon his hands for whom he cannot find at mother; or whose own mother will not suckle them.

On the other hand, he will find some ewes who are gazing mournfully on their dead lambs. With some contrivance, he will generally find in these foster-mothers for his abandoned ones. He ties a piece of cord round the hind fect of a dead lamb, and the mother, if she lias not been unnecessarily frightened by the lamber, or his dog, will follow 
for miles with her nose elose to the lamb, and inay be led wherever the shepherd chooses.

The Su!stitute Lamb.- The bereaved and affeetionate ewe is induced to follow the remains of lier little one to the lambing pound, or to some other eonvenient plaee. A lamb that has lost, or been abandoned by its nother is then selected. The head, tail, and legs of the dead lamb are cut off; an ineision is made along the belly, and the body turned out, and this skin is then drawn over the substitute lamb. The body of the dead lamb is opencd, the liver taken out, and the head and legs of the living lamb, and what other parts the skin does not eover, are smeared with blood. In the darkness of the night, and after the skin has been warmed on it, so as to give something of the smell of her own progeny, the substitute is put to the bereaved ewc. In the majority of cases the fraud is altogether successful, and the impostor is at once reecived, and fondled, and suekled. This being effectcd, the shepherl hastens to remove the false clotling; the lanib is returned to her, and "whether it is from joy at this apparent rcanimation of her young one, or beeause a little donbt remains on her mind, which she would fain dispel, eannot be decided; but for" a number of days she shows more fondness by bleating over and caressing this one, than she did formerly over the one that was really her own."

If she does not take to it at first, she must be compelled to suekle it, and confined so that she shall not be able to kick or otherwise hurt it. In two or three days sle will generally own it, and then they may be turned together into the field without any apprehension or trouble.

Care, however, should be taken that the age of the substitute lamb and that of the true one should eorrespond as nuch as possible. If a lamb lately dropped is put to a ewe whose young one would have been a weck or two old, the nilk will be too strong, and a purging will be set up, whieh, probably, no medieine can arrest. On the other hand, if the substitute lamb is a week or two old, and the foster-mother had lost hers in the act of yeaning, her milk will be injurious on aecount of that purgative quality by which the intestines of the newly-dropped lamb are tirst excited to action. Sometimes the foster-lamb, frightened or exhausted, will not readily take the teat, however disposed the ewe may be to adopt and feed it. Care should be taken to aseertain whether this is the ease, and, if necessary, the lamb should be held while a little of the milk is pressed into its mouth from the udder. This will rarely need to be repeated, for instinct will teach it where to seek and how to obtain its proper nutriment.

After-lire of the Lambs,-In the eourse of a little more than a week, the great majority of the ewes will have produeed their young, and the lamber will have more leisure for those eases which particularly require his attention. The twin-field will particularly demand his eare. Ho will seldom enter it on the morning without finding some degree of confusion. Some of the lanbs will have strayed from or been abandoned by their mothers; and these twin-mothers are sometimes not a little eapricious, and especially when, not having sufficient milk for the two, they are teased and worried by the ineessant sucking of the twins. In such ease they will, in the most determined and furious inanner, repulse one 
of them. Anid the intermingling of the offspring of the different $\mathrm{ewes}$ he will find the advantage of having marked the respective twins, and thus, although not always without regularly drawing them off, he will be enabled properly to separate the respeetive families: he will relieve the weakly ewe from a burden which slie eannot support; and, on the other hand, he will reeoneile the deserted little one to its unnatural parent, or find a better nother for it. The ewes with their single lanbs will not, after a few days, require any extraordinary degree of tronble, hut those with twins inust be earefully watehed, at least until the lambs begin in good carnest to graze. Many a lamb has been stinted in its growth, and irreparably injured, by the insufficient supply of milk which the ewe with twins ean afford.

Twins.-This is the proper place to speak of the desirableness of having many twins. Most breeders are partial to them, on aceount of the apparent rapid inerease of the flock, or the additional quantity of lambs that ean be prepared for the market. The question depends entirely on the quantity of land which the farmer holds, and the nature of the soil. If he has pasture enough, and good enough, twins are highly desirable; for at only the usual expense betore the yeaning time, the number of his lambs is doubled, and, the pasture being good and the lambs well fed, there will be very little differenee in health, condition, or value, between the twins and the single lamb.

The ewe seldom has twius at her first yeaning; and it is fortunate that she has not; for it is seldom that she has any great supply of milk then, and, consequently, the mother and her offspring would equally suffer. The twins are generally obtained from ewes that are three, four, or five years old. The disposition to twinning is mudoubtedly hereditary. There are ecrtain rams that have the credit of being twingetters, and that faculty usually descends to their offspring; but this is oftener the ease with regard to the ewe, agreeably to the old couplet:

" lives. yearly by twinning, rich masters do make:

The lambs of such twinners for breeders go take."

'The female of' every speeies of animal has far nore to do with this unnsual multiplication of the offspring than has the male; and the farmer who wishes rapilly to inerease his stock through the inedium of twins, may go some way toward the aecomplishment of his olject by placing his ewes on somewhat better pasture, or allowing them a few turnips when November approaches.

The llinagement of the Lambs_We return once more to the lanbs, now a few days old. The old ewes will prove assiduous and faithful nurses, but the young ones will oceasionally wander from their lambs, and prove inattentive to or have not reeognized their bleatings. Sueh mothers must he separated from the Hock, and folded and confined with their young ones, until they appear to be disposed faithfully to do their duty. Some lambs refuse the attention of the mother, and lie weak or sullen, and droop away and die. Some of the mother's milk should be frequently introdueed into the mouth; and, if that lias not the desired effeet, a foster-mother must, if possible, be found; or the little churl must be brought up by the liand. There will, generally' speaking, ho very 
little diffieulty abont this. If it is at first fed with warm sheep's or eow's milk, by means of a spoon, until it is old enough to snek ont of a sueking-bottle, it will soon begin to bleat for its food, and greedily ineet the bottle the moment that it is presented to it.

The cuckoo lambs will require the partienlar attention of the shepherd. They are those that are dropped later than the others, when the euekoo is just making his appearance, and after whom they are named. They are nsually the progeny of very young or very old mothers, who were not impregnated so soon as the others, and who generally are not so strong and so hardy as the rest of the flock. Care must be taken that they have sufficient, yet not too nutritive food; and that the diseases to which weakly lambs are subjeet are promptly attender to.

Some ewes will permit other lambs beside their own to snek them, and then there will possibly be one or more greedy lambs, who will wander abont from ewe to ewe, robbing the righth ful owner of the greater part of his share. Ile and his mother mnst be removed to another pasture, where lic will soon learn to sati.fy hiv roracions appetite with the grass. $\Lambda$ s the slepherd takes his romind he shonht inspeet every lamb. If one does not appear to thrive, he shonkl enteavor to ascertain the eause. IIas the mother any or suflicient milk? Are the teats fire from disease? He should either supply the deficient nutrinent, or provide a foster-mother. Does the milk disagree with the lamb? Is there any or eonsiderable purging? The ealves and shep's cordial must be inmediately resorted to; and, if neessary, nursing, or separition trom the mother. In two or thrce weeks, and often considerably sooner, the lambs will begin to nibble a little gries. Is it too luxuriant for them, or has it been eaten down elose by the ewes, and is the owner thinking of providing a fresh pasture? Let him beware! There is no situation in which the old adriee of not making "more haste and good speed" should be more earefully heeded than in this. If one paraunount cause of disease, and fatal disease to lambs, were selected, it wonld be a sudden change from bare to huxuriant pastnre. It often sets up a degree of inflammatory fever, which no depletion will extinguish, or a diarrhoea whieh no astringent ean cherk.

'The teelnieal term whieh the shephord applies to the lamb diseased from this canse is yall-lamb. 'The, liver seems to be the principal seat of inflammation, and a great quantity of bile or yall is found in the duodenum and small intestines; a portion of it has frequently regurgitated in to the abomasum or fourth stomach, and some has ontered into the eirculation, and tinged the skin and tlesh of a yellow eolor. It is a discase whieh very specdily runs its eomrse; ocensionally currying off its vietims in a little more than twelve honr's, and sellom lasting more than three days. Innediate bleeding in the early stage, and afterward Epsom salts, with a small portion of ginger, will afford the only clianee of a enre. The poor animal is often condemned and slanglitered at once-that is ballbarous work.

Custration,-There is a great difference of opinion as to the time when the tup-lambs that are not intended to be kept for breeding should be castrated. Some reeommend the performance of this operation as early as three days after the birth. Mr. Parkinson says that "he has several 
times cut a lamb the very day that it was lambed, when strong and healthy, and that he never knew one do ill from the opcration." The proper period depends a great deal on the weather, and on the stoutness of the lamb, and varies from the third or fourth to the fourtcenth or twenty-first day, the weather bcing cool or cven cold, and somewhat moist. It would be highly improper and dangerous to select a day unusually warm for the season of the year. The absence of unusual warmth, and the health of the animal to be operated upon, are the circumstances which should have most influence in determining the time.

There are two methods of performing the operation. The lamb being well secured, the operator grasps the serotum or bag, and forces the testicles down to the botton of it. He then ents a slit across the bottom of the bag, in a dircction from bchind forward, through the substance of the bag, and large enough to admit of the cscape of the testicles. They immediately protrude through the ineision, being foreed dow $\mathrm{by}$ the pressure above. The operator then seizes one of them, and draws it so far out of the bag that a portion of the cord is seen; and then, if hc is one of the old school, he seizes the cord between his teeth and gnaws through it. This is a very filthy practice, and inflicts some unnccessary pain. The testicle being thus scparated, the cord retracts into the scrotum, and is no more seen. The other testicle is brought out and operated upon in a similar manner. V Very little bleeding ensnesand the young one may be returned to its mother. An improvement on this operation, and which any one except of the lowest grade would adopt, is to usc a blunt knife instead of the teeth. By the sawing action which such a knife renders necessary, the artery is cren more completely torn than with the teeth; and yet without so innch bruising of the part, and probability of ensuing inflammation. It is by the laceration, instead of the simple division of the cord, that after-bleeding is prevented.

Another way of performing the operation is to push the testicles up toward the belly, and then, grasping the scrotum, to cut off a sufficient portion of the bottom of the bag to admit of the escape of the testi. cles when they are again let down. They arc, one after the other, pushed out, and taken off in the manner alrealy directed. The wound is considerably longer in healing when the base of the bag is thens cut away, and the animal consequently suffers more pain. 'The first is the prefirable way, if the incision is made sufliciently long to prevent its closure for two or three days, thus leaving an outlet for the escape of the blood and pus from the inside of the bag.

'There is usually little or no danger attending the operation, and yet occasionally it is strangely fatal. In a whole flock not a single lamb will sometimes be lost; but at other times the dcaths will be fcarfully numerous, the same person having operated on both oceasions. Much, probably, depended on some pceuliar state of the atmospherc, of the actual nature of which we know nothing at all; and more probably might he connected with a disposition to inflammation in the paticnt procecding from too high feeding, or from a debilitatch state of the frame, and which had not been observed or properly estimated.

When fatal discase oceurs aftcr castration it usually assumes the form 
of tetanus, or locked-jaw. The village operator pretends to tell when this will or will not supervenc. The usual struggles of the animal, or the usmal expressions of pain, he does not regard; but when, as he is grlawing the cord asunder with his teeth, he feels a deep and universal shudder of the aninal, he says at once that that lainb will die. $\mathrm{He}$ is often right about this, and when he is, it can be easily explained. By the fcarful torture he has inflieted, he has cansed a shock of the whole of the nervous system, from which the poor sufferer ean never perfectly recover.

Occasionally, when the lamb that was selected as a breeder does not turn out well, it is necessary, in order to fatten him and to make his flesh salable, to castrate him. There are various ways of performing this operation on the young or fully adult sheep. Some proceed precisely as with the horse. An ineision is made into the scrotum; the testicle is forced out, the iron clamps are put on the eord, which is then divided between the elamp and the testicle, and the cautcry is had recourse to in order to sear the part and prevent bleeding. This operation nsually succeeds well, but it is not every operator on sheep that has the clamps or the firing-iron.

The preferable way of operating is, to tie a waxed cord as tightly as possible round the scrotum above, and quite elear of the testicles. The circulation will here also be completely stopped, and usually in two or threc days the scrotum and the testicles will drop off. Accidents have occurred, but which are attributable to the operator; he has included a portion of the testicle in the ligature, and thus laid the foundation for very great and fatal inflammation; or he has used too large a cord, and which could not be drawn sufficiently tight; or the knot has slackened and the ligature has pressed sufficiently to producc excessive inflammation and torture, but not completely to cut off the supply of blooil. Carc being taken in the application of the cord to the exact part, and the tightening of the ligature, the animal secins searcely to suffer any pain; indeed, the nerves are evidently deadened by the compression of the cord, and no accident occurs.

Docking. - There is much variety of opinion amoung sheep-masters as to the time when this operation shonld be performed. Some, like Mr. Parkinson, think that it should be done within a very few days after the birth; the ewes on the first, second, or third day, and the male lainbs when they are castrated. The anthor of the "Complete Grazier" would defer it until the lambs are three or four montlss old. This inust depend on the state of the weather, and the healtl of the animals. No one slould doek his lambs when the weather is very cold, because the bushy tails of the animals afford a great deal of warmth. On this account, in particularly cxposed situations, it is deferred until the warm weather sets thoroughly in, and by some, and particularly with their cwes, not practiced at all. The tail certainly affords both protection and warmtl to the udier, and likewise defense against the dreadful annoyance of the flies in lot weather; but, on the other liand, it permits the accmmulation of a great deal of filth, and, if the lamb or the sheep should labor under diarrhoa, and the shepherd should be somewhat negligent, the tail may cling to the haunches, and that so closely 
as to form an almost insuperable olstruetion to the passage of the frees. It likewise can seareely be denied that the removal of the tail very mueh improres the beauty of the animal, by the fullness and widtb which it seems to impart to the haunches.

The operation is a very simple one. An assistant holds the lamb with its back pressing against his belly, and thus presenting the haunehes to the operator, who, with a knife, or a strong pair of seissors or forceps, ents it off at the seeond or third joint from the rump. A few asbes are then sprinkled on the wound-common flour would do as well, in order to form a coagulum over the part and stop the bleeding. It is seldom that the bleeding will continue long; but, if the lamb should appear to be growing weak in consenuenee of the loss of blood, a piece of twine ticd tightly round the tail, immediatcly above the doek, will at onee arrest the hemorrliage; the twine, however, must be removed twelve hours afterwarl, otherwise some sloughing will ensue, and eare must likewise be taken that the ineision is made preeisely in the joint, otherwise the wound will not heal until the portion of bone between the dock and the joint above has sloughed away.

Spayillg-A few weeks after eastrating the spaying of the rejected cwe-lanbs will succed, an operation wlricl will materially contribute to their inerease of growth and disposition to fatten. It is singular that this practiec should be almost confined to Great Britain and to Italy, for there ean be no manner of doubt of the advantage of it. Daubenton, howcrer, in his "Instruetions to Shepherds," gives a useful account of the manner in which it is best performed.

At the age of six weeks, the ovaries are grown suffieiently large to be casily felt, and that is the time nsually selceted for the spaying, being immediatcly after the first formal eximination of the floek. 'Tle lamb is laid on her right side, near the edge of a tablc, with her head hanging down by the side of the table; an assistant stretches out the left hind-leg of the animal, and holds it in that situation, with his left hand grasping the shank; and in defanlt of a second assistant, he. also holds the two fore-legs, and the other lind-leg with his right hand. The lamb being thus disposed, the operator, tightening the skin of the part, makes an ineision of an inels and a half in length, midway between the top of the haunch and the navel, and penctrating througb the skin; another incision divides the muscles of the belly and the peritoneum. $\Lambda$ careful operator will, perhaps, make threc incisions, the first throngh the skin, the seeond througl the abdominal muscles, and the third through the peritoneum. He then introduces bis forefinger into the abdoninal eavity, in search of the left ovary, which is immediately underneatl the ineision; and, having found it, he draws it gently out. The two broad ligaments, and the womb and the right ovary, protrude at the same time. 'The operator euts off the two ovaries, and returns the womb and its dependeneics; he then closes the womb by means of two or three stitehes through the skin, earefilly aroiding the abdominal museles below; and, last of all, he rubs a little oil on the wound, or he does nothing inorc, but relcases his patient.

The lamb very probably will be tinwilling, and perhaps will altogether refuso to suck or to graze during the first day, but on the follow- 
ing days he will fied as usual. In ten or twelve days the wound will have perfectly healed, and the threads may be cut and taken away. The only thing to be feared is inflammation of the peritonem, which was divided in the operation; but this rarely occurs, and, on the whole, there is not so much danger in the spaying of the ewe-lamb, as in the castration of the tup.

Sheep-Washing,-This is best done in vats constructed for the purpose, and where large flocks are to be washed, the expense and care are well repaid. These vats are to be so located as that the water can be conveniently let into them by sponts, and a small stream, dammed up, will answer the purpose. The vat should be about three and a half feet deep, and of such size as to admit two spouts to flow into it at the upper end, at which two inen can wash, while two others can be so employed at jts lower end and over which the water flows. The vat should have a gate to draw off the water as often as fifty sheep are washed. A platform should connect the top of the vat with the sheep-yards, of which there should be two, one to contain the nuwasherl, and the other the washed sheep; lambs, on account of their liability to accident, slrould not be driven with the flocks to the washing-pens. The operation of washing is facilitated, and rendered much easier by heary yains immediately preceding it, and which have thoroughly saturated the fleeces. Sheep are more generally injured while washing than in any other way, and hence, at this time the utmost care is nceded in handling them.

Sheep-Shearing.-This, in fuir weather, may be done in from five to six days after washing. The operation shonld always be carefully done, and by those only who are experts in the art. This is equally dictated by the true interest of the wool-grower-as by no other's can the fleeces be kept and put into proper merchantable shape-and by humanity, as clumsy shearers clip and imutilate, and otherwise often shamefully abuse the uncomplaining sheep.

Every thing being arranged, a sheurer seizes a sheep, and sets it on its rump, and keeps $j \mathrm{in}$ this position by resting the back against his own legs. He removes all straws, thorns burs, etc., that may liave adhered to the wool. While thus held, the wool is removed from the head and neck as far as the shoulders, and also from the belly, the scrotum, and the edge of the thighs. The head of the animal is then bent down sidewise, and the shearer, placing a leg on each side of the neck of the sheep, pushes out the opposite ribs by pressing his knees gently against the ribs that arc nearest to lijm. He next sliears the wool from the far side with his left hand, from the belly to the middle of the back, and as far down as the loins. The sheep is now turned, and the right hand is employed to shear the wool from the near sidc. The sheep is then laid flat on jts side, and kept down by the shearer with his face toward the rump of the sheep, resting his right knee on the ground in front of the neck, and lis right toe bcing brought to the ground a little behind and below the poll; the head and neck of the sheep are thus confined by his right leg, while he uses his right hand to shear the wool from the lijnd quarter. In this way the clips of the shears will appcar in concentric rings round the body of the sheep. The dirty portions of wool about the tail are then removed by the shears and kept by themselves; the 
ontside of the fleece is folded inward, beginning at the sides, and narrowing the whole fleece into a strip about two feet wide. This strip is then rolled firmly up from the tail cnd toward the neek.

WINTER MANAGENENT, - Sheds, to shicld sheep from eold rains, sleety storms, and from picrcing winds, are at onee dictated hy humanity and true eeonomy; but every arrangement for thus housing sheep should provide for free ventilation, as the health of nonc other of our domestic animals is so cntirely dependent on pure air as that of the sheep.

Winter Food.- Hay is the staple winter food of shecp in the United States. Morrell, in The American Shepherd, states the daily quantity, in eold weather, which a sheep weighing one hundred pounds will consume, at two and a half pounds; and if every one hundred sheep should have a daily supply of from six to eight quarts of eorn, or its equivalent in cut potatoes or other roots, the inereased thrit of the flock, and their larger return of better wool, would richly repay the extra cost and trouble.

When the foddering season arrives, the flock should be arranged into as many apartments as eireumstances will admit. A small one of the oldest and poorest should have the preference as to acconimodation and attention, and to it should be added oceasionally such as may from any ealse be deelining; and such as have sufficiently recruited in this departinent may give place to them. This flock should he fed with grain and roots, as their condition and cireumstances may require, through the wintcr. So with the lambs, a floek of the smallest and poorest shonld he managed in the same way.

When assorting and arrauging for the winter, the feet and tocs of all should be cut and trimmed to a proper shape; and the cnds of the horns of all such as incline to branch out should be sawed off. The wbole should have free aecess to water and salt through the winter, and should be fed with hay, in boxes, plentifully and regularly three times a day; under cover when cold or stormy, outside when fair, if morc eonvenient; and in rain-storms should be confined under cover. It is convenient to let them lave free access to straw, in boxcs, at all timcs, and oecasionally a change of the different kinds of hay and corn fodder. The sheds should at all times be well littercd.

The proper time to put hucks with ewes is the first of December, whieh is generally after they are arranged for winter, and that arrangcment should be made with reference to that object, allowing hut ono huck to a flock; and no wether shonld he allowed in a flock with a buck, as his presence creates suspicion, and disturbs the quiet so necessary to the desired perforinanco. The number of ewes to a buck will vary according to his age, vigor, and kecping; a full-grown, vigorous one, well fed, will scrvc one hnndred; tho same, without extra feed, will serve fifty; young ones from thirty to forty. Tho bucks should be painted on the hreast to makc apparcnt their progrcss. Four wceks is sufficicnt time for them to remain witlı the cwes; after that, there is danger of the ewes heing injured by their nngallant and knock-down Iropensities.

MEDICINES ENIPLOYED IN THE TREATMENT OF SIIEEP.-Simple medicines ought to be in the possession of the farmer for instant uso ill cascs 
of emcrgency; but the administration of the more potent drugs ought to be intrusted to the veterinary surgeon, by whom alone all important operations ought to be performed. Read's enema and stoniach-puinp adapted to sheep, slonld be in every breeder's hands, and kept eonstantly ready for use. In the treatmcut of many of the diseases of sheep, the advantages of purgative or of sedative injections are too much overlooked. Aperient injections inay consist of a handful of eommon salt, or an ounce or two ounees of Epsom salts, with a wineglassful of linseed oil, mixed in a pint of water or thin grucl. Sedative injections, in eases of diarrhea and dyscutcry, may consist of a pint of gruel or starch, with three or four grains of powdercd opium, or filty drops of laudanum.

Aperients.-In administering medieines to the sheep, the fluid should be allowed to trickle slowly and gently down the gullet or nesophagus, as we bave already urged in the case of the ox, and for the same reasons - the strueture of the stomach being in both animals on the same plan. To give medicine in a hurried manner, so as to force the animal to gulp it, is to defeat the very objeet intended; it will foree the pillars of the oesophagean eanal, enter the insensible pauneh, and there eontinue inert. It may here be as well to observe, that the doses of medieine for sheep, in general are about one-sixth in quantity of what are usually given to cattle. Young lambs require only. a third, or half the quantity of medicinc constituting a dose for an adult sheep.

The following medieincs are the most valuable apcrients:

Common Salt (Chloride of Sodium or Muriate of Soda). - Salt is a tonic in moderate doses, and of great benefit in the rot. It should always be aecessible to the floek. In doses of one or two ounces, dissolved iu four or six ounees of grucl, it forms an exeellent aperient.

Epsom Salts (Sulphate of Magnesia).- An exeellent purgative, and that which is most eommonly employed. Its dose ranges from half an ounco to two or three ounees. 'The repetition of small doses at intervals of six hours will keep up the action of the first full dose when desirable; or sulphur may be employed for this purpose.

Sulphur.-Sulphur, besides its value in cutaneous affections, is very uscful as an aperient, cspecially for kecping up the action of the bowels after the operation of salts. Dose, from one to tivo ounees. Sulphur is the base of every ointment for the cure of inange.

Aloes.-This drug is not only very uneertain in its operation in shcep, but lias often proved fatal, by indueing dircet inflammation. It is invaluable as a horse medicine, but should never be administered to the sheep.

linsced 0il.-Linseed oil is oceasionally used as a purgative; it is given in doses of two or three ounces.

ALTERATIVES AND SPECIFIC MEDICINES.-These arc medicines which exert a peculiar influenee on certain organs, altering their diseased action, or stimulating their respective secretions. Some act more especially on the ljver, others on the glandular systcm, and some on the skin; while one exerts a peculiar action on the museular fibers of the uterus. A knowledgc of the effects of these medicines has bcen gained by experience; but wo know nothing of their modus operandi. 
Calomel (Submariate or Protochloride of lifercury).-Calomel is seldom used in the treatment of the discascs of the shecp. In cascs of rot, two 6 three grains of calomel, mixed with a grain and a half of opium, have been found beneficial; this dose may be rcpcated evcry day, or every other day, for scveral times, its effects bcing watched.

Snlphate of Mlercury or Fthiops Mineral.-As an alterative medicinc, uscful in cutaneous disorders, Athiops mincral has long enjoyed grcat reputation; it is usually combined with nitre and sulphur in the following proportions for a daily dose: Aethiops mincral, one scruple; nitrc, two scruples ; sulphur, four scruples.

Iodine.-Iodine is uscful both as an external application, and also as a medicine taken internally, in cases of glandular affections and indurated swellings of the udder. Its most convenicnt form is the iodide of potassium. An excellent ointment is composed of onc part of the iodidc and seven of lard.

Iodide of potassium is strongly recommended in consumption, when tubereles liave formed on the lungs. The dose is two grains, gradually increased to fonr or six, given morning and evening, in a little gruel.

Ergot of Ryc.-In cases of lingering parturition, when the powers of the uteriss are exhausted, ergot of rye is found very uscful. It cxerts a peculiar action on that organ, and arouses its dormant cnergy. It should be employed with caution. The dose is a scruple or half a drachm, repeated at intervals of half an hour, if necessary. An infusion of ergot of ryc is used by lambers and shepherds, eonjoined witl a cordial composed of equal parts of brandy and spirits of nitre (sp: ather nitrici).

SEDATIVE AND FEBRIFUGE MEDICINES.-Tbese are medicines calculated to allay fever and moderate the action of the arterial system. Among these, nitre or nitrate of potass, tartar emetic, or tartrate of antimony, and the powder of digitalis, $i . e$, of the dried leaves of the foxglove, arc eljiefly in requisition. Opium, or tincture of opium (laudanum), is in a ccrtain scnse a sedative; indecd, in some discases, its usc ill allaying irritation cannot be overrated.

Nitrate of Potass, - Nitre is used as a febrifuge with good effect, but generally in combination with other medicines. Its dose is from half a drachin to a drachin.

Tartrate of Autimiony.-The effect of this medicine, in lowering t'e action of the heart and arterial system, is rery decided. Hence in many inflammatory diseases it is of great importanec. It is given to the sheep in doses of five or six grains.

Digitalis.-The powdered leaves of the dried foxglove have been long estcemed for their decided effects upon the action of the heart. They not only reduec the forec of the pulse, but often render it intermittent. Digitalis, in combination with nitre and tartar-cmetic or tartrate of antimony, forms an efficient fever medicine in eascs of high inflammation, as pleurisy and similar discases.

The following formula for sheep has becn used with suceess: digitalis powder, five grains; tartrate of antimony, five grains; nitrate of potass, lialf a drachm; water, threc or four ounces. Mix. To be given twico a day. 
ANTISPASMODICS.-The great antispasmodie, the great allayer of pain, and of irritation of the alimentary eanal, whether in eases of diarrhœa or dysentery, is opium.

Opium.-The dose of this all-potent medieine (when judieiously administered) is two or three grains. Combined with oil, it has been given in dysentery with the best effeets. Mr. D. Sayer found in eertain eases of dysentery the following preseription of great serviee:-linseed oil, two ounees; powdered opium, two grains. Mix in an infusion of linseed.

On the following day, he gave twiee in the twenty-four hours this mixture:-powdered opium, two grains; powdered ginger, and powdered gentian, of each, half a drachm. Mix in linseed tea.

Afterward this draught was repeated onee a day, with the addition of half an ounee of linseed oil. This was eontinued for tour days, when the sheep recovered. In eordial and astringent medieines, opium is an essential ingredient, and it may also be combined with aperients.

Laudanum, or Tincture of 0pium.-Tineture of opium possesses the same properties as the powder of opium, but is perhaps quieker in its effects. The dose for slieep is from twenty to sixty drops.

TONICS.-It is often neeessary in eases of debility, when acute diseases have been subdued, to restore or invigorate the system by tonies. Of these, gentian is the best, and, indeed, will supersede every other.

Gentian.-Powdered gentian root nay be given as a tonie in doses of from half a drachm to two drachms, in eombination with a seruple or half a draehm of powdered ginger in gruel or water, or in a little ale.

Cordials.-Cordials, or stimulating drenelses, are not so often given to sheep as to horned eattle. The best of these eordials are ginger, earaway-seeds, essenee of peppermint, and earbonate of ammonia.

Ginger.-The dose of this root in powder is from a seruple to a draehm. It is generally mixed with aperient medieines, and aids their operation.

Carnway-sceds. - Bruised earaway-seeds are useful as a cordial, though inferior to ginger. Dose, half a draehm or a drachm.

0il or Essence of Peppermint.-Peppermint water-that is, water in which the oil of peppermint is diffused-is a good vehiele for tonic and astringent medieines. It is never given alone.

Carbonate (Subcarbonate) of Ammonia. - In eases of repletion of the stomach by a mass of undigested eurd (to whieh lambs are subjeet), earbonate of ammonia may prove very useful, both from its stimulating and its antaeid properties. $\Lambda$ dreneh, eomposed of a seruple of earbonate of ammonia, two drachms of earbonate (sesqui-earbonate) of soda, half an ounee of Epsom salts, and a seruple of ginger, in warm water, may be given every six hours. $\Lambda$ solution of potash in lime-water is reeommended in these eases. We here give the direetions for making and administering this solution :-take a lump of quiek-lime, of the size of an egg, and pour on it, in a eonvenient vessel, as mueh water as will slake it. This being lone, then pour upon it one pint of boiling water; stir the whole up, and eover elose. While this is allowed to stand for some time, take an eight-ounee bottle, and put into it two ounees of subearbonate of potass, and fill up the bottle witl the line-water already made : pouring it off rather turbid than in a state of purity. Cork this up, and lahol it, "Solution of potass in lime-water." Of this "solution," 
a teaspoonful or two should be added to some warm water, together with half an ounee of salts and a seruple of ginger, and given every six hours, till good effeets result. We ean hardly eall this a eordial medieine. Its effects, setting aside the Epsom salts, are ehemieal, and the sane observation applies to ehloride of lime given internally in eases of hoove. Its dose in the shop is about half a drachm. As a disinfectant and eleanser of foul uleers, a solution of chloride of lime, applied externally, and used freely as a wash, is invaluable.

Chloride of Lime.-For its properties, see above. A solution of chloride of lime, for washing infected sheep-eotes, uleers, ete., may be made with half all ounee of powder dissolved in a gallon of water. Taken inter $\mathrm{ly}$ in hoove, it acts chemieally as a cordial by seeondary effects.

Carbonate (sesquicarbonate) of Soda,-Carbonate of soda is an antaeid, and useful as a component in eordial draughts, where the eorrection of acidity in the stomach is desirable. Dose, about a drachm.

ASTRINGENTS.-Astringents are medieines whieh aet upon the mueous membrane of the alimentary-canal, and eheek diarrhœa. They eonsist of lime, or ehalk, opium, eateehu, ete., and are always eombined with eordials. Of lime, or rather elaalk, little need be said; it is given in doses of either half a draehın or a draehm. Of opiun, we have already spoken.

Catechu.-This is an extract from a tree of the aeaeia tribe, and is very valuable. Dose, a seruple.

The following is a useful astringent eordial for sheep and ealves:prepared ehalk, one ounee; powdered eatechu, half an ounee; powdered ginger, two drachms ; powdered opium, half a drachm; mueilage or gumwater, thiek, two ounees; pepperinint-water, six ounees. Mix. Dose: two tablespoonfuls twiec a day.

Aluti.-Alum is not often used in the treatment of sheep. Its dose is ten or twenty grains, aceording to age. The "sleep's eordial" renders it nnneeessary.

EXTERNAL APPLICATIONS.- Setons are seldom used in the treatment of the diseases of sheep, and the wool prevents blisters from taking effeet. With respect to ehloride of lime, as we have notieed it under the head of eordials, we need not repeat our observations relative to its value as a disinfeetant and eleaner of foul, sloughing fetid uleers, when properly diluted with water (half an ounee to the gallon). The following external applieatious require a brief notice:-

Poultiecs.-Those of linseed-meal are best; it is often advantageous to mix with thein a little ehloride of lime, espeeially if they be applied to foul ulecrations. In aeeclerating suppuration, a little turpentine is a useful addition.

Stimulants.-Turpentine, eamphorated oil, and hartshorn, form a good embroeation, useful in strains and elironie rheumatisin. To two ounees of eamphorated oil may be added an ounee of turpentine, and half an ounee, or even an ounce of hartshorn.

0intments and Lotions, etc- - Mercurial Ointment, when rubbed down with five or seven parts of lard, forms a safe and almost eertain eure for the seab. White Lead is often sprinkled over the part struek by the fly, in order to destroy the maggots burrowing in the skin, It is superseded 
by the spirit of tar, or by the coarsest kind of fish-oil. Corrosive Sub. limate.-A dangerous remedy, often employed in solution as a wash for scab. Waslics, whether of a solution of arsenic, infusion of tobacco, or of hellebore, are equally objectionable. They are superseded by the diluted mercurial ointment. Spiril of Tur.-A useful application in foot-rot, and very serviceable when freely applied to parts that have been struck by the fly; it not only kills the maggots, but prevents the attacks of the insects, which are repelled by its odor. Turpentine.Useful as a stimulant in ointments and embrocations. It may be mixcd with linseed-meal poultices, in order to hasten the suppuration of sluggish tumors, and is a serviceable application to wounds of long standing which require a stimulus.

Dressings.-A mong the dressings for wounds, tincturc of aloes, tincture of myrrh, and tincture of benzoin, or Friar's Balsam, are chiefly in request. 'Tar mixed with lard is a nseful dressing in foot-rot.

Caustics. - At the head of caustics stands nitrate of silver, or lunar caustic. It is to the free nse of this that the vcterinary surgeon will trust in probing the wounds in eattle causcd by the bite of a rabid dog. It is very useful in removing warts and cutaneous excrescences. Other caustics, however, are in requisition. In eases of foot-rot, hydrochloric acid, or a solution of bichloride of mercury, is recommended by Mr. Read, as an application to the part affected. Butyr of antimony, or chloride of antimony, is a very useful and convenient canstic. It has been employed in foot-rot, and acts well where a superficial effect only is required. It does not producc any deep corrosion; henee in indolent ulcers, in foot-rot, and in the removal of fungous excrescences, it is of important service. Verdigris, or acctate of copper, mixcd with sugar of lead, finely powdcred, sprinkled on sluggish ulcer's, sonctimes aets with good effect. Blue vitriol, or sulphate of copper finely powdered, is frequently employed as an escharotic, in order to produce superficial sloughing. A saturated solution is recommended by some veterinarians as an application of great benefit in cases of foot-rot.

Fomentations.-The great benefit resulting from fomentations arises from the warmth of the water. In cases of inflamination of the udder or garget, fomentations are indispensablc. Many have an idea that the good cffeets of fomenting depend on the herbs which, as is generally the case, are boiled in the water; but this is an error. Poppy-heads or a little landanum in the watcr may be ad'antageous, from the known properties of opinm in allaying pain. Slight fomenting is nseless-it should be long kept up; but this is seldom done, for it requircs no small degree of quict patience.

Plaisters or Charges.-Plaisters, or eliarges, are in frequent demand. They are useful in cases of sprain or local debility, or as a covering and protection to sores or wounds, or the basal part of fractured horns. They form a good defense in case of travcl-worn feet, and in various ways are serviccable. They consist of a mixture of pitch, wax, resin, lard, etc., in different proportions, thickly spread upon coarse cloth or leathcr. Tar, spread upon cloth, forms an excellent plaister, especially where the main objeet is to cxclude the air. Their application requires some little dexterity of manipulation. Tar is a useful dressing in foot- 
rot, when the hcaling proeess has commenced. A plaister composed of a pound of piteh and two draehms of bees' wax, melted together, and spread while warm on soft leather or linen eloth, is applied with mueh advantage to the heads of sheep whieh are sore from the ravages of the maggots of the fly. Some, as a precautionary measure, smear the head in May with this composition, and scatter a little wool over it; others sew the plaister round tlie head.

Salving, or Smearing.-The practice of salving or anointing the skin of the sheep, after shearing, with some unctuous preparation, is not universal. It is, however, the ordinary eustom in Scotland, and is, indeed, cssential to the health and eomfort of sheep exposed to bleak winds in open mountain districts, to licavy mists, and drenehing and long-continued rains.

The primary object of smcaring is the proteetion of the skin from wet and eold ; and next, to promote the growth of the wool and improve its charaeter. Besides these objects, tliere are others not unimportantthe prevention of the attaeks of inseets, the destruction of such as might adhere to the skin, and the healthy aetion of the skin or the removal of cutancous affections, for which tar is very effieient. Tar, mixed with butter, in order to counteraet its tenaeity, is the ordinary salving material; and vast quantities of damaged butter are yearly sent to the grazing distriets of Scotland, for the use of the sheep farmers. One serious disadvantage, however, attends the application of tar-it indelibly stitine the wool ; hence it cannot be used for white goods, and what is morc, it will not takc the finer and more brilliant dyes. Wool thus tar-stained is termed laid wool, and sells at a lower ratio than white or unsalved wool. Yet in exposed situations the neeessity of salving is felt, and various unguents have been tried. Instead of butter whale-oil, as an adjunct to tar, has been used, and is recommended by the Hon. IV. J. Napier in bis "Treatisc on Iractical Store-farming;" but the tinge of the tar is not obviated by this adınixture. Mr. Mlogg says: "Of latc, several eompositions bave bcen purposely and extensively tried, in whieh the spirit of tar has been substituted for tar itself. This has, in some eases, been complained of as too irritating; and there is no doubt that a too free use of spirit of tar is injurious and even fatal. Some of the salves, whilc they prove to be perfectly well adapted to floeks that are elean, have been found ineffectual eitlier in euring or warding off the seab-a disease whieh the eommon salve made of tar and grease seems effectually to resist. When a floek is perfectly clcan, olive-oil lias been found to be the best substance for softening the flecee, and warding off rain and snow. For clean shcep, 'Taylor's salve' is also suitablc, though some English staplers liave condemned it. If a tar-salve were made so as to be free from the impurities of the tar, it might probably answer every purpose. The ordinary proportion of one cwt. of grcase to a barrel of tar, might be increased to one and a lialf ewt.; and when melted together, the impurities of the tar might be suffered to subside and be scparated. In this way the tar might not lcave a stain upon the wool when scoured. Olive oil seems to impregnatc the wool, or to adhere to it more firmly than any other kind of greasy matter; and it has been suecessfully employed by Mr. Sellar, of Morvich, a first-rate store-farmer in SutherInnd." 
Mr. Hogg recommends the following unguent to be rubbed over every part of the animal, after shearing, with a eurry brush:- -train or seal oil, four gallons; tar, half a gallon; oil of turpentinc, one pint. Mix. Mr. Jolnn Graham, of Ncwbigging, pereeiving the disadvantage of tar as a wool-stainer, and yet desirous of smcaring his sheep, used the following preparation, in which the tar was omitted, yellow resin being used in its stead :- butter, eighteen pounds; hogs' lard, eighteen pounds ; resin, twelve pounds; Gallipoli oil, one gallon. Mix. This quantity he found suffieient for fifty or fifty-five sheep, and the eost of smearing cach shcep was about four and a balf pence. He found this wool, when washed, equally valuable with the white wool : and it sold for a considerably higher price than the laid or tarred wool. The importanee of smearing or salving is undeniable. The use of a small quantity of some oleaginous or greasy application immediately after shearing is now generally acknowledged. The protection which it affords to the almost denuded skin-its substitution for the natural yolk, which is not in its full quantity immediately seereted-and the softness which it will impart to the wool-are eireumstanees well deserving attention. 
T H E

\section{DOMESTIC HOG:}

To

BREED, FEED, CUT UP, AND CURE. 


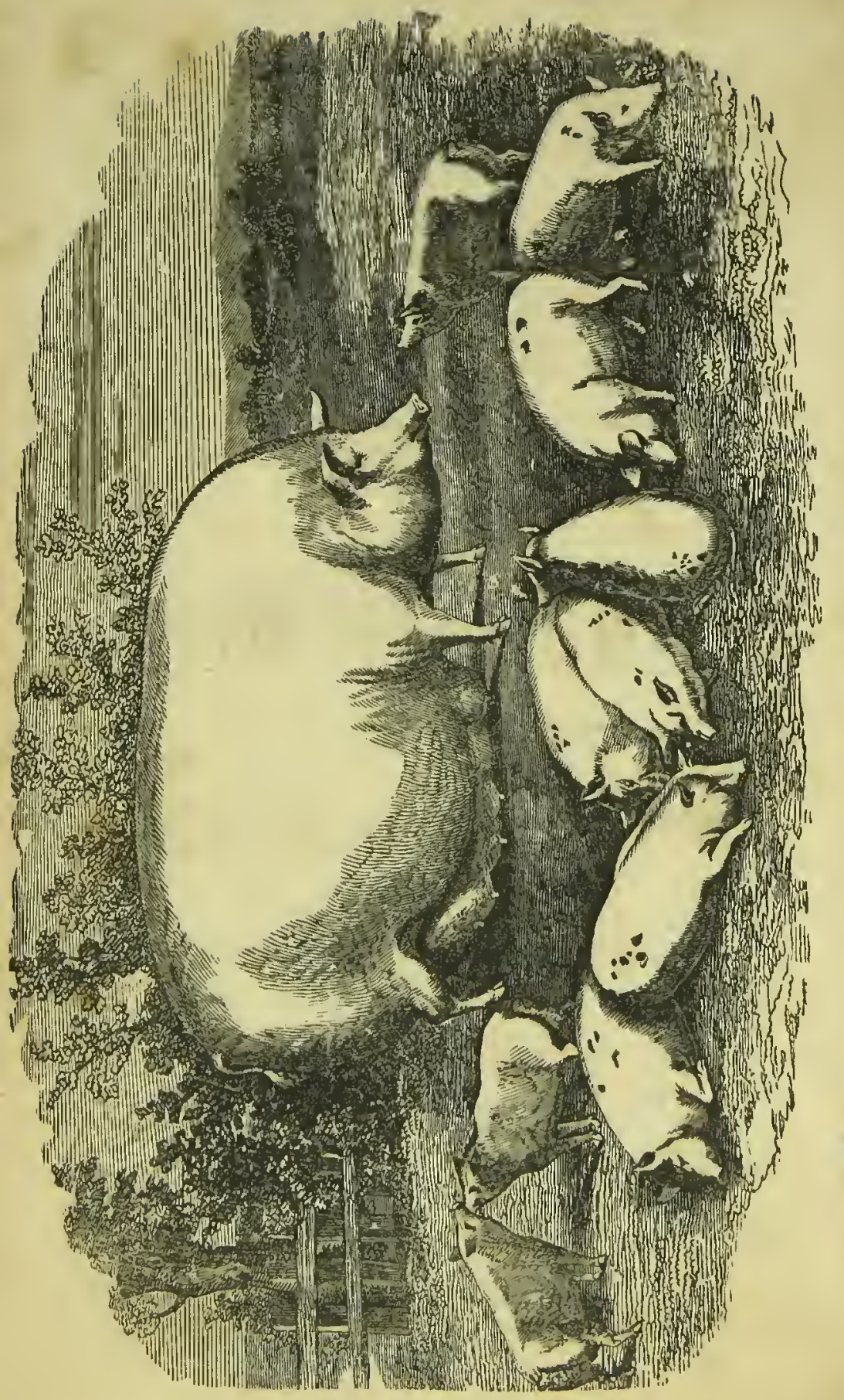




\section{THE DONIESTIC HOG:}

\section{TO BREED, FEED, CUT UP, AND CURE.}

VARIETIES OF TIIE HOG.-There exist only THREE actual varieties of the domestie hog - the 13erkshire, Chinese, and Highland, or Irish; all other breeds, deseribed as separate varieties, are only offshoots from one or the other of these three main stocks.

The Trne Berkshire Pig is black, or black and white, short-legged, full and round in the loins, rather fine in the laair, the ears small and ereet, and the snout not lengthy. This deseription of animal forms a striking contrast with the long-sided, convex-backed, lob-eared, long-legged, and shambling brute whieh was comınon in many parts of Great Britain, and almost universal in Ireland, thirty or forty years ago, and which still, without any improvement in form, is the general deseription of the pig thronghont Franee and most of Germany.

In giving preferenee, however, to the Berkshire breed, it is not to be understood that we consider them handsome in a positive sense, or perfeet models of good breeding and propriety in their habits and manners. No dunpy animal, with its belly near the ground, with four short erutches for legs, hair by no means silky, a little eurled tail, and small, sunk eyes, peering into every hole and corner and never looking upward to the glorious firmament, can be called an absolute beauty; but, compared with other raees of swine, the Berkshire are handsome; and, as to their habits and manners, they have no little merit; for, considering the natural dispositions of the hog family, and the contemptuons manner in which they are spoken of and treated everywhere (except in ecrtain parts of Ireland, and the Ilighlands of Scotland, where pigs are privileged orders, and experience such respect as to be permitted, and even invited, to oecupy the same room with their masters, by day and niglit, in eonsideration of their paying the housc-rent, and supplying the means of purehasing salt, eandles, and soap), the Berkshire raee have unquestionable merit, and appear to respeet the deceneies of life. Their females have never been known to eommit infanticide, as some other domesticated tribes of swine undoubtedly do, from what we consider a depraved taste; nor have either sex of this tribe been ever justly accused, or even suspected, of that cannibal propensity which has led individuals of ecrtain other tribes of the great log family to seize upon the tender babe in the cradle and devour it, "marrow, bones, and all!" 'They (the Berkshires) are so doeile and gentle that a little boy or girl may drive them to and from the pasture-ficld or the common without having their anthority disputed; and, when ranging about in the happy consciousness of liberty, thongh they may sometimes poke their noses where their interferenee is not desired, they do not perpetrate half the miselief to the turf which other elasses of swine are prone to commit.

- They seem disposed to content themselves with the grass on the surface of the soil, without uprooting it in search of delicacies that may lie 


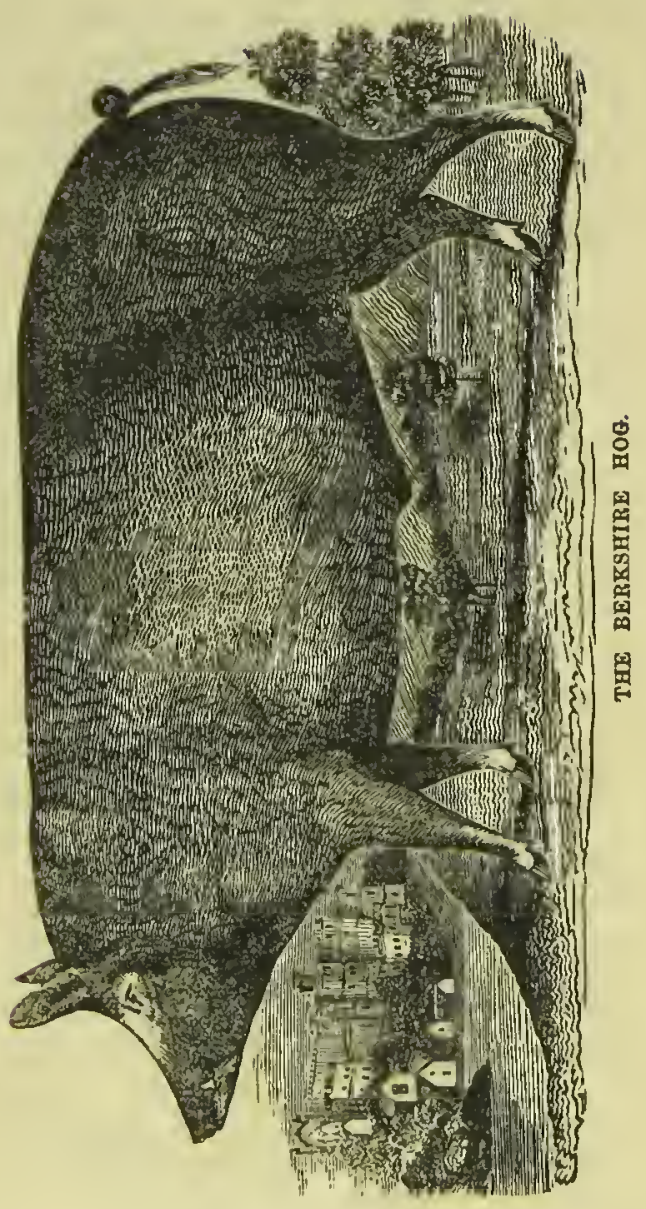


beneath, as do some of the long-snouted tribes which plow the earth up in furrows. They seem to make it a point of honor, too, to beeome fat as fast as possible, in return for the food they have received, in order that thus they may be in condition to pay "the pound of flesh" which is "in the bond" against them. They never fret at trifles, and thereby impede their digestion, and lose health and flesh. They never sulk and refuse their meals; nor do they eomplain of the quality or seantiness of their food, like some of those ungrateful elildren of eertain parochial asylums, who have faneied that they conld have eaten a little more porridge if it laad been ladled into the platter for them. I do not indeed say that the Berkshire swine are singularly neat in their personal habits, quite ceremonious at their meals, and free from the vice of gluttony, nor that they will not scramble and figlit for the best bits, and exhibit their unseemly manifestations of self-iudulgence; nor that they would be shoeked at snoring aloud, even in the presenee of royalty or nobility, if the inclination to fall asleep should seize them; but, then, it is to be remembered that every individual of the hog species would do the same things. In short, their peculiarities decidedly tend to the benefit of mankind; and, after all, their failings, like many of our own, proceed entirely from the stomach.

The eapacious pannch of the pig, and its great powers of digestion, are what render it so beneficial to us; jet, though in a domesticated state, a pig will eat almost any sort of animal or vegetable food-raw or cooked, fresh or putrid-he is, when at large, as naturalists inform us, the most delicate and discriminating of all quadrupeds. If free to select his vegetable food, he will reject a greater number of plants than the eow, the sheep, the horse, the ass, or the goat will refuse; so nice does he beeome when luxnries surround him, that in the orehards of peach-trees of North Ameriea, where the hog has delicious food, it is observed by Goldsnitl, " that it will reject the food that has lain but a few hours on the ground, and eontinue on the wateh whole hours together for a fresh windfall."

The Hampshire.-This breed is often eonfounded with the Berkshire, but its body is longer and its sides flatter; the head is long and the snout sharp. The eolor is usually dark-spotted, bnt sometimes altogether black, and sometimes white. This variety has been produced by crosses with the Berkshire, Suffolk, Chinese and Leicester breeds.

The Yorkshire.-This is the produet of a eross with the true Berkshire. They are quiek feeders and fatten rapidly.

IIerefordshire.-Generally supposed to be tho result of a eross with the Shropshire; it is shorter in the body, earries less bone than that breed, has also a lighter head, a smaller ear, a less rugged coat, and is altogether a far more valuable aninal. This hog is little inferior to the Berkshire breed.

Gloneestershire,-The Gloneestershire logs aro somewhat less in size than the preceding, and are also shorter in the body, rounder both in frame and limb, and altogether more compactly built. They mako good store hogs, and their pork is of prine quality.

Northamptonshire, of a light color, of a liandsome shape, light aud small ear, littlo bone, deep-sided and compactly formed. This is a profit- 
able porker and a good store, for he feeds well, fattens rapidly, and arrives early at maturity.

Norfolk, $-\Lambda$ small breed, with prieked ereet ears; color varions, but generally white. The white-eolored are said to be the best; when striated or blue, the breed is inferior, at least generally so. This is a short-bodied and eompaetly formed pig, and is an exeellent porker. There is another Norfolk variety, of larger size, spotted, but inferior in point of delieacy.

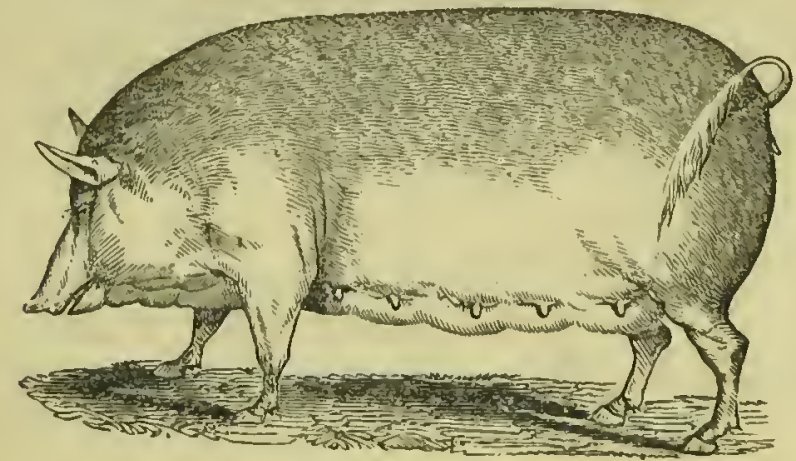

THE LFICESTER 80W.

Lcicestershire.-An ancient breeding district, and onee greatly eelebrated for its-swine. The old stock were large-sized, deep in the careass, and flat-sided; the head and ear light and bandsome, color lightspotted.

Lineolnshire.-The old Lineolnshire breed was light-eolored, or eren white, with, in most specimens, a eurly and woolly eoat, of medinm size; good foeders, eane early to matnrity, and fattened easily.

The Essex was in folmer days a very eapital hog, but degenerated, and, of eonrse, lost the esteem of breeder's. A recolleetion of the former good qualities which eharacterized the breed indueed some persons of practical judgment to revive it, which was aecordingly done; and now this hog, under the name of

The Improved Essex, ranks, most justly, very high amongst the British breeds of swine. The improvement of this hog is due to a eross with the Neapolitan; and this eross has been so frequently resorted to, that the pure Essex breed and the Neapolitan are so mueh alike that it is not every enrsory observer who is eapable of diseriminating between them. It is probable, also, that the Chinese was employed in the regeneration. 'The Essex lyog is up-eared; las a long, sharp head; also a long and level eareass, with small bone; eolor most frequently black, or black and white. This is a quieker feeder, but lie requires a greater proportion of food than the weight lie attains to justifies; besiles which, he is tronblesome in a fold, being restless ard diseontented. The pure breed should be almost basre of hair, and black in color.

There is another impror d assex breed ealled the Essex half-blacks, 
resembling that which we have deseribed, in eolor, said to be deseenderl from the Berkshire. This breed was originally introdueed by Lord Western, and obtained much eclebrity: "They are black and white, short-haired, fine-skinned, with smaller heads and cars than the Berkshire, feathered with inside hair, a distinetive mark of both; have short, snubby noses, very fine bone, broad and deep in the belly, full in the hind quarters, and light in the bone and offal. They feed remarkably quiek, grow fast, and are of an excellent quality of meat. The sows are good breclers, and bring litters of from eight to twelve, but they have the character of being bad nurses.

The Sussex.-Black and white in color, but not spotted, that is to say, these eolors are distributed in very large patches; one-half-say, for instanee, the fore-part of the body-white, and the hinder end black; sometimes both ends black, and the middle white, or the reverse. These are no way remarkable; they seldom feed over one hundred and sixty pounds.

The Chinese llog, - This breed is of small size, yet its carly maturity, the rapidity with which it takes on flesh, and the smallness of its bones, have indueed many breeders to use it in erosses with larger and coarser breeds-one of the best results of which has been the prodtetion of a very popular variety, denominated The Suffolk.

The siffolk llog. - The Suffolk breed of swine are a small, delicate pig, thin-skinmed, soft-liaired, small, prieked car; color white. They are in eharaeter like the Chinese, fed alınost as easily, are more hardy, and possess more lean meat.

IIOW TO CIIO0SE A PIG.-How to choose a pig?-that is the question. To rely on the terms Berkshire, Essex, Suffolk, Improved Yorkshire, Improved Bedfordshire, ete., as guarantees of first-rate qualities, would be folly. In all eountries, even those the most renowned for their breeds, there are both good and bad; and even of the best breeds some are inferior to the others, and ought to be rejeeted as unfit for becoming the parents of a lineage.

The following, the result of large and reent experience, are well worthy the attention of breerlers:

Ferility, - The strain from which the farmer or breeder selects ought to be noted for fertility. In a brecling sow this quality is essential, and it is one which is inherited. The same observation applies to other domestic animals. But, besides this, she slonld be a careful mother, and with a sufticient number of dings for a fiunily of twelve at a single litter. A young untried sow will generally display in her instinets those which have predominated in the race from which she has descended: and the number of teats ean be counted. Both boar and sow should be sound, healthy, and in fair but not orer-fat condition; and the former should be from a stock in whieh fertility is a eharacteristic.

Form,-It may be that the farmer has a breed which he wishes to perpetuate; it is highly inproved, and he sees no reason for immediato crossing. But, on the other hand, he may have an execllent breed with ecrtain defects - as too long in the limb, or too heary in the bone. Ilere, we should say, the sire to be chosen, whether of a pure or cross breed, should exhibit the opposite qualities, cren to an extreme, and be, withal, one of a strain noted for early and rapid fattening. 


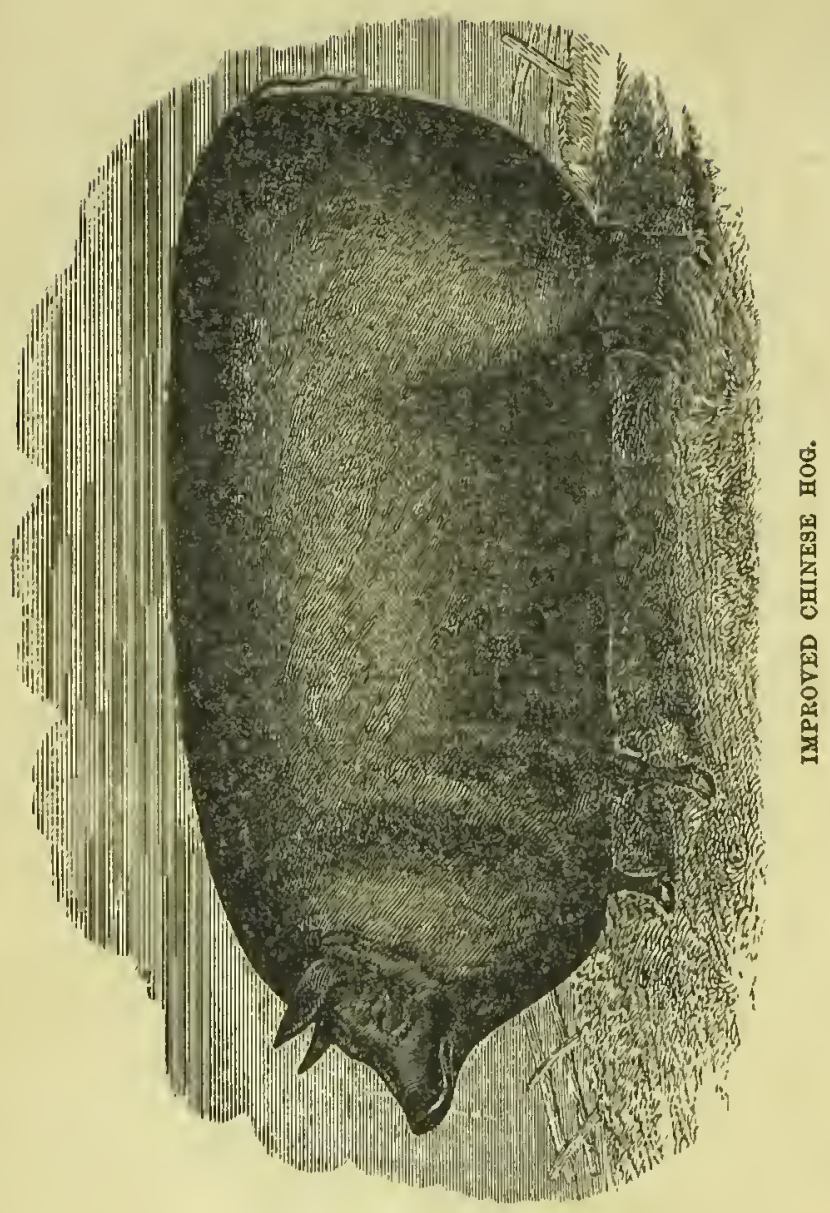


But what is meant by form, as applied to the pig? A development of those points eonneeted with the profit of the owner. In these points high or low blood is demonstrated. The head should be small, ligh at the forehead, sloort and sharp in the snout, with eyes aumated and lively, and thin, sharp, upright ears ; the jowl, or eheek, should be deep and full; the neek should be thiek and deep, areh graeefully fiom the baek of the head, and merge gradually into a broad breast; the shoulders shonld be set well apart at the elavieular joint; the body should be deep, round, well-barreled, with an ample ehest, broad loins, and a straight, flat, broad baek; the tail should be slender; the liams should be ronnd, full, and well developed; the limbs fine-boned, with elean, small joints; and with small, eompaet lioofs, set elosely together, with a straight bearing upon the ground. If in perfeet health, the animal will be lively, animated, hold up his head, and move freely and nimbly. We do not speak of fat hogs, for they are neeessarily sluggish and unwieldy; nor yet of pregnant sows; but of young store-hogs, or of young stoek seleeted for breeding.

The skin should be soft and thin, of a bright pink eolor; the neek short, the ehest wide (which denotes strength of eonstitution); broad, straight baek, short head, and fine snout, slightly eurved upward; and in the large breed there is often a pretty prominent swelling on the snout, between the nasal and frontal bones. The legs and hoofs shonld be small. The sows should have at least twelve teats. In purehasing a prize animal, whether boar or sow, see that it ean walk well. A lump of fat baeon may do to kill at Christmas, but will be of very little nse until redueed to breed from; and in the journey and reduetion you may lose your pig and your money.

For breeding sueking-pigs there is nothing better than the large English breed (they are prolifie, and good mothers), erossed with a white Chinese boar. No other breed will raise sueking-pigs to the same size as this eross; they also form exeellent porkers, speedily attaining from forty-eight to fifty-six pounds; but if required to be mueh larger, it will be found to pay better to treat them as stores, letting them graze, or run as "slioeks" in the field after liarrest, or rooting on the manureheap, until they are ten or twelve montlıs old, and then put them up to fatten. Still they are not so profitable as the improved Essex, and do not make sueh fine baeon as the improved Berkshire.

The inproved Essex, if well fed fiom the first, arrives very early at maturity, as to its frame or bony strueture, and is the best for making hobbledehoys of porkers from eighteen to twenty pounds' weight.

The improved Berkshire may be eonsidered the more useful to a farmer who desires a sort nseful in every stage of its growtl. The Berkshire sow will snekle ten or a dozen sueking-pigs-even more if assisted by artifieial means-and is very smperior for large ham and baeon. The small breed is very well for porkers, but not for the thiteh. A good little animal is good; but we want a good and big animal. The inproved Berkshire realizes this desideratum, as it realizes the lighest priee from the baeon-eurers, ents up wide over the baek, well interlarled with fat and lean. It is also more free from lameness than any other breed. 
In a word, in choosing a pig, you must consider your climate, your means of feeding, and your market; whether you want sueking-pigs or hobbledehoy pork.

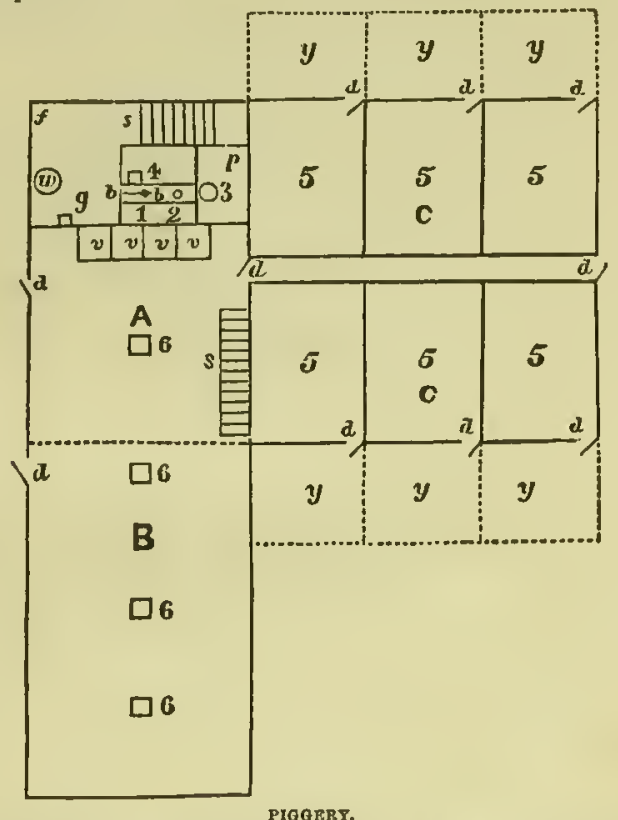

A, A, front: C, C, rear for pens: $5, \delta$, pens with alley between; $v, v, v, v$, vats on lcvel wlth pons; 1 , safety valve; 2 , steam pipo; 3 , supply barrol to holler; $b$, boller; $f$, furnace; $p$, platform partly over boller; 4 chimney; $t$, drain; 2 , water-clstern; $g$, door to collnr; $\theta$, stalrs; $d, d$, doors: 6,6 , scuttles to cellar; $y, y$, yards to pens.

IIOCSES AND PIGGERIES. $-\Lambda$ n inelosure proportionate to the number of swine whieh you intend to keep, and, if possible, so managed as to admit of extending the aeconmodation, will be found the best for general purposes. It shonld be provided witl a range of sheds, so situated as to be thoroughly sheltered from wind and weather, paved at tho bottom, and sloping ontward. Relative to the paramount necessity of cleanliness and dryness, let both inelosure and sheds possess the means of being kept so. In order to keep the sheds, whieh are designed as sleeping places, in a dry and elean state, an inelination outward is neeessary; a shallow drain should run along the whole of their extent, in order to reeeive whatever wet flows down the inelined plane of the sleeping huts; and provision should also be made for this drain to earry off all offensive matters beyond the preeinets of the piggery.

The ground on which the piggery is established should likewise be divided into two parts, by a drain, which should run through it; and toward this drain each seetion should slope. This the main drain should be earried beyond the folcl, and fall into a large tank or pit formed for that purpose. The object in view is to keep the pig-fold and sties in 
a elean and dry state, and to preserve the valuable liquid manure, which comes from the animals you keep. Some will probably inquire whether it would not be better to suffer the moisture to soak into earth or straw, or other substanees on the floor of the inclosure, and then to elear all away periodically, than to drain off the liquid into a tank. By drawing off the liquid you add to the eleanliness of your swine, and, in proportion, to their health and eapaeity for thriving; and the eollection of the liquid manure into tanks is less tronblesome than the removal of substanees saturated with it, from the floor of the fold, would be.

The sties sliould be so eonstructed as to admit of being elosed up altogether, when desirable; for swine, even the hardiest breeds, are susecptible of cold, and if exposed to it in severe weather, it will materially retard their fattening. The sty shonld be kept eonstantly supplied with elean straw. The refuse earted into the tank will, in the form of manure, more than repay the value of the straw. It has been asserted that swine do not thrive if kept upon the same ground in eonsiderable numbers; this assertion rests on a want of ventilation and clcanliness.

As to troughs, let them be of stone or cast metal; - if of wood, the pigs will soon gnaw them to pieces;-and let them be kept clcan. Before each feeding, a pail of water should be dashed into the trough; this may be decmed troublesome, but it will confer golden returns on those who attend to it.

A supply of fresh water is essential to the well-being of swine, and should be freely furnished. Some recommend this to be effected by having a stream brought through the piggery; and undoubtedly, when this ean be managed, it answers better than any thing else. Swine are dirty feeders, and dirty drinkers, usually plunging their fore-fect into the trough or pail, and thus polluting with mud and dirt whatever may be given to them. Onc of the advantages, thereforc, derivable from the stream of ruming water being brought through the fold is, its being, by its running, kept constantly elean and wholesome. If, thercfore, you are unable to proeure this advantage, it will be desirable to present water in vessels of a size to reecive but one head at a time, and of such height as to render it impossible or diffieult for the drinker to get his feet into it. The water should be renewed twiee daily.

We have hitherto been describing a piggery eapable of containing a large number; a greater proportional profit will be realized by keeping a number of swine than a few. It may happen, however, that want of capital, or of inclination to embark in swinc-fceding as an actual speeulation, may induee many to prefer keeping a small number of pigs, or even perhaps one or two, in which case such accommodations as have been deseribed would be more than superfluous. In this case, a single hut, well sheltered from wind and rain, and built with a due regard to comfort, to warmth, with a little court surrounding its door, in which the tenant may feed, obey the ealls of nature, and disport limself, or bask in the sunshine, will be found to answer; a small stone trough, or a wooden one, bound with iron, to preserve it from beirg gnawed to pieces, will complete the necessary fumiture. The trough will serve alternately for food and drink. Even, however, when this limited aecommodation is resorted to, a strict attention to cleanliness is no less 
necessary than when operations are earried on on the most extensive seale. Both the floor of the hut and that of the little eourt should be paved, and should ineline ontward; along the lowest side should be a drain, with a suftieient declination, and so contrived as to communieate with your dung-tank. The farther the manure-heap, or tank, from the dwelling, the better: vegetable matter, in progress of deeomposition, gives rise to pestilential vapors, or miasmata.

When the weather is fine, a few hours' liberty will serve the health and the eondition of your hog, and a little grazing would be all the better. Should you be desirous of breeding, and keep a sow for that purpose, you must, if you have a seeond hog, provide a second sty, for the sow will require a separate apartment when lieavy in pig, and when giving suek. This may be easily effeeted by building it against that which you have already ereeted, thus saving the trouble of raising nore walls than are absolutely neeessary; and it need not have a eourt attached to it, should it be ineonvenient for you to lave one, as the best aeeommodation ean be given up to the breeding sow, and your pigs will do well enough with a single apartment, if not too eonfined, and it have suffieient ventilation; and if you permit them the advantage of taking air for a few hours daily. The extensive feeder should have a boiler of large size, properly fitted up, and an apparatus for steaming, as some vegetables are eooked in this mode more advantageously than by boiling. The poor man ean use a pot as a substitute for a boiler, remembering in every ease to elean it before using. Food should be presented to swine in a warm state-neither too hot nor too eold.

A sty should be about seven or eight feet square, and the eourt about ten feet. The seeond sty need not be more than six feet square, and does not absolutely require a eourt.

Breeding, Rearing, and Feeding.-In the seleetion of a boar and sow for breeding, mueh inore attention and eonsideration are neeessary than people generally imagine. It is as easy, with a very little judgment and management, to proeure a good as an inferior breed; and the former is infinitely more remunerative, in proportion to outlay, than the latter ean possibly ever be. In seleeting the parents of your future stoek, you must bear in mind the preeise objeets you may have in view, whether the rearing for pork, or baeon; and whether you desire to meet the earliest market, and thus realize a eertain profit, with the least possible outlay of money, or loss of time; or whether you mean to be eontented to await a heavier although somewhat protracted return. If baeon, and the late market be your objeet, rou will do well to seleet the large and heavy varieties, taking eare that the breed has the eharacter of being possessed of those qualities most likely to insure a heavy return, viz.: growth and facility of taking fat, relatively possessed by eael. To that deseription we refer the reader. If his objeet be to produee pork, he will find his aeeount in the smaller varieties; such as arrive witl greatest rapidity at maturity, and whieh are likely to produee the most delieate flesh. In produeing pork, it is not desirable that it should be too fat, without a eorresponding proportion of lean; and on this aecount, rather take a eross-bred sow than a pure Chinese stoek, from which the over-fattening results might most naturally be apprehended. The Berkshire, erossed 
with Chinese, is about the best porker I can mention. In every case, whetlier your object be pork or bacon, the points to be looked for arein the sow, a small, hively bead, a broad and deep chest, round ribs, eapacious barrel, a haunch falling almost to the hough, dcep and broad loin, ample hips, and considerable length of body in proportion to height. One qualifieation should crer be kept in view, and, pcrhaps, should be the first point to which the attention should be directed, viz., smallness of bone.

Let the boar be less in size than the sow, shorter and more compaet in form, with a raised and brawny neek, lively eye, small head, firm, hard flesh, and his neck well furluished with bristles-in other respects seek the same points we lave described in reference to the sow. Breeding within too elose degrees of eonsanguinity, or, breeding in and in, is caleulated to produce degeneracy in sizc, and also to impair fertility; it is thereforc to be avoided, although some brecders maintain that a first cross does no harm, but on the eontrary, that it procluces offspring which are disposed to arrive earlier at maturity. This may in some instances be the case; it is so with horned cattle, but as far as swine are conecrned, it is not my own cxperience.

Differences of opinion cxist as to the preeise age of boar and sow, at which breeding is nost advisable. They will, if permitted, breed at the early agc of six or seven inonths; but this is a practiec not to be reeommendecl. My adviec is, to let the sow be at least one year old, and the boar at least eighteen months; but, if the former has attained her seeond year, and the latter his third, a vigorous and numerous offspring are more likely to result. The boar and sow retain their ability to breed for alout five ycars, that is, until the former is upward of eight years old, and the latter seven. I do not reeommend using a boar after he has passed his fifth year, nor a sow after she has passed her fourth, unless she has proved a peculiarly valuable breeder; in which casc, she might be suffered to prodnee two or three more litters. When you are done with the services of the boar, have him emasculated-an operation that can be performed with perfect safety at any age-fatten or sell him. When it is no longer desirable to brecd from the sow, kill her. Before doing so, it is a good plan to put her to the boar, as she takes fat afterward more rapidly than she otherwise would.

If a sow be of a stoek eharacterized by an unnsual tendency to take fat, it is well to breed from her at an unusually early age-say eight or nine months; for this tendeney to fat, in a breeding sow, is highly objectionable, as conducing to danger in parturition. Let her have the boar a eouple of days after pigging, and let her breed as fiequently as she is eapablc of doing. 'This will cffectually check the tendency to fat; and, after having taken a few litters from her, you will find the rapidity with which, should you desirc her for the buteher, she will take flcsh quite extraordinary. In the case of such a sow, do not give the boar before putting her up to fatten.

Feed the breeding boar well; keep him in high eondition, but not fat; the sow, on the other hand, should be kept somewhat low, until aftcr conception, when the quantity and quality of her food should be gradually inereased. The best times for breeding swine are, the month. 
of Mareh, and July or Augnst. A litter obtained later than August bas much to contend with, and seldom proves profitable; some, indeed, state that when such an occurrence does take place, whether from accident or neglect, the litter is not worth keeping. It is little use, however, to throw any thing away. Should the reader at any time have a late litter, let him leave them with the sow; feed both her and them with warm and stimulating food, and he will thus have excellent pork, with which to meet tbe market, wben that article is at once scarce and dear, and consequently profitable. By folloying this system of management, he will not only turn his late litter to account, but actually realize unost as good a profit as if it bad been produced at a favorable season.

The period of gestation in the sow varies; the most nsual period during which she earries her young, is four lunar months, or sixtecn weeks, or abont one hundred and thirteen days. M. 'Teissieur, of Paris, a gentleman who paid mucb attention to this subject, in connection not merely with swine, but other animals, states that it varies from one bundred and nine to one hundred and forty-three days; lie formed bis ealculation from the attentive observation of twenty-five sows.

The sow produces from eight to thirteen young ones at a litter, sometimes even more. Extraordinary fecundity, is, liowerer, not desirable, for a sow cannot give nourishment to more young than she has teats for, and, as the number of teats is twelve, when a thirteenth one is littered, he does not fare very well. The sufferer on these occasions is of course tbe smallest and weakest; a too numerons litter aro all indeed generally undersized and weakly, and seldom or never prove profitable; a litter not execeding ten, will, usually, be found to turn out most advantageously. On account of the discrepancy subsisting between the number farrowed by different sows, it is a good plan, if it can be managed, to have more than one breeding at the same time, in order that you may equalize the number to be suekled by each. The sow seldom recognizes the presence of a strange little one, if it has been introduced among the other's during her absenee, and has lain for half an hour or so among her own offspring in their sty.

While the sow is earrying her young, feed her abundantly, and increase the quantity until parturition approaches within a week or so, when it is as well to diminish both tbe quantity and quality. While she gives suek you cannot feed her too well. You may wean the young at eight weeks old, and should remove them for that purpose from the sow; feed them well, frequently, abundantly, but not to leaving, and on moist, nutritious food, and pay particular attention to their lodgmenta warm, dry, comfortable bed is of fully as mucl conseqnenee as feeding, if not even of more. Should the sow exhibit any tendeney to devour its young, or should she have done so on a former occasion, strap up her mouth for the first three or four days, only releasing it to admit of her taking her meals. Some sows are apt to lie upon, and crush their young. This may be best avoided by not keeping the sow too fat or heavy, and by not leaving too many young upon her. Let the straw forming the bed also be short, and not in too great quantity, lest tbe pigs get huddled up under it, and the sow uneonseionsly overlio them in that condition. 
The young pigs should be gradually féd before permanently weaning them; and for first food, nothing is so good as milk, which may be sueeeeded by ordinary dairy wash, thiekened with oat or barley-meal, or fine pollard; this is better scalded, or, better still, boiled. To the sow, some dry food should be given onee daily, which might eonsist of pease, beans, Swedish tmrnips, earrots, parsnips, or the like, either well boiled or raw; but I prefer the food to be alucays boiled, or, what is stil! better, steamed. Sone wean the pigs within a few hours after birth, and turn the sow at onee to the boar. Under eertain eireumstanees, this may be found advantageous; but I think that the best mode of management is to turn the boar into the log-yard about a week after parturition, at whieh time it is proper to remore the sows for a few hours daily from their young, and let them aeeept his overtures when they please. It docs not injnre either the sow or her young if she take the boar while suekling, but some sows will not do so until the drying of their inilk.

Castration and Spaying should only be performed on sueb as you in. tend to keep, as you do not know what a purebaser's wishes on the subjeet night be. It is, of eourse, unneeessary for ine to give any direetions as to the mode of performing this operation, as no amateur should attempt it; and men who make the praetiee their means of livelihood are, in every distriet, not diffieult to be got at, or exorbitant in their terms. The sow is, if desirable, to be spayed while snekling; the boar, as we have already stated, may be eastrated at any age with perfeet safety.

Ringing.-At weaning time, ring the young pigs. This operation mnst be a painful one, but searcely so nueh so as the little sufferers would seem to indicate. Ringing is, however, absolutely neeessary, unless the eartilage of the nose be cut away, a praetiee resorted to in substitution for it in sone parts of England; the latter praetiee is, however, far inore ernel than ringing, and its effieaey is by many stated to be at the best questionable.

After about fire weeks' high and eareful feeding subsequent to weaning, the young pigs nay be put up for stores, porkers, ete., aeeording to Four views respecting them. Very young pigs, immediately after being weancel, if fed on the refuse of a dairy, will be brought up for delieious pork in five or six weeks; for the last week prior to killing, the addition of grains or bruised eorn will impart a degree of firmness to the flesh, that is considered an improvement. This is ealled "dairy-fed pork," and it never fails to feteh an enhaneed priee, thereby amply remunerating its produeer.

Hogs designed for pork should not be fattened to the same extent as those designed for bacon. We are aware that it will be vain for us to request the reader not to do so, as fat produees weight-weight, profit -and profit is the objeet of the feeder. But to those who feed for home eonsumption, we urge the suggestion, and they will find their aeeount in following it. l'orkers should be suffered to run at large. Grazing, or the run of a wood in whieh roots or nuts may be met witl, is ealeulated in an eminent degree to inprove the quality of their flesh. It will be neeessary to give tho hoge regular meals, independent of what 
they can thus cater for themselves; and the hours for so doing should be in the morning, before they are let out, and in the evening, before they are returned to the sty. Too many swine should not be kept in onc sty; and if one become an object of persecution to the rest, lie should be withdrawn. The introduction of strangers should likewise be avoided. Bacon hogs fatten best by themselves; they need no liberty; and it is only necessary to keep the sty dry and clean, and to fecd abundantly, in order to prepare them for the knife. In order to fatten a hog, his comforts must in every respect be attended to.

Those who make pork-feeding a business, and consequently keep a number of these animals, should so manage as to be cnabled to provide for their maintenance and fattening from the produce of their crops. They should thcrefore raisc the potato, beans, pease, barley, buckwheat, flax, parsnips, carrots, cabbage, lettuce, Lucerne, Italian rye-grass, clover, rape, chiccory, and vetches. Nor are we to forget the important articles, inangold and Swedish turnips; the latter especially, as being an article that sad necessity has recently, for the first time, brouglit into the full degrce of notice it has al ways deserved; and an article that is now found to be no less valuable for human food than it is admitted to be for the food of cattlc.

The best possible mode of feeding hogs is witl a mixture of two or more of the roots or plants enumerated, well steamed, and a little meal or bran added, or, instead of meal or bran, add brewer's grains, wash, half-malted barley, pollard, ctc. Let these be well boiled and given moderately cool, and in a moist state.

The advantages derivable from the use of hay-tea in store-feeding hogs was, I think, for the first time demonstrated to the public, some ycars ago, by Mr. Saunders, of Stroud, in Gloucestcrshire. Mr. Saunders was induced to try this diet with hogs, from an observation of its efficacy in weaning calves; his cxpcriments wcre attended with the most unqualjfied success.

The usc of flax-seed, as an addition to the other food for fattening swine, has been recommended, but is found not to answer nearly so well in the crude state as previously kiln-dried, and well crushed, so as to crack the secd; othcrwise the animal will pass a large proportion of the seed in a whole state; the whole seed acts as a purgative and diuretic, which will be opposcd to the secretion of fat. To prepare the secd for food, steep them for twelve hours in water, which may be poured on them in a tepid state, but not at boiling heat; and, prior to giving the mess, add as much lukewarm wash as will bring it to the consistence of gruel. This wash may be produced from brewers' grains, or simply from mangold or Swedish turnips, well boiled and mashed, and given with the water in which they have been boiled; the addition of a proportion of bran improves the mess, and, when onc has it, it should not be omitted.

The adoption of hay-tea as the vehicle for mixing these ingredients, will be found also advantageous. Do not boil the flax-seed-boiling will produce a coarse, tough, and not very digcstible mass; but stceping, on the contrary, furnishics a rich and nutritious jelly. Linseed cake is a good substitute for the sced, and is to be given in a proportion of 
fourteen pounds for seventeen or eightecn pounds of ground seed. Neither should he given, except in comhination with a large proportion of other substances, as they are of a very greasy nature, and are apt to impart a rank flavor to flesh, if given in an unmixed state, and are actually more efficacious in comhination. If you have plenty of mcal, the addition of a little to the daily feeds will be found to tell well, especially toward the close of fattening, a few weeks previous to transferring your stock to the hutcher.

The refuse of mills forms a very valuable item in swine food, when mixed with such hoiled roots as I have enımerated-as starch sounds, the refuse from the manufacture of that article; also the fihrous refuse remaining from the manufacture of potato-starch.

Swine are frequently kept hy butchers, and are fed principally upon the garhage of the shamhles-as entrails, the paunches, lights, and the viscera of sheep and cattle, as well as the hlood. Swine are, like their human owners, omnivorous, and few articles come amiss to them. It must, nevertlieless, be confessed, that the flesh of hogs fed on animal food is rank hoth in smell and taste, and readily distinguishahle from that produced from a vegetahle diet. I am not unnecessarily prejudiced, and it is on the merits of the casc alone that I condemn butcher-fed pork. Pork hutchers, resident in large towns, are very apt to feed chiefly on offal of all sorts, including that arising from the hogs daily slain and dressed for the market.

There is yct another description of feeding-I allude to the feeding of swine in knackers' yards. The animals are kept in considerable numhers, and are fed wholly upon the refuse of dead horses-chiefly the entrails, the carcass heing in too great demand among those who keep dogs to permit of it heing unnecessarily wasted. Nor are these horses always fresh, the swine reveling in corruption, and disputing with the maggot the possession of a mass of liquid putrefaction. And are we to say nothing of the number of horses who die of glanders, farcy, or some similarly frightful contagious and incurable disorder? How can we he certain that this is not one of the many sumrces whence occasionally spring apparently canseless pestilences or malignant epidemics? While such a practicc is tolerated, with what cantion should we not purchase bacon or pork, lest we should thus eat at second-liand of substances so revolting to the feelings, so dangerous to individual and puhlic health !

Chandlers? Greaves are likewise ohjectionable as food for swine, unless given in comparatively small quantities, and mixed with hran, mcal, and hoiled roots. If fed wholly on either greaves, or oil-cake, or flax-seed, the flesh hecomes loose, unsuhstantial, and carriony; and gives out a flavor resembling that of rancid oil.

Ilogs that have heen fed chietly on corn, alternated with the vegetahle diet already described, produce pork nearly equal in delicacy of flavor, whiteness of color, and consequènt value, to that well-kuown, delicious article, DAIRY PORK. Indian corn is most useful in feeding and in fattening pigs; it should he employed in conjunction with oat or barley meal, or some other equally nutritious matter.

Respecting the quality of food, vast numbers of bacon hogs are almost invariably fed upon potatoes; but however apparently satisfactory may 
be their weight and eondition, yet, when slaughtered immediately, or before liaving several weeks of substantial food, to barden their flesh, they are always found inferior to eorn-fed pork and baeon, the fat laving a tallowy appearanee, of an insipid taste, and shrinking for want of firmness; whereas, when boiled, it shonld be transparently hard, with a tinge of pink in its eolor; the flavor should be good, and the meat should swell in the pot. Potatoes, therefore, though fine food for stores, should never be used alone as sustenanee in the fatting of bacon hogs; for, in proportion to the quantity employed, it will render the flesh and eonsequently the priee, inferior to that of hogs which lave been properly fed. They are, however, frequently employed, when steamed, in eonjunetiou witl either tail or stained barley, eoarsely ground; and farmers who grow. potatoes for the market may thus profitably dispose of the ehats along with their unmarketable eorn; but those persons who wish to aequire a reputation for prodneing fine baeon, should never use any thing for fatting but hard meat, together with skim-milk, if it ean be proeured.

When swine are not of very large size, and it is desirable to raise pork rather than baeon, a very economieal mode of feeding may be advantageously employed :-it eonsists of equal parts of boiled Swedish turnips or potatoes, and bran. If it be desirable to render the aeeumnlation of fat more rapid, let Indian meal be substituted for the bran, and in flax-growing eountries, the seed prepared as already direeted.

A hog washed weekly with soap and a brush will be found to thrive, and put up flesh in a ratio of at least fivo to three, in eomparison to a pig not so treated. This faet has been well tried, there ean be no possible question about its eorreetness, and the duty is not a very diffieult matter to perform, for the swine, as soon as they diseover the real eharaeter of the operation, are far from being disposed to objeet, and after a eonple of washings, submit with the best graee imaginable.

BEWARE Not to Surfent your logs. It is quite possible to give too mueh even to them, and to produee disease by over-feeding.

Many examples of great weights, produeed by judieions feeding and management, are upon reeord. NIr. Croekford's Suffolk hog, at two years old, weighed nine liundred and eighty pounds; but I seareely think it eould have been true Snffolk, that being a small breed. Mr. Ivory's Shropshire hog weighed fourteen hundred, when killed and dressed, and there was, a sliort time sinee, a speeimen of the improved Irish breed of hog exhibited in Dublin, at the Portobello Gardens, whieh weighed upward of twelve hundred weight; this, when killed, would have amounted to something over half a ton,

In eonelusion, observe eaution in eonjunetion with the direetions already given relative to feeding.

1. AvoID Foul FEEDING.

2. Do NOT OMIT ADDING SALT in moderate quantities to the mess given; you will find your aceount in attending to this.

3. Jied at regular intervals.

4. Cleanse the trovghis irevious to feeding.

5. Do NOT OVER-FEED; give only as mueh as will be eonsumed at the meal. 
6. VARY yOUR BLLL of FARE. Variety will ereate, or, at all events, increase appetite, and it is further most conducive to health; let your variations be guided by the state of the dung east; this should be of medium consistence, and of a grayish-brown color; if hard, increase the quantity of bran and succulent roots; if too liquid, diminish, or dispense with bran, and let the mess be firmer; if you ean, add a portion of eorn-that which is injured, and thus rendered uufit for other purposes, will be found to answer well.

7. FEED YOUR STOCK SEPARATELY, in elasses, aecording to their relative conditions; keep sows in young by themselves; stores by themselves; and bacon hogs and porker's by themselves. It is not advisable to keep your stores too high in flesh, for high feeding is calculated to retard development of form and bulk. It is better to feed pigs intended to be put up for bacon, loosely, and not too abundantly, until they have attained their full stature; you ean then bring them into the highest possible condition in an ineonceivably short space of time.

8. Do NOT REGRET THE LOSS OR SCARCITY OF POTATOES, so far as swine-feeding is concerned. Its loss has been the means of stimulating inquiry and producing experiment, which has resulted in the diseorery that many other superior vegetables have been litherto negleeted and foolishly passed aside.

9. DO NOT NEGLECT TO KEEP YOUR SWINE CLEAN, DRY, AND WARM. These are essentials, and not a whit less imperative than feeding, for an inferior description of food will, by their aid, sueceed far better than the highest feeding will without them; and we would reiterate the benefit derivable from washing your logs; this will repay yonr trouble manifold.

10. WATCh the Markets. Sell when you sce a reasonable profit before you. Many and many a man has swamped himself by giving way to covetousness, and by desiring to realize an unusual amount of gain ; reeolleet how very fluctuating are the markets, and that a certain gain is far better than the risk of loss.

Time Requisite for Fecding Fat-quantity of Food.-This will, of eoursc, vary very considerably, according to the weight, age, breed, and condition of the store when first put up, as well as the deseription of foorl ou which, up to that period, the animal has been fed. The same observations are applieable to the quantity of food required for the production of fat.

If a young store, five or six weels may be suffieient; if older, six or eight; and if of the mature age, intended for a perfect bacon hog, of that moderate degree of size and fatness which is preferred for the general eonsumption of the middle classes, from twelve to fourteen. A bacon hog, if intended to be thoronghly fattened for farm use, should, however, be of a large breed, and brought to such a state as not to be able to rise without difficulty, and will, perhaps, require five or six months, or even more, to bring him to that eondition. This, however, silpposes him to be completely fat; to ascertain which with perfect accuracy, he ought to be weighed every week during the latter part of the proeess; for although his appetite will gradually fall off as he inereases in fat, yet the flesh which he will aequire will also diminish, 
until at last it will not pay for his food, and he should then be inmediately slaughtered.

The Chemestry of Pig-Fceding.-In 1851-2, with the view of ascertaining, among other points, the eomparative valuc of various kinds of food used for fattening pigs, Mr. J. B. Lawes, of Rothansted, Herts, the eminent ehenist and manufaeturer of super-phosphate of limc, undertook a series of experiments on a large scale, reeorded in a paper illustratcd by a series of elaborate tables, whieh oeeupy upwards of eighty pages of the fourteenth volnme of the "Journal of the Royal Agrictiltural Soeiety." This paper, of the highest possible value to the scientific agrieulturist, few plain farmers or fancy pig-feeders wonld have the courage to read, or would be able fully to understand, if they did. We shall, therefore, endeavor to give the results briefly and plainly; they fully confirm the opinions of the most successful pig-feeders.

The food employed in these experiments was eomposed as follows:1. Equal weiglits of benns and lentils; 2. Indian corn; 3. Bran. The food was aeeurately weighed; and the animals werc put into the scalcs every fourteen days.

For the first series of expcriments, forty animals, as ncarly as possible of the same eharaeter, and age about ten months, werc pnrehased, and divided into twelve pens of three pigs each, and werc all fed alike for twelve days, ehanged from pen to pen, and the unruly ones whipped, so as to put down the tyrants and enablc them all to start fair in the feeding race for weight. When fairly started, twelve dietaries were prepared fiom three standard food-stuffs, arranged as follows:-1. Bean and lentil mixture, an unlimited allowance; 2. Two pounds of Indian corn per pig per day, and an mnlimited allowance of the beans and lentils; 3. Two pounds of bran per pig per day, and beans and lentils unlimited; 4. Two pounds of Indian corn, two pounds of bran, and the bean and lentil mixturc unlimited; 5 . Indian coru alone, unlimited; 6. Two pounds of beans and lentils, and unlimited Indian corn allowance; 7. Two pounds of bran per day, and unlinited Indian corn allowance; 8. 'Two pounds of bean and lentil mixture, two pounds of bran, and Indian corn unlinitcd; 9. Two pounds of bean and lentil mixture, and bran unlimited; 10 . Two pounds of Indian corn-meal, and bran unlimited; 11 . Two pounds of bean and lentil mixture, two pounds of Indian corn, and bran unlimited; 12. Bean and leutil mixture, Indian corn-meal and bran, each scparately and unlimitcd.

This food was duly mixed with water. Thc animals were fed three times a day; viz, early in the morning, at noon, and at five o'cloek in the evening. The limited food was mixed with a small quantity of that given ad libilum in the first two fceds of the day. Great care was taken in the management of the supply of food, both that the troughs slould gencrally be eleared out before fresl food was put into them, and that the pigs shonld always have a liberal supply within their reacl..

In one of the pens two of the pigs having become unwell from large swellings in their nceks, whieh affected their breathing, a mixture was prepared, consisting of twenty pounds of finely-sifted coal-ashes, four pounds of common salt, and one pound of super-phosphate of limc, and 
plaeed in a trongh. The pigs deroured it with eagerness; and, from this time, the tumors began to dininish, and entirely disappeared in six weeks. Three pigs consumed nine pounds in the first fortnight, six ponnds in the seeond, and nine pounds during the third.

Tluec sets of pigs, each divided into twelve pens of three pigs each, were devoted to three series of experiments, witl the various quantities of the food mentioned; in one series barley-meal taking the place of Indian corn, and the third series being devoted to the trial of dried Newfoundland eodfish-an artiele whieh eould be supplied in large guantities at a moderate priec, in eonneetion with the other food named. The amount given varied from one to two pounds of eodfish per day. It was in all cases boiled, and a portion of other food mixed with the soup thus obtained.

The following are the more simple of the conclusions at whieh $\mathrm{Mr}$. Lawes arrived: Indian eorn or barley-lneal with a linited supply of bran is very good food, the bran adding to the value of the manure. Where the pigs had unlimited aceess to three kinds of food, viz., the highly nitrogenous pulse mixture, the non-nitrogenous Indian meal, and bran, which is moderately nitrogenous-they gradually discontinued tho proportion of their consumption of the first, as they approached maturity, and throughout only consumed five per cent. of bran. The average consumption of eorn per pig per week was sixty pounds, or about nine pounds per day, which produced ten to twelve pounds of meat per week, or about one and a half pounds per day. There was a very rapid deerease in the rate of consumption of food to a given weight of animal as it fattened. The ncarer a fattening animal approached maturity, the greater was the proportion of fat in the gross inerease obtained.

Indian eorn and barley-meal eontain less than two per eent. nitrogen, bran about two and three-quarters per eent. beans and lentils about four and a half per eent., and dried codfish about six and a half per cent. Dried codfish contains less than one per eent. of fatty matter; beans and lentils two and a quarter per cent., barley-meal about the same, and Indian eorn and bran about five per eent.

It was found that "tlue larger the proportion of nitrogenons eompounds in the food, the greater was the tendeney to increase in frame and flesh, but that the inaturing or ripening of the animal, in faet, its fittening, depended very inuch more on the amount of "certain digestible non-nitrogenous eonstituents in the food.' It also appeared that some of the eheaper highly nitrogenous foods wonld produee a given amount of gross increase more economically than the expensive oncs (peas, beans) whiel are usually preferwed by pork-feeders.

"If the anount of gross produce in meat in return for a given amount of food, of a given money value-is alone to be taken into consideration, then, in addition to roots, wash, etc., it would be most advantagcous to rely for fattening upon lighly nitrogenous foods, such as dried fish, or animal refuse, or leguminous seeds, beans, lentils, and the like, because not only would the weight be obtained at less cost than by the use of cereal grains, but the manure-thi' value of whieh must never be lost simht of in calenlating the cconomy of the feed processwould be much isher than if the latter were employed. But it is not 
a large anount of gross increase that inakes the farmer's profit upon his stics. When pigs are fed frecly upon highly succulent food, such as cooked roots, the refuse of starch, herbs, and the like, they are frequently found to give a very rapid incrcase. But pork so fed is found to sink rapidly in the salting process, and to waste considcrably when boiled. And although the first batch of pigs so fed may fetch a good price, their character is at once detected, and the market closed against a second sale.

"On the other hand, when pigs are fattened upon the highly nitrogenized leguninous seeds-peas being, however, much less objectionable than some others-the lean is hard, and the fat wastes in cooking. Fish, flesh, and strong oily matters give the pork a rank favor.

"Finally, it is the interest of the farmer to use highly nitrogenous leguminous seeds, and cven refuse flesh, if at eommand, during the eallier and growing stages of his bacon hogs. 13ut if a constant markct is to be secured for pork, barley-Ineal or other cereal grain must supersede crury thing else as fattening proceeds." Thus Mr. Lawes eonfirms Mr. Tyrrel, and gives us a golden maxim for making a pig pay - a little bran or bean ineal, and plenty of Indian corn.

Diseases of Swille.-In order to prescribe with any reasonable hopes of success, for any animal, a knowledge of that animal's anatomy, pliysiol$0 \leq y$, and habits when in health, are indispensable, and an intinate acquaintance witl the eharacter's of the substances cinployed as remedies. we would not recommend you to place any eonfidence in books published by quacks, and purporting to contain infallible specifics for the several diseases to which live-stock arc liable. Veterinary text-books, written by competent persons, are very different things. A lost of honorable names stand upon record, on the face of their publications, in proof of the colrectness of my assertion. By diligent study of these books, farmers night, I have little doubt, evcutually arrive at a very respectable sliare of vetcrinary knowledge; acquirc a tolerable idea of the internal structure of the several inhabitants of the farm-yard, and of their physiology; by practical observation they would become able to detect the presence of disease from the symptoms present, and be able to adopt such a coursc of treatinent as might be suggested in the books they possessed. Under these circunstances, apply, if possible, to a regular veterinary surgeon.

Swinc arc by no means the most tractable of patients. It is any thing but an easy matter to compel them to swallow any thing to which their appetite does not incite then, and hence, "prevention" will be found "better than cure." Cleanliness is, in my opinion, the great point to be insisted upon in swine managencnt; if this, and warmth, bc duly attended to, the animal will not, save in one case perhaps in a hundred, become affected with any ailment.

As, however, even under the most careful system of managenent, an occasional disappointment may occur, the reader is furnished with the following bricf view of the principal complaints by which some are, under the most unfuvorable eircumstances, liable to be attacked, and the plainest effectual mode of sanatory treatment, in such cases, to be a.lopted. 
The prineipal diseases to which swine are liable are:-1. Fever; 2. Leprosy; 3. Murrain ; 4. Measles; 5. Jaundiee; 6. Foul skin; 7. Munge; 8. Staggers; 9. Craeklings; 10. "Ratille," or swelling of the spleen; 11. Indigestion, or surfeit; 12. Lethargy; 13. Heavings; 14. "Diarrhøea;" 15. Quinsy; 16. Tumors; 17. Catarth.

All which dangerous and often fatal maladies may be PREVENTED from oeeurring by the simple attention to eleanliness already reeommended, with jndieious feeding. A hog ean be relieved by bleeding, when sueh an operation will effeet relief, whether he like to submit or not; but it is very questionable whether he ean be eompelled to swallow medieines without his perfeet eonsent and eoneurrenee; these, therefore, will best be administered by stratagem, and the hog's appetite is the only assailable point he has.

Fever.-The symptoms are, redness of the eyes, dryness and heat of the nostrils, the lips, and the skin generally; appetite gone, or very defeetive, and the presenee, usually, of a very violent thirst. Of eourse, no symptom ean be regarded as individually indieative of the presenee of any partieular disease; these, wlieh I have named, might, individually, indieate the presenee of many other disorders, nay, of no disorder at all, but eollectively, they point to the presenee of fever as their origin.

Let the animal, as soon as possible after the appearanee of these symptoms, be bled, by eutting the veins at the baek of his ears. The pressure of the finger raises the vein, and you ean then puneture it with a laneet. If the bleeding from this ehannel be not suffieiently eopious, you must eut off a portion of his tail; and after bleeding let him be warmly housed, but, at the same time, while proteeted from eold and drauglits, let the sty be well and thoroughly ventilated, and its inmate supplied with a eonstant sueeession of fresh air. The bleeding will usnally be followed, in an hour or two, by sueh a return of appetite as to induee the animal to eat a suffieient quantity of food to admit of your making it the vehiele for administering sueh internal remedies as may seem advisable. The best veliele is bread steeped in broth. The hog, however, sinks so rapidly, when onee he loses his appetite that no depletive medieines are in general neessary or suitable; the fever will usually be found to yield to the bleeding, and your only objeet need be the support of the animal's strength, by suall portions of nourishing food, adininistered frequently.

Do not, however, at any time suffer your patient to eat as mueh as his inelination might prompt; the moment he appears to be no longer ravenous, remove the mess, and do not offer it again until after a lapse of three or four hours. It is a singular faet, that as the hog surpasses every other animal in the faeility with which he aequires fat, he likewise surpasses all otliers in the rapidity with whieh his strength beeomes prostrated when onee his appetite deserts him. The Freneh veterinarian praetiee reeommends the addition of peppermint to the bread and brotll. If the animal be not disgnsted by the smell, it may be added; and if the bowels be eonfined, the addition of eastor and linseed oil, in equal quantities, and in the proportion of two to six ounees, according to the size of the hog, should not be omitted. 
If you find yourself unable to restore the animal's appetite, the case is nearly hopeless, and you may regard its return as one of the most in. falliblc symptoms of returning convalescence. It is, however, possible to administer medicine to the pig by force; although, for my own part, I cannot say that I have ever found it practicable.

There is a description of fever that frequently occurs as an epizootic. It often attacks the male pigs, and generally the most vigorous and the best-looking, without any distinction of age, and with a force and promptitude absolutely astonishing; for in the space of twelve hours, I have sometimes seen a whole piggery suecumb: at other times its progress is much slower; the symptoms arc less intense and less alarming; and the veterinary surgcon, employed at the commencement of the attack, may promise himself some suecess.

The Causes of the Disease are, in the majority of cases, the bad sties in which the pigs are lodged, and the noisome food which they often contain. The food which the pigs meet with and devour, are the remains of mouldy bread and fruit, especially those of pease and lentilsthe fermentation and decomposition of which farinaceous substances, and especially the bran which is too frequently given to them, and the prolonged action of which determine the most serious in the whole economy. In addition to this, is the constant lying on the dung-heap, whence is exhaled a vast quantity of de!eterious gas; also, whcre they remain far too long, on the muddy or arid ground, or are too long exposed to the rigor of the season.

As soon as a pig is attacked with disease, he should be separated from the others, placed in a warm situation, some stimulating ointment to be applied to the chest, and a decoction of sorrel administered. Frictions of vinegar should be applied to the dorsal and lumbar region. The drinks should be emollient, slightly imbued with nitre and vinegar, and with aromatic fumigation about the belly. If the fever now appears to be losing ground, which may be ascertained by the regularity of the pulse, by the absence of the plaintive cries that were before heard, by a respiration less laborious, by the absence of convulsions, and by the nonappearance of blotelies on the skin, there is a fair chance of recovery. We may then be content to administer, every second hour, the drinks and the lavements already prescribed, and to give the patient his proper allowance of white water, with ground barley and rye. When, howcver, instcad of these fortunate results, the syinptoms are redoubling in intensity, it will be best to destroy the animal; for it is rare, that, after a certain period, there is much or any chance of recovery. Bleeding, at the ear or tail, is seldom of much avail, but occasionally produces considerable loss of vital power, and augments the putrid diathesis.

Leprosy. - The symptoms of this complaint usually conmence with the formation of a small tumor in the eye, followed by general prostration of spirits; the head is held down and the whole frame inclines toward the ground: universal languor succeeds; the animal refuses food, languishes, and rapidly falls away in flesh; blisters soon make their appearance beneath the tongue, then upon the throat, the jaws, the head, and the entire body. The tlesh of a leprous pig is said to possess most pernicious qualities, and to be wholly unfit for lumman food If tho 
animal be killed in the very first stage of the disease, however, the affection is only supcrfieial, the flesh nothing the worsc, but rather improved in tenderness, and indeed, not to be distinguished from that of a perfeetly sound animal. The cause of this discase is want of cleanliness, abscnce of fresh air, want of due attention to ventilation, and foul fecding. The obvious cure therefore is-first, bleed; clean out the sty daily; wash the affected animal thoroughly with soap and watcr, to which soda or potash has becn added; supply him with a clcan bed; keep him dry and comfortable ; let him have gentle cxcreise and plenty of fresh air; limit the quantity of his food, and diminish its rankness; give bran with wash, in which you may add, for an average-sized hog, say one of one hundred and sixty pounds' weight, a tablespoonful of the flour of sulphur, with as much nitre as will cover a sixpence, daily. A few grains of powdered antimony may also be given with effect.

Ilorrain.-Resembles leprosy in its symptoms, with the addition of staggering, shortness of breath, diseharge of viseid matter from the eyes and the mouth. The treatment should consist of cleanliness, eoolness, blceding, purging, and limitation of food. Cloves of garlic have bcen reeommended to be administercd in cascs of murrain. Garlic is an antiseptic, and as, in all these febrile diseases, there exists more or less a degree of disposition to putrefaction, it is not improbable that it may be found uscful.

Measles.-This is one of the most common discases to which hogs are liable. The symptoms are redness of the cyes, foulness of the skin, depression of spirits, decline, or total departure of the appctite, small pustules about the throat, and red and purple eruptions on the skin. These last are more plainly visible after death, when they impart a peculiar appearance to the grain of the meat, with fading of its color, and distension of the fiber so as to give an appearancc similar to that which might be produced by puncturing the flesh.

Suffer the animal to fast, in the first instance, for twenty-four hours, and then administer a warm drink, containing a drachm of carbonate of soda and an ounce of bole Armenian; wash the animal, clcanse the sty, and ehange the bedding; give at evcry feeding, say thrice a day, thirty grains of flour of sulphur, and ten of nitre. It is to. dirt, combined with a eommon fault too littlc thought of, viz., giving the steamed food or wash to the hogs at too high a temperature, that this disease is gencrally to be attributed. It is a troublesome malady to eradicate, but usually yields to treatment, and is rarely fatal.

Jiundice.-Symptoins-yellowncss of the white of the cye, a similar hue extending to the lips, witl sometimes, but not invariably, swelling of the under part of the jaw. Bleed bchind the ear, diminish the quantity of food, and give a smart apericnt every sccond day. Aloes are, perhaps, the best, combined with colocynth: the dose will vary with the size of the animal.

Foul Skin.-A simple irritability or foulness of the skin will usually yicld to clcanliness and a washing with solution of chloride of lime, but if it las been neglected for any length of timc, it assumes a malignant character, scabs and blotches, or red and fiery eruptions appear, and the discase rapidly passes into mange. 
Ninge, - If the foul hide already described had been properly attended to, and the remedies necessary for its removal applied in suffieient time, this very troublesome disorder would not have supervened. Mange is supposed, by most medieal men, to owe its existence to the presence of a minutc insect, called "acarts scabici" or "mange-fly," i minute creature, which burrows beneath the cuticle, and in its progress through the skin occasions much irritation and annoyance. Others, again, do not conecive the affection styled mange to be thus produced, but refer it to a diseased state of the blood, which, as is usually the casc, eventually conveys its morbid influences to the superficial tissues. Much has been, and still more might be said ou both sides of the question, but such a discussion is scarcely suitable to the pages of a popular work. The symptoms of the disease are sufficicntly well known, consisting of seabs, blotches, and soinetimes multitudes of ininutc pustules, on different parts of the body. If neglected, these symptoms will become aggravated; the disease will rapidly spread over the entire surface of the skin, and if suffered to proceed upon its course, unchecked, it will cre long produce decp-seated nlcers and malignant sores, until the wholc carcass of the poor affected animal becomes one mass of corruption.

The Causes of Mlange have been differently stated; some referring them to too high, and others to too low a diet. The cause is to be looked for in dirt, accompanied by hot-feeding; hot-feeding alone would, perhaps be inore likcly to produce measles than mange, but dirt would unquestionably produce the latter discase, even if unaided by the concomitant el'ror of hot-feeding.

Hogs, however well and properly kept, will occasionally become affected with this, as well as with other disorders, from eontagion. Few diseases arc nore easily propagated by contact than mange. The introduction of a single affected pig into your estal)lislunent may, in one night, cause the scizure of scores, and probably furnish you with a three montlıs' hospital experience. Do not, therefore, introduce any fonlskinned pigs into your piggery ; in fact, it wonld be a very safe proeecding to wash cvery uew purchise with a strong solution of ehloride of lime. This substance is very cheap, and a little trouble, when applied as a preventive, is surcly preferable to a great dcal of both troublc and disappointment when you are compclled to resort to it to cure.

If a hog be only aillicted with a mange of moderate virulence, and not of very long standing, the best mode of treatment to be adopted is:

1. IVasli the animal from snout to tail, leaving no portion of tlic body uncleansed, with soft soap and water.

2. P'ut him into a dry and clean sty, which is so built and sitnated as to command a eonstant supply of freslı air, without, at the sine time, being exposed to cold or dranglit; let him have a bed of clean, fresh straw.

3. Rednce his food, both in quality and in quantity; let boiled or steamed roots, with buttermilk or dairy wash, supply the place of halffermented brewers' graius, house-wash, or any otlicr description of fecding calculated to prove of a leating or inflammatory character. It is, of course, scarcely neccssary to add, that those who have been feeding their swinc on hor se-flesh, or chandlers' greaves, cannot be surprised at 
the oceurrenee of the disease; let them, at all events, desist from that rank and nasty mode of feeding, and turn to such as has been indieated.

4. Let your patient fast for five or six liours, and then give, to a log of average size-Epsom salts, two ounees, in a warm bran wash. This quantity is to be inereased or diminished as the size may require. The above would suffiee for a hog of $160 \mathrm{lbs}$. It should be previonsly mixed with a pint of warn water. This should be added to about half a gallon of warm bran wash. It will aet as a gentle purgative.

5. Give in every meal afterward-of flour of sulphur, one tablespoonful ; of nitre, as mueh as will eover a sixpenee, for from three days to a week, aceording to the state of the disease. When you pereeive the seabs begin to lieal, the pustules to retreat, and the fiery sores to fade, you may pronounee your patient eured. But before that pleasing result will make itsappearanec, you will pereeive an apparent inerease of violeneo in all the symptoms-the last effort of the expiring malady, as it were, ere it finally yields to your eare and skill.

6. There are, however, some very obstinate eases of mange oecasionally to be met with, which will not so rearlily be subdued. When tho above mode of treatment has been put in practiec for fourteen days, witlout effeeting a eure, prepare the following: train oil, one pint; oil of tar, two drachms; spirits of turpentine, two drachms; naphtha, one drachın; with flour of sulphur, as much as will form the above into the eonsisteney of a thick paste. Rub the animal, previously washed, with this mixture-let no portion of the hide eseape you. Keep the hog dry and warm after this applieation, and suffer it to remain on lis skin three entire days. On the fonrth day, wash him onee more with soft soap, adding a small quantity of soda to the water. Dry the animal well afterward, and suffer him to remain as he is, having again changed his bedding, for a day or so: continue the sulphur and nitre as before. I have never known any ease of mange, however obstiuate, that would not, sooner or later, give way hefore this mode of treatment.

7. Your patient being convaleseent, whitewash the sty ; fumigate it, by placing a little eliloride of lime in a eup, or other vessel, and pouring a little vitriol upon it. In the absenee of vitriol, however, boiling water will answer nearly as well.

Finally, all mereurial applieations are, as much as possible, to be avoided; but, above every thing, avoid the use of ointments eomposed of hellebore, corrosive sublimate, or tobaeeo-water, or, in sloort, any poisonous ingredient whatever; very few cures have ever been effeeted by the use of these so-ealled remedies, but very many deaths have resulted from their adoption.

Staggers, eaused by exeess of blood to the head; bleed freely from behind the ears, and purge.

Crackings will sometimes appear on the skin of a hog, especially abont the root of the ears and tail, and at the flanks. These are not at all to be eonfounded with mauge, never resulting from any thing but exposure to extremes of temperature, without the suffering animal being able to avail himself of sueli protections as, in a state of nature, instinet would have indueed him to adopt. They are peeuliarly troublesome in tho heats of summer, if the hog be exposed to a hot sun for any length 
of time, without the advantage of a marsh or pool in whieh to lave his parehed limbs and half-seorehed eareass. Anoint the eraeked parts twiee or thrice a day with tar and lard melted up together.

Ratille, or Swelling of the Spleen.-The symptom most positively indicative of this disease, is the eircumstance of the affected animal leaning toward one side, eringing as it were, from internal pain, and bending toward the ground. The eause of the obstruetion on which the disease depends is over-feeding, permitting the hog's indulging its appetite to the utmost extent that gluttony may prompt and the eapacity of its stomaeh admit of; a very short perseveranee in this mode of management will produce this, as well as other maladies deriving their origin from a depraved condition of the sccretions and obstruetion of the exeretory duets.

On first pereeiving the eomplaint, elear out the alinentary eanal by means of a strong aperient. If you think you can manage it, you may administer this foreibly, by having the moutl kept open by two cords, that attaelied to the ipper jaw being tlrown across a joist, and drawn just so tight as to eompel the patient to support bimself on the extremities of his fore-toes; or allow the aninal to fast for from four to five hours, he will then take a little sweet waslı or broth, and in it you may mingle a dose of Epsom salts, proportioned to his bulk. This will generally effeet the desired end of a eopious evaeuation, and the action of this medieine on the watery secretions will further relieve the existing diseased state of the spleen. Many recommend bleeding; and if the affeetion have eontinued for any length of time, it should be resorted to at onee; when the disease is, however, diseovered ere it has attained any eonsiderable head, the apcrient will suffice. The Freneh veterinarians reeommend the expressed juiec of the leaves and tops of wormwood and liverwort to be given, half a pint for a dose. The deeoetion of these plants produeed by boiling them in soft water for six hours, may be given in doses of firom lialf a pint to a pint and a half, aeeording to the size, age, ete., of the patient.

Seaminony and rhubarb, mixed up in a bran mash, or with Indian meal, may be given with advantage the following day, or equal portions of blue-pill mass and eompound eoloeynth pill, formed into a bolus with butter, and the animal, having been kept fasting the previous night, will probably swallow it; if he will not do so, let his fast eontinue for a eouple of hours longer. Lower the animal's diet, and keep him on redueed fare, with exereise, and if you ean manage it, grazing, until the malady has quite passed away; if you then wish to fatten, remember to do so gradually; be eautious of at once restoring the patient to full diet.

Surfeit.-Another name for indigestion; the symptoms are sueh as might be expeeted-panting, loss of appetite, swelling of the region about the stomaeh, etc., and frequently throwing up the eontents of the stomael. In general, this affection will pass away, provided it is only permitted to eure itself, and all food earefully kept from the patient for a few hours; a small quantity of sweet grains, with a little bran-wash, may then be given, but not nearly as muelı as the animal would wish to take. For a few days the food had better be limited in quantity, and 
of a washy, liquid nature. You may then resume the ordinary food, only observing to feed regularly, and remove the fragments remaining after each meal.

Lethirgy.-Symptoms, torpor, and desire to sleep, hanging of the head, and frequently redness of the eyes. The apparent origin of this disease is the same as the last, only in this instance acting upon a hog having a natural tendency to a redundancy of blood. Bleed at the back of both the ears as copiously as you can, and if you cannot obtain a sufficient quantity of blood from these sourees, have recourse to the tail. Administer an emetic, of which a decoction of chamomile flowers will be found the safest; or a sufficient dose of tartar emetic, which will be far more certain. After this, reduce for a few days the amount of the animal's food, and administer a small portion of sulphur and nitre in each morning's meal.

lieavings, or Inflammation of the Lungs.-This disease, which has acquired its name from the prineipal symptom by which it is characterized, is scareely to be regarded as curable. If indeed, it were observed in its first stage, when indicated by loss of appetite, and a short, hard cough, it might run some chance of being got under by copious bleeding, and frietion with stimulating ointment on the region of the lungs, minute and frequent doses of tartar emetic should also be given in butter, all food of a stimulating nature earefully avoided, and the animal kept dry and warm. Under these eireumstanees, there wonld be no reason absolutely to despair of a cure, but it would be advisable at the same time, if the hog, when this primary stage of the malady was diseovered, were not in very poor condition, to put him to death. If once the heavings set in, it may be ealenlated with confidenee that the formation of tubercles in the substance of the lungs has begun, and when these are onee formed, they are very rarely absorbed. The cause of this disease is damp lodging, foul air, want of ventilation, and unwholesome food. It is difficult to suggest what should be done when matters have reached this pass, or what remedies would prove of any service. It is now too late in most cases to resort to blood-letting, and the hide of the hog is so tough that it is not easy to blister it, for the purpose of counter-irritation; you may, however, try the following, though perhaps the knife might be best, if only to relieve the poor sufferer, and provide against the danger of infeetion; for it may be as well to state that, once tubereular formation becomes established, the disease may be communicated through the medium of the atmosphere, the infectious influenee depending upon the noxions particles respired from the lungs of the diseased animal. Shave the hair away from the ehest, and beneath each fore-leg; wet the part with spirits of turpentine, and set fire to it; you will, of course, have had the patient well secured, and his head well raised, and have at haud a flannel cloth, with which to extinguish the flame, when you coneeive it has burned a suffieient time to produce slight blisters ; if earried too far, a sore would be formed, which would be productive of no good cffects, and eanse the poor animal unnecessary suffcring. Calomel may also be used, with a view to promote the absorption of the tubereles, but the suceess is questionable.

Dinrrhea, or Looseness.-The symptoms, of course, require no com- 
ment, as they constitute the disease. Before attempting to stop the disehurge-which, if permitted to continue uncheeked, would rapidly prostrate the animal's strength, and probably terminate fatally-ascertain the quality of food the animal has recently had. In a majority of instances, you will find this to be the origin of the disease; and if it has becn perecived in its incipient stage, a mere change to a more binding diet, as eorn, flour, etc., will suffice for a cure; if you have reason to apprehend that acidity is present, produced in all probability by the hog having fed upon eoarse, rank grasses in swampy places, give some chalk in the food, or powdered egg-shells, with about half a drachm of powdered rlubarb; the dose of course varying with the size of the hog. In the acorn season, and where facilities for obtaining them exist, they alone will be found quite suffieient to effect a cure. When laboring under this eomplaint, dry lodging is indispensable; and diligence will be necessary to maintain it and cleanliness.

Quilsy, or Inflammatory Affeetion of the Glands of the Throat,-Shave away the hair, and rub with tartar emetic ointment. Stuping with very warm water is also useful. When external suppuration takcs place, you may regard it as rather a farorable symptom than otherwise. In this case, wait until the swellings arc thoroughly ripe; then, with a sharp knife, make an ineision through the entire length, press out the matter, wash with warm water, and afterward dress the wound with any resinous ointment, or yellow soap with coarse brown sugar.

Tumors, or llard Swellings, which make their appearance on several different parts of the animal's body. It would not be casy to state the causes which give rise to these tumors, for they vary with circumstances. They are not formidable, and require only to be suffered to progress until they soften; then make a free incision, and press out the inatter. Sulphur and nitre slould bc given in the food, as the appearance of these swellings, whatcver be thicir causc, indicates the necessity of alterative medicincs.

Catarrl, an inflammation of the mucous membranes of the nose, etc., if taken in time, is easily eured by opening medieine, followed up by warm bran-mash, a warm, dry sty, and abstinence from rich grains or stimulating farinaecous diet. The eause has probably been exposure to drafts of air-sec to it.

The instructions given comprisc all that the amatcur will ever find neeessary for domestic practiec, and far more than be will evcr find occasion to follow, if he liave attended to eleanliness, dry lodging, regularity of feeding, the use of salt in the food, and the addition of occasionally a small quantity of sulphur and nitre to the morning's meal.

Medieines Employel in the Treatment of Swime.-Few medicines are requisite in the trcatment of swine. Of these the clief are eommon salt, Epsom salts (dose, from onc-half to two ounces); sulphur (dose, onchalf to one and a half ounees); uscful as the basis of ointments for cutaneous diseases; nitrate of potass (dose, one seruplc to one draelım); ginger (dosc, one scruple to one drachm); croton-oil (dose, one to three drops); eastor-oil (dose, one-half to two ounces); jalap (dose, one scruple to one half-drachm). Besides these, we may mention oil, mereurial vintuncut, and turpentine, as ingredients in ointmcuts, mixed with 
sulphur, for cutaneous affections. Turpentine, it may be observed, is useful in cases of worms; it may be given in doses of about half an ounce or more, in gruel.

SLAUGITERIXG AND CURING.-The Almighty Creator, when he had formed inan, and placed him upon the earth, gave him power of life and death over all the inferior animals. 'This power was, however, given to him to be used, not to be abused; while permitted to slay for food, clothing, or other necessaries-nay, luxuries of life-it was never designed by our all-benevolent as well as omnipotent Lord that this power should be converted into a mediun of eruelty, or that life should be taken away from any of his creatures in any other than the most humane manner possible. The necessity of humanity toward animals thus stands as not only a high moral duty, but one absolutely enjoined as a divine ordinance; it is also a part and parcel of all that is noble or excellent in human nature.

It is a mistake to suppose that this poor animal is insensible to pain. The poor hog does indeed feel, and that most aentely; well would it be for him that he did not, for then what miseries would he not be spared!-he would not then care whether he was put out of pain at onee, or suffered to hang up by the hind-legs, the limbs previously dislocated at the hoeks, between the tendons and the bone of which has been passed the hook by which he is suspended. Were he indeed insensible to pain, it wonld of course be a matter of indifference whether or not he were suffered to die first, or-as soon as he had bled a sufficient quantity - was, still living and breathiug, plunged into boiling water, in order to remove his liair; or then, with a refinement of cruelty that would not even permit of his being put out of his misery so soon, removed from the eauldron, ere life or feeling had yet departed, opened, and disemboweled alive.

We should be sol'ry to give pain to the feelings of any of our readers, but we had rather hurt their feelings than leave a suffering, a tortured quadruped, and that, too, one so useful to us, to experience sueh an ungrateful return, in the shape of such terribly revolting miseries. $\mathrm{Ve}$ have deseribed only what we have personally witnessed, and we trust that what we have said may lead master-buteher's'and others to ascertain the eonduct of their slaughterers, and the manner in whieh they perform their necessary but painful duty.

The usual mode of killing a log in the country parts of England is, or used lately to be, by fastening a rope around the upper juw, and throwing it across a joist or beam; this is hauled by an assistant just suffieiently tight to eompel the animal to support himself upon the extremities of his toes, with his snont elevated in the air. The buteher then kneels in front of him, and taking a slarp and pointed knife, first sliaves away the hair from a small portion of the front of the throat, then gently passing the sliarp-pointed steel through the superfieial fat, gives it a plunge forward, a turn, and witlıdraws his weapon. A gush of blood follows, which is usually eaught in proper ressels, for the purpose of forming black puddings. The rope is somewhat slaekenedthe victim totters, reels, the eye glazes-his screams eease-he falls, and life would speedily become extinet; but, alas! the butcher is paid by 
the job, he is in a hurry, and ere the brcath is out of the poor brute's carcass - nay, ere he ceases to struggle or moan-he is tumbled in to the scalding tub; he is then withdrawn in a second, placed upon a table, the hair and bristles carefully removed by scraping with a knife; disemboweling follows-and it is well if the poor wretch has perished before that process commenced.

In olden times it would appcar that our butchers were less hasty, or more merciful. All the skulls of logs were broken in upon the frontal bones, precisely in the same manner as are now the skulls of oxen and other animals. Were the hog first deprived of sensibility by compression of the brain, as produced by a violent blow upon the forehead, he would be a passive victim in the butcher's hands, who could not only perform all the remainder of the process with more humanity, butand think well of it, such of you as inight probably be swayed by no other consideration - with more dispatch and less trouble.

We are happy in being able to add, that a humane custom of knocking the hog on the head beforc cutting his throat is rapidly gaining ground, and that no respectable butcher will allow it to be dispensed with. In the country parts of both England and Ireland, however, the old abuses are still permitted to exist; and we are grieved to say that everywhere, with a very few honorable exceptions, the barbarous practice of plunging the hog into the scald while yet living, is still systematically and designedly adopted. A very respectable man surprised us the other day by deliberatcly telling us that "a hog will no way scald so well as when the life is in him." This is, lowvever, a mistake. It is only neeessary not to suffer the animal to become cold and stiff. Readers-we raise our voicc in behalf of a very useful and most cruellytreated animal-may we beg of all to unite with us in the cause of humanity, and then we shall not have raised our voice in vain.

And now, having supposed the animal killed and dressed, let us proceed to inquire into the most approved modes by which its flesh may be converted into bacon and ham. The hog should be left fasting for full twenty-four hours before killed; and after the carcass has hing all night, it should be laid on its back upon a strong table. The liead shonld then be cut off close by the ears, and the hinder feet so far below the houghs as not to disfigure the liams, and leave room sufficient to hang them up by ; after whieh the carcass is divided into equal halves, up the middle of the back-bone, with a eleaving-knife, and, if necessary, a hand-mallet. Then cut the ham from the side by the second joint of the back-bonc, which will appear on dividing the carcass, and dress the ham by paring a little off the flank, or skinny part, so as to shape it with a half-round point, clearing off any top fat that may appcar. The curer will next cut off the sharp edge along the back-bone with a knife and mallet, and slice off the first rib next the shoulder, where he will find a bloody rein, which must be taken out, for, if left in, that part is apt to spoil. The corners should be squared off when the han is cut out.

This passage is quoted because it describes a novel mode of cutting bacon, and which we have not as yet scen practiced. The ordinary practice is to eut out the spine or back-bone, and, in some English 
eounties, to take out the ribs also. It is only in porkers that the backbone is thus divided.

The inost approved mode of saving bacon, as practiced by a majority of those extensive eurers who have kindly favored us with the necessary details of this portion of our subject, is as follows: if the swine you design killing have been a recent purchase, and have been driven from a distanee, so as to have beeome winded or jaded, it is right that they should be kept up for a week, or perhaps more, until the effects of the journey have been entirely removed, and the animals restored to their original tranquillity and primeness of condition; during this interval they should be fed upon meal and water. A difference of opinion exists, as to whether this food should be given in a raw state or boiled. We have taken some pains to asecrtain the trutl, and have no hesitation in pronouneing in favor of the latter; at the same time, however, the mess should be given in a perfectly cold state, and not of too thick consistence. Some recommend that a small dose of nitre should be given daily in the food for a fortnight previous to killing; others pronounce this to be unnecessary; but all unite in recommending a very considerable reduction in the animal's food for two or even three days before killing, and a total deprivation of food for at least the last twelve bours of life.

In the eountry distriets of Ireland, the hog is usually secured by the hind-leg to a post or ring, the head is fastened to another; the animal is this seeurely strapped down upon a sloping slab or table, and the head is severed from the body by means of a sharp knife. I am informed that the bacon of a hog thus killed is more easily saved, and is superior in flavor and color.

The ordinary mode of killing a hog is, we are most happy to say, gradnally approximating to such as humanity would dictate. It is thus: a flat stage or table, inclining downward in one direction, is prepared; the pig receives a powerful blow with a mallet upon the forehead, which effectually deprives him of sensation; he is then thrown upon the stage, and a knife plunged into the eliest, or rather into that spot where the eliest meets the neek. The blood flows freely, and is reeeived into vessels placed for the purpose. A large tub or other vessel has been previously got ready, which is now filled with boiling water. The eareass of the hog is plunged into this, and the hair is then removed with the edge of a knife. The hair is more easily removed if the hog be sealded ere he stiffens or becomes quite eold, and henee some butehers eruelly eonecive it advisable to seald hin while yet there is some life in him. The animal is now hung up, opened, and the entrails removed; the head, feet, ete., are eut off, and the eareass divided, entting up at each side of the spine. A strong knife and mallet are neecssary for this purpose, and will be found to answer better than a saw.

IIOW TO CURE BACON ANB IIMMS.-One and a lialf pounds of salt and one ounee of saltpetre ar'e enough to salt fourteen pounds of meat, or two hundred weight of meat will require twenty-four pounds of salt.

The following is Mr. Rowlandson's plan :- " Having cut up a well-fed hog, which absorbs much less salt than an ill-fed animal, and runs very little risk of being over-fed, salt, and saltpetre, in the proportions de- 
seribed, must be sprinkled over the flitehes, ctc., and then they must be laid onc over the other in a slatc trough, or a wooden trough lined with lead, to the number of half a dozen; in the eourse of twentyfour hours, or forty-cight hour's, according as the salt is converted into brine (and this will depend on the weather-in frosty wcather the meat will not take the salt, and in moist weather it is apt to spoil), the sides are removed, rubbed, replaeed in inverse order, the top at the bottom, with a little fresh salt sprinkled bctwcen each coursc, and the brine thrown over the whole. In favorable weather for euring, onee turning and replacing will be found enough, and will not oceupy more than a wcek.

Baeou is eured in very different ways. For domestie use, it is usually laid upon a tablc, and salt, with a little nitre added, well rubbed in, first on one side and then on the other, cither with the bare hand or the salting-glove. Some straw is then plaeed upon the floor of an out-house, a flitch laid thcrcon, with the rind downward-straw laid above this, then another flitch, and so on; above the whole is plaeed a board, and, heavy stoncs or weights above all. In three wecks or a month the meat is suffieiently salted, and is liung up on hooks in the kitehen raftcrs. The general practice of burning wood and turf in Irish kitchens, imparts a sweetness to the baeon thus saved that is not to be met with in any whieh you ean purchase.

Another method is as follows:-preparc a pickle, by boiling eommon salt and nitre in watcr ; mix, for a single hog, of tolerable sizc, one ponnd of eoarse brown sugar, with half a pound of nitre; rub this wcll in with the salting-glove, then put the meat into the pickle, and let it lie in this for two days; afterward take it ont of the piekle, and rub it with salt alone, then put it baek into the piekle.

For a mild cure-form sweet pickle, by boiling molasses with salt and water ; rub the mcat with sugar and nitrc-add a small portion of strong pickle to the meat-put the meat into this, and let it lic in it for abont threc weeks. If therc be any spare room in the eask, fill up with inolasses-eight pounds of salt; one pound of nitre, and six pints of molasses will about suffice for eaeh hundred weight of meat; and will take about five gallons of water.

In about three wceks-less or more time being required aeeording to size-takc the meat out of pickle, and liang it in the drying-housc. While in the drying-house, the flitches should be hung, ncek dowuward. You may eut ont the ham, and trim the fliteh aeeording to faney-nearly evcry county in England has in this respeet a fashion of its own.

You then remove your hams and baeon to the smoking-housc; they should not be suffered to touch each other; with this preeaution you may hang them as elose as you plcase. Smoke-houses are of every dimension, but the smallest answer as wcll as the most extensive. Bcfore suspending the meat in the smoke-house, it should be previously well rubbed over with bran. The fire is madc of saw-dust, which burns with a low smouldering glow, giving out fur more smokc than if aetually flaming.

In the process of snoking, your meat will lose from about fiftecn to twenty pounds per hundred weight-a faet neeessary to be borne in mind.

Sometimes the hogs arc killed beforc they arrivo at full size, and 
their hair remored by singeing; the baeon and hams of these are said to possess peeuliar delicaey of flavor.

The best saw-dust for smoking hams or baeon is that made from oak, and it should be thoroughly dry. The saw-dust of common deal imparts a flavor of a disagreeable eharaeter, not unlike that of red herrings.

Westphalian Hams. - The genuine Westphalian baeon is partieularly good, but all sold under that name is not genuine; spurious WVestphalian hams are manufaetured to a considerable extent. The process of imitation is not diffieult, and none but one of the trade ean detect the imposture. The fine quality of Westphalian baeon depends on several eauses: the healthy and semi-wild life the swine are permitted to enjoy -their relationship to the wild boar-they are not fattencd to the fullest extent previous to killing. A large proportion of sugar and juniper-berries ale used in euring-the proportion being usually one and a half pounds of sugar to three of salt, and two ounees of nitre. The smoke is also applied in a cold state. This is, pcrhaps, the principal seeret. The hams are all hung at the top of a very lofty building, and by the time the smokc reaehes them it is perfectly cold.

The ham of the Westphaliau hog elosely resembles that of the eommon old Irish breed; and the hams of that animal, when cured as has becn described, could not be distinguished from those of Westphalia by the nicest judge.

Limerick. - The bams cured iu Limeriek have long enjoyed considerable celebrity, and are supposed to be superior to any others-those of Westphalia and Hampshire alone cxeepted. Their exeellenee appears ehiefly to depend upon the sparing use of salt, and the substitution for it, to a great extent, of eoarse sugar, with judieious smoking. Some of the Limerick smoking-rooms are upward of thirty fcet in height.

Ilampshirc.-The Hampshire baeon is in grcater estecin than even the Westphalian-a eireumstance attributable to the superior exeellenee of the New-Forest swine to those of that country, while they sharc cqually with them the privilege of a forest life and aeorns. The Hanpshire curers smoke with saw-dust. In both this eonnty and in Berkshire, singeing is adopted more generally than sealding, and this proeess is considered superior to sealding, the latter being supposed to soften the rind and render the fat less firm.

The Wiltshire bacon is of peeuliarly delicious quality, but the eause is obvious, and is not to be referred to any of the details of the curing proeess. This baeon is prepared from dairy-fed pork - this is the true secret.

In some eounties the pig is skinned prior to curing. Some amount of additional profit is of course derivable from this pratiee, but the baeon is inferior, being liable to beeome rusty, as well as to waste in the boiling.

Hams and flitehes should always be hung up in a dry plaee, indeed it will be found useful to sew up the former in piees of eanvas or saeking, as is practieed with the Westphalian.

It is diffieult to save bacon in summer time, or in warm elimates, but a machine has reeently been invented, for whieh a patent has been obtained, whieh renders the saving of meat under the most adverse eir- 
eumstanees perfectly easy. The machine acts as a force-pump or syringe. Its extremity is inserted into the meat, and the handle worked; the brine, which must be verystrong, is thus forced through the grain of the meat, and it is effectually impregnated with it, and well eured long ero it could turn : there ean be no doubt but that this instrument is, under the eireumstanees deseribed, eminently useful-but it is no less ecrtain that meat so eured is not equal to that saved under ordinary eircumstances and in the ordinary manner; the grain of the meat is too much loosened by the use of the machine, and the texture is thus deteriorated; it should therefore only be used when necessity requires, and never by preference, where the ordinary proeess ean be adopted.

To extract the superabundant salt from your meat, prior to use, has long been a desideratum. The steeping it in water to which earbonate of soda has been added, is found useful; so is the addition of the same substance, or of lime, to the water in which it is boiled; so is changing the water, after the meat has been about half-boiled. Sailor's find washing the meat in sea-water very efficaeious, but I have made the discovery that this object ean be attained to a far fuller extent by a very simple ehemical process.

Put your meat to steep in tepid water, and after it has lain in it for some hours, add a small quantity of sulphurie acid. In three or four hours take it out, and wash it two or three times in water; to the third water add a small portion of earbonate of soda. Take your meat out, wash it again, and boil it for dinner. . You will find the salt nearly, if not wholly discharged; but you need not be surprised should the color of the ment be somewhat darkened-the deterioration does not extend farther; the flavor remains the same as when first eorned, and the article becomes as wholesome as fresh meat. It is possible that this simple process may be found useful in long voyages, for a long-continued nse of salted animal food, without a free use of vegetables, is found to contribute to the production of many diseases.

The following communication, coming from a curer by profession, will be found at onee interesting and useful :

"The hog is usually kept fasting for twenty-four hours previous to being killed. He is then brought to the slaughter-house, and dispatehed in the following manner: the butcher takes a mall (a hammer with a long handle, like those used for breaking stones on a road), and with it strikes the hog on the forehead; if he be an expert liand, a single blow will suffice to knoek the hog down and render him quite senseless. A knife is then taken, and the buteher stieks the animal in the lower part of the throat, just between the fore-legs. A boiler.or tnb, full of very hot or boiling water, is then prepared, in which the hog is inmersed until the hair becomes so loose that it can be seraped off with a knife quite elean; where there is no convenience of this kind, the same effect may be produeed by pouring boiling water over the hog. Tho log is then hung up by the hind-legs, ent up the middle, and the entrails taken out; after this, the eareass is left there for about twelve hours, to eool and beeone firm, when it is fit for boning or cutting up. Sonetimes, instead of scalding, the hog is singed by fire-burned straw is generally used for this purpose; and this is ealled 'singed pork.' 
"The following is the mode of boning or eutting: the pig is placed on a strong table or beneh; the head is then eut off elose to the ears; the hog is then opened down the baek, a eleaver or saw is used for the purpose, and both baek-bone and hip-bones are taken out, exeept in one or two plaees yet to be spoken of, where a different system is pursued. The hind-feet are then eut off, so as to leave a shank to the ham. The fore-legs are then eut round at the hough, the flesh seraped upward off the bone, and off the shoulder-blade, whieh is taken out quite bare, under the side. The saw is then run along the ribs, so as to eraek them; they then lie quite flat. The hog is then divided straight up the baek, and the sides are ready for salting, the ham still remaining in.

"When the sides are ready for salting, they are well rubbed on the rind side, and the spaee from whieh the shoulder-blade was taken ont is filled with salt. The sides are then laid singly upon a flagged floor, and salt is shaken over them. In a day, or two days if the weather be eold, they must again be salted in the same manner; but now two sides may be put together, and powdered saltpetre shaken over each side, in the proportion of about two ounees to each side, if of average baeon size. After three or four days, the sides are to be again ehanged, the shanks of the hams rubbed, the salt stirred on, a little fresh salt shaken over them, and five or six sides may now be placed over each other. The sides may then be left thus for a week, when they may be piled one over the other to the number of ten or twenty sides, if you have killed so nany hogs. Leave them so for above three weeks, until they get firm; they may then be eonsidered saved, and will keep so for six or eight inonths, or aeeording to pleasure.

"When required for use or for market, the sides are taken ont of the salt, well swept and eleaned-the ham taken out, hung up, and dried with turf smoke; if a brown eolor be desired, a little saw-dust of hard wood may be thrown over the turf. If hung up in a kitehen where turf is burned, and suffered to remain, not too near the fire, the same effeet will be produeed; and if the baeon have been well saved in salt, it will be exeellent.

"'lle Belfast and Limeriek methods of entting differ from what I have deseribed, inasmueh as the hip-bones are left in, and the hams are eut out, while the $\log$ is tresh, and saved separately. In some eases, also, the ribs are taken out of the sides, and, in Belfast, the shoulderblade is taken out over the side.

"Botll the Belfast and Limeriek hams are eured in the same mild manner; they are, as I have stated, eut out of the $\log$ when fresh, eured separately, and only left a suffieient time to be saved, and no more. They are not suffered to beeome too salty, a fault sometimes pereeptible in the Wieklow hams. The Limeriek and Belfast eurers also make up different other portions of the bog separately, as long sides, middles, and rolls, for the English market.

"Sometimes the ribs are taken out, and sometimes not, aeeording to the inarket for whieh they are intended.

"Limerick and Belfast hains are eured" in the following manuer :They are eut fresh from the pig, with the hip-bones left in them, and are plaeed on a flagged floor, the front of the second ham resting upon 
the shank of the first, and so until all are placed; they are then sprinkled with strong pickle from a watering pot, and a small quantity of salt is shaken over them. Next day, the hams are taken up, well rubbed with salt, and laid down as before, when saltpetre is shaken over them in quantities proportionate to their size; they are left so for two days, and then taken up and rubbed as beforc, when they are laid down again, according to the space they have to fill-from three to six hams in height, with layers of salt between. After six days, the lams are reversed in the piles, that is, those that were packed on the top are put at the bottom. They then remain for six days longer in the. pile, when they are considered cured. They are then taken up, and washed, and hung up to dry in the air. When they are to be smoked, thcy should be placed in a house made for that purposc, and smoked-in Belfast, withl wheaten straw and saw-dust, in Limerick with peat or turf.

"The English method of cutting up and curing is similar to that practiced in Bclfast and Limerick, with the difference that, with the exception of Hampshire and I believe one other county, they never smoke their bacon.

"We liave, this scason, had inported a great quantity of hams and other bacon from Cincinnati and Baltimore, in Amcrica. They are cut in the same manuer as the Timcrick, and are in much esteem. The curcd shoulders of the hog have also been imported-cut straight across, witl the blade in, and the shank left attached. We have also received middles, and quantities of pork, in barrels, which is merely the hog eut up in pieces, and pickled.

"I have reason to know that there are at the present time numbers of curers emigrating from our best cnring districts to America, and we may accordingly cxpect, ere long, to find our Amcrican hams surpassing, owing to the quality of the hogs they will have to operate upon, even our long-famed Limerick hams."

\section{LIVE-STOCK-NUMBER TO BE KEPT, ETC.}

The animals necessary for the stocking and cultivation of a farm, and those which are kept on it for profit, or for the sakc of their dung, are called tlıc live-stock of the farm, in contra-distinction to the dead-stock, which consists of the implements of husbandry and the produce stored up for use.

The live-stock on a farm must vary according to circumstances. The number of horses or oxen kept for the cultivation of the land and other farming operations shonld be exactly proportioned to the work to be donc. If they are too few, none of the operations will be performed in their proper time, and the crops will suffer in consequence. If there are too many, the surplus beyond what is strictly required is maintained out of the profits of the farm. To have the exact number of animals which will give the greatest profit is one of the most important problems which a farmer has to solve: what may be very profitable in one case may be the reverse in another; and, as a general maxim, it may be laid down, that the fewer moutlis he has to feed, unless they produce an evident profit, the less loss be is likely to incur. But this rule ad- 
mits of many exceptions. It is of great importance, in taking a farm, to calculate the extent of the arable land, so that it ean bc properly cultivated by a certain number of pairs of horses or oxen. It is an old mcasurc of land to divide it into so many plows, that is, so many portions which can be tilled with one plow each. When there are sevcral of these, it is useful to have an odd horse over the usual number required for two or threc plows, to relieve the others oceasionally. The work is thus done more regularly and with greater ease. Where there are two plows with two borses each, a fifth horse should be kept, and so in proportion for a greater number. The odd horse will always be found extremely useful, if not indispensable, and the expense of his keep will be amply repaid by the regularity and ease with which the whole work of the farm will be done, and the relief which oceasional rest will give to the other horses.

The other part of the live-stock kept on a farm must depend on various circumstanees. Where there is good grazing land, the profit on the improvement of the live-stock, or their produce, is evident and easily ascertained. But where animals are kept upon artificial food or fatted in stalls, it is often a difficult question to answer, whether there is a profit on their kecp or not. In most eases the manure which their dung and litter afford is the chief object for which they are kept. If manure could be obtained in sufficient quantitics to reeruit the land, at a reasonable price, it might often be more advantageous to scll off all the hay and straw of a farm, and to kecp only the cattle necessary to till the ground or supply the farmer's family. But this ean only be the case in the immediate neighborhood of large towns. In the country at a greater distance no manure can be purehased; it must conscquently be produced on the farm; and for this purpose live-stock must be kept, even at a loss. The management and feeding of live-stoek is therefore an important part of husbandry. The object of the farmer is prinejpally to obtain manure for his land, and if he ean do this, and at the same time gain something on the stock by which it is obtained, he greatly increases his profits. Hence mueh more skill has been displayed in the selection of profitable stock than in the improvement of tillige. Some men have made great profits by improving the breed of cattle and slicep, by seleeting the animals which will fatten most readily, and by feeding them ceonomically. It requires mneh experience and nice caleulations to aseertain what stock is most profitable on different kinds of land and in varions situations. Unless very minute accounts be kept, the result can never be cxactly known. It is not always the bcast which brings most moncy in the market that has bcen most profitable; and many an animal which has been praised and admired has caused a heavy loss to the fecder. Unless a man breeds the animals which are to be fatted, he must frequently buy and sell; and an accurate knowledge of the qualities of live-stoek and their value, both lean and fat, is indispensable. However honest may be the salesman he may employ, he cannot expect him to fecl the same interest in a purchasc or sale, for which he is paid his commission, as the person whose profit or loss depends on a judicious selection and a good bargain. Every farmer therefore should endeavor to acquire a thorough knowl- 
edge of stock, and carefully attcnd all markcts within his reach to watch the fluctuation in the prices. It will generally be found that the principal profit in feeding stock is the manurc, and to this the greatest attention should be directed. A little management will often greatly increase both the quantity and quality of this indispensable substancc, and make all the difference between a loss and a profit in the keeping of stock.

TIIE "CREAM-POT" BREED OF CATTLE.-This is a valuable dairy-breed and promises to exceed all other brecds in this country, in the quantity and richness of the milk it furnishes, and the extraordinary amount of butter which it yields. This breed originated in Ncw England, and was produced by Col. Jaques, of Ten Hills Farm, Somerville, Mass., by crossing the improved short-horns with the most valuable native breed. Col. Jaques thus spcaks of the origin of this brecd:- "Hearing of cows that produce seventeen pounds of butter each per week, the inquiry arose, why not producc a breed of such cows that may be depended on? This I attempted, and have accomplished. I have madc from one of my Crean-Pot cows nine pounds of buttcr in three days on grass fecd only.

"The bull Cœlebs, an imported thorough-bred Durham, and Flora, a heifer of the same breed, and imported, and a native cow, whose pedigrec is entirely unknown, comprise the elements of the Cream-Pot breed of cattle. The native cow was bought in consequence of her superior quality as a milkcr, giving cighteen quarts a day, and averaging about fiftecn. In the month of April, the cream of two days' milk produced two and threc-fourths pounds of butter, made of two and onc-sixtecnth quarts of cream, and required bnt two minutes' churning. 'Thus much for the mother of the Cream-Pots.

"I have bred my Crcam-Pots with red or mahogany-colorcd liair and teats, and gold-dust in the cars, yellow noses and skin, the latter silky and elastic to the touch, being like a fourteen-dollar cloth. My CreamPots are full in the body, chops deep in the flank, not quite as straight in the belly, nor as full in the twist, nor quite as thick in the thigh as the Durhams; but in other respects like them. They excel in affording a great quantity of rich crcam, capable of bcing converted into butter in a short time, with little labor, and with a very small proportion of buttermilk, the cream producing more than eiglity per cent. of butter. I have changed the creain to butter not unfrequently in one minutc, and it has becn done in forty scconds."

Henry Colman thus refers to Col. Jaques's stock:- "Mr. Jaques is entitled to great credit for his carc and judicious selection in continuing and improving his stock. I have repeatedly secn the eream from his cows, and its yellowness and consistency are remarkablc, and in company with several gentlemen of the Legislaturc, I saw a portion of it converted to butter with a spoon in one minute. The color of Mr. Jaques's stock is a decp red, a favorite color in New England; they are well formed and thrifty on common feed ; and if they continuc to display the cxtraordinary properties by which they are now so distinguished, they promise 
to prove the most valuable race of animals ever known among us for dairy purposes, and equal to any of which we have any information."

TO ESTIHATE TIIE LIVE WEIGHT OF CATTLE, etc.-Drovers and butchers by long experience bccome very expert in cstimating, by simple inspection, the weight of live cattle; and in making purchases, they thus have a decided advantage over the less experienced scller. Hence, the importance to the latter of some means by which he can know, and not guess at the weight of his live animals.

The following rules, the result of careful experiments, and which we take from The Valley Farmer, will enable any one to ascertain the weight of live animals with a close approach to accuracy:-take a string, put it around the breast, stand square just behind the shoulderblade, mcasure on a rule the fcet and inches the animal is in circumference; this is called the girth; then, with the string, mcasure from the bone of the tail which plumbs the line with the hinder part of the buttock; dircet the line along the back to the fore part of the shoulderblade; take the dimensions on the foot-rule as beforc, which is the length; and work the figures in the following manner:-girth of the animal, say six feet four inches, length fire fect three inches, which multiplicd together, makes thirty-one squarc superficial fect, and that multiplied by twenty-three, the number of pounds allowed to each superficial foot of eattle incasuring less than seven and more than five feet in girth, makes seven hundred and thirtcen pounds. When the animal measures less then nine and more than seven fect in girth, thirty-one is the number of pounds to each superficial foot. Again, suppose a pig or any small benst should measure two fect in girth and two along the back, which multiplied together makes four square fect, that multiplicd by elcven, the number of pounds allowed to cach square foot of cattle measuring less than three fect in girth, inakes forty-four pounds. Again, suppose a calf, a shcep, etc, should mcasurc four fect six inches in girth, and three feet nine inches in length, which multiplicd together make fiftecn and a quarter square fect; that multiplicd by sixteen, the number of pounds allowed to cattlc measuring less than five fect and more than three in girth, makes two hundred and sixty-five pounds. The dimensions of girth and length of horned cattle, sheep, calves, and hogs, may be exactly taken in this way, as it is all that is neccssary for any computation, or any valuation of stock, and will answer exactly to the four quarters, sinking offal.

11 



\section{DOMESTIC POULTRY:}

THEIR

BREEDS AND TREATMENT

IN

HEALTH A D DISEASE. 


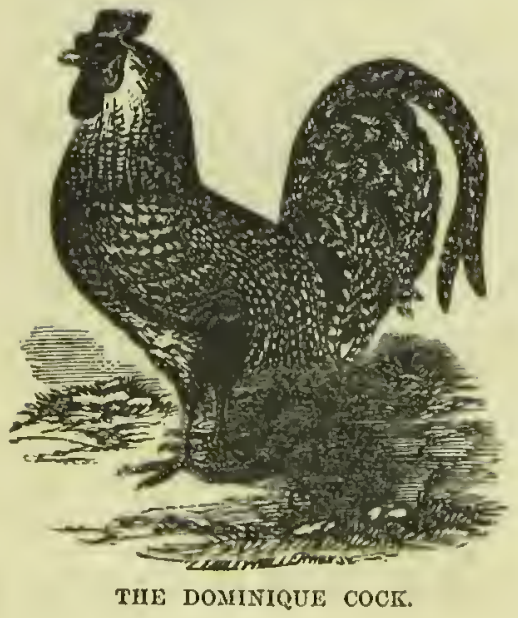




\title{
DONESTIC POULTRY.
}

\author{
"How grateful 'tis to wake \\ While raves the midnight storm, and hear the sound \\ Of busy grinders at the well-filled rack; \\ Or flapping wing or crow of chanticleer, \\ Long ere the lingering morn; or bouncing flails \\ That tell the dawn is near! Pleasant the path \\ By sunny garden wall, when all the fields \\ Are chill and comfortless; or barn-yard snug. \\ Where flocking birds, of various plume and chirp \\ Discordant, cluster on the leaning stack \\ From whence the thresher draws the rustling sheaves."
}

VIEW OF THE IMPORTANCE OF TIIE SUBJECT,-Poultry-keeping is an amusement in which every body may indulge. The space needed is not great, the eost of food for a few head insignifieant, and the lnxury of fresh eggs or home-fatted eliekens or dueks not to be despised. In a large eollection of poultry may be read the geography and progress of the eommeree of the world. The peacock represents India; the golden pheasant and a tribe of dueks, China; the turkey, pride of the yard and the table, America; the black swan, rival of the snowy monareh of the lakes, reminds us of Australian diseoveries; while Canada and Egypt have each their goose. The large fat white dueks-models of what a duek should be-are English, while the shining green black ones eome from Buenos Ayres. And when we turn to the fowl varieties, Spain and Hamburg, Poland and Cochin China, Friesland and Bantam, Java and Negroland, beside Surry, Sussex, Kent, Suffolk, and Laneashire, have each a coek to erow for them.

VARIETIES OF THE DOMESTIC FOWL, - The MaLay Fow from its size and strength, is admirably adapted for erossing with the Dorking and other native breeds. 2. The JAva Fow nearly resembling, and in the opinion of some, identieal with, the Nalay. 3. The Cocurs China breed, equal in most respeets, and more prolifie than the Malay. 4. The Spanisir Fow , perhaps the best breed known for laying. 5 . The Pousn Fows, a noble and very beautiful bird, and an excellent layer. 6. The Spangled Vameties, ineluding the whole elass of Gold and Silver Spangled, known in different conntries as Spangled Hamburgs, Every-day Dutch, Bolton Bays, Bolton Greys, Chittyprats, Creoles, Corals, ete. 7. The Speck Led and Wnite Dorking, the most delieate of all the varieties for the table. 8. The Sussex Fowl, most probably a variety of the Dorking. 9. The GaMe Fow graeeful of form and plumage, with undying courage, and excellent for erossing with eommon varieties. 10. The PHeAsant Fowl, erroneously said to originate in a eross with the Coek Pheasant. 11. The Bantams, more remarkable for their beauty than any other quality.

The Malay Fowl, ealled also the Chittagong,-This is a large and heavy fowl; it is a close and hard-feathered bird, from which eireumstance it 
often weighs more than it appears to do. It stands tall, with very upright gait. The legs are long, the thighs are remarkably long, strong, and firm; and the tarsi of moderate length, round, stout, and of a yellow eolor. The tail is long and drooping, the head snake-shaped, $i . e$, with a great fullness over the eyc, and of a flattened form above. The thiek comb, scarcely rising from the head, has been compared to half a strawberry; so that the natural form of comb a little resembles that of the game-fowl when dubbed. The neck is rope-like and closefeathered, and the bird is almost without wattle.

The Malay should have a pcarl eye, and a hawk bill free from stain.

The pullets commenee laying early, and are often good winter layers. The egg is of mcdium size, with a tinted shcll. The chickens when half-grown, are gaunt, ungainly looking young things, and, like many choice kinds, fledge slowly.

Height is a great point in a Malay. Old fanciers had a curious modc of eomparing notes upon this point. They used to hold the bird out at full stretch, and measure the length, from beak to toe, on a table. Some of old Mr. Castang's breed are mentioned as having measured thirty-eight and a half inches. The coeks are said to have wcighed from nine and a laalf pounds to eleven pounds, and the hens from eight pounds to ten pounds.

I have known a Spanish cock and a Malay hen produce exeellent fowls for the table, being large, fleshy, and well-flavored.

The Malays are inveterate fighters; and this is the quality for which they are chiefly prized in their native country, where eock-fighting is carried to the extent of excessive gambling. Men and boys may be frequently met, cach earrying his favoritc bird under his arm, ready to set to work the moment the opportunity shall cccur.

The Cochin China.-The history of the Coehin-China fowl might be the history of the poultry mania, an excitement which rivaled manias of greater importance in its strength. They were introduced some time about the year 1845 , and soon bccame known and popular. Their large size, in the eyes of most persons, their handsome appearance, the briglitness of their colors, the number of thcir eggs, and their gentle, quiet disposition, soon made their way; they were much liked, and were bought eagerly at from three to six dollars each; at that time a very high price for a fowl. Cochin China hens arc excellent layers of mcdium-sized eggs, which they produce in great abundance at the season when they are of greatest valuc. The ehickens, if bred from mature birds, are exceedingly hardy ; and the fowls are of quiet, domestie habits, and easily kept within bounds. A first-class fowl should be compaet, large, and square-built; full in the chest, deep in the keel, and broad across the loins and hind quartcrs. The best in form are as compactly made as Dorkings. The head is delieately shaped, with a short bill, and the eomb fine in tcxture, rather sinall, perfectly single, straight, and equally serratcd; the wings sinall and elosely folded in, the tail short, and carried rather horizontally; the legs very short, ycllow (aceording to rule) and hearily feathered. This fowl has, however, lost its carlier popularity, and is now generally discarled by good poulterers, being found a voracious feeder, and yielding a comparatively small return for the food eonsumed. 


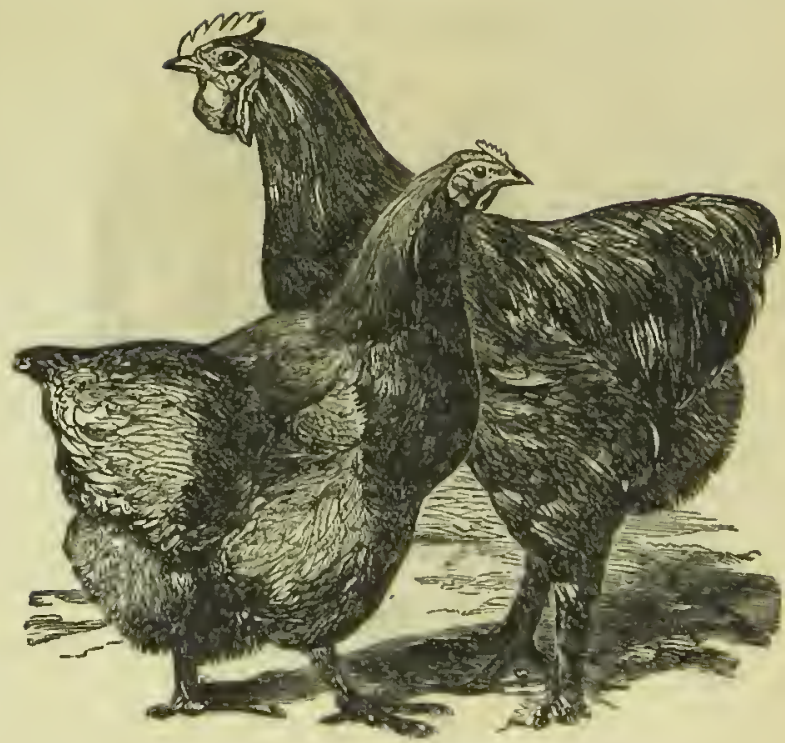

COCHK CLINA, OR BHAXEIIAI FOWL.

Spanish Fowls. - The elief drawbacks in rearing Spanish are the delicacy of the chickens while young, and the length of time which elapses beforc the youngsters show their quality, unless they are bred from much better fowls than most persons can command; in which case the chickens develop their prize properties carlicr. The combs of the hens shrink very much when they are not laying, and during the moulting season. In winter they should be protected from severe cold, which is very apt to scize the comb and wattles of the cocks.

The hens lay larger eggs than any other kind of fowl we have : they are non-sittcrs. The chickens hatch ont black, with a little mixture of dull white, or yellow. They fledge slowly, and are very delicate while young.

The Minorca.-This is a plump-bodied, useful fowl, which would be a Spanish, if it could persuade its parcnts to bequeath it the white face which breeders and judges think so much of. The plumage is black, with metallic luster, and the hens lay fine large cggs. I believe they sit more than the Spanish.

The White Spanish.-The white-faecd white Spanish I believe to be merely a sport of the white-faced black Spanish. The red-faced white Spanish, or white Andalusian, is rcally a Spanish fowl. They are good layers, and very precocions. Thic stoek was brought from Spain.

Andalusian Fowls. - The birds which have been shown under this name are in color the kind of gray called blue, which is sonctimes laced and shaded with blaek. Mr. Taylor, late of Shepherd's Bush, imported the original stock from Spain. They are good-looking fowls with large pendent scarlet combs like the Spanish, and are said to be good layers. 


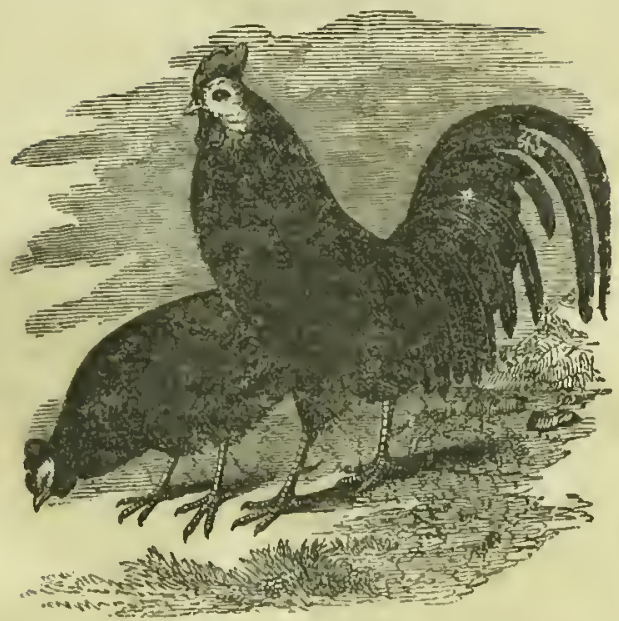

THR BPANIBI FOWI.

Polands.-With these fowls there has been much difference of opinion respecting thc applicability of the name. Some, with apparent reason. would divide them into three familics; the St. Jago, the Turkish, and

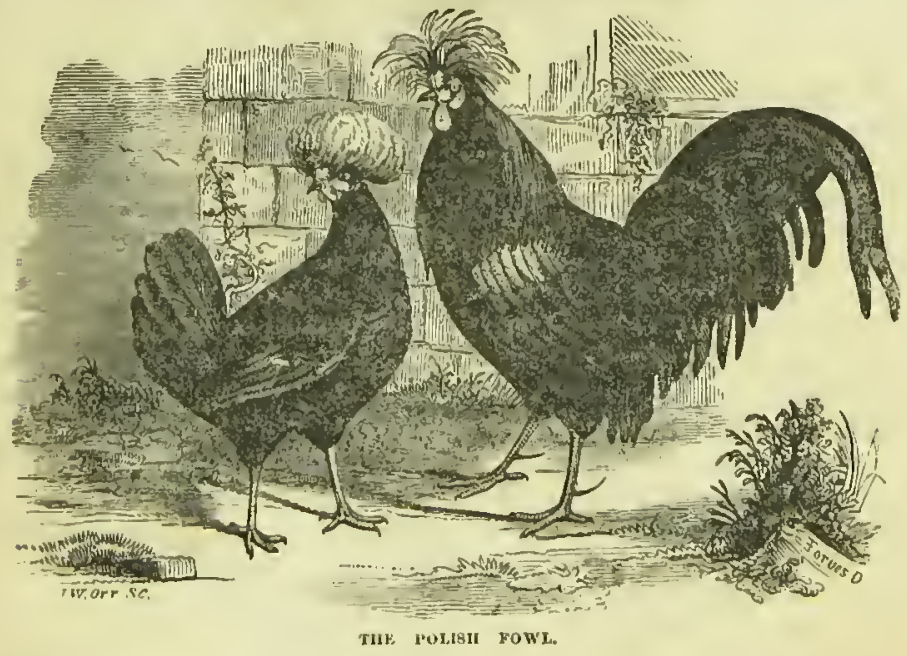

the Hamburg, or muffed kind. We rank as Polands all fowls with their chicf distinguishing eharacteristic - a full, largc, round, eompaet tuft on the head. It is a class of fowls, the bcanty of which, united to their useful qualities, must make general favorites. All the sub-varicties are of mediun size, neat compact form, witl full plump bodics, full breast, lead-eolored legs, and ample tails. The kinds more or less known are very numerous: they are all good layers. 
The White-crested Black Poland is a fowl of a deep relvety black, with a large white tuft on the head. They should be without eomb; but many have a little comb in the form of two small points beforc the tuft. The tuft, to be perfect, should be entirely white; but it is rare to meet with one without a slight bordering of black, or partly black feathers round the front.

The Golden and Silver Polands are, the one a gold eolor, the other white spangled with black: the tuft, as in the black, should be large and compact. The more completely the color in the tuft can partake of the character of feather in the rest of the bird, the better. Some persons admit white in the tuft of the golden Poland, but I eannot help thinking the mixture a great fault. Mr. Baily (well known as one of the best judges) would like to see the feathers of the tuft laced. This is very difficult of attainment. The marking of the bird is a black spangle on the golden or silver ground-eolor. The wings are barred, and the best judges admit lacing on the wing-coverts.

There are several other varieties of tufted fowls or Polands, and many intelligent breeders have devoted great attention to them.

The blaek and the white are both beautiful, with full tufts, muffs, and elean legs.

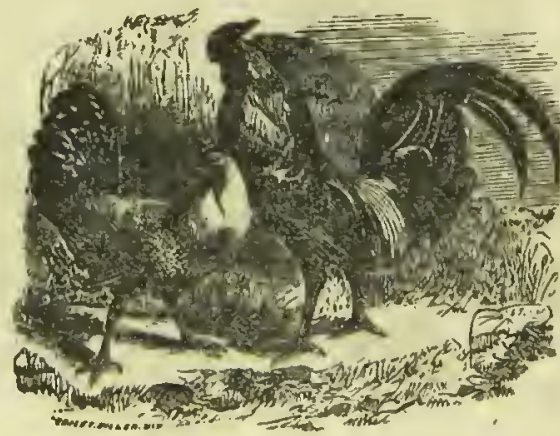

THE GOLDEN SPANGLED HAMBURO FOWL.

Hamburg Fowls, -The Iamburg is a medium-sized fowl, with a brisk and spirited bearing, a brilliantly red donble comb, ending in a spike at the back, taper blue legs, ample tail, exact markings, and a well developed white deaf ear. They are profitable fowls to keep, being excellent layers, and not large eaters. They are what pigeon-faneiers would call good field-birds, delighting to wander far abroad, and to seek provender for themselves. The varieties are,

The Spangled Hamburg, or plieasant-fowls, the marking of whieh takes the form of a spot upon each feather. They are divided into grold and silver, aceording to the ground-color of the plunnage.

The Penciled IIamburg, in which the marking is more minute. When seen at a distanee, the hens have the appearance of being minutely speckled in plumage, and over this a pure white hackle falls and contrasts very prettily. When one feather is taken separately, the marking is very exact and besutiful, being a regular peneiling; i.e., the 
feather is divided by bars evenly arranged, of alternatc white and gold color. Like the spangled, they are divided into golden and silver for the same reason-the ground-color of the plumagc. In all these birds, exactness of the markings is a great point.

The Black Ilamburg. - This is a very bcautiful varicty, being of a brilliant black, with metallic luster. The brilliancy of the plumage, contrasted with the coral-red of the spiked comb and the whitc carlobes, renders this fowl so attractive in appcarance, that we cannot help wondering that it is not morc gencral, particularly as, likc all the Hamburgs, it is an exccllent laycr.

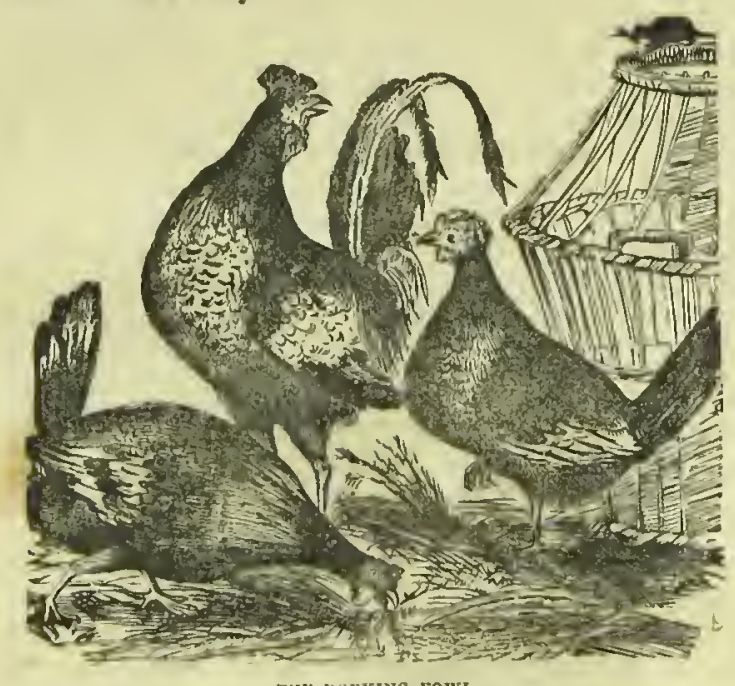

THL DORKING FOWL.

The Dorking Fowl.-The Dorking would appear to owe its name to its having been chicfly bred in a town of Surry, of the samc appcllation. That the peculiarity of five toes, or, in other words, of two hind tocs instead of one, is to be regarcied as a distinctive character of the breed, is by some writers questioncd, and by others wholly denied. For my part, I should say, that whencver this characteristic is absent, a cross has been at work.

I do not, however, mean to assert that this possession of two hind toes instead of one, has never occurred in any other fanily of fowl cxcept those bred at Dorking, in Surry, for Aristotle has incntioned the existence of a similar peculiarity anong certain fowl in Grecec, and both Columella and Pling assert the existence of such in their time in Italy, so also does Aldrovand; and these authors lived hundreds of ycars ago; and, oddly enougl, these brecds were remarkable, as arc our own Dorking, for being good layers and good sitters.

The color of the Dorking is usually pure whitc, or spotted or spangled with black; thesc eolors sometimes merge into a gray or grizzle. The hens wcigh from seven to nine ponnds; stand low on their legs; 
are round, plump, and short in the body; wide on the breast, with abundanee of white juicy flesh. The hens are generally good layers, and their eggs, though smaller than the egg of the Spanish and Polish breeds, are of good size and well flavored. These birds have been long prized, and it is now many years sinee their superiority over our ordinary domestie varieties was originally diseovered and appreeiated; they were first noticed, and the variety adopted, by the Cumberland breeders, whence they were soon brought into Laneashire and Westmoreland, and gradually spread over all England. Whether, however, from injudicious treatment, or imperfect feeding, or ehange of elimate, or from whatever eause, it is certain that, when met with far from their native place, they appear greatly to have degenerated from their original superiority of eharacter. In this, and all other varieties of fowl, fresh blood should be introduced from time to time, or the breed degenerates.

The best breed of the gallinaceous fowls is the produce of the Dorking (Surry) eock and the eommon dunghill fowl. This eross is larger and plumper, and more hardy than the pure Dorking, without losing delieaey of flavor or whiteness of flesh.

The eharacteristies of the pure Dorking are, that it is white-feathered, short-legged, and an excellent layer. The peeuliarity of this established variety, which has frequently five elaws perfectly artieulated (with sometimes a sixth springing laterally from the fifth, but always imperfeet), is well known. The erossing with the Sussex fowl has however greatly diminished the monstrosity in the Surry pentadactylus variety. But though the true Dorking, which is white, is mueh esteemed, that eolor is rare, and prized for the ornament of the poultry-yard; speekled eolors are most generally seen with the higgler.

The Sussex.-This is but an improved variety of Dorking, similar in shape and general eharacter, usually of a brown color, but possessing the advantage of wanting the fiftl toe; we say adrantage, for the Dorking fowl frequently beeomes diseased in the feet, the cocks espeeially, in eonsequence of breaking the supplementary toe in fighting.

The Game Fowl.-The game fowl is one of the most graeefully-formed and most beautifully eolored of our domestie breeds of poultry; in its form and aspect, and in the extraordinary eourage whieh eharacterizes its natural disposition, it exhibits all that either the naturalist or the sportsman recognizes as the bcau ideal of high blood, embodying, in short, all the most indubitable eharaeteristies of gallinaceous aristocracy.

We do not possess any very satisfactory reeord of the original eountry of the game fowl; but we are disposed to eede that honor to India, the natives of which eountry have always been renarkable for their lore of eock-fighting; and we also know that there still exists in India an original variety of game eock, ver'y similar to our own, but inferior in point of size. As to the date or oceasion of their first introduction into the British islands, we know nothing eertain; but it is probable that we owe it to the invasion of Julius Cresar, the Romans having been very fond of the sport of eoek-fighting.

It is not only for its pugnacious qualities that the game fowl is to be noticed; it yields to no breed, nay, perhaps is superior to most, in the 


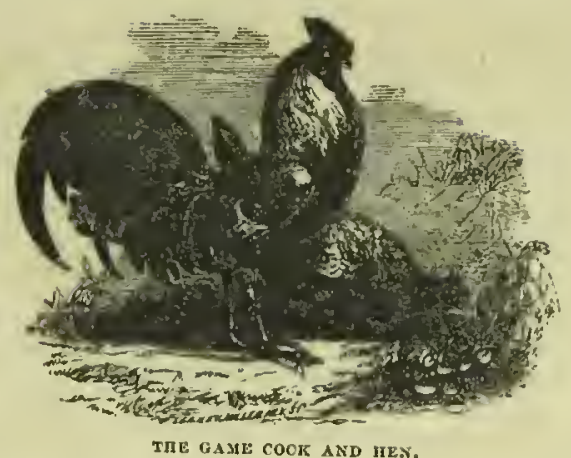

whiteness and sapidity of its flesh; the hens are excellent layers, and the eggs, though of moderate size only, are remarkable for the delicacy of their flavor. The game coek is very attentive to his fcmalc train, and ever ready to do bartlc in their defense; but not unfrequently he becomes savage and dangerous. A blow with his spur is no trifle. Children have becn severcly injured, and eases have bcen mentioned in which they have been killed. From thcse eauses, and from the fact that the young broods, as soon as fairly fcathercd, begin to fight among themselves with desperate determination, blinding each other, stripping the skin from each otlier's heads and neelis, and killing each otlier on the spot, many persons object to kecp this breed; and it must be confessed that it occasions grcat trouble; it is not al ways convenient or possible to separate the young broods; and as the young coeks and hens fight indiscriminately, it not unfrequently happens that one-half is destroycd in the mêlée, while nost of the survivors are so mangled as to render it necessary to put them out of pain, to the mortifieation of the farmer or breeder of towls for profit; for not only are the broods lost,
but the time also.

Of all brceds, the game breed is the most bcautiful, whether we look to contour or coloring; the game cock carries limself proudly, and yet gracefully; his port and bearing proclaim his fiery spirit and undaunted mettlc, which cndure cren to his last breath; for while prostrate and mortally wounded, he will answer the insulting erow of his vietorious rival, and make a last effort to revenge himsclf bcfore the spark of life is extinct. No wonder that the gallant coek sbould have been ehosen as the emblem of courage.

Bantams. - The classes of Bantams are gold-laced, silver-laced, white, black, and one for "any other variety;" from which last may especially be scleeted the exceedingly beautiful game Bantams, and the once popular, but now rarc, booted sub-varicty. Diminutive size and bold carriago are inportant points in all Bantams; in other respects, the different kinds differ as much as distinet varietics of fowls can do. The Bantams arc peeuliarly fancy fowls; thcy have becn aeeused of not being a useful kind, as of course there is little to eat in a fowl which, when full grown, should weigh, the eock about a pound, the ben less, the eggs 


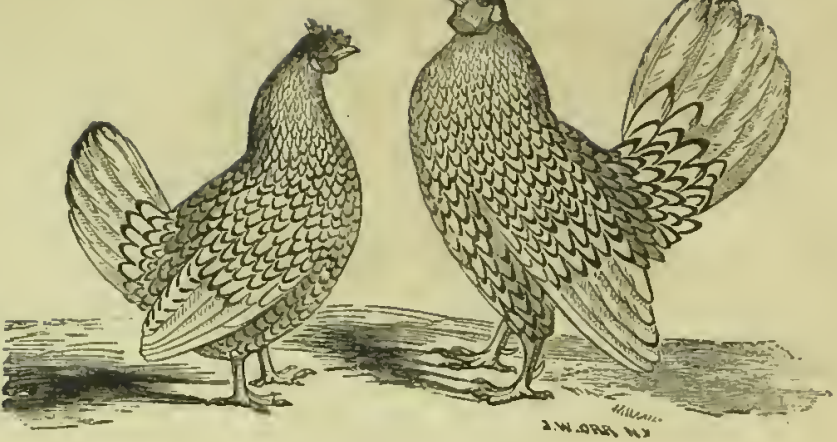

THE BEABRIGITT BAKTAY.

being sinall in proportion. But how many hundreds of amateurs there are whose opportmnitics give them no room for full-sized fowls, but who, delighting in living things, can indulge their fancy and beguile many

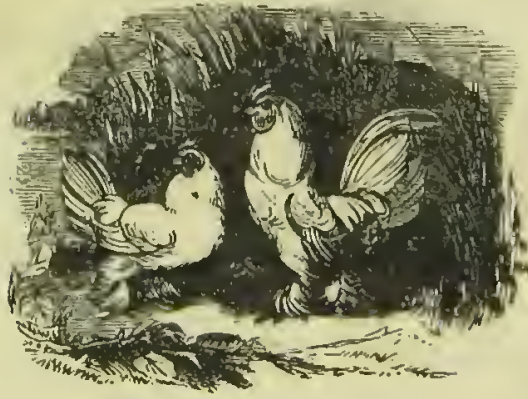

WHTL BAXTAY COCK AND HEN. hours which would otherwise prove weary ones, by kecping a few Bantans. Their small cggs are delicacics which would tempt almost any invalid.

The gold and silver-laced, or Seabright Bantam, is perhaps the most popular kind of all The size should be quite diminutive, and the carriage sancy.

The booted Bantam, of which. the most beautiful we have seen have bcen pure whitc, are complctely fcathered on the lcgsnot feathered down one side only, like the Cochin China.

Game Bantams are cxact miniature representatives of game fowls,

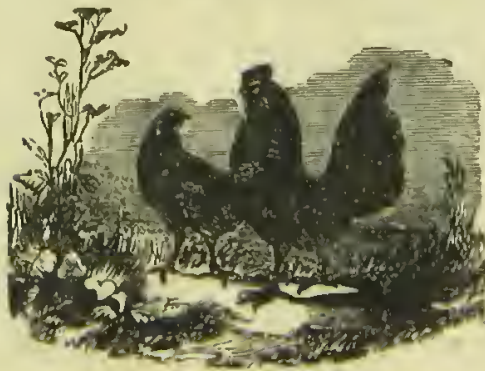

BLAOK RAXIAK COCK AXD HEN. black-brcasted reds, duck-wings, and other colors. An exact duck: wing game Bantam is the most beautiful little creature one can innaginc.

THE DOIESTIC TURKEY.-The domestic turkey can scarecly be said to be divided, like the common fowl, into distinct breeds, although there is, indecd, considerable variation in color, and also in size. The finest and strongest turkcys arc said to be those of a bronzed black, resembling as closely as possible the original stock; thcy 
are reared the inost easily, are large, and fatten rapidly. Some turkeys are of a eoppery tint, others of a delieate fawn-eolor, others particolored, gray, and white, and some few of a pure snowy white. All these are eonsidered inferior to the black; their eolor indieates something like degeneraey of eonstitution, and they are seldom very large-sized.

In the ehoiee of store-birds some eare is requisite; the stoek should be of a good sort; the blaek Norfolk raee is an exeellent sort, probably produeed originally by a eross with the wild breed of Aineriea.

Early in spring, generally speaking, the female eommenees laying; she indieates her intention by a peenliar ery, by strutting about with an air of self-satisfaetion, and often by prying into out-of-the-way plaees. She should now be elosely watehed, and some management is required to induee her to lay in the plaee desired.

The nest shonld be prepared of straw and dried leaves; it should be seeluded; and to exeite her to adopt it, an egg, or a pieee of ehalk eut into the form of an egg, should be plaeed in it. When her uneasiness to lay is evident, and symptoms prove that she is ready, she should be eonfined in the shed, barn, or plaee in whieh her nest (in a large wieker basket) is prepared, and let out as soon as the egg is laid. It is generally in the morning that the turkey-hen lays, and mostly every other day, though some lay daily, until the number of eggs amounts to from fifteen to twenty. As the eggs are laid, it is as well to remove them (leaving the deeoy egg or pieee of ehalk) until the number is eomplete; as they are liable to be broken, or to be sueked by rats or weasels. They may then be restored to her for ineubation. The turkey-hen is a steady sitter, and in this respeet resembles the wild bird; nothing will induee her to leave her nest; indeed, she often requires to be removed to her food, so overpowering is lier instinetive affeetion. She must be freely supplied with water within her reach; should she lay any eggs after she has eommeneed ineubation, these should be removed: it is proper, therefore, to mark those which were given to her to sit upon. The hen should on no aceount be rashly disturbed; no one exeept the person to whom she is aeeustomed, and from whom she reeeives her food, should be allowed to go near her, and the eggs, unless eireumstanees imperntively require it, should not be meddled with.

On the twenty-sixth dav, aeeording to some on whom dependenee may be plaeed (the thirty-first aeeording to others), the ehieks leave the eggs.

The treatment of the eliek now requires attention. As in the ease of young fowls, the turkey ehieks do not require food for several hours. It is useless to eram them, as some do, fearing lest they should starve; and besides, the beak is as yet so tender that it runs a ehanee of being injured by the proeess. When the elieks feel an inelination for food, nature direets them how to piek it up. There is no oeeasion for alarm, if for many hours they eontent themselves with the warmth of their parent, and enjoy her eare only. Yet some food must be provided for them, and this should be, of course, suited to their nature and appetite. Here, too, let the simplieity of nature be a guide. We say this, beeause some have reeommended spiees, wine, and even bathing in eold water.

The first diet offered to turkey ehieks should eonsist of eggs boiled 
hard and finely mineed, or eurd with bread erumbs, boiled nettles, and the green part of ouions, parsley, ete., chopped very small, and mixed together, so as to form a loose erimbly paste. Barley or oatmeal, kneaded with a little water, and mixed with the pulp of potatoes and Swedish turnips, to whieh ehopped bect-leaves are added, may also be given. They will require water; but this should be put into very shallow vessels, so as to insure against the danger of the ehieks getting wet. Fresh milk is apt to disagree with the young birds, and is not needful. Both the turkey-hen and her ehiekens should be housed for a few days; they may then, if the weather be fine, be allowed a few hours' liberty during the day; but should a shower threaten, they must be put immediately under shelter. This system must be persevered in for three or four weeks. By this time they will have aequired considerable strength, and will know how to take eare of themselves. On the first drops of a shower, they will run for shelter into their aeeustomed plaee of refuge, which should be warm and waterproof. As they get older, meal and grain may be given them more freely. They now begin to searel for inseets, and to dust their growing plumage in the sand. $\Lambda t$ the age of about two months, or perhaps a little more, the males and females begin to develop their distinetive eharaeteristies. In the young males the earunenlated skin of the neck and throat, and the horn-like eontraetile eomb on the forehead, assumo a marked eliaraeter. This is a eritieal period. The system requires a full supply of nutriment, and good housing at night is essential. Some recommend that a few grains of eayenne pepper, or a little bruised hempseed, be mixed with their food. The distinetive scxnal marks onec fairly established, the young birds lose their names of chicks or chichens, and are termed turkey poults. The time of danger is over, and they beeome independent, and every day stronger and inore hardy. They now fare as the rest of the floek, on good and suffieient food, if their keeper is alive to his own interest. I again repeat it, that a man who kecps poultry on meagre, spare, innutritious diet, will never rear fine poultry, and never repay himself even for his niggardly outlay. Poultry shonld never bo in bad eondition : let them not be kept at all, unless they are kept properly.

TIIE WILD TURHEX is a noble bird, far exeeding its domestic relative in neatness of form and beauty. Crosses in Ameriea often take plaee between the wild and tame raees, and are highly valued, both for external qualities and for the table. In distriets where the wild turkey is eolunion, sneh crosses are quite freqnent; the wild male driving away his domestieated rival, and usurping the sultanship of the seraglio. Eggs of the wild turkey have frequently been taken from their nests, and hatelied under the tame hen. The young preserve a portion of their nneivilized nature, and exhibit some knowledge of the differenee between themselves and their foster-mother, roosting apart from the tame ones, and in other respeets showing the foree of hereditary disposition. The domestieated young reared from the eggs of the wild turkey are often employed as deeoy-birds to those in a state of nature. Mr. William Bloom, of Clearfield, Pennsylvania, eanght five or six wild turkeys when quite ehiekens, and sueceeded in rearing them. Although sufticiently taine to feed with his tame turkeys, and generally associate with them, 
yet they always retained some of their original propensities, roosting by themselves, and higher than the tame birds, generally on the top of some tree, or on the house. They were also more readily alarmed. On the approael of a dog they would fly off, and seek safety in the woods. On an occasion of this kind, one of them flew across the Susquelianna, and the owner was apprehensive of losing it. In order to reeover it, he sent a boy with a tame turkey, which was released at the place where the fugitive had alighted. This plan was successful. They soon joined eompany, and the tame bird induced his companion to return home. Mr. Bloom found occasion to remark that the wild turkey will thrive more and keep in bettcr condition than the tame turkey, on the same quantity of food.

The native country of the wild turkey extends from the northwestern territory of the United States to the Isthmus of Panama, south of which it is not to be found, notwithstanding the statements of authors, who have mistaken the curassow for it. In Canada, and the now denselypeopled parts of the United States, wild turkeys were formerly very abundant, but, like the Indian buffalo, they have been eompelled to yield to the destructive ingenuity of the white settlers, often wantonly exercised, and seek refuge in the remotest parts of the interior. Although they relinquish their native soil with slow and reluctant steps, yet sueh is the rapidity with whieh settlements are extended, and condensed over the surface of this country, that we unay antieipate a day, at no distant period, when the hunter will seek the wild turkey in vain.

The wooded part of Arkansas, Louisiana, Tennessee, and Alabama; the unsettled portions of the statcs of Ohio, Kentucky, Indiana, and Illinois; the vast expanse of territory northwest of these states, on the Mississippi and Missouri, as far as the forests extend, are more supplied than any other parts of the Union with this valuab!e gane, whieh forms an important part of the subsistence of the humter and traveler in the wilderness. It is not probable that the range of this bird extends to or beyond the Roeky Mountains. The Mandan Indians, who a few years ago visited the city of Washington, considered the turkey one of the greatest curiosities they had seen, and prepared a skin of one to carry home for exhibition.

In Florida, Georgia, and the Carolinas, the wild turkey is not common, and still less so in the western parts of Virginia and Pennsylvania. Some, however, are said to exist in the mountainous districts of Sussex county, New Jersey.

The wild turkey is irregularly migratory, as well as irregularly gregarious. Whenever the forest fruits (or mast) of one portion of the country greatly exeeed those of another, thither are the turkeys insensibly led, by gradually meeting in their haunts with more fruit, the nearer they advance toward the place in which it is most plentiful. Thus, in an irregular manner, flock follows flock, until some districts are deserted, while others are crowded with an influx of arrivals. "About the beginning of October," say's Audubon, "wlien seareely any of the seeds and fruits have fallen from the trces, these birds assemble in floeks, and gradually move toward the rich bottom-lands of the Olio and Mississippi. The males, or, as they are more commonly called, tho gobblers, associato 
in parties of from ten to a hundred, and seareh for food apart from the females; while the latter are seen either advaneing singly, each with her brood of young, then about two-thirds grown, or in union with other families, forming parties, often amonnting to seventy or eighty individuals, all intent on shunning the old eocks, which, when the young birds have attained this size, will fight with and often destroy them by repeated blows on the head. Old and young, however, all move in the same course, and on foot, mnless their progress is interrupted by a river, or the hunter's dog force them to take wing.

"When they eome mpon a river, they betake themselves to the highest eminences, and there remain often a whole day, and sometimes two, as if for the purpose of consultation. During this time the males are lieard gobbling, calling, and making much ado, and are scen strutting about, as if to raise their eourage to a piteh befitting the emergeney. Even the females and young assume something of the same pompous demeanor, spread out their tails, and run round each other, purring loudly, and performing extravagant leaps. At length, when the weather appears settled, and all around is quiet, the whole party mount to the tops of the highest trees, whenee at a signal, consisting of a single eluek, given by a leader, the flock takes flight to the opposite shore. The old and fat birds easily get over, even should the river be a mile in breadth, but the younger and less robnst frequently fall into the water-not to be drowned, however, as might be imagined; they bring their wings elnso to their bodies, spread out their tails as a support, stretel forward their necks, and striking out their legs with great vigor, proceed rapidly toward the shore; on approaching which, should they find it too steep for landing, they cease their exertions for a few moments, float down the stream till they come to an accessible part, and by a violent effort generally extricate themselves from the water. It is remarkable that, inmediately after erossing a large stream, they ramble abont for some time as if bewildered. In this state they fall an easy prey to the hunter.

"When the turkeys arrive in parts where the mast is abundant, they separate into smaller flocks, composed of birds of all ages and both sexes, promisenonsly mingled, and devour all before them. This happens about the middle of November. So gentle do they sometimes become after these long journeys, that they have been seen to approach the farm-honses, assoeiate with the domestie fowls, and enter the stables and corn-cribs in quest of food. In this way, roaming about the forests, and feeding ehiefly on mast, they pass the antmmn, and part of the winter."

The season of conrtship begins abont the middle of February. The femain anow separate from the males, whom they endeavor to shun, hut by whom they are perseveringly followed.

It is generally about the middle of $A$ pril that the female begins to select a site, aud arrange her rude nest, which eonsists ehiefly of withered leaves, in some depression on the gromnd, amidst dense brusliwood, or in such an obscure place as the locality affords. The eggs, like those of the domestic bird, are of large size, and of a dull cream-white, minntely freekled or dotted with reddish-brown; their avernge nmulher 
varies from ten to fifteen. While the gradual addition of cgg to egg is going on, the hen displays surprising instinctive caution. On leaving her charge, she is careful to cover the whole with dry leaves, so artfully disposed as to render it difficult, even for one who has watched leer movements, to find the uest; and on returning to it she varies her rout, scarcely ever returning to it twice by the sane course. Hence it is mostly by accident that the nest of the hen is discovered. It not unfrequently happens that several hens associate together and form a common nest, probably for mutual aid and assistance, and rear their broods together. Audubon says that he once found three hens sitting on forty-two eggs. In such eases one of the females at least is ever on guard, no raven or crow then daring to invade the nest. While in the act of incubation, the hen is not readily driven from her nest by the appearance of danger. A person walking carelessly along as if taking no particular notice, may pass a nest within five or six paces, the female crouching low to avoid observation; but, as $\mathrm{Mr}$. Audubon has ascertained, if a person make his approach in a stealthy searching manner, she will quit it while he is yet thirty yards distant, and assuning a stately gait, will move away, uttering every now and then a clucking note, probably hoping by this means to draw off the intruder and baftle his search. The same writer says that the hen seldom or never abandons ber nest if it has been discovered by man, but that if a sllake or any other animal has sucked any of the eggs, she leaves it altogether. Under such circumstances, or when the eggs have been removed, she secks the male, and recommences the preparation of another nest; but, as a rule, she lays only a single batch of eggs during the season. When the eggs are on the eve of hatching, the female will not leave her nest under any cireumstances while life remains; she will even allow an inclosure to be made around her, and thus be, as it were, imprisoned, rather than seck her own safety by flight.

Before leaving the nest with her young brood, the female shakes herself, adjusts her plumage, and appears roused to the exigencies of the occasion; she glances upward and around her, in the apprehension of enemies, and as she noves cautiously along, keeps her brood elose about her; her first excursion is generally to a little distance only from the nest, to which she returns with her brood at night. Subsequently they wander to a greater distance, the hen leading her charge over dry undulating grounds, as if aware of the danger of damp and humid spots. Wet, indeed, is fatal to young turkeys while covered only with down; hence, in very rainy seasons the brood becomes greatly thinned, for the young, if once completely wetted, seldom recover; their vital energies sink under the abstraction of caloric during evaruiation.

At the age of a fortnight, the young birds begin to use their wings; hitherto they have rested on the ground, but now they begin to roost on the low braneh of some large tree, crowding close to each side of the mother, and sheltered beneath her broad wings. They now wander about more frecly, visiting the glades and open lands bordering the woods, in search of wild strawberries and other fruits, grasshoppers, the larvæ of ants and other inseets; and roll themsclves in the sand and 
dust, in order to elear their glowing feathers of louse scales and parasitic vermin : deserted ants' nests are favorite dusting-plaees.

By the month of August, the young birds acquire eonsiderable growth, and use their wings and legs with great vigor and readiness, so that they are able to eseape the sudden attack of foxes, lynxes, and other beasts of prey, by rising quiekly from the ground and mounting the tallest branehes of trees. The young cocks now begin to show their distinetive characteristies, and even to utter an imperfeet gobble, while the young hens pur and leap. Scveral broods flock together, and so eontinue united, till after the Oetober migration, and tlurough the winter, when the males leave the females.

Turkeys, though extremely delicate in thcir infaney, bccome very hardy, and, if permittcd, will roost on the lighest trecs, in the cold dry nights of winter, without suffering injury. The hen, which lays many eggs early in spring, sits thirty days, and covers from twelve to fifteen eggs. It is unncccssary for the turkey coek, as is the ease with gallinaceous fowl, to be in eonstant intercourse with the hen during her period of laying. Two visits from him in that scasoln are sufficient to inpregnate all the eggs. She is a very stcady sitter, and nust be removed to her food and supplied with water, for she would never leave her nest. She wants the alertness and courage and sagacity of the common hen, and might be ealled a fool with mueh more propriety than the goose, which is an intelligent bird. 'The turkey hen is incapable of teaching her young ones how to piek up their food, on which account a poultrymaid should always attend them nntil they are reared.

The author of "Tabella Cibaria" proves it upon the bird that it is "so stupid or timorous that if yon balanee a bit of straw on his head, or draw a line of chalk on the ground from his beak, he fancies himself loaded, or so bound that he will remain in the same position till liunger forces him to move. We male the experiment." We never did; but we doubt it not, though we cammot aecept it as a proof of stupidity. How much wit unay be necessary to balanee a straw unay be doubtful; but gallant ehanticlecr has never been eliarged cither with fear or folly, and yet you have only to take him from his perch, place lin on the table by eandle-light, lold his bcak down to the table, and draw a line with chalk from it, so as to catch his cye, and there the bird will remain spell-bound, till a bystander, rubbing out the linc, or diverting his attention from it, breaks the charm. Many a fowl have we fascinated in our boyish days.*

The fuinen-Fowl. - The Guinea-fowl is slightly larger than the ordinary barn-door fowl, but is inferiol in size to the larger forcign breeds, as the Malay and Spanish; in botlı aspect and eharacter it appears to occupy a position between the pheasant and the turkey. Although long familiarized, the Guinea-fowl has never been fully domesticated, still retaining unuch of the restlessuess and slyyuess of its primitive feral hallits. It is very eouragcous, and will not only frequently attack the turkey, but even prove rictorious in the eneounter.

The cock and hen are so nearly alike, that it is not easy to distin- 


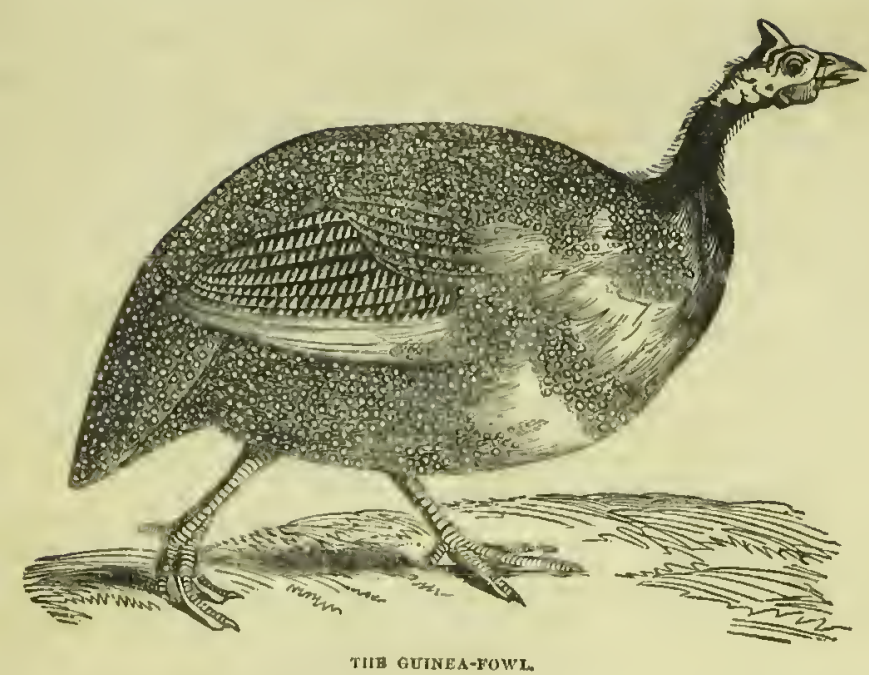

guish then; there is sometimes a difference of hue in ecrtain parts; but this difference only ocenrs oeeasionally, and indeed it is on gait, voice, and demeanor that we must chiefly depend. It must he remarked that they pair; therefore a second ben will be neglected and uscless except for eggs.

Like all the gallinaceous birds the Guinea-fowl is estecmed for its flesh and its eggs, which, though smaller than those of the common fowl, are very exeellent and numerous, the hen commeneing to lay in the month of May, and eontinuing during the entire summer. After the pheasant season, young birds of the year are, on the table, by no means unworthy substitutes for that highly-prized game. Such birds are aceptable in the London market, and feteh a fair priee. The Guineafowl is of a wild, shy, rambling disposition; and, domesticated as it is, it pertinaciously retains its original labits, and is impatient of restraint. It loves to wander along hedgerows, over meadows, through elover ol corn fields, and amidst copses and shruhberies; lienee these birds require careful watehing, for the hens will lay in seeret places, and will sometimes absent themselves entirely from the farm-yard until they return with a young brood around them. So ingeniously will they eonecal themselves and their nest, so eautiously leave it aud return to it, as to elude the searehing glanee of hoy's well used to hird-nesting; but it may always be found from the watehful presence of the eock while the hen is laying. There is one disadvantage in this, the bird will sit at a late period, and bring forth her brood when the seasou begius to be too cold for the tender chickens. 'The best plan is, to eoutrive that the hens shall lay in a quiet secluded place, and to give about twenty of the carliest eggs to a common hen ready to reecive them, who will perform the duties of ineubation with steadiness. In this way a brood in June may be easily obtained. The young must receive the 
same treatment as those of the turkey, and equal eare; they require a mixture of boiled vegetables, with eurds, farinaecous food, as grits, barleymeal, ete.; they should be indueed to eat as often and as much as they will. In a short time they begin to seareh for inseets and their larve; and with a little addition to such fare as this, and what vegetable matters they piek up, will kecp themselves in good game eondition, without eramming or overfeeding. For a week or two before being killed for the table, they should have a liberal allowanee of grain and meal.

Guinea-fowls inate in pairs; overlooking this eireumstance frequently oceasions disappointment in the broods. The period of ineubation is twenty-six days. Thongh they are not unprofitable birds, as they are eapable of proeuring almost entirely their own hiving, they are rejeeted by many on aceount both of their wandering habits, which give trouble, and their disagreeable voice, resembling the noise of a wheel turning on an ungreased axletree.

TIIE PLA-FOWL.-A peacoek in full feather, parading on a green lawn, or from the extremity of a terraee-wall, displaying the full length of his gorgeous tail, is one of the most beautiful living additions to garden landseape. But of fruit he will prove a devonrer, not to be guarded against, and both he and his mate are not mnfrequently murderous assassins of the young of other fowl.

In domestieation it is a rambling bird, unsuited to confined premises; it requires lawns, shrubberies, and wide pleasure-grounds, to which it is an appropriate ornament, whether it moves alout with its tail expanded, or walks trailing it along down aventes of smooth turf, or amongst the woodland glades. Semi-wild as the peacoek is, it is disposed to beeome familiar, and if eneouraged will visit the windows of the honse, in order to reeeive an aeeustomed dole of bread, and when displaying its plumage seems to be aware of the admiration it inspires.

Grain of various kinds, mast, fruits, inseets and their larva, together with small reptiles, eonstitute its food. It is not until the third year that the male aequires his glorious plumage; the aigrette on the heal in this speeies (but not in the Japan peafowl) is eomposed of miniature plumes similar to those of the train. The tarsi are spurred, and when irritated, the pereoek ean use them with full effeet.

For roostiug, the peaeock affeets still higher branehes than the turkey, and, failing these, the gable end of a house or barn, or some elevated situation; and here, throngh summer and winter will it take its station, defying the rain and the eold. Strange that a bird originally from India sliould be so liarly! It would seem as if Providence liad expressly given to the gallinaeeous hirds that quality of eonstitution whieh fits them for aceompanying man into regions fir remote from their natural habitat. Such is the ease, indeed, with all animals essentially subservient to his welfare; and we eaunot but see in this faet a proof of the wisdom and goodness of that God who eommanded man "to replenish the earth and subdue it."

'Though the peafowl roosts in trees, the female ineubates on the gronnd, making in her natual state a rude, inartifieial nest, in some seeluded spot, under eover of the dense jungle. 'The eggs vary in number from five to ten. This eonecalment, as in tho instunee of the tnr- 
key, is necessary; for, actuated by a strange jealousy, the male will break all the eggs if he discovers then; and this feeling actuates our donestic birds, insomuch that the female, during ineubation, must be plaeed in such security as to prevent the access of the male to the nest. Eggs, grayish white; period of incubation, from twenty-seven to thirty days.

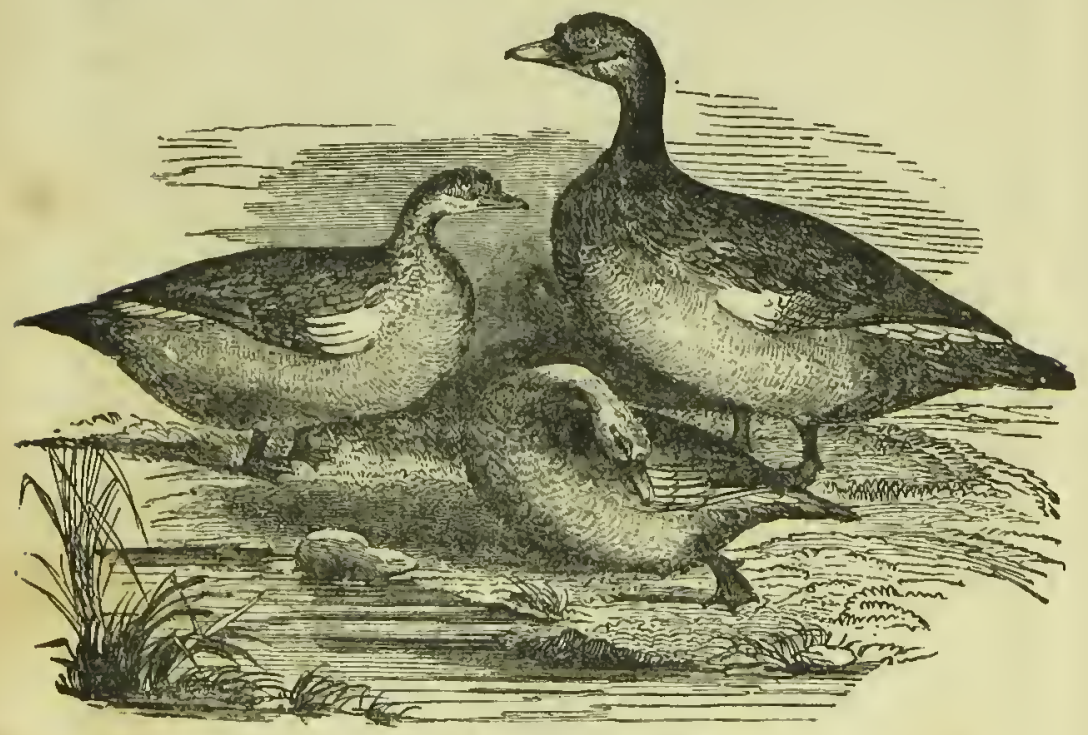

MUBK OR BRAZILIAN DUOKB.

THE DOMESTIC DICK.-Ducks eannot be kept to advantage unless they ean have access to water. This need not be in large quantities. A tub, holding a few gallons, set in the ground, and daily renewed, answering for" a large flock. They are gross feeder's, and exeellent "snappers up of uneonsidererl trifles." Nothing eomes amiss to them : green boiled vegetables, the waste of the kitchen, meal of all sorts made into paste, grains, bread, minnal substances, worms, slugs and snails, insects and their larve, are all aecepted with eagerness. Their appetite is not fastidious; in faet, to parody the line of a song, "they eat all that is luscious, eat all that they ean," and seem determined to reward their owner by keeping themselves in first-rate eondition, if the elance of so doing is afforded them. They never need cramming - give them enough and they will eran themselves; yet they liave their requirements and ways of their own, which must be eonceded. Confinement will not do for thein : a paddock, an oreliard, a green lane, and a pond; a farmyard, with barns and water; a common, smooth and level, with a sheet of water, abounding in the season with tadpoles and the larro of aquatie inseets, - tliese are the localities in whieh the duek delights, and in such they are kept at little expense. They traverse the green sward in 
Indian file (an instinetive habit still retained), and thus return at evening to their dormitory, or emerge from it to the edge of the pond or slieet of water, over which they seatter themselves; thus also they come to the eall of their feeder.

Dueks should always have a lodging-place of their own; they should be separated from fowls, and never housed beneath their'perehes; yet where fowls are kept, a little eontrivance would suffice to inake them a confortable berth in a fowl house. In winter, a thiu beddiug of straw, rushes, or fern-leaves, should be plaeed on the floor of their dormitory, and changed frequently. More than four or five females should not be allowed to a single drake. The duck lays a great many eggs in the season; there are instanees iu which one has laid as many as eightyfive eggs; but these eases are rare; the female will cover with eomfort twelve or fourteen, and in most eases is a steady sitter. When she inelines to sit, give lier a plentiful nest, with some broken straw or hay near at hand, with which to eover the eggs when she leaves them; as nature instruets lier to use this precaution, no doubt it is best to give her the opportunity. Let her be supplied with food and water direetly she leaves her nest; and if she choose to take a bath it will do no harm. It is eommon to put dueks' eggs under hens, and it is ludierons, though somewhat painful, to see the trepidation and anxiety of the foster-mother on the edge of a pond, into whieh the young dueks have plunged, regardless of her feclings and ineessant elucking, a language they do not understand. At what age young wild ducks are taken by their parents into the water we eanuot say; but this is eertain, that if young tame dueks visit the water too early, they are very apt to become eramped and perish. If very young dueklings onee become saturated with water, they invariably perish; they are in this respect as tender as young turkeys. Dueks, although they float on the water, never beeome wet (that is, when properly fledged), for their plumage throws off the fluid, and they return dry from the pond; but dueklings, while yet in the down, get wet, and should therefore liave sparing aeess to water until the feather's supply the place of the early down. Young dueks are easily reared, being fed on meal mixed with potatoes and green meat boiled; they are useful in gardens, which they elear of slugs and snails, without injuring the erops of vegetables. As a eaution, we would here observe, that the ponds to whieh they are allowed aceess should eontain neither pike nor eels; and rats should be extirpated. Rats and weascls often thin flocks of ducklings, to the great loss and vexation of their owner.

The Varicties of the Domestic Duck, are the White Aylesbury, large, plumage perfeetly white, feet yellow, and a Hesh-eolored bill. This is one of the best varieties. The Rouen duck, a large dark-eolored variety, is also highly esteemed. The Irook-billed, remarkable for the peeuliar form of its beak. The Penguin duck, which walks, or waddles in an upright position, like the penguin; the Musk duck, so termed from the strong seent of musk whieh its skin exlialss. This duek is of large size, and its plumage of a glossy blue-black. The Eust Indian, or Buenos Ayres duck, is a small and very beautiful variety, black, with a brilliaut metallic luster on the feathers. 'These, and the various colored eall-ducks, are highly ormamental. 
The egg of the duek is by some people very mueh relished, having a rich piquaney of flavor, which gives it a decided superiority over the egg of the common fowl; aud these qualities render it much in request with the pastry-eook and confectioners-three duek eggs being equal in enlinary value to six hen eggs. The duck does not lay during the day, but generally in the night; exeeptions rcgulated by eireunstances, will, of course, oceasionally oeeur. While laying, the duck requires more attention than the hen, until she is aecustomed to resort to a regular nest for depositing her eggs-onee, however, that this is effected, she will no longer require your attendanec.

THE DOMLSTIC GOOSE.-The best variety of the domestie goose is that which raries least in eolor. Gray is the best color. Mixed colors should be rejected.

As to breeding geese. These birds, as has been aseertained by M. St. Genis, will pair like pigeons; and even if the number of ganders execeds that of the geese, no noise or riot takes place, mutual eloice being evidently the ruling principle. Amongst other experinents tried by M. St. Genis, he left, besides the patriareh of the floek, two of the young ganders, unprovided with mates, but still those couples that had paired kept eonstantly together, and the three single ganders never attempted to approach any of the females during the temporary absenee of their lords. M. St. Genis also remarked, in the course of his observations, that the gander is more frequently white than the goose.

The goose deposits from ten to twenty eggs at one laying; but, if you do not desire her to sit, you may, by removing the eggs as fast as they are laid, and at the same time feeding lier highly, induee her to lay on from forty-five to fifty. This is, however, unusual, and it is unprofitable. When tolerably well eared for, geese may be made to lay, and even hateh, three times in the year. This eare eonsists merely in high feeding and good housing early in the spring, so as to have the first brood early in, Mareh; but we would rather have two good broods reared than three bad ones, and we are, therefore, more disposed to recommend patience and moderation.

The goose will, when left to the unassisted promptings of nature, begin to lay about the latter end of February, or the beginning of Mareh. The eommeneement of the laying may be readily foreseen by marking such geese as run about earrying straws in their mouth. This is for the purpose of forming their nest, and these individuals are about to lay. They should, then, of eourse, be watehed, lest they drop their eggs abroad. Onec a goose is shut up, and compelled to lay her first egg of that laying in any particular nest, you need be at no further tronble about her; for she will continue to lay in that spot, and will not stray on any account elsewhere.

We ean always detect the inelination of the goose to sit or hatch. This is known by the bird kecping in the nest after the laying of each egg longer than isual. The hateling nest should be formed of straw, with a little hay as a lining; and so formed that the goose will not fling the eggs over the side when in the aet of turning them. You need not banish the gander; on the contrary, lct him remain as near the uest as he chooses; he will do no mischief, but will act the part of a most vigi- 


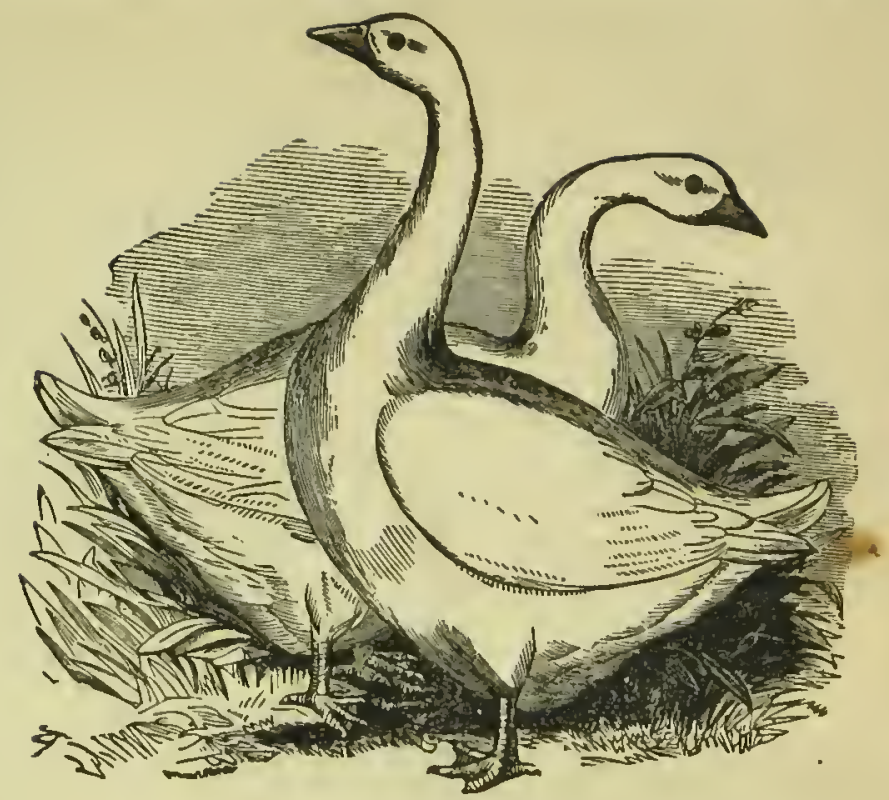

EMIDEN OR BIFMEX GEFSF,

lant guardiau. About fifteen eggs will be fonnd is many as a goodsized goose ean properly eover. Do not meddle with the eggs during the ineubation, and do not meddle with the goose; but, as she is somewhat heavier than the ben, you may leave her food and drink rather nearer to her than is neeessary with eommon poultry, as, if she chaneed to absent herself from the eggs suffieiently long to permit them to eool, she might beeome disheartened, and desert her task altogether. It is, however, unneeessary to put either vinegar or pepper in her food or water, as recommended by some, or, in stort, to meddle with her at all.

The goose will sit on her eggs for nearly two months; but the neeessary period of ineubation beiug but one, the early hatehed goslings must be removed lest the more tardy might be deserted. About the twenty-ninth day the goslings begin to ehip the shell; and if their own powers prove inadequate to tlieir liberation, aid may be rendered them, and that, also, with mueh less risk than in the ease of other young birds, the shell and its membranes being very liard and strong, and the young tlemselves also hardy, and eapable early of enduring hardship. The best plan is to bave the eggs set, of as nearly as possible equal freshness, that they may be hatebed at one time.

On first being hatehed, turn the goslings out into a sunny walk, if the weather will permit of sueh proeedure; but do not try to make them feed for, at least, twelve hours after leaving the shell. Their food may then be bread soaked in milk, porridge, eurds, boiled greens, or even bran, mixed with boiled potatoes, taking eare not to give the food 
in too hot a state, while you equally avoid giving it eold. Avoid rain or eold breezes; and see, therefore, that the walk into which you turn the young goslings be sheltered from both wind and weather. The goslings should also be kept from water for at least a couple of days after hatehing. If suffered too early to have fiee aceess to water, they are very liable to take eramp-a disease which generally produees permanent lameness and deformity, and but too frequently proves fatal.

Geese should have an inelosed court or yard, with houses in which they may be shut when oeeasion requires. It is better, lowever, to eonfine them as little as possible; and, by suffering them to stroll about, and forage for themselves, the expense of rearing them will fall comparatively lightly on you, so that you will not be conseious of any outlay. Geese require water, and eannot be advantageously kept when they eannot have aecess to it; still, however, we lave linown them to thrive where they had no aceess to any pond or river, but had only a small artificial pool, construeted by their owners, in which to bathe themselves. When geese are at all within reach of water, they will, when suffered to roam at liberty, usually go in seareh of, and diseover it, and will, afterward, daily resort thither. Though the birds are thus fond of water, all danip about their sleeping plaees must be serupulously guarded against. Grass is as neessary to the well-being of gcese as water; and the rankest, eoarsest grasses, such as are rejeeted by eattle, constitute the goose's delieacy.

TIIE WILD G00SE.-Canada Goose, or Cravat Goose (Anser Canadensis), Necseash and Mistchayneescah of the Cree Indian, Wild Goose of the Anglo-Amerieans. Hearue, Wilsou, Audubon, Bonaparte, and others have given us full aecounts of the habits and nianners of the Canada goose in a state of nature. It is the eommon wild goose of the United States, and its regular periodieal migrations are the sure signals of returuing spring, or of approaching winter. 'The traets of their vast migratory journeys are not confined to the sea-coast or its vieinity, for, in their aerial voyages to and from the 11orth, these birds pass over the interiol on both sides of the mountains, as far west, at least, as the Osage River. "I have never," says Wilson, "yet visited any quarter of the country where the inhabitants are not faniliarly aequainted with the regular passing and repassing of the wild geese." It is an opinion in the states that they visit the lakes to breed. Most, however, it would appear, wing their way much farther northward, for from the Canadian lakes they migrate to still higher latitudes on the setting in of spring. Hearne saw, them in large flocks within the aretie eirele, pushing their way still northward. Captain Phipps observed them on the coast of Spitzbergen, in latitude $80^{\circ} 27^{\prime} \mathrm{N}$. Audubon found them breeding on the coast of Labrador, and states that the egrs, six or seven in number, of a greenish white, are deposited in a roughly made nest. Bonaparte states that they breed everywhere thronghout the IIudson's Bay territory, and have been observed in the middle of July on the Copper-mine river, not far from its debonehure, aceompanied by their newly-hateled young. The ery of the species is imitated by a nasal repetition of the syllable wook, or, as Wilson writes it, honk.

The destruction of the Canada geese during their migrations is enor- 
mous : the autumnal fight lasts from the middle of August to the middle of Oetober ; those which are taken in this season, when the frosts begin, are preserved in their featliers, and left to be frozen for the fresh provisions of the winter stock. The feathers constitute an article of commeree, and are sent to England. The rernal flight of these geese lasts from tho middle of April until the middle of May. Their arrival in the fur countries from the south is impatiently expected; it is the harbinger of spring, and the month is named by the Indians the goose-moon. Dr. Richardson, in his Fauna Boreali-Americana, describes as follows the interest caused by the appearanee of the flocks:- "The arrival of this well-known bird is anxiously looked for and hailed with great joy by the natives of the woody and swampy districts, who depend principally on it for subsistence during the summer. It makes its first appearance in flocks of twenty or thirty, which are readily decoyed withing gunshot by the hunters, who eoneeal themselves and imitate its call. Two, three or more are so frequently killed at a shot, that the usual price of a goose is the single charge of ammunition. One gonse, which when fat weighs about nine pounds, is the daily ration of one of the Company's servants during the season, and is reckoned equivalent to two snow-geese (Anas hyperborea.), or three ducks, or eight pounds of buffalo and moosemeat, or two pounds of pemmican, or a pint of maize and four ounces of suet.

"About three wecks after their first appearanec, the Canada geese disperse in pairs throughout the country, between the fiftictl and sixtyseventl parallels, to breed, retiring at the same time from the shores of Hudson's Bay. They are seldom or never seen on the coasts of the arctic sea. In July, after the young birds are hatehed, the parents moult, and vast numbers are killed in the rivers and lakes, when (from the loss of their quill feathers) they are unable to fly. When chased by a canoc, and obliged to dive frequently, they soon become fatigued, and make for the shore with the intention of hiding themselves; but as they are not fleet, they fall an easy prey to their pursuers. In the autumn they again assemble in flocks on the shores of Hudson's Bay for three wecks or a month previous to their departure southward."

The Canada goose feeds on aquatic vegetables and their roots, and delicate marine plants of the genus ulva. To this cliet they add grain and berries in their season.

The flight of this species is laborious and heavy, and generally in single file, or in the form of two sides of a triangle, the leader, some old gander, being the apical bird. From time to time this leader utters his deep "honk," which is responded to by the rest of the flock, and which may be translated, "What elicer, ho?" "All's well!" Very often, however, all is not well, for the line is scattered by the fire of the gunner; often, too, they meet with dense fogs, in whicls they become bewildered, and after wheeling about alight on the ground, where the gunners give them a warm reception. In somo districts the sportsmen take with them into the marshes one or two of the domesticated race, which by their call attract the flocks passing overhead, and allure them to destruction.

Wilson says that, execpt in caln weather, the flocks of Canada geese 
rarely sleep on the water, generally preferring to roost all night in the marshes. When the shallow bays are frozen, they seck the mouths of inlets near the sca, oecasionally visiting the air-holes in the ice; but thesc bays are scldom so completely frozen as to prevent them feeding on the bars at the entrance.

The Canada goose is a bcautiful species, and its flesh is excellent. The head, two-thirds of the neck, the grcater quills, the rump, and tail are perfectly black; the back and wings brown, cdged with wood-brown; the basc of the neck anteriorly, and the under plumagc generally, browuish gray; a few white feathers are scattered about the eye, and a white eravat of a kidney shape forms a conspicuous mark on the throat; upper and under tail coverts purc white; bill and feet black. Such is a brief sketch of the Canada goose in a state of naturc. Man, however, has appreciated its value, and it is kept domesticated not only in America, but in many parts of Europe wherc it breeds frcely. In Amcrica the ordinary gray goose of Europe is very comınon; but this bird does not thrive there so well as in Europe; hence many prefer the Canada goose, which is as familiar, and its cqual in other points.

This species will breed with the common goose; and it is assertcd that the hybrid progeny is far superior in the flavor and sapidity of its flesh to the unmixed progeny of the eommon goose. Buffon, in whose time the Canada goose was kept in a domestic state in France, says: "Within thesc few ycars many hundreds have inhabited the great canal at Versailles, where they breed familiarly with the swans." That is, we suppose, interbrecd with the swans, an instanee of which has not come under our own notice; the intermediate position, however, of this speeics renders the fact probable.

Like the duck and the eommon goose, the Canada goose under domestication ceases to be as strictly monogamous as it is in its wild stato -a eircumstance whieh, in our tame anatida, may result from the plan of kecping but few males, and these in association with a flock of females, so that the ordinary results of pairing - that is, rctiring from the rest to a secluded spot, which the mated pair exclusivcly occupy-arc interfered with. Yet, as may be seen in the instance of the eommon goose, the male generally attaches himself to a particular female, while she is followed by licr brood of goslings over the common, and is energetic in their defense. 'The instinct is not quite obliterated-there is a rcigning sultana.

It is a question worth attention, whether the Canada goose might not with advantagc be more extensively kept in our eountry than it is at present; it is common as an ornament to sheets of water in parks, gardens, and pleasure grounds, but is too mucli neglected as a bird of utility; it is alike valuable for flesh and feathers; it is not so decided a grazer as is the common goose; the precincts of marshes and ponds which abound in aquatic vegetation, for the procuring of which its strong bill and long swan-like neck afford it facility, offer the most advantageous sitcs for its establishment, and in such localities we strongly recommend its adoption. With regard to its management little is to be said; the sitting females require secluded nests, free from intrusion; and the flock, in addition to the vegetables they pick up, require an allowanee of grain. 
Like most birds known both in a wild and domestic state, the latter exceed the former in weight and magnitude.

FEEDING POULTRY,-lt is a bad practice to under feed poultry. From the very first they should liave good and solid food. Steamed potatoes and other roots mixed with meal of the various grains, form a cheap and excellent food. It is not necessary to soak, grind, or boil the grains for fowls, howcver, where they can have free aceess to pebbles to supply their own grinding-mills, by which they tmrn their own grain into flonr. But when pent up and unable to proeure what they so mueh need, meal, and boiled and erushed food should then be given them. The poultryhouse, however, should be constantly suppliel with finc gravel, lime, and pulverized eharcoal-artieles indispensable to the health and improvement of fowls. Green food should be given then daily. Cabbages hung where the fowls can pick at them are a good article. In winter, chopped potatoes, turnips, cte, are the only convenient grcen food. When praeticable, fiesh animal food should be frequently given fowls that are shut ul, or at seasons when they eannot proeure inseets or worms. A bulloek's liver, thrown in the yard, is a cheap and good food for them. Indian eorn is an excellent food, and may be freely given.

Cayenne pepper, indeed all deseriptions of pepper, especially the eayenne in pods, will be fonnd a favorite with fowl, and will be grecdily devoured by them; it aets as a powerfnl stimulant, and remarkably promotes laying; and, when mixed in a ground state with boiled meal, will be found produetive of the best effeets. In this, however, as in every thing else, let moderation be your ruling prineiple.

A different system should be adopted in treating poultry for the table, and for the laying and breeding department.

With regard to feeding fowls for the table, muelı depends on eircumstanees. Spring chickcns may be put up for fecding as soon as the hen ceases to regard them, and before they lose their first good eondition. In their fattening-pens they will luave no opportunity of pieking up little pebbles; their mills, therefore, will be inoperative, and the diet must eonseqnently be pultaceous, viz., bread and inilk, barley-meal, or oatmeal and milk, and meal of steamed potatocs mixed with barleymeal. Some reeommend the occasional addition of a few grains of eayenne pepper, or of dried nettle-seeds, which the foreign feeders are in the habit of giving. Where ehickens have the run of a good farmyard, and plenty of food, it is a work of supererogation to pen them for fattening; they will be ready at any time for the table, and their flesh, being in its healthy state, will be sweet and juiey, delieately tender, and sufficiently fat. Some, indeed, prefer fatted fowls; bnt this is a matter of taste; to many the greasy fat of poultry is very disgusting.

The praetice of cramming poultry by the hand is quitc common, though not to be rceommended. In Franee they have maehines by which one man can cram fifty birds in half an hour. It is somewhat on the principle of a foreing-pump. The throats of the birds are held open by the operator until they are gorged through a pipe, which eonveys the food from a reservoir bclow placed on a stool. In fiftcen days, fowls are said to attain the highest state of fatness and flavor by this feeding. In addition to the ordinary paste of barley-meal, or meal mado 
into little balls with milk, the dried seeds and leaves of nettles have been reeommended by the continental poulterers, some of whom give a little henhane-seed to induce sleep, while others put out the eyes of the prisoners as the most effectual way of keeping them in a state of darkness, which is considered essential to their becoming rapidly fat; and under the pretext of relieving then from the irritation of vermin, they pluck the feather's from their heads, bellies, and wings. While fowls are thus preparing for the knife, though their bodies are elosely confined, their hinder parts are free for evacuation and eleanliness, and their heads are at liberty to take in fresh supplies of nutrinent.

Poultry are the hetter for high feeding from the very shell, and on this account the heaviest eorn is often far eheaper for them in the end than tailings, as regards the flesh, or the size and substantial goodncss of the egrgs. Young ehickens may be put up for feeding as soon as the hen has ceased to regard them, and before they lose their first good condition. When chickeus are wanted for domestie purposes, they are often left at liberty in the farm-yard, and if they have plenty of good food, they will be in the inost healthful state for the table, and rich and juicy in flavor.

POULTRY-IIOUSES AND YARDS,-Those who intend to rear fowls or any kind of poultry on a large seale, should have a distinet yard, perfeetly sheltered, and with a warm aspeet, well feneed, seeure from thieves and vermin, and suffieiently inelined to be always dry, and supplied with sand or ashes for the cocks and hens to roll in, an operation necessary to disengage their feathers from vermin: running water should he especially provided; for the want of water, of which all poultry are fond, produecs constipation of the bowels and inflanmatory diseases; and for geese and ducks, bathing is an indispensable luxury. $\Lambda$ contiguous field is also nceessary, for frce exercise, as well as for the supply of grubs and grass to the geese. The fowl-house should be dry, well-roofed, and fronting the east or south, and, if practicable, at the baek of a stove or stahles; warmth being eondueive to health and layiug, though extreme heat has the contrary effeet. It should he furnished with two sinall lattice windows, that ean be opened or shut at pleasure, at opposite ends, for ventilation, which is frequently necessary; and the perehes should be so arranged, that ono row of roosting fowls should not be direetly above another.

M. Parmentier has shown* by what arrangement a house twenty feet long and twelve feet wide may be made to aecominodate one loundred and fifty hens at roost. The plan is simply this : the first roosting-perel (rounded a little at the upper angles only, for gallinaceous fowls eannot keep a firm hold on perfeetly eylindrieal supporters) should be placed lengthways and rest on trestles in each end wall, six feet from the front wall, and at a convenient height, which must depend on the elevation of the house from the floor, which should be formed of some well cousolidated material that ean he easily swept. Another perch should be fixed laddcr-ways (en échelon) above this, but ten inehes nearer to the baek wall, and so on, until there are four of these perehes, like the steps 
of a ladder when properly inclined, butwith a suffierent distance between the wall and the upper one to allow the poultry-maid to stand conveniently upon when she has oceasion to examine the nests, which it is her duty to do every day at least onee, and iu the forenoon. The highest of these she ean reach by standing on a stool or step-ladder. By this contrivance the hens, when desirous of reaching the nests, have no oceasion to fly, but merely to pass from one stick to another. If the size and form of the house permit, a similar eonstruetion may be made on the opposite side, eare being taken to leave all open space in the middle of the room, and a sufficiently wide passage for the attendant to pass along the walls. It is not at all required to have as many nests as hens, beeause they have not all occasion to oceupy them at the same time; and besides, they are so far from having a repugnance to lay in a common reeptaele, that the sight of an egg stimulates them to lay. It is however true, that the most seeluded and darkest nests are those which the hens prefer.

The nests, if built into the wall, are in tiers from the bottom to the top, the lowest being about three feet from the ground, and a foot square. If the laying-chambers consist of wooden boxes, they are usually furnished with a ledge, which is very convenient for the hens when rising.

But the best receptacles for the eggs are those of basket-work, as they are cool in summer, and ean easily be removed and washed. They ought to be fastened not direetly to the wall, as is generally the case, but to boards fixed in it by hooks, well elinehed, and with a little roof to eover the rows of baskets. They will thus be isolated, to the great satisfaction of the hen, which delights in the absenee of all disturbing influenees when laying. All the ranges of nests should be placed chequewise, in order that the inmates, when coming out, may not startle those immediately under: those designed for hatehing should he near the ground (where instinet teaches the hen to choose her seat), and so arranged that the hens ean easily enter them without disturbing the eggs.

Wheaten or rye straw is the most approved material for the bedding, being cooler than hay: the hens are sometimes so tortured by lice as to forsake their nests altogether, in an agony of restlessness. A Dorking housewife lias assured us that she once lost an entire eluteh, from having, as she believes, given a bed of hay-seeds to her sitting hen. The ehicks were all glued to the shells, and thus destroyed, owing, as she thinks, to the high temperature oceasioned by the fermenting seeds.

For all purposes two coeks in a good run are considered in the poultry counties eontiguous to London as sufficient for twelve or fourteen hens, but in France they allow twenty mistresses to each eock, which no donbt is on aecount of the ligh temperature there. In a eonfined yard, five hens are suflicient for one cock in our cold eountry, and a double set will not answer in very limited space. When there are two or more cocks, care should be taken not to have them of equal age or size, for in this ease they are always jealous and quarrelsome; if oue is decidedly aseendant, the other will never presume to dispute with him. It will be judicious also to avoid the introduction or ehauging of cocks in the breeding scason, for the hens require constant intereourse with them, and several days frequently elapse before they beeome familiarized with 
a stranger. The best way is to bring in the new cock in the summer, either as a chick, or late in the year in the moulting season, when he will not take too much notiee of the hens. As a general rule it would be well to have one a yearling and the other a year older. In the third year, the cock, who then becomes lazy and excessively jealous, should be killed.

In selecting eggs for hatehing, care should be taken that they are not at the utmost more than a month old, but their condition for hatehing will greatly depend upon the temperature of the weather: vitality eontinues longest when the weather is eool.

It has been asserted that the future sex of the bird is indicated by the shape of the egg; the round produeing the female, and the oblong the male. But this is eontradicted, and, we believe, with suffieient reason, and it is impossible not only to foretell the sex, but even to ascertain whether the egg be fceundated. This however is certain, that if the air-bag (at the obtuse end), whieh has been mistaken for the germ, and the purpose of whieh is to oxygenate the blood of the eliek, be perforated even in the least eonceivable degree, the generating power is lost altogether. Those eggs only which have been feeundated by the male are possessed of the vital prineiple. The number of eggs for a hen should not exeeed sixteen, as she cannot impart the necessary warnth to more. It is by no means uncommon with experienced breeders to place two hens on the same day on their respective eggs, and then on the twenty-first day when the broods are out, to give the maternal charge of both to one of the hens, removing tbe other to another set of eggs, which, if she be a steady setter, she will hatel as in the first instance. This, however, must be deemed a cruelty, though some hens would instinetively continue to sit until death. They would, however, become so attenuated by continued sitting, as to lose the power of cominunieating to the eggs the neeessary degree of warmth. The practiee of the Surry breeders is to feed tho hen on oats while sitting, as less stimulating than barley, which tbey give to the laying hens on account of this very quality.

CAPOXIZIVG.-The making of eapons, that is, emasculating the males, is practieed a little in some of the Englisls counties, and very mueh in France, where the females are also rendered ineapable of breeding, and termed in their unsexed eondition poulardes, in order to give them the tendency to fatten. An incision is made near the parts, and through this the finger is introdueed to take hold of and bring away the genitals, but so earefully as not to injure the intestines: the wound is then stitehed up and rubbed with oil or grease; and the eomb (which appears to be an unneessary and gratuitous pain and insult to the sufferer) is often cut off. The females are treated much in the same way, when they do not promise well for laying, or when they have eeased to be fertile; they are deprived of the ovarium. The subsequent treatment is similar to that in the former case. Care is taken to give them good food for three or four days, and during that time to keep them in a place of moderate temperature, to aroid the danger of gangrene, whieh, considering the time of the year-midsummer, when the operation is usually performed -is a very probable consequence. Pullets of tbe largest breed are 
seleeted for the purpose, as they yield the greatest weight to the poultercr; and if employed in hatehing, eover the greatest number of eggs.

DISEASES OF FOWLS.Fowls and poultry in general are subjeet to various diseases; as, apoplexy, diarrhac, rheumutism, the pip or thrush, the croup (often termed roup), the gapes, inflammation of the tail gland (also ealled the roup, though the term is improperly applied), and other diseases which are not understood. Great diffieulties attend the treatment of poultry diseases. Who attends to them? what eomplaint do they makc? and when they die, how fow pcrsons aequainted with the symptoms before death make post-mortem examinations, and then refer thosc symptoms to the morbid appearanees whieh his sealpcl reveals? The following are the ehief aetive disorders among them; apoplexy, evideneed by inflammation of the membranes of the brain, or by effusion of blood within or upon it; peritoneal inflammation, rapidly fatal; inflammation of the lungs, including the bronchial tubes; tracheal inflammation (or gapes) with parasitie worms in the windpipc; inflammation of the mucous membrane of the intestines, evideneed by previous dysentery; and inflammation or intumeseenee of the rump gland, symptomatie of a febrile condition. But what ean be said as to the treatment of poultry under discase? Very little. To speak the truth, neither are their diseascs well understood, nor is the treatinent of them generally sueeessful. A few observations on partieular eomplaints may, however, be useful.

Apoplexy makes its attaek in most instanecs without the slightcst previous warning. Could it be known that a bird was in danger of an attack, means might perhaps be taken to insurc safcty. Aviary birds, in the finest health apparently, will drop dead from their pereh from this eausc. They are often over-fed; they have not to exereise themselves in the task of seeking for food; they have an allowanee in unlimited measure, but have no aeeording mcasure of museular excrtion; they "do not earn their bread before they eat it," as wild birds do. "Experientia doeet." The best advice to give, as to the means of prevention, is to fced birds a little in proportion to the exercise whieh they have the power to take.

The Pip, or Thrush, may be regarded as a token of derangement of the mucous membranc of the alimentary eanal generally, and not as a loeal discase; it is symptomatic. Its cure will be effeeted by low diet; that is (in the ease of fowls), by an allowance of fresh vegetable food, mixed with potatoes and a little oatmeal, granting at the same time a plentiful supply of pure water. Give of eastor oil a teaspoonful, or thereabouts, according to age and strength. Do not serape the tongue, nor use rougl modes of eleaning it, but apply a littlc borax, dissolved in tineture of myrrh and water, by means of a eamel-hair peneil, two or three times a day. The symptons of pip eonsist in a thiekening of the mombrane lining the tonguc and palate, whieh eauses an obstruetion of the free inspiration, and makes the poor sufferer gasp for breatl ; the plitmage beeomes ruffled, the bird mopes and pines, the appetitc fails, and is at last utterly extinguished, the bird at length dying, worn out by fever and starvation.

Gapes (Inflammation of the Trachea) is a very fatal disease, to whieh all $12^{*}$ 
our domestic gallinaceous birds, as well as pheasants and partridges, are subject, and whieh often occasions great mortality. In thc first instance it appears to arise from a croupy or catarrhal affeetion, which is indieated by running at the nostrils, watcry eyes, altcration of voice, and loss of appetite and spirits. The bird dies. If the trachea be examined, it will be found replete with narrow worms, about half an ineh in length, imbedded in slimy mucus. This singular worm is the Syngamus trachealis, or Distoma lineare. It consists of a long and a short body united together; the long body is the femalc, the short body the male; cach, were it not that they arc permancntly united together, being an animal distinct and perfeet in itself. Whether these parasitic worms are the cause or consequence of the disease, we pretend not to say, nor can we tcll how they become introduced into the trachea; this, however, seems to bc ccrtain, that their removal is requisite to give the feathered patient a chanee of rceovery. This can be donc by mcans of a feather, ncatly trimmed, which is to be introduced into the windpipe, and turned round onee or twice, and then drawn out. It will dislodge the worms, and briug back many of them adhering with slime unto it. This plan requires great dexterity, and some knowledge of the anatomy of the parts; a slow, unskillful operator may kill the already lialf-suffocated bird, instead of curing it. Another mode of destroying these worms is, by putting the birds in a box, and making them inhale the fumes of tobacco, thrown into it through the stalk of a tobaeco-pipe. Some rccommend the forcing of tobacco-sinoke down the bird's throat, and others that the month be crammed with snuff; while many place faith in the efficacy of a pinch of salt, introdnced into the back part of the inouth. Something like a scicntifie mode of treatinent may, however, bc suggested. Give a grain of calomel, made up with bread into a pill, or two or three grains of Plummer's pill (pil.hydr. submur co., London Pharmaeopœia); after which let flour of sulphur bc administered, with a little ginger, in pultaceous food eomposed of barlcy-meal. In the mcan time let the bird bc kept in a dry warm slicd or room, apart from the rest of the fowls, as the disease may bc infections. Let the mouth and beak bc washed with a weak solution of chloride of lime. A correspondent, who dates his letter from Wootton, Christehurch, spenks of turpentine as the only remedy on which to depend. His words arc: "Half a teaspoonful of spirits of turpentine, mixed with a handful of grain, is a ccrtain cure in a few days, giving a handful of sucl grain to a couple of dozen young ehicks cach day. It is the most perfect and unfailing remedy. I eominunicated this receipt to the 'Gardeners' Chronicle' (No. xxix., July 17, 1847, p. 476), and I understand it lias been found by other persons besides myself to be successful - perfeetly so. In this part of England it is the only disease of ehickens; and for two seasons the number that died of it was very grcat." The rationale of this mode of treatment is as follows:- the turpentine is absorbed into the systcm, and so bronght into contact with the parasitie worms in the windpipe, to whieh it is speedily fatal; they are then ejeetcd with the mucus; and the cause of irritation bcing thus removed, the bird specdily recovers. Wct, ill-fecding, an ill-ventilated forlhouse, confinement on a spot or plot of ground tenanted year after year 
by fowls, without attention to eleanliness, to renovation of the soil, and a proper allowanee of gravel, ashes, fresh vegetables, ete.; these are the eauses whieh produee this and many other diseases. The gapes is an epidemie disease, whieh often thins the preserves of pheasants and the eoveys of partridges.

Inflammation of the Lnngs, ineluding the bronehial tubes, is not uneomman. Its symptoins are quiek breathing, often with a rattle or râle very andible, dullness, disorder of plumage, vaeaney in the eye, and indisposition to stir. In this, death ean hardly be prevented. IIuman patients ean explain their feelings-eattle, to a eertain degree, indieate them, and speak in dnmb eloquenee; but birds give little indieation, by voiee or manner, leading to what the medieal man ealls diagnosis. The persevering use of eod-lirer oil will give relief, and even effeet a temporary, or at any rate an apparent eure; but who would like to breed from the bird.

Peritoneal Inflammation, or Peritonitis.-This disease runs so rapid a eourse, that death not unfrequently oeeurs before any marked symptoins have appeared indieative of aetive disease. The bird perhaps appears a little drooping - it refuses to eat; but as it is highly fed, this eireumstanee oeeasions no surprise; it retires to its roost, and is found dead in the morning. Examination at onee reveals the eause of death-the peritoneal membrane exhibits all the indieations of aetive inflammation. We have notieed the oeeurrenee of the same disease among e univorous mammalia. An animal appears to be as well as usual-at least it attraets no observation-but it dies suddenly. On opening the body, the eanse is inanifest-Perilonitis has done its work.

Inflammation of the Mneous Membrane of the Intestimal Canal is usually evineed by dysentery. The bird pines; it is purged; in a little time the evaenations beeome nore or less tinged with blood, and death ensues. Damp and improper food are the eauses of this affeetion. It ean be treated with sueeess only in the early stage. First give a small quantity of eastor-oil. This will elear the bowels of irritating seeretion. Afterward let the bird have doses of the Hydrargyrum cum crela (of the London Pharmaeopœia), rhubarb, and laudanum :- of the hydrargyrum eum eretâ, three grains ; rhubarb, two or three grains; laudanum, two, three, or four drops. Mix in a teaspoonful of gruel or gum-water. To be given every alternate day for a fortnight.

Simple Diarriuea may be generally cured by a ehange of diet, and a little ehalk given in gruel.

Constipation of the Bowels will yield to eastor-oil, and a diet upon oatmeal porridge and green vegetables.

Asthmia.-Both fowls and pigeons are affeeted with this eomplaint, whieh is evideneed by diffienlty of breathing and a wheezing, rattling noise on inspiration. It is the result of a thiekening of the bronehial tubes from previous inflammation, often aeeompanied by an alteration in the strueture of the eellular tissue of a portion of the lungs. There appears to be no rational plau of treatment likely to effeet a eure.

Intlanmation and Intumeseenee of the Rump Glind is generally symptomatie of a febrile eondition of the system. To this affeetion the term roup (an indefinite term for all the diseases of poultry) is often applied, 
The treatment is simple. Let the swelling be opened by a laneet, and the matter gently squeezed out; afterward foment well with warm water; put the bird upon a diet of oatmeal and green vegetables, and, if neessary, give a teaspoonful of eastor-oil. Be sure that the roostingplace is elean and well ventilated.

Mloulting. - This proeess is natural, and eonsists in the gradual exehange of old. feathers for new ones. Nevertheless it often happens that birds in a state of domestieation have not suffieient vital energy for the aceomplishment of the ehange. They require improved diet, warmth, and good water. Of course their roosting-place must be properly sheltered and ventilated. A grain or two of eayenne pepper, made into a pill with bread, may be given daily with advantage. Saftron is useless; but a nail, or any bit of iron may be put into the drinking-trough, in order to render the water chalybeate.

Fowls are subject to a loss of feathers, whieh must not be confounded witlı moulting. At first the plumage appears ruffled and disarranged; then the featliers begin to drop out, and continue to fall till the bird is greatly denuded. In the mean time it is dull and destitute of appetite, and beeomes thin and feeble. This disease is inost eommon among poultry kept in a limited space, debarred from exereise and fresh air, with a wet soil beneath them, having little or no gravel, nor any dusting-plaee in which to elean their plumage : it is analogous to the inange in eattle, and is not easily cured. A ehange of diet, good air, cleanliuess, and a dusting-place (or, as some eall it, a dust-bath), are essential. Some recommend small quantities of sulphur and nitre mixed with butter to be daily given.

As the suecessful treatment of diseases may sometimes depend on promptitude, it may be useful for every poultry-keeper to lave a convenient supply of a few simple medicines. The following may be named as rather suggestive than complete:-1. jalap, in fifteen-grain powders; 2. hydr. cum cretâ, in three and five-grain doses; 3. cod-liver oil; 4. eocoa-nut oil ; 5 . flour of brimstone; 6 . Baily's roup pills.

In eases where inflammation is suspected, the hydr. enm eretâ is pronounced by the best judges to be a valuable medicine. To a grown fowl five grains, with from five to fifteen grains of jalap (aceording to the strengtl of the dose required), may be given. Jalap is a very good poultry medieine. Coeoa-nut oil and flour of brimstone make perhaps the best ointment for white eomb, and one whieh is less disfiguring to the plumage than turmerie. Baily's roup pills are almost universally known and appreciated.

SIIIPPIVG POULTRT AND EGGS.-Messrs. Charles R. Iuntington \& Co., produee eommissiou merehants iu New York, give the following directions as to slaughtering and shipping poultry and eggs:-

Food in the erop injures the appearance, is liable to sour, and purehasers object to this worse than useless weight: therefore keep from food twenty-four hours before killing. Opening the veins in the neek is the best mode of killing. If the head be taken off at first, the skin will recede from the neek-bone, presenting a repulsive appearanee. Most of the poultry sent to this market is "sealded" "or wet-pieked," but "dry-picked" is preferred by a few, and sells, to a limited exteut only, 
at good prices. Poultry may be pieked dry witlout difficulty, if done immediately after killing. For sealding ponltry, the water should be as near the boiling point as possible, without actually boiling; the bird, held by the legs, should be immersed and lifted up and down in the water, three timcs-the motion helps the hot water to penetratc the plumage, and take proper effect upon the skin. Continue to hold the bird by the legs with one liand, while plueking the featliers with the other without a monent's delay after taking out-if skillfully handled in this way, the feathers and pin-feathers may all be removed without breaking the skin. A torn or broken skin greatly iujures the appearance, and the priee will be low in proportion. The intestines or the erop should not be "dlawn." After removing the feathers, the head may be taken off and the skin drawn over the neck-bone aud tied; it shonld next be "plumped" by being dipped into water, nearly or quite boiling hot, and then at onee into cold water abont the same length of time. Some think the hot plunge suffieient without the cold. it sliould be entirely eold but not frozen before being packed. If it ruaches market without freezing it will sell all the better. In paeking, when practieable, use clean hand-threshed rye-straw ; it this camnot be had, wheat or ont straw will answer, but be sure that it is elcan and free from dust of any kind. Plaee a layer of straw at the bottom, then alternate layers of poultry aid straw, taking care to stow suugly, back upward, legs under the body, filling vacancies with straw, and filling the packages so that the cover will daw down very suugly upon the contents, so as to prevent shifting or slucking on the way. Boxes are the best packages, and should eontain from one hundred and fifty to three hundred. Lange boxes are inconvenient, and more apt to get injured. Nimber the packages, mark the contents, the gross weight, and the tare of each on the eover" mark plaiuly to our address, placiug your own initials also on the paekage, and send invoice and railroad receipt by mail, to aroid errors or delay in reporting sales.

Eggs require spccial care in packing. First-seeure strong and substantial barrels, either good sceond-hand barrels, or new split-stave oak ones. Commence by putting a sulald quantity of clean wheat or oat straw at the bottom of the barrel; cover this with dry, sound oats, as clean, bright, and as free from dust as you ean get them, say about two inclies of uniform depth. Then pack eggs on the side, leaving a space of threc-quarters of an ineh between the outside tier and the staves; fill up the layers by making regular ticrs. Carefully avoid packing so close togrether as to erowd them. Use plenty of oats, and slake the barrel well after covering each layer with oats. Leave a spaec of about three inches at the top, and cover the top layer of eggs with about two inches' deptls of oats. Cut, of brown paper, a cirele slieet that will just fit the barrel, and lay it on the oats. Then put on this a sufficient quantity of wheat or oat straw, or dry hay, to require a strong pressure to get the head into the crozen. Examine egrgs closely, and be particular in counting. Always mark the quantity of eggs in dozens, and the number of bushels of onts contained in cael harrel upon the head, ancl also upon the side of each barred, with the initials of your name or firm. Eggs paeked in this manner will command ready sale in this city, at the 
current market price, withont any deduction for broken or rotten eggrs, at all times. In order to avoid elaims for rotten eggs it is desirable to ship fircquently.

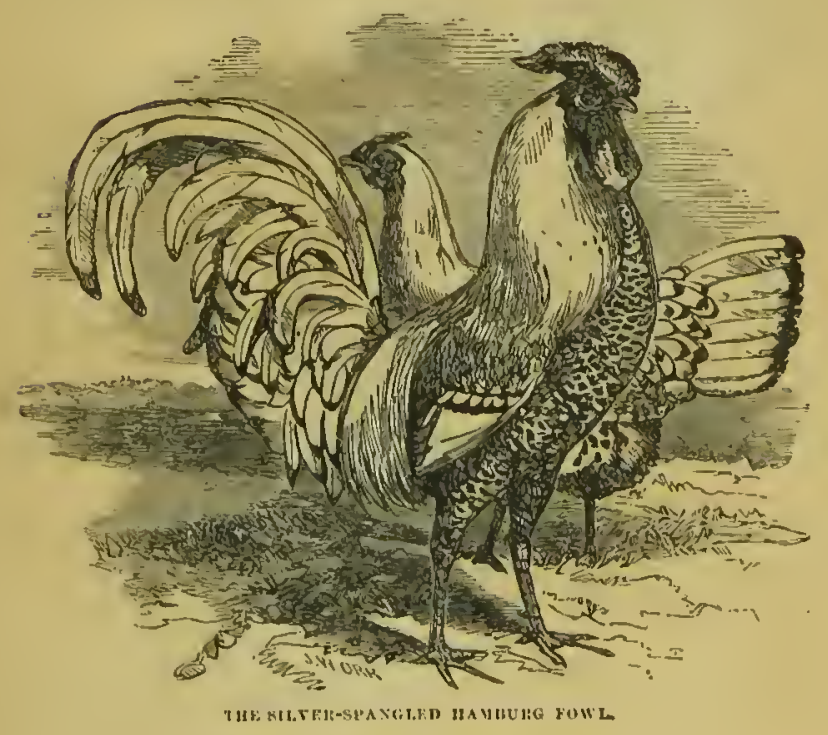




\section{$\mathrm{B} \mathrm{E} \mathrm{E} \mathrm{S:}$}

THEIR

HABITS AND MANAGEMENT. 


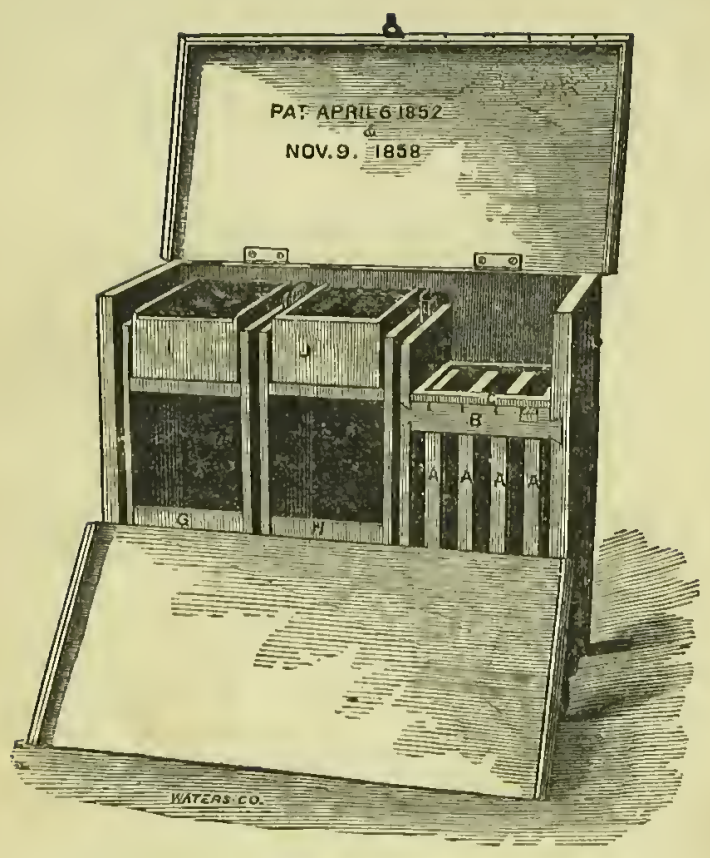




\section{BEES.}

\section{THEIR HABITS AND MANAGEMENT.}

THREE CLASSES OF BEES,-The queen Bee is the sovereign, and literally the prolifie parent of all her subjects. She is the sole monareh.

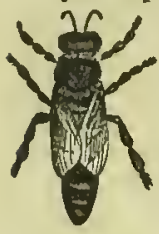
Her body is longer, larger, and more pointed than that of the others, and her wings are much shorter than theirs, hardly reaching beyond her middle, whereas those of the others cover the entire body; Ler belly and legs are of a deep golden eolor, and the latter are not furnished with the little brushes whieh those of the workers have, to help them in eollecting the floury matter which they require for making honey.

Aneedote of two Queen Bees, - The queen bears no rival authority. If there should be a second queen, she is either sent forth with an attendant swarm of colonists, or put to death by the other bees.

Huber gives an account of a duel between two queens, who, issuing from their nurserics in the same hive, rushed into deadly confliet, eatching eaeh other with the teeth. As if they drcaded the fatal eonsequences to themselves, which would follow from unsheathing their darts, they had the prudence to separate at the height of their fury and fly away. But the other becs compelled them to decide the point of sovereignty on the spot, and then foreed them to the contest again. This was done repeatedly, after intervals of breathing-time, until the stronger of the two, seizing the other by the wing, stabbed her to deatl.

The queen-bee commenees depositing her eggs when about five days old; during the heat of the season she lays from one hundred and fitty to two hundred eggs per day, and lays with little or no intermission from early spring to the middle of autumn.

Drones.-The seeond class of bees are the drones. They are bulkier

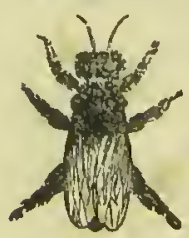
in the body than either the queen or the working-bee. Their head is rounder, proboscis shorter, eyes fuller, an additional artieulation to the antenne, and no sting. They also make more noise in flying than the other bees. The drones arc the males of the hive; by them the royal mother is imprcgnated and Ler eggs fertilized. How or when this intereourse takes place lias long furnished philosophers with a subjeet for controversy and inquiry; and it has not even yet been set at rest in such a manner as to admit being proved to a positive demonstration.

The drones form about a tenth part of the population of a hive. They are eertainly idle and lazy, as are the husbands of other queens; yet they fulfill the objeets of their creation. They cannot collect honey, for they have not the nccessary organs for the purpose; their teeth are too little and too short for breaking off the capsules, their mouths are not well formed for sucking the swects of flowers; and their lcgs have not those brushes or powder-puffs which enable the other to bring home 
the farina wanted for making wax. During the summer they find food for themselves, and pass their time in lounging from flower to flower, and they are not found in the hive during the winter. By an extraordinary instinet, they are massaered without pity by the females before this period, in order to save the winter stoek of honey, until they have departed voluntarily to some nook where they may rest until wanted in the next spring. These poor things have no weapons of defense.

Working Bee.-The third elass is the working bee. The working bee is eonsiderably less than either the queen bee or the drone. It is

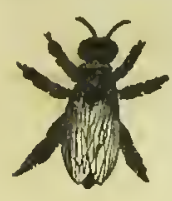
about half an ineh in length, of a blaekish brown eolor, eovered with elosely set hairs all over the body, whieh aid it in earrying the furina it gathers from the flowers; and on the tibia, or forearm, as it were, of the hind leg, is a eavity of eup-like form, for the reeeption of the kneaded little ball of pollen. It is the working bee whieh eolleets honey and pollen, and whieh forms the eells, eleans out the hive, proteets the queen, looks after the eondition of the young brood, destroys or expels the drones, when these are no longer neeessary to the well-being of the eommunity; who, in short, performs all the offiees eonneeted with the hive and its eontents, save only those whieh have referenee to the reproduetion of the speeies. The working bees are of no sex, and are furnished with a horny and hollow sting, through whieh poison is ejeeted into the wound it niakes; this poison is of an aerid eharaeter, and of great power in its effeets, proving fatal to any inseet, and instanees are on reeord of its proving so to horses and eattle, nay, even to human beings: when human beings, however, are stung (an aeeident that will happen very seldom, if they use the preeautions in manipulating with their bees, that shall be detailed in the eourse of this volume), they ean instantaneously obtain relief by pressing upon the point stung with the tube of a key; this will extraet the sting and relieve the pain, and the applieation of eommon spirits of hartshorn will instantaneously remove it; the poison being of an aeid nature, and being thus at onee neutralized by the applieation of this penetrating and volatile alkali.

WONDERFUL INSTINCTS AND CONTRIVANCES OF BEES.-The eontrivanees of bees in the eonstruetion of their eombs are anongst the most wonderful works of God, as regards inseet ereation. "The form of the eomb is in every eountry the same, the proportions aeeurately alike, the size the same, to the fraetion of a line-go where you will, and the form is proved to be that which the nost refined analysis has enabled mathematieians to diseover, as of all others the best adapted for the purpose of saving room, work, and materials. This diseovery was only made about a eentury ago; nay, the instrument that enabled us to find it out was unknown for half a eentury before that applieation of its powers. And yet the bee has been for thousands of years, in all eountries, unerringly working aeeording to a fixed rule, which no one had diseovered until the eighteentl eentury."

We may instanee among other surprising illustrations of the ingenuity of these wonderful ereatures, that they lay the foundations of their cities at the top of the hive, and build downward. They have straight 
passages, or lanes, across their different dwelling-places, wide enough for two bees to pass.

ADPANTAGES OF KEEPING BEES.-It is strange, that though the expense of establishing stoeks of bees, where there is a garden, is so trivial, and the possible gain so great, few people take the trouble of keeping them. Country eottagers too generally negleet to take advantage even of an adjoining eommon or lonely garden, which speeially invite to beekeeping. Where eottage gardens are very small and erowded, and multitudes of ehildren swarm, it is certainly difficult, if not dangerous, to introduee tens of thousands of bees, with their formidable stings; but in numberless instanees where bee-husbandry is negleeted, it might be pursued with some profit.

No farmer, nor even humble eottager, who has a pateh of garden, and lives near eommons, heath-eovered hills, or woods, should be without lives, as the great supply of bees' food is obtained by their own exertions. It is not the rarest and most beantiful flowers which afford the best honey, but those which abound in the open fields as well as in the garden; the flowers of inountain heath, elover, trefoil, beans, vetches, wild thyme, turnips and eabbages, privet, elder, bramble, rue, and, above all, the blossoms of the eommon furze, are among the best materials for honey. The eost of food is seareely any thing, and the return may be considered elear gain.

The trouble of rearing bees, compared with the pleasure or the profit, is nothing.

MANAGEMENT OF BEES.-To him who is about engaging in bee-keeping, the first question of interest is, how to seleet his stoek. As a rule, the spring is the best season to purehase a stock of bees, as they have then passed the easualties of the winter ; and the question of profit, so far as the first year is concerned, is quite elear, if the swarns are judieiously ehosen. Their value depends upon the health and number of bees, and the time they have oeeupied the hive. The number in a eolony ean be judged of with comparative aeeuraey by raising the hives and examining them, or by the hum produeed on giving them slight taps; and by the weight, as shown either by lifting or weighing. The age of a swarm is told by the eolor of the eomb; in new swarms the eolor being white, and varying from that to nearly black, in very old swarms. The brood eombs grow thieker with age, and the cells and the bees hatehed in them are therefore smaller, and the latter feebler. It is poor eeonomy to purehase a eolony more than two years old.

Transportillg Bees,-Let the hive be plaeed on a eloth, the ends of which must be earefully tied over the top; if it is to be taken to a distanee, the hive so tied up may be swung on a pole fastened aeross a eart from side to side; this prevents the jolting to which it might otherwise be subject, which would disturb the bees, and probably shake down the eomb. When arrived at its destination, let the hive be placed on the stand, and if any of the bees have fallen out on the eloth, place them near the entrance, and they will soon find their way in.

SPRING MANAGEIIENT. - As soon as the weather is fine exanine your hives by lifting them earefully from the stand. Clear away all the dead bees and refuse matters which have colleeted during the winter. Rub 
the monldiness and damp from the floor-board, and let it be well dried. The bottoms of the eombs often beeome mouldy in the winter, especially in light stoeks, and it will be a good thing to eut off the lower portions, whieh may be done with a table-knife, and without danger, by turning the hive on one side, in the evening or early in the morning, or at any time, if you take the preeaution of wearing a bee-dress, hereafter deseribed. The bees will soon renew the eombs, and their health will be improved by the removal of the deeayed portions.

Feeding.-Many swarms die in spring for want of food, and the wise apiarian will therefore feed his bees liberally, bearing in mind that what be gives them is not lost, as they ean fully store for their owners' use what is not needed for their own support.

Begin to feed the light stoeks; a liberal supply of food will be amply repaid by the eonsequent health and vigor of your bees, and the abundant store they will eolleet for your future benefit. And do not prematurely eneourage the bees to go in seareh of food, but rather eonfine them to their homes. Guard against the admission of stranger bees while yours are feeding. Give honey now, if you ean, rather than syrup, as it forms a better ingredient than sugar in the jelly which supports the young brood.

The eonsumption of food in a hive is now perhaps greater than at any period of the year. The queen lays from one hundred to two hundred eggs daily, and the inerease of the brood is so prodigious, that it is impossible for any exeept a well-stored hire to meet the demand for food. Many persons wonder that their bees die in the spring, when they have survived the winter; but the food eonsumed during the cold weather is eomparatively very small to what it is during breeding time. On this ground, then, feed abundantly all the stoeks, but especially the light ones.

Feeding outside the hive, by plaeing food at the entranee, is a bad method, as stranger bees are attraeted, which deprive your bees of a proportion of that which you have provided for them. Feeding at the bottom disturbs the bees, lowers the temperature of the hive when the food is introdueed, and thus oeeasions loss of life; therefore, to obviate these evils, ingenious feeding-pans have been invented for supplying food at the top of the hive.

The following direetions for feeding bees are from "The Bee-Keepers'

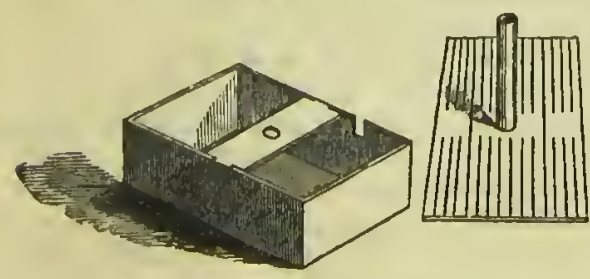

PEELPS' BEE-FLEDER.

Chart:" "Before feeding is eommeneed the hives should be set down upon the floors and the entrances for the bees so elosed as to adimit only one or two at a time. Two or three ineh auger holes may be bored in the top, and the feeder plaeed by the side of them and eovered with a small box, and this eovered with an old earpet to prevent other bees from seenting the feed." Phelps's Bee-Fieeder is thus figured 
and deseribed, and it may lead the ingenious to adopt it on a better plan:

"It consists of a tin pan, or tray, placed in a wooden box, with a float to fit, and a tin tube passes through the float and is secured to it on the under side. The float may be raised at any time, even if it is covered with bees, by means of the tube, and the syrup poured into the pan through the tube by inserting a funnel in the top of it. The float supports the bees and prevents them from getting into the syrup, and as they consume the syrup it settles down with them. A picee of wood aeross the top of the box, with a hole for the tube, keeps it in its place, and a pane of glass on eaeh side of this confines the bees, and affords an opportunity to observe their operations while feeding."

The same author recommends the following eompositions for feeding bees :

First: two pounds West India or Orleans sugar; three gills ale; one gill Malaga wine; (if the ale and wine eannot be had, use sap or water,) one teaspoonful fine salt. Mix together in a tin or copper vessel; set it over a slow fire; stir oeeasionally until it arrives to a boiling point; set it off, and let it cool, remove the seum, and it is fit for use.

Seeond: one gallon (or twelve ponnds) of West India or any other honey; four pounds West India or Orleans sugar; one gallon maple sap or water; half a pint ale; two tablespoonsfuls fine salt. Heat and mix as above. This composition may be made without the ale by using water.

It is however doubted by some experieneed bee-keepers, whether the general feeding of bees is, upon the whole profitable. It is argued that while it is wise to feed bees that have not suffieient food to keep them alive, any thing given them beyond that is unprofitable, and produees an inferior artiele of honey, if any thing but pure honey be fed. The following is Mr. Eddy's argument:

"The theory of feeding bees on a large seale has had its day. It has presented splendid results for a time, and resulted at length in splendid failures. Cheap honey, or a eomposition, has been used, and the bees have been fed freely, under the impression that whatever they stored in their eells must of course be honey of the first quality. I would ask why Cuba or Southern honey is not made of the first quality when it is stored up for the first time in Cuba or Florida, if bees have the power of eonverting an inferior artiele into one of superior quality. The true reason is, that much of this so-ealled honey is taken from the sugar plantations, or from tlowers which do not furnish the best honey. And the seeond transportation, although done by "Yankec" bees, does not produee any ehemieal ehange in the artiele which is fed. Honey is gathered, not made by the bees. Those who purehase in market Cuba honey which is packed up in "Yankee" boxes, do not get the best end of the bargain. They have yet to learn that the packing or transportation does not make it the fine-flavored and wholesome article which is found in white elover upon all our hills in New England. The feeding of the bees on a large seale, or with a view to secure larger quantities of surplus honey, operates unfavorably upon the bees in a variety of ways, and the prineipal objections to it are the following; 1. There 
is no profit in it. No man gets the quantity of honey whieh he feeds. 2. It prevents the bees from going abroad to gather honey from the fields. 3. If the bees are fed liberally late in the fall and early in the spring, there will be very few empty eells in which to rcar young bees. 4. It is deceptive, because a cheap and inferior artiele is sold for one of superior quality. 5. It results, in the process of time, in the extinction of the bees. The feeding of the bees may be practiced with advantage whenever they are not amply supplied with winter stores, a thing which happens to late swarms and to thosc from which large quantities of honey have been taken. For this purpose a ehcap artiele may be used to help them through the winter. It may be desirable to take from the bees all the white clover honey which can be obtained in boxes with a view to supply the bees with a cheaper article."

Daily Examination of the hives for the removal of all filth tends to domesticatc the bees, and if done gently the effect is to so aceustom them to their keeper that he ean handle them with perfect impunity.

The Position of the Bee-Ilouse should be frec from exposure to the north and west winds, and from the morning sun. A southwest exposure is recommended by the best authorities.

SUMMER MANAGEMENT.-Preparations for Swarms.-Every thing neeessary shonld now be prepared for the establishment of swarms, which may be expected during the next two months, else there may be running hither and thither, while the swarm takes wing and is lost through your delayed preparation. Hives, or boxes if you intend to make use of these, must be kept dry and sweet; stands or stools to place them on must be prepared, and a hand-brush, leather gloves, crape, or other covering for the face, placed in readiness.

As bees require water to drink, especially through this and the next month, it is necessary to place some for them, if there is no pond or rivulet near. Cotton says that, in the Isle of Wight, the people have a notion that every bee goes down to the sea to drink once a day. Water is needful for them in the breeding season, and they will drink water witl salt in it, and like it better than the freshest brook that runs. It is very curious to see how they will flock by thousands to the drinking-troughs in April, May, and part of Junc; and then their thirst seems to be quenched all of a sudden, for not one will be seen at them. The reason seems to be that they do not want so much water after the greater part of the young brood is hatehed.

Shallow dishes or plates filled with water, and having thin boards, piereed with small holes, Hoating on it, from which the bees may drink without fear of drowning, are convenient. Sinall pebbles o1 moss, placed in the plates with the water, will answer almost as well.

'The hives, if old, should be scalded to destroy the larvæ of insects. If new, the only preparation is to wet the inside with salt and water, sweetened with either honey, molasses, or sugar.

Indieations of Swarming.-The most certain indieations of swarming are, the hive appearing full of bees-clusters of them gathering on the outside, and sometimes hanging from the alighting-board; they also neglect their daily toil and refrain from going abroad in search of sweets, even though the weather be ever so inviting. Just before they take 
flight, the hive is hushed, the bces are silent and carefully loading themsclves with provender for their journcy. For two or three nights prior to swarming, you will also hear a peculiar humming noisc within the hive; the second swarm is announced by a different sort of buzzing, being, aecording to some writers, the result of a contest as to whieh of the two queens shall lead off from the hive. It is the old queen who lcads off the first swarm.

If a swarm be about to quit the hive, the slightest change of wcather will prevent their doing so, but nothing so effectually as a shower of rain; henec an excellent mode of preventing it, when the becs eluster on the outside of the hive, by syringing them with water from a common metallie syringe. When a swarm leaves the hive, if it do not settle on some trec or bush, but remains in the air, and you fear its going off to too great a distance, if not evading you altogether, you may bring it down by throwing up sand or dust, which the bees mistake for rain, or by firing a gun, which they mistake for thunder; hence the old fashion of the country people following a swarm with the noise of firc-shovels and frying-pans. You must be the more diligent in at once seeuring your swarm, for it is a faet that the bees send out scouts previous to swarming, whose duty it is to select a proper habitation for the colony. It is, on this aceount, a good plän, when you antieipatc a swarm, to leave an empty hive, previously smeared on the interior with honey, in some convenient place, but not too near the old one.

When the swarm scttles, the bees collect themselves in a heap round the queen, hanging to each other by means of their feet. When thus suspended from a tree, they may be sccured by sinmly holding an empty hive under them, and tapping the braneh from which they are suspended. They should, in this case, be sprinkled with honey and water, and eonfined for about twelve hours. When a swarm divides into two or more bands, and settle scparately, it is probable that there are two queens. In this ease you mist secure one of them.

If, througl your inattention, a sccond swarm éomes off, you should, as soon as you have hircd it, sceure its queen, and return the swarm to the hive; indeed, when deprived of its queen, it will usually immediately return of its own accord. Swarming is a subject, we have rcason to believe, which is very generally misunderstood, most persons desiriug to promote it, conceiving that the greater the number of swarms the richer will the hives be in August. The very reverse of this is the case; for, when a hive is weak in numbers, a sufficient number of bees cannot be spared to go forth for honey; and hence they will bc scarcely able to collect enough for their actual support, far less to collect any surplus for their mastcr's bencfit. Hear Mr. Jiriggs:

"The swarming of bees is a subject on which much misconecption prevails. Most persons who kecp their bees in the old straw-live plan, and suffocating system, appear to anticipate their swarming with nuch anxiety, and to be of opinion that the greater number of swarms-firsts, sceonds, thirds, etc.- they obtain from their old hives during the summer, the more remunerative will they prove to the owner at the end of the season; whereas the reverse of the above practice is much nearer of being the best system to follow, which I shall endeavor to elueidate. It 
has been proved from observation, that the average percentage of swarms have been twenty-four in May, sixty in June, fourteen in July, and two in August; from which it will appear that June is the principal month for swarming, in ordinary seasons; and it is in June and July that the greatest quantities of honey are stored up by the bees, when managed in a judicious manner.

"When the swarming is assisted and encouraged during June and July, the old stocks are considerably wcakened, and the swarms are employed in building combs in their new hives, collecting pollen, and attending to the young brood, until the best part of the honey-storing season is over; so that, at the honcy harvest in autumn, it will frequently require the contents of five or six old stocks, or late swarms, to produce as mucl pure honcy as might have bcen obtained from one eolony on the system of managcment which is recommended."

In collatcral boxes, and in capped hives, swarming may be prevented by affording the bees additional accommodation, and reducing the tcmperature; and, for this cnd, it is recommended, by most apiarians, that the hive or box should be furnished with a thermometer as well as ventilator. We think, however, that even those who do not possess these acconmodations may manage well cnough by proper observation and attention to the symptoms we have detailed. When these appear in a collateral box-hive, open one of the partitions, and admit the bces into a new apartment; if all be full, take off a box, empty and restore it. In the case of a capped hive, remove the bung, and admit the bees to the cap; if full, remove, empty, and restore it. On this subject Mr. Briggs says :

"The most favorable degrecs of heat for the prosperity of the brood are from $75^{\circ}$ to $90^{\circ}$ in the stock live, and from $65^{\circ}$ to $75^{\circ}$ in the side boxes. The heat in a prosperous hive is sometimes upward of $70^{\circ}$ at Christmas, and will, in hot summer weather, sometimes rise to near $120^{\circ}$, at which time the combs are in great danger of being damaged, and of falling to the floor of the hive; this may, however, be prevented, by giving extra room when required, and by shading the hives from extreme heat, as previously directed. It should always be borne in mind that all operations with becs should be performed as carefully and as speedily as circuinstances will permit. The late Mr. T. Nutt remarked, in a conversation with him a few months previous to his decease, 'that in removing boxes, glasses, slides, etc., the apiarian should proceed in a manner so steady and cautious; that the bees should scarcely know that their habitation had bcen meddled with ;' in which remarks I fully eoneur."

After having a new swarm, you must also recolleet, that if unfavorable weather follow their departure, you must feed them, otherwise they will be starved; indeed, it would be well if each new swarm were always fed for a few days, as this will assist them in gaining strength in numbers and in store, before the principal part of the honey season goes over. In conclusion we would merely say, that the weight of a good swarm should be from five to seven pounds, and that all under five pound in weight should be united to others, as being too weak in numbers to support themselves. 
Bee Dress.-In hiving a swarm it is as well to be proteeted with a proper bee dress. Prevention is better than cure, and it is better to be sure than sorry; yet bees are eertainly less apt to sting at this time than any other.

Some persons are particularly unhappy in possessing those qualities whieh render them disagreeable to bees. The main objeetions are, exeessive timidity, and likewise, with some, an unpleasant odor, in some instanees the result of personal negligenee, but frequently of peculiarity of eonstitntion. The remedies are a bec-dress for the sormer, and the use of some strong perfume whiel the bees like, and whieh will effectually eoneeal whatever is offensive to them.

"I have gone among then," says Mr. Worlidge, "in their greatest anger and madness, only with a liandful of sweet herbs in my hand, fanuing about my faee, as it were to obseure and defend it. Also, if a bee do by aecident buzz about you, being unprovided, thrust your face amongst a parcel of boughs or herbs, and he will desert you. But the most seeure way of all, and beyond the completest harness yet published, is to liave a net knit with so small meshes that a bee cannot pass through, and of fine thread or silk, large enough to go over your hat, and to lie down to the eollar of your dress, through whieh you inay perfeetly see what you do without danger, having also on a pair of woolen gloves."

Mr. E. W. Phelps deseribes the following forn of a bee-dress, whieh may be procured at an expense not exceeding twenty-five eents: "Take one and a half yards of thin, light, three-quarter muslin, and a pieee of wire-cloth (sueh as is used for mcal sieves) about six inehes square; it may be obtained of wire-weavers in most of our large towns and eities, or of hardware dealers. Lay the muslin over the head, with the ends down over the slioulders, with one end of the selvedge in fiont and the other baek. The baek part may be eut and fitted to the head, and a eord run in to gather it around the neck, and the wire-eloth sewed in over the faee, first rounding the corners in shape of the faee. It should extend down below the inouth, to afford free respiration, and the muslin sewed togetlier below the wire-eloth, suffieient to extend below the vest. It may be worn under a coat, but it is not tlie best way, as it is usually warm weather when it is woru, and with the liead-dress and a coat over it, a person will be very uneomfortable on aecount of the heat; besides, the bees will erawl up under one's coat and vest, and when in close quarters will oftell priek through the shirt, and tiekle a person under the ribs. To prevent this and the other difficulty, I have prepared myself with a garment made of the same kind of unaterial as the head-dress, and in the form of a hunting-shirt, open before, with buttons close togetlier, to button up tight. I first put on my head-dress, and then over this my hunting-shirt, buttoned under nly pants; and with a pair of thick woolen gloves, with stoeking legs sewed to the wrists, to draw up over iny sleeves, and my pants tied over my boots, I ean defy all the forees they ehoose to bring against me.

Clustering Shrubs and Bushes, plaeed in the vieinity of the apiary, are recommended by experieneed bee-keepers, as tending to diminish the diffienlties of hiving bees. Mr. Pholps direets to "take the seed-ends of 
xaullen-stalks about a dozen in number, and tie these to the tops of poles; the poles should be set in the ground so as to be easily taken up after the bees have settled on them; by managing in this manner, the hive may be set in the apiary, before hiving, and the bees may be earried on the pole and laid by the side of the hive, when they will enter it; this saves the trouble of moving the hive after hiving, and eonsequently no bees will be lost. The mullen tops should be attaehed to the poles so as to lie nearly horizontally. What there is in the mullenstalks so attraeting to the bees I know not, unless it is their rongh, uneven surfaee, whieh affords the bees seeurity against falling; old dry weather-beaten stalks are as good as any."

Mr. Weeks direets that "when there are no fruit-trees nor shrubbery in the immediate vieinity of the bees, it is found that they will eluster on bushes artifieially set down about the hives; say, take hemloek, eedair, or sugar-maple bushes, six, eight, or teu feet high; sharpen the largest end, with the foliage remaining on the top, and set them down like bean-poles promiseuonsly round about the hives; two, three, or four rods distant; when the bees swarm, they will usually eluster in a body on some one of them, which may be pulled up, and the bees shaken off for the hive. Some apiarians eonfine a buneh of the seed-ends of dry mullen-stalks near the top of the bush, so as to represent, at a little distanee, a eluster of bees: this is said to be unfailing in eatehing swarms. Others reeommend to drive down two stakes, two or three feet apart, and eonfine a stiek of suffieient strength to eaeh stake two or three feet from the ground, forming a eross-bar, so that, when a board twelve feet long is laid, one end resting on the eross-bar and the other on the ground, the bees will eluster under it, admitting it is at a reasonable distanee, and yet so far from the old stoek as to be out of hearing of their hum. Any one will know how to turn the board over, and set an empty hive over the bees.

"The hiver is made of three rough boards, half an ineh thiek, seven inehes wide, twenty-four inehes long, nailed together like a common trough, open at both ends, - a strap of iron riveted on its ontside, aeross the eenter of eaeh board, with a shank or soeket to insert a rod to handle it with, so that when inverted by means of the rod, and plaeed over the bees when alighting, it forms a kind of lialf bive, whieh they readily enter. 'There should be from a dozen to twenty half-ineh holes bored through the top board, so as to let the alighting bees enter through the holes. Whlien a small proportion of the bees are found in the hiver, it may be noved a few feet from the limb, whieh may be shaken with another rod witl a hook on its end, whieh disengages the bees, and in a few moments the whole swarm will be found in the hiver. By the addition of ferules and joints, the hiver may be raised to any reasonable height. Thus the labor of elimbing, the use of ladders, and eutting the limbs of preeious fruit-trees, is entirely dispensed with. It likewise enables the apiarian, in large establishments, to divide out and keep separate his swarms, whieh might otherwise alight many in one body."

Nlanagement of Black Combs. - The eombs in hives that have stood for several year's beeome blaek and useless, beeause the bees never clear out the eells in whieh the brood has been reared, and the skins whieh the 
young bees east gradually fill up the eells until they are too small for breeding in ; in consequenee the hives get weaker and weaker; swarming eannot take plaee, and at last the bees die.

To prevent this fatal end, you may in spring, before breeding-time eommenees, after fumigating the bees a little, turn up the hive and eut out half the eomb; put the bees in again, and during the summer they will fill up the vaeaney, and have room for breeding. Next spring take out the remainder of the old eomb in the same way. One stoek treated in this manner is said to have been kept for the long period of sixty years. Sometines, when a stoek has not swarmed, it is desirable to remove the bees altogether from the old hive into a new one. This must only be done during the first week in July; if attempted earlier, the new brood not being all hatehed, many bee-grubs would be dcstroyed, and you would have a weak stoek. On the other hand, if transferred later, there would not be time for then to make their eomb and lay up winter store. Fumigate or intoxieate the bees at night, and put them while stupefied into a new hive, taking eare that the queen is among them; plaee the hive on the stand in the same position the old one oeeupied, and on the morrow they will eommenee their labor as a new swarm. If the weather be fine, they will do well; but if they are found to be weak in autumn, take them up and unite them with another stoek.

September is the proper time for earefully inspeeting your stoeks, to aseertain whieh will stand the winter, for feeding those whieh have not suffieient food, and for uniting weak stoeks to strong ones, as previously reeonmended.

By gently striking the hives, you may judge whether they eontain many or few bees, from the greater or lesser noise they make in the buzzing whieh inmediately follows. Do not leave any to remain for the winter but sueh as weigh about twenty pounds.* But reeollect that a hive with two thonsand bees will be more likely to survive than one with ouly one thousand, even if the latter have mueh more honey. On this aecount it is important to aseertain the number of bees, and to make your standing stoeks as strong as possible, to maintain suffieient heat in the hives.

FALL FEEDING, - Whatever food is required innst be given now, as bees should not on any aeeount be fed in winter. Those who have not the eonvenience of the feeding-pans for the top of the hive, should provide little hollow troughs made of elder, or a split bamboo stopped at the ends. These must be filled with honey or syrup, and then pushed into the mouth of the hive at sunset, the entrance being earefully elosed, to prevent otlier bees from entering. Feeding should not take plaee in the daytime, as the hive will then be subjeet to the depredations of wasps and robber-bees whieh are attraeted by the seent, and not unfrequently devour the whole of the honey. In the morning, a little before sunrise, remove the troughs. Continue this operation nightly until you are sure

* Age will cause hives to weigh heavicr than their legitimate contents would call for; this is oceasioned by an accumulation of bee-bread and tho east sloughs which had formerly served as envelopes to the young. In tho case of old hives, you must, therefore, allew from two to five pounds, accerding to age, for these inatters. 
your bees have sufficient winter provision. Do not be stingy : as we have said before, you will reap the profit of liberality to your bees in the rich return they will make.

IIOUSING, etc., IN WINTER. - When there is snow upon the ground, the entrances of your hives should be entirely closed, and a screen or shade should be placed before the hive, in case of an accidental sunny day occurring, in order to prevent the bees from encountering even a single deceptive ray.

Another danger from which you are imperatively called upon to protect your bees during winter is dampness. It is to this cause that the loss of many a stoek is to be attributed-an internal dampness, generated within the hive itself. This is best remedied by careful ventilation, placing a bell-glass, well covered with flaunel, over the aperture on the top of your hive or box, removing it from time to time, and earefully wiping away from its interior the damp formed by condensed vapor; this remedy is at once simple and effieaeious.

It will, perhaps, appear to some of our readers a singular experiment, resorted to by some bee-keepers, viz., burying the hives. When this is to be attempted, the hive should be buried in a cool, dry, shady place, among leaves, about a foot deep, and the interment should be performed during the first or second week of November.

A friend buried a hive of bees in the first week of November, about a foot deep, amongst dry leaves, etc., and disinterred it in the last week of February, when it was just two pounds lighter than it was in November, and the bees in a lively and healthy state. Another person immured a hive of bees in the earth fonr feet deep, in the second week of November, and at the end of January it was removed, and weighed only three ounces less than it did before it was buried.

The above experiments are worthy of attention; a shed having a northern aspeet, and which is as dry as possible, would be a suitable place for further trials. The principal points by which there might be cause for fear of failure, would, as in other cases, be from dampness, disease for want of fresh air, and attacks from vermin, cte. To prevent the former I would recominend that the hives be plaeed on a long frame of wood, covered by a web of closely worked wirc, and raised a few inches from the ground, the ends of which should communicate with and be occasionally opened to the fresh air. A long tube should also be placed from the hole at the top of each hive to the open air of the shed, from the upper end of which any dampness might be condensed by bellglasses, and conveyed away as already directed.

Among other obvious mistakes, I may mention the reeommendation to give the bees an opportunity of leaving the hive, and going abroad every finc day, already detailed. What advantage is expeeted to be derived from thus permitting the insects to go forth? They may be supposed to want exercise. This is a mistake; for the bees naturally erowd together, and remain in a sort of torpor during winter, and every thing that could tend to interfere with, or aronse them from it, must, of course, prove eontrary to their natural instincts, and eousequently, prejudicial. During winter the bees are inactive.

HIVES AND BOXES,-By having proper hives and boxes for bees, the 
following advantages are obtained:-First-the power of depriving bees of honey at pleasure, without injuring them. Secondly-obtaining it in larger quantities, and of finer quality. Thirdly-The means of a more thorough ventilation, the keeping of the bees cool, and of enlarging their accommodations at plcasure, and the power to control swarming at will.

ENEMIES OF BEES.-These are far more numerous than their diseases, and arc as follows:

Poultry, mice, toads, frogs, snails, slugs, eaterpillars, moths, millipedes, wood-lice, ants, licc, spiders, wasps, hornets .

Fowls should not be permitted in any apiary. They will kill and eat the becs, and such as they do not destroy they will annoy and disturb -besides, your bees will probably ocelipy a stand in your garden, a quarter whence other reasons should necessarily exclude poultry.

Mice.-While the bees are vigorons, the field-mouse does not dare attack the hive; but as the cold approaches, and the bees become less active, he enters, and commencing with the lower comb, ascends by degrees as the bees become torpid, until he either elcars all away, or by the smell of the honey he has wasted on the board, induces other becs to come and plinder. As soon as the warm weather returns, the surviving bees will leave the live in disgust. The remedy is easy. By having your straw hives, if you use such, coated on the exterior with Roman cement, you will prevent mice from nestling in the straw, whence otherwise they would speedily eat their way into the interior, and by narrowing the entrance of the live in the manner already described, you will effectually keep out these littlc intruders. If your stands bo placed on a single foot, or if the feet are so placed under the foot-board as to lcave a wide, projecting ledge, no mice can arrive at the hive.

Toads will kill bees oceasionally, but not in suflicient numbers to excite our alarm; but the toad is rather to be regarded as a friend to the bees - one of their enemies, the spider, being his favorite food.

Frogs may be classed with toads.

Sulails and Slugs.--These creatures are not absolutely enemics of bees, as they have no design upon them or their honey in entering the hive, but merely do so from accident. The mischief done by them consists in the alarm and confusion they oceasion. The bees first attack the unfortunate intruder and kill him with their stings, after which they earefully incase him in propolis, effectually preventing putrefaction or the production of maggots.

Caterpillars. - The most dreaded is the eaterpillar of the wax-moth, so called from the ravages it makes amongst the eonıbs as soon as it obtains entrance. By liaving the legs of the stand placed as we liave already described, no caterpillar ean climb up to the hive; but this will not prevent the moth herself from entering and depositing eggs in the hive; and so prolific are these moths, that a single brood would suffice to destroy a whole stock. Periodical fumigation, anid eutting away such combs as contain the grubs, are the remedies to be adopted. Moths are only nocturnal enemies. During the day you liave nothing to fear from their attacks. Let the entranec to tho hive, therefore, be ncarly closed in the evening, and you will protect your bees from their ravages. Columella recommends, as a trap for moths, a bottle, or other vessel, 
with a long and narrow neek inereasing gradually to a wide mouth, and having a light in the neek, to be plaeed under the hive in the evening. We ean roueh for the effieaey of this trap-it will destroy numbers. Another partieular to be attended to is to have your stocks suffieiently strong; and for this purpose, if the live attaeked be weak, unite it to the bees of another hive, in the manner already deseribed. The bees are themselves, if suffieiently strong in numbers, both willing and able to destroy the intruders. If weak, they will neeessarily fall vietims.

Millipedes, or Irood-lice, are often produeed by the stands being made of deeayed wood, or the hive being plaeed too near an old hedge. Let the stand be of new wood, and strew soot on the ground under and about the hive. This will also serve in part as a proteetion against the attacks of ants.

Ants.-You should always destroy sueh ants' nests as you find in the neighborhood of a hive. In the West Indies, glass-feet are used to prevent these insects from getting into furniture, ete. Might not sueh be used with advantage for bee-hives?

lice.-These are small parasitieal insects of a red eolor, whieh adhere to the body of the bee, and derive their nourishment from their juiees. They are about the size of a grain of nustard-seed, or ratler smaller.

Reaumur and others tried many remedies for these troublesome inseets, but in vain, till at length Madame Vieat diseovered that Morocco tobaeeo will kill the liee without injuring the bees.

Spiders, - Brush away their webs wherever you meet with them near your stand.

Irasps and llornets.-These inseets are most noxious to bees. Dig up and destroy their nests wherever you meet with thein; but you will most effeetually get rid of them by offering a reward for every queen wasp brought to you in spring. The destruetion of eaeh queen is tantamount to that of an entire nest; and if this plan were generally adopted, wasps would eventually be extirpated.

Birds- - Among those whieh are the greatest cnemics to bees, we may mention sparrows and swallows. Set traps near the lives, baited with dead bees; shoot the birds; and hang up a few of sueh birds as you kill, on trees near the stands. Perseveranee for a time in this will rid you of the annoyanee.

Bees,-Bees are amongst the most dangerous foes of their own kind, being bold and resolute plunderers. It is only weak stoeks, however, that suffer, so that union is the obvious eure. Aroid also plaeing your hives too elose together; and also avoid at any time plieing a weak stoek near a strong one.

BEE-FLOWERS.-Conspicuous among all the plants loved by bees (for the best of reasons, that they get the most honey or other substanees from them), are clover, wild-thyme, heath and broom, borage, Freneh buekwheat, and Melilotus leucuntha. This last may be usefully grown for the bees' espeeial gratifieatiou. It is easily enltivated, blooms from June to November, and is ornamental in addition to its other good qualities. But the most important qualifieation of bee-pasturage is, that there shall be always something for the bces, from the very carliest 
spring to the very latest autumn. It will be uscful, therefore, to append a list of bec-flowers.

Spring. - Erica carnea, * winter aconite, * rosemary,* laurustinus, hazel, * snow-drop, crocus, * willow, ${ }^{*}$ osier, * primsrose, hepatica, violet, almond, wallflower* (single), borage, * onion, gonseberry, apricot, peach, apple, gooseberry, * eurrant, * laurel, turnip, * cabbage, ctc., * strawberry, tulip, hawthorn, gorse or furze, columbine, laburnum, berberry,* ribes sanguineum, Dutch clover.*

Summer.-Syringa, heliantheinum, annual poppy, * sea-kale, French willow, sweet-brier, bean, yellow lupine, inignonette, ${ }^{*}$ blackberry, chestnut, mallow, lime, * hyssop, teazle, nasturtium, yellow vetch, sainfoin, broom, wheat, viper's bugloss, * raspberry, * symphora, racemosa.

Autumn.-Michaclmas daisy, winter savory, purple houseleck, ivy, honeysuckle, Frencl buckwheat* sowed at midsummer, Spanish broom, * hollyhock, * heath, ${ }^{*}$ sunflower, lemon thyme,* St. John's-wort, melilotus icueantha.*

Those marked with an asterisk are understood to be the flowers especially favored by the bees. What a choice little garden for himself, as well as for his bees, the apiarian may make from the-above list, if he does not choose to leave the bees dependent upon the stores of the neighborhood at large!

TRANSPORTING BEES.-Though few, in this country, it is presumed, will adopt the plan recommended in the following paragraphs, yet they are interesting as showing the pains taken elscwhere in the keeping of bees: "Should the surrounding ncighborhood not furnish a sufficiency of flowers, the practice of transportation, or shifting, is strongly recommended by many antliors. It is not in the power of every bee-keeper, but as those whose liome is placed by a river or canal, have a means at hand for transporting their hives, we liave cliosen to mention it here. In some countries, boats are built expressly for this purpose. They receive a very large number of hives in each boat, and by traveling for a few hours at night, the bees find themselves in a new country during their working hours, and the hives are rapidly filled with honey and wax of the best quality. The boatmen receive a small sum for each hive that they transport, but we rather fancy that their ingenuity does not rest until it lias extracted some portion of the honey from the bestfilled hives. The Nile is mucl used for this purpose, and bees traverse the entire length of Egypt during the summer. In China ducks are subjected to the same inigiatory life, and thrive amazingly. Hives inay easily be carried on inen's shoulders, as that mode of conveyanee shakes them less than carriage by wagon. Heatlss are the best places that bees can possibly live in, and in Scotland there are people who make their living by taking care of hives during the time that the heath is in blossom, a period of about two months, for which time a reut of from one shilling to cighteen pence is paid by the proprictor. It is always necessary while the bees are migrating, to take them at least ten miles during the nocturnal journey, as they are otherwise apt to fly back to the former position of their hive, and to lose themselves in scarching for it. The distance to which bees ean fly for food is shown in the following anecdote, whiel has been recently published: 
" A man who kept bees in Molborn, wishing to find out where they worked, sprinkled them all with a red powder as they eame out of the live in the morning. As the heath and thyme were now in full bloom, he at onee thought that Inampstead, being the nearest heath, would be the likeliest place to find his bees. As soon, therefore, as his bees were gone away, he hastened to the heiglits of Hampstead. The walk was a long and toilsome one, of at least four iniles, in a July sun. But he trudged manfully on, soon left behind him Camden and Kentish towns, and at last was refreshed with the soft summer brecze sweeping aeross the purple and golden bloom of the heath. After a few minutes' rest on the green sward, he began his seareh, and before long was delighted to find there, among thonsands of other busy bees, his own little fellows in the dnsty red eoats, whieh he had given them in the morning.' Many of the bees made the journey more than twiee in each day, thus piloting themselves through sixteen miles of smoke and dust within the twelve hours.

"If the hives are taken by water, they should always be plaeed on the shore at some distanee from the bank, before opening the doors, as they will very probably when returning home, wearied and laden with their burdens, fall into the water before they ean reach the hive. If the hives are plaeed for the season, they should be kept at some little distanee from other hives, as if they are weak, their more powerful neighbors will inevitably plunder them."

FUMIGATION. - The following partieular deseription of the manner of fumigating or stupefying bees will enable any one to praetiee it.

Fumigation implies direeting eertain snoke of a stupefying eharaeter into the hives, so as to render the bees harmless while their eombs are being removed, while at the same time no injury is done to the bees thernselves. There are several substanees which stupefy; tobaeeo is one, but it is apt to give the wax and honey an unpleasant flavor, and we will, therefore, say nothing about it. The best niaterial that ean be used for this purpose, is the lyeoperdon, or eomuon puff-ball. A fine specimen of this fungus will grow as large as a ehild's head. It may be found in almost any field where mushrooms grow. It should always be gathered when nearly ripe, in dry weather, and either exposed to the heat of the sun or plaeed in an oven until it turns brown and leathery. Some al ways sqneeze it flat during the drying proeess, as it then ean be packed easier, and appears to take fire sooner than if left to dry in any shape it ehooses to take. In order to insure its burning freely when lighted, some reeommend that when dried, it should be dipped in a very weak solution of saltpetre, and again dried. There are many ways of applying the smoke, but all are useless unless the fungns is retained outside the hive, and only the smoke permitted to enter, as the bees are sure to fall on the burning mass, and thus many will be killed or mained. Moreover, the operator ought to be able to regulate the amount of smoke poured into the hive. Mr. Cotton, the author of "My Bee-Book," managed it by having a tin box made to fit the mose of a pair of bellows, in which was plaeed a picee of lighted fungus about twiec the size of a hen's egg. There were two openings in the box, one to admit the nose of the bellows, and the other immediately opposite, from which the 
smoke poured. The box being fixed on the nose of the bellows, and the end being placed against the entranee of the hive, a few vigorous puffs soon fill the hive with the stupefying smoke, under whose effeets, after a brief buzz of indignant astonishment, the bees are heard falling as thick as hail, and in a few minutes all is still within.

In performing the work of fumigation, many failures have oceurred, from setting about the operation too hastily, or from the non-observanee of a few rules that ean be easily remembered, and as easily put in practice. In the first place, great eare must be taken that the smoke of the fungus or other material nsed for the purpose is not admitted into the hive at too high a temperatmre. If this is the ease, the heat of the smoke will in the first plaee seoreh and kill the bees, who will rush to the entranee of the hire on the first intrusion of the fumigating tube, and will also melt the wax of the combs, and do considerable misehief. The tube, therefore, should be a very long one, and small in diameter. There is no hurry about the operation, work the bellows quite deliberately; and the danger of burning the poor bees, or spoiling the combs, will be avoided. There is hardly a more pitiable sight than to find on turning up the hive a number of bees lying on the board, with seorehed and shriveled wings-a loss of no small importance, as you will want every bee to set to work immediately, to repair the devastations eominitted in the hive. Another mistake not unfrequently ocenrs in following $\mathrm{Mr}$. Cotton's direetions too literally. It is not sufficient to have the fumigating box made merely of tin, as will most eertainly be done if that order is sent to a tinman, for the leat of the ignited puff-ball will speedily melt the solder, and the whole apparatus will fall to pieees. A ease of this kind oecurred very reeently. The box and tube were made aceording to order, the elay prepared for stopping the entrance of the hive round the tube, the fungus was duly lighted, plaeed in the box, the bellows fitted, and then vigorously worked. Suddenly, while the operators were complacently puffing away at the bellows, and congratulating themselves on seeuring both honey and bees by this method, the box fell in pieces, the tube consequently was drawn out of the hive door, and out rushed the bees in a tumultuous state of indignation, thereby putting their would-be eaptors to an ignominious flight. So, lest you meet witll a similar misfortune, give partieular orders to lave the whole affair made fire-proof, and then you may proceed without the least danger. Of course this must all be done some hours after dark, or the bees who are already out will soon signify their dislike of finding intruders when they return to the hive. It is also necessary to be very quick in eutting ont the eombs, as the bees do not remain long in their state of torpor or intoxieation, and are quite ready on their revival to employ their stings. Always examine the eombs that are removed, to see if any bees are left in them, as not unfrequently, when they begin to find that they camnot overpower the vapor, they dive to the bottom of an empty eell, and sometimes are so protected by this preeantion, that they revive rather sooner than their less fortunate companions. The wax of the combs thus obtained is mueh whiter than if sulphur is used, and of course, will fetch a higher price in the market, besides being free from a slight tinge of sulphury flavor, which hangs about them for a long time. 
For fumigating, the cirenlar bellows, set in motion by a wineh, are mueh superior to the doublc bcllows, as a constant strcam of sinoke is introduccd into thic hive, instead of a scrics of puffs. Mr. Pettigrew reeommends (probably because they ean morc ccrtainly be obtained when wanted), cotton rags, tightly rolled up in the form of a eandlc, and applied in the samc way as the fungus. If so, it will be found advisablc to steep the rags in a solution of nitre, as otherwise they are very apt to go out before a sufficicncy of smoke lias issued from them. The solution, however, must be weak also, or it may do mischief instcad of good, for ignited nitre is apt to send forth sparks, espceially if it is urged on by a draught of air. It may be possible that ether or chloroform may answer better than either fungus or rags, but the expcriments do not yet appcar to have been suffieicntly numcrous to cnable ouc to speak with eonfidenee. At all erunts, although chloroform and cther may not supcrsede fungus and nitre in stupefying bees, the smoke of puff-ball threatens to supersede ehloroform and ether in their anresthetie power as applicd to human bcings. Wc are bound to observe that fumigation may not be altogcther so harmless as is supposed, and therefore should not be used without neeessity.

When, after applying the fumigating apparatus, as has been deseribed above, the stillness that reigns in the hive indieates that the becs are in a state of insensibility, the hive may then be turned up for any neeessary opcrations. If honey is wanted choose the side combs, so as not to interfcre with the brood in the eenter, and bc modcratc. Replaee the violated hive earefully, and the bees will soon recover from their state of partial intoxication, and set to work to repair thc ravages that have been madc in their storcs. Nor does fumigation injure the working powcr of the bces. Unlike the effeets of aleoholie eompounds, which when taken in an overdose, entirely prostrate the sufferer for some time, the smoke of the fungus eauses a vcry transicnt intoxiention, which in a few minutes passes away, and the bees appear rather refreshed than otherwise, after their involuntary debaneh.

DRIVING, - In the hands of a skillful operator, driving will often be found uscful, as it partly supersedes the neeessity of fumigation. By driving, the bee-1naster induees his winged auxiliaries to change thcir position, by working on thcir fcars instcad of stupcfying what brains they lave. The best method of driving bees will be found in the pages of Bevan, who appears to think very highly of the operation. "Toward the dusk of the evening, when the family will be all, or ncarly all at home, and no annoyanec be experienecd from stranger-bees, let the hive, or box, be raiscd gently from its floor-board, and supported on threc thin wedges; lct an assistant bc at hand, provided with a tobaceo-pipe, or the fumigating box and bellows, from one of which at the moment of raising thc hive, lct a fcw whiffs of tobacco smoke be blown into it all round, and a few more after it has been raised. This expedicnt will soon induee the becs to ascend and eongregatc at the upper part of the hivc. It is next to be invertcd stcadily on a small tub or pcek measure, puffed again, and then quickly and aeeurately surmounted by an einpty hive or box, as nearly of its own diametcr as possible. After securely elosing the two hives, by tying a eloth firmly round them above and 
below the junetion, so that not a bee may eseapc, it will be proper to place an enipty decoy hive upon the stand where the full hive stood, to amusc any straggling bees that inay have stayed out late, or that may eseape during the opcration. The eonjoined hives are then to be removed into a darkened room, in the manner already deseribed, when, if the hive be well peopled, and the weuther warm, by drumming at first gently, and then sinartly with the open hands or a couple of stieks on the outside of the hive, the becs will be so alarmed, that in a few minutcs they will have asecnded into the super. The ascent may always be aseertained by the humining noise attending it. The impulse thus eommunicated to the bees should be given in the direction of the consbs, and by no mcans upon those parts of the hive whieh are opposite to thcir sides, as it might separate them from their attachments."

"The exehange of habitation having been effeeted, the ulterior proeeedings must be regulated by the object in vicw. If it be wished to have possession of the full hive, it will be simply neecssary to leave the deeoy-live in its plaee, and after covering the honey-eombs with a cloth to prevent them from being scented, to carry the bees with their temporary abode toward their usual place of entranee, when, by spreading a cloth on the ground, or on a table, all the becs may be dislodged and made to fall upon it, by a smart stroke with the hands upon the top of the hivc, and if one side of the eloth be raised to the resting-board, the bees will gradually aseend, and rcoccupy their original station."

Driving is made nse of by the Persian villagers, whose hives are made in a cylindrical form, and built horizontally into the walls of their houses, the bees' entrance being outside the wall, and a movable door inside, the end of the hive projecting more than a foot into the room. When the villager wishes for some honcy, he drums smartly upon the end of the hive whieh projects into his room, which eauses the bees to withdraw to the other end. The cirenlar lid is then quickly opened, as many eombs as he wishes for cut out, and the lid elosed again.

No one should be without spare hives or boxes ready to be used when required, even if they do not at the outset fit up a eonıplete apparatus. Thus-

1. $\Lambda$ spare box or hive will be ready to reecive a swarm obtained iu the ordinary manner, with all its picturesque but inconvenient aecessorics: as, long watching to know the moment of swarming; long runnings, perliaps, to overtake the vagrant young colony, over hill and valley, brakc and brier, and amid interminable ear-splitting tumult, which the bees liave the bad taste, it is supposed, to like; and the racc often ending in seeing the whole clustcr safely deposited in a neighbor's apiary, who swears it went from his hive. If you wish to avoid all that kind of thing, do your best to give the bees no motive for sueh wanderings, and every eoneeivable reason to stay where they arc. Put a decoyhive ready, with a delieious picee of comb in it (an old hive, with its own eombs, will be still morc attraetive), and it is most likely the seouts sent out to explore will return with sueh a glowiug aeeount of the land of milk and honey they have discovered, that the swarm will be impatient to be off and take possession. This must, however, be done with great care, and the deeoy-hive not plaeed in the air too soon, as 
its seduetive stores will not only attraet the bees who are intended to be its legitimate oeeupants, but also wasps, hornets, and robber-bees of all deseriptions, so that the swarm will have to inaugurate their entranee by a battle.

2. Bees always will settle themselves as soon as possible after swarming, and if they have not already determined upon a new habitation, will fix themselves in the first place that they think will suit them. There are many instanees known of bees having swarmed unexpectedly, and after eseaping from their former owners, having inade their habitation in a hollow tree in a wood, or in the roof of some descrted hovel. There have been several instanees of bees ehoosing to make their nests in the roof or tower of a ehurch, and an instanee came very reeently under the writer's notiee. For several years the eongregation had been eonsiderably annoyed by the presence of bees during the serviee, but had made no particular endeavors to rid themselves of the plague. One summer, however, brought with it sueh an inerease of bees that it was deemed necessary to institute an inquiry; for the winged intruders eame in sueh numbers, and buzzed about so loudly, and frightened the juvenile portion of the eongregation to sueh a degree, that the serviee eould not proceed with any eomfort. After some search, a hole was diseovered in the roof of the ehureh, through which the bees were constantly passing. This was aecordingly stopped up, and the workmen retired, eongratulating themselves on getting rid of their winged enemies so easily. They were, however, quite mistaken, for the bees descended in undiminished numbers. The roof was again examined, and found to be in sueh bad repair, that the eolony of bees who had taken up their residenee between the roof and the leads had found numerous openings, which they had enlarged for their own purposes. How to ejeet this formidable band was now the subjeet of deep consultation. Sulphur-smoke would not answer, beeause it would soon pass out through the apertures in the roof, and besides, there was a very prevalent alarm lest the ehurch should be set on fire. At last a veteran apiarian was seut for from the next village. He immediately planted a ladder against the exterior wall, and examined the stones until he diseovered the entrance to the bees' habitation. It was a mere fissure between two stones, where some of the mortar had fallen out, and the remainder been extraeted by the bees for their own eonvenienee. After surveying the prospeet for some time, he declared that a stone must be taken out of the wall before the bees could be dislodged, and immediately began to loosen the stone which had already been partly deprived of its mortar. The bees, of eourse, were highly indiguant at sueh an assault, but the man eoolly proeecded with his work, not heeding their anger in the least. When the stone had been eompletely loosened, he laid by the crowbar, and deliberately pulled it out with his hands. Ont rushed a perfeet cloud of bees full in his face; but he quietly laid the stone down, and eontented himself with brushing them off his faee until he had made further investigations. All the spectators took to flight at the first appearanee of the enraged bees; but their imperturbable enemy remained quietly at his post, and after deseending the ladder pulled some eight or ten bees out of his hair, and remarked that they had not stung him so mueh as he expoeted. 
It turned out that the man was almost invulnerable to stings; and althougl several dozen stings or so were in his faee, they did not leave the slightest mark, and certainly did not appear to ineonvenience him in the very smallest degrec. He afterward in the same eool manner extraeted the greater part of the eombs, and the bees, taking the hint, speedily evacuatcd thic premises. Tlierc was but little honey, but abundance of black, worn-out combs, and plenty of young bees in every stage of advancement. It is said that if any onc is repeatedly stung by seorpions, the pain diminishes each time, and that at last the system is entirely uninjured by it. An English naturalist was bold enough to try the experiment upon himself, and found that after he had been stung four or five times the pain was eomparatively trifling. Pcrhaps the same may be the ease with regard to the bec-stings, and the old man just mentioned possibly owed his immmnity to his frequent experienee, as Mitliridates was said to have eompletely fortified himself against poisons, by gradually imbuing his system with them.

3. Adopting as a rule the nou-disturbance in any serions way of your stock-hive, so that honey and brood shall there at least flourish together, when you think it is full (a solid sound from the live, and a great longeontinued buzz from the bees in answer to a tap, is good evidence of that state), attach your side-box, open the communication, and make the bees enter and leave by the entranee to the side-box, whicl you will do by elosing up the entranee to the other at night when the bees are all at home. A little piece of eomb, fastened at the top of the sidebox, may be at onee a useful hint and a temptation to the bees. This box is to be kept solely for honey-eombs by ventilation, whieh prevents the queen from laying eggs in it. When the heat in the side-box is $70^{\circ}$, you slould admit air through the top by means of a piece of tin pierced with holes. A draft through the hive, from the entranee to the roof, now takes plaee. This must not be done until you see the bees have fairly passed the Rubicon, and have done and ventured too mueh to be inclined to retreat to the stock-hive. When the box is full, you ean take it away, and replace it emptied, or by another, or by opening a eommunieation to a similar side-box on the opposite side, as in Mr. Grant's hive. The bees in it will soon floek to the queen in the parent hive. This arrangement prevents swarming, or at least has a great tendeney to prevent it; as the bees have more room given to them just when they want it. It also raises the stoek itself to the highest state of prosperity, as only the surplus honey is taken away, and the brood is not interfered with.

4. But if you wish to have an inerease of stoek without the inconvenienee of natural swarming, you may easily do so by treating the side-box exactly the same as the ehief one-that is, by leaving it unventilated. Brood as well as honey will then be deposited in it, and you have only to wateh for a farorable opportunity of seeuring two stoeks. This sliould be a little before the natural period of swarming, of whieh the signs are, clustering on the ontside, aetivity and eommotion among the drones, inaetivity of the workers, portentous silenee in the hive in the day (during whieh the prudent bees are supposed to be filling their poekets with provisions for their journey), and a singular hum- 
ming noise at night, presumed to eome from the young queen-bees announcing their advent. But these warnings apply less to the first than to the subsequent swarms. However, there is a pretty good rule for effeetive aetion. As soon as you find the side-box is nearly full, wateh for an opportunity when the queen, with abont two-thirds of the bees of the eolony, is in the side-box, then eut off the eommunieation with, and remove, the parent hive three or four feet distant, and put an empty hive in its exaet position. The returning bees will flock into the side-box as before, and that hive is done with. As to the parent-hive, the nurse-bees will take every carc of the brood in it; in fact, they will be just as though a swarm with the queen had left them; and will proeced with due equanimity to supply her place in the approved way. This is the mode practieed with snceess by Mr. Grant, and may be varied aeeording to eireumstanees. For instanee, if the queen should not have been left in the side-box with the greater portion of the bees, and has, therefore, been remored with the parent hive, the rest must be in effeet the same, as regards the two hives; most of the bees then might leave the side-box and floek to the queen in the parent-hive; but if there be a brood in the side-box, it appears that the nurse-bees will not desert it, and, therefore, there are still two eommunities, and both well provided with all they require for a new start in life.

5. There is also praetieed, it is said with great profit, a more summary way of procecding to make an artifieial swarm, which eonsists in fumigating the bees, in order to divide them into two bodies as beforc. The period ehosen is from the beginning of May to the middle of July, and when there are as many bees on the board at the bottom as will fill a thirty-two (eight and a half inehes by six) sized flower-pot. To aseertain this, blow a little smoke into them and turn up the hive. Before commencing operations, plaee the hive intended for the new eolony on the stand, with a bit of eomb in its roof, and a stiek aeross the middle to aid in the support of the eombs. If you are short of hives, this one may be used instead of an additional empty hive in performing the operations about to be deseribed. But the bit of eomb may be somewhat in the way. The bees having been stupefied by the fumigation, the hive is turned up, its top rested on the ground, and an empty hive plaeed over it of exaetly the same shape (at the edges at least), and a eloth tied round the eirelo of junetion. Then tap or drum gently at the sides of the tivo hives for about ten minutes, in whieh time probably about two-thirds of the bees will have aseended into the upper hive. The queen, fortunately for the operation, is generally one of the first either to run away from or to eonfront the danger (we know not which it is) by aseending. If your hive have a glass window, as all should have, you can sec when about the right proportion have aseended; if not, you must guess with the aid above given of the knowledge of the ordinary duration of time oceupied. Now take off the top hive and reverse it also on the ground, while you make sure the queen is there, throwing, meanwhile, the eloth (that you have removed) over the exposed bottom of the parent hive. If the queen be there (and she is easily distinguishable) you have only to shake queen and bees into the prepared live on the board, and restore the parent eolony also to the ordinary resting-plaee, where the bees will soon rear 
a new queen for it. If the queen be not there, then repeat the process with the prepared hive, and so you will eateh her at last. You ean then returu the first bateh of bees tbat were removed either to the parent hive or to the prepared hive, by simply shaking tbem into the one which most needs them.

Old lives thus deprived of their queens, and made to rear new ones, involve another important advantage. In twenty-one days the elitire brood will be reared, no fresh brood having been deposited (through the absenee of an old queen), and the young queen not having begun to lay, which they do in about ten days alter they leave the ecli. Ifere, then, wbere the hives are heavy, say forty or more pounds in weight, is an opportnnity of removing the bees (by fumigation) into a new hive, and selling the eontents of the old one. The honey is thus earlier than usual in the market, and fetehes a higber priee. Weak swarms should invariably be joined either to stiong ones, or to each other, and as soon as possible after swarming. It is only a strong community that ean so suecessfnlly establish themselves before winter, as to be in no danger from its severity. This junetion may be performed by fumigation, and taking away one of the queens. $\mathcal{A}$ stoek withont a queen may by the same ineans be added to one that is more fortunate: and this applies even to the restoration of a swarm to its own parent hive if there be ample room in it.

We have said nothing of the plan of annually destroying the bees, for it is almost an insult to our readers to suppose they would approve of so senseless and unprofitable as well as eruel a practice. It is quite true that thus all the honey that is made in a season may be obtained at onee, just in the same way that all the wolden eggs of the goose in the fablewere to be obtained at onee. Ancl if this wholesile deprivation be desired, it is perfeetly obtainable without destroying the bees, by simply fumigating them, and removing them to another hive. And if you don't ehoose to feed the bees during the winter, let somebody else have them that will. It is possible, in a tivorable late season, they may not need any assistanee. At all events, let it be the golden maxim of bee management never to allow a single bee to be injured if you ean help it.

We elose our artiele upon bees with the quaint story of an o d English apiarian._- In or about the year 1717, one of my swarms settling among the elose-twisted branehes of some codling-trees, and not to be got into an hive witlıout more help, my maid-servant, hired into the family the Miehaelmas before, being in the garden, very offieionsly offered lier assistanee, so far as to hold the hive while I dislodged the bees, she being little apprehensive of what followed.

" Ilaving never been aequainted with bees, and likewise afraid, she put a linen eloth over her head and shoulders, eonelnding that would be a suffeient gnard, and seeure her from their swords. A few of the bees fell into the hive; some upon the gromm; bnt the main body of them upon the eloth which eovered her npper garments.

"No sooner had I taken the live out of her hands, but in a terrible fright and surprise, she eried out the bees were got under the covering, erowding up towards lier breast and face, which immediately put her 
into a trembling posturc. When I perceived the veil was of no further servicc, she at last gave me lcave to remove it. This done, a most affecting spectacle presented itself to the view of all the company, filling me with the decpest distress and concern, as I thought myself the unhappy instrument of drawing her into so great and imminent hazard of her life, which now so manifestly lay at stakc.

"It is not in my power to tell the confusion and distress of mind I was in, from the awful apprehensions it raised; and licr drcad and terror in such circumstances niay rcasonably be supposed to be much morc. Every moment she was at the point of retiring with all the bces about her. Vain thought! to escapc by flight. She might have left the place indecd, but could not the company, and the remely would have been much worse than the disease. Had she enraged them, all resistance had been vain, and nothing less than her life wonld have atoned for the offensc. And now to have had that life (in so much jeopardy) insured, what would I not have given.

"To prevent, thercfore, a flight which must havc bcen attended with so fatal a conscquence, I spared not to urge all the arguments I could think of, and used the most affectionate entreatics, begging her, witl all the earnestness in my power, to stand her ground, and kecp her present posture; in order to which, I gave encouragenent to hopc, in a little spacc, for a full discharge from her disagreeable companions; on the other hand, assuring her she had no other chance for her life. I was, through neccssity, constantly rcasoning with her, or else besceching and cncouraging her.

"I began to scarch arnong them for the quecn, now got in a great body upon her brcast, about her neck, and up to her chin. I presently saw her, and immediately seized her, taking her from the crowd, with some of the commons in company with her, and put them together into the hivc. IIerc I watched her for some time, and as I did not obscrve that she came out, I conccived an expcctation of seeing the wholc body quickly abandon their settlennent; but instead of that, I soon observed them, to my greatcr sorro w and surprise, gathering closer together without the lcast signal for departing. Upon this I immediately reflected, that cither thcre must be another sovereign, or that the same was returned. I directly commenced a sccond scarch, and in a short time, with a most agreeable surprisc, found a sccond or the same; shc strove, by cntcring further into the crowd, to escape me, which I was fully determined against; and apprehending her without any further ceremony, or the least apology, I reconducted her, with a grcat number of the populace, into the hivc. And now the melancholy scene began to change, and give way to one infinitcly more agrecuble and plcasant.

"The bccs, presently missing their queen, began to dislodge and repair to the hivc, crowding into it in multitudes, and in the greatest lutry imaginable. And in the spacc of two or three minutes the maid had not a single bee about her, neither had she so much as onc sting, a small number of which, would have quickly stopped her breath.

"How inexpressiblc the plcasure which succceled her past fears! What joy appeared in every countenance upon so signal a deliverance 1 and what mutnal congratulations werc heard I I ncver call to mind the 
wonderful eseape without a secret and very sensible pleasure. I hope never to see such another sight, though I triumph in this most noble stand and glorions victory."

HIVES AND BOXES.- Various improved hives and boxes have, from time to time, been invented and more or less used, giving greater or less satisfaetion; yet among them all, we regard $E$. W. Phelps's Combination IIive* as one of the best. It was first patented in 1852, and during the past year has been greatly improved. It is true that his hives are palented, and many are disposed to look with disfavor upon all patents. llowever, we are too mueh indebted to the proteetion afforded by our patent laws, for the many and important inventions in all the arts of life, to render any refutation neessary of the futile objeetion.

Fig. 1.

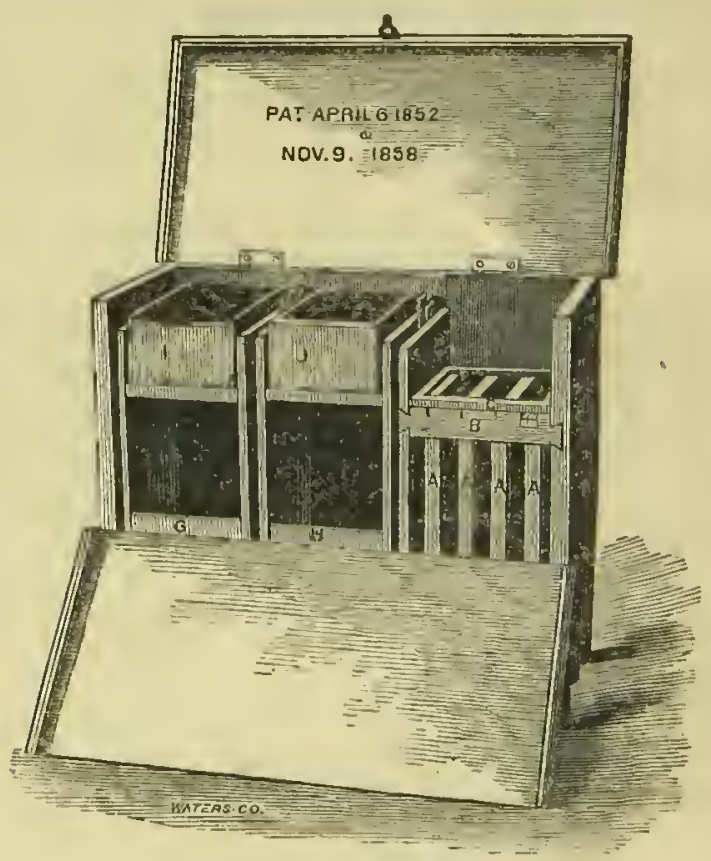

PHBLP'S COMHLNATION HIVE.

These hives are made in four different forms and styles, to suit the views and wants of persons in different locations and eirenmstanees, -the priees varying from $\$ 2.50$ to $\$ 15.00$. The latter is a "non-swarming hive," made with a mahogany or rosewood ease in imitation of a beautiful wash-stand, and intended to be set in a gentleman's oftice or dwelling. The others include swarming and dividing hives, in different

* These hives are manufactured at Elizabeth, New Jersey, where information concerning them can be obtained. 
styles and finish-some with boxes, others composed of "improved, movable, scctional frames," and others combining the two principlesusing a square box for the brood live and "sectional frames," and small honey boxes for obtaining the suplus honey.

We believe the following illustrations and descriptions of these hives will be acceptable to our readers.

Fig. 1 is a hive containing the two principles combined; with the top and back opened, showing the internal arrangement. The boxes $q$ and H, with the honey boxes I and $\mathbf{J}$ on the top, represent the "Combination Hive," patented 1852. That part occupied with the "Sectional Frames," AAAA is the late improvement of Mr. Phelps, also combining the two improvements, by using one box (H) for the brood-hive, with three or four of the frames, dAA, placed by the side (as seen in the engraving), with communications from the brood-hive to the frames, which are easily opened and elosed at will, by ineans of a thin slide between the apartments. The advantages secured by the use of the small frames, in the place of a large holley box, as formerly used, is, in obtaining the surplus honey in a much more desirable condition, either for family use, or for market: as it is stored in the sinall frames in separate pieces, five or six inches square, in which eondition it is taken from the hive without cutting or marring the combs, and can be kept in the frames until used.

The arrangement for freeing the honey and frames from the bees is a matter worthy of note, as all that is necessary to be done is, to elose the eommunication between the apartments with the slides, and insert a Jong tin exit tube in the front of the hive, so that the bees must pass out through the tube, from the apartments eontaining the honey-frames, and in returning to the hive, will enter the brood apartment throngh a more open space. In this way the bees are soon cleared from the honey, leaving it free for removal, without resorting to smoking, driving, etc.

The main brood-hive (H) is occupied by the bees as their permanent residence, and is about one foot square in the clear, in the hives as now made. It is divided into two equal parts, and joined at the center by means of small dowels of wire, so as to be separated at will. In each apartinent there is either a sectional frame, or guide bars, attached at the adjoining edges, in which the bees construct their combs, parallel with the separating joint, so that either half can be removed at will, withont cutting or marring the combs, while at the same time there is no partition in the hive to separate the eombs or bees; consequently, they construct their brood-combs equally in each half of the hive, and when either is removed, there is a certainty of obtaining about one half of the brood-combs - an advantage not secured in any other arrangement that has come under our notice.

The tops of these hives are so constructed that by means of a late improvement the bees cannot construct their combs across the frames or bars. This is a very important feature iu these hives, for, unless the combs are constructed straight on the frames or bars, and parallel with the joint of separation, the hive could not be taken apart without marring the combs and injuring the bees. It is also very important, in connection with the "movable frames," as here much difficulty has been experienced; 
and in ntumcrous instances the "movable frames," as construcled in other hives, have been rendercd entircly useless, as far as removing the combs is concerned, on account of the bces building thcir combs across them, fastening them all together. It will be observed, that while the bees are altogether in this "dividing-hive," the same as in any square boxhive, and oceupy the ccntral part with their brood-combs, as is their custom, either part can be removed at will to obtain a portion of the honey or the old brood combs; or, the colony may be divided, at the proper scason, and stocks multiplied without the trouble and risk attending swarming, whencver there is a sufficient quantity of bees to justify it.

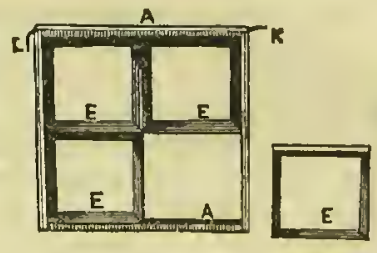

Fig. 2.

Fig. 8.

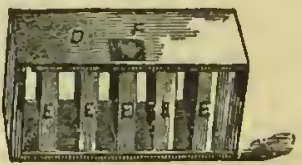

FIG. 4

Fig. 2 is a side view of one of the frames ( $\mathrm{A})$ taken out. Inside of this are four smaller frames (EEEE), cach one of which is about six inches square. The frame $\mathrm{A}$ is now dispensed witl, and a more simple and cheap manner is cmployed of connecting the "sectional frames" by means of small wire hooks, thereby saving the space occupied by the large frane, and the cxpense of making it.

Fig. 3 is one of the sectional frames taken out.

Fig. 4 shows several of the smaller frames EEE, arranged in a box to be placed on the top of the hive when desired. In operating with the bees, the frames can be removed, replaced, or shifted, as circumstances may require.

We think every practical bee-kcepcr will see at once the advantage secured by the nse of these small frames, over the large movable frame as constructcd by othcrs, for the honey taken from the hive, in the large frames, is in combs some twelve inches square, very inconvenient to bandle or take to market, while in the sinall frames, the honey is in the most beautiful and convenient form possible, to use in the family, or retail in market; being in scparate picces about five inches square, weighing from one to one and a half pounds per frame, in which condition it may be kcpt until required for use; and one comb used at a time, without moving others. He also manufacturcs a plain low-priced nonswarming hive, the case constructed the same as shown in the engraving, only longer and higher, to afford ample space for all the bees to labor and store honey in one apartment. The interior of this hive is composed entirely of "sectional frames," placed side by side and one above the other, three or four tiers high, to the number of one hundred or more of the small frames, with no partitions or divisions between them, whcre the bees all labor in a mass, storing the honey in the frames; when at the elose of the honey season it may be removed in the frames 
without moving the combs, or injury or exposure to the bees. This hive is so constructed, that, if desired, the becs may be confined to a space of one foot squarc, and the hive converted into a swarming hive.

The hives are all well ventilated at top and bottom, and the bottom being attached with butts and buttons, is casily let down and clcaned, without disturbing the bees. There is also a most ingenious and cffectual device for destroying the bee-moth, attached to the bottom of the hive, affording the moth or worms a most convenient harbor; or hidingplace in which they are sure to sccrete themsclves, when the trap can be withdrawn and the worms destroyed without opening the hive or disturbing the bees.

A "non-swarming hive," combining the forcgoing advaltages has long been sought for, as there are many persons who have never kept becs, that would gladly do so, if swarming and the trouble attending it could be avoided. And as the backs of these hives are g!ass, they afford a good opportunity to obscrve the operations of the bces without exposure to them. It is an interesting sight to observe a good populous colony of "busy bees" at their labors in the hive, during the season for gathering honey, and the pleasure is increased by the reflection that we are to share with them in the products of their labors.

Another important advantage which these hives possess over tlose in common use, is, that the tops arc composed of frames, or bars, on which the combs are attached, admitting a free circulation of air between all the combs, so that all the moisture and vapor, caused by the brcath and warmth of the bees escapes frecly up between them, keeping them dry and healthy, and free from mildew or mould; and it is strongly recoinmended to take off the honey boxes during winter, to give free ventilation, and prevent frost accumulating in the hive.

These hives are also well adapted to set in a building, on account of the peculiar construction of the entrance for the bees, and the alighting board, which forms a tubc or spout to conduct the bees through the side of the building, or out at a window of a dwelling, without admitting them into it, to interfere with any one. Many persons are using these hives in their dwellings and offices. In most instances they are made in imitation of an inclosed washstand, and can be opened and all the opcrations of the bees observed without danger from them, and the honey obtained in tumblers or glass jars, or, in the small frames, or boxes.

We also give a bricf description of Mr. Phelps's "bec-fceder." This is a very simple and practical arrangement for fecding becs; and as used in thesc hives obviates all danger of other bees robbing the colonics, or swarms, whilc being fed-a point of much importance, as generally, there is great danger of other becs being attracted to the hives by the scent of the fced, and, as it is the wcakest and smallest familics that usually require fecding, they are not able to defend themselves against the attacks of their more populous neighbors; and consequently, the robbers will enter the hives, and in a very short time, carry off all the honey it contains; and hence more injury than good has, in most cases, resulted from attempting to fced, for robbing one hivc, does not satisfy the burglar bees, but encourages them to attack the next feeble colony, 
and not unfrequently several stocks will thus be destroyed before their depredations ean be stopped.

This feeder is so construeted and arranged, and so'harmonizes with the construetion of the hives, that there is little or no danger to be apprehended from other bees being attracted to the hive or gaining aceess into it or to the feed, as the feeder is placed in the case, at the side of the brood-hive, near the top, with a small communieation into the feeder, near the top of the hive, and therefore the robbers must pass up amoug the bees and eombs through the body of the hive, to gain aeess to the feed. This they will not do, if the instruetions are followed, which are: "to nearly close the entrance tube while feeding, leaving a space of only half an inch or so, that only one or two bees ean enter at a time." In this eondition a few bees are able to defend themselves against all intruders.

Fro. 1.

Fia. 8.

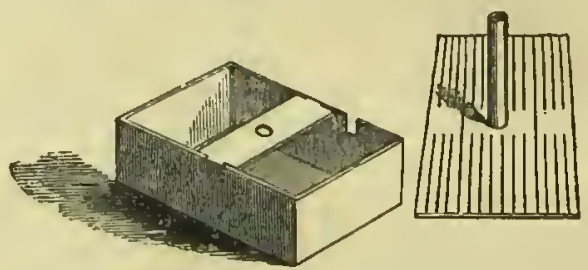

FEEDER AND FLOAT.

Fig 1 is a view of the feed-box. Fig 2, the float which is made to fit in it, to support the bees and prevent their becoming mired in the feed while feeding.

Fig. 1 eonsists of a wooden box made of half-ineh boards, and is ten or twelve inches long, six inches wide, and fonr and a half inehes deep, having one or two apertures an inch or so in diameter, near the upper elge, to eomnunieate with the hive while feeding. A square tin pan, two inehes deep, is made to fit elosely in the box, even with the bottom, and seeured there with small tacks.

The float, fig 2 , is made of thin slats of light wood, about ono ineh wide, and one eighth of au inch thiek, taeked on to a cross piece at the eenter, leaving a spaee between the slats of one eighth of an inch. The under side of the float is lined with strips of eork one eighth of an inch thiek, taeked to the wood. A loole, five-eighths in diameter, is made in the eenter of the float, and a tin tube fire inches long fitted in even on the under side. Another thin strip two inehes wide is fitted aeross the top of the box, with a hole in the eenter one eighth of an ineh larger than the tin tube, to reecive it; and on each side of this top strip, a pane of glass is fitted to confine the bees, and afford means to observe their operations while feeding. By uneans of the tin tube, the float ean be raised when the feed is put in the feeder, and the feed poured through it with a tmnnel. The float ean then be eased down on the feed, and the bees eome on to it and feed through the apertures between the slats without being mixed and drowned in the feed. It is surprising and also amusing, to see how eager they are to remove the feed and store it in 
the hive. An ordinary family of bees will frequently remove a pint of the feed in an hour, and usually from one to two quarts during a night; and it does not retard them in the least from gathering from the field on the following day.

The feed may be made of poor, uninerehantable honey, or honey and sugar mixed, and prepared with water. Southern honey also answers a very good purpose for feeding, merely to sustain the bees throngh the winter; or, when eleansed and mixed with erushed sugar, makes a very good artiele for the table, after being worked over and stored in the eombs by the bees. They also construet combs from the feed, as white and beautiful as any other. For feeding receipts see ante, page 285. 


\section{Household Menagerie and Museum,}

\section{Eumenclopedia \\ OR THE}

A BOOK THAT IS REALLY ALL LIPE-EVERY PAMILY SHOULD HAVE IT.

\section{LIVING NATURE IN ALL ITS FORMS.}

The only Book of its kind ever Published which gives Piotorial Ropresentations and

Popular Descriptions of the History, Habite, and Modes of Life,

OF ALL THE CLABSHS OF

\section{Living Beings on the Earth, in the Ocean, and}

$$
\text { THE AIR. }
$$

\section{ENGRAVINGS OF MEN AND ANIMALS.}

\section{In One Quarto Volume, 1350 Illustrations, Morocco, Gilt Back and Centre.-Price, $\$ 350$.}

Booka upon almost overy other subject have been clrculated among the peoplo, except those relating to the very interesting and important one of NATURAL Hrstory. Tho books wbicb have beretofore been published on this subject, have beon adapted either to mero children, or to tbose wbo make it a thorough study. Hence, very fow of the millions of readers in this country have within thelr rench auything satlsfactory upon this subject. Tbis Indicates a great and an obvious want, as no subject is uore intenseiy lnteresting, aud nonc more improving, tban tbat of tbe livlng beings that people the glohe. Tbis want we are confident we fully meet in the work we bere otfer to the public.

This subject is treated in a popular style; tecbnical names aud terms helng carefully oxcinded, thus adapting it to the understandings and tastea of goneral readers, and making it one of

\section{UW THE MOST INTERESTLNG AND USEFUL OF HOUSEHOLD BOOKS.}

\section{TT RMERACES}

I. All the Various Races of Men, with the varieties of each rnce, as the Enropean, Mongolinu, Malay, Negro. Indinu, Australlan, Negrillo, Telingin, Etbloplan, Hottentot, $\boldsymbol{A}$ byssiuinn, \&c., de., with Eingravings of oach.

II. All the Varieties of Land and Sea Animals, Including the varions onecies of Moukeys, the Llon, Tiger, Leopard, and all the anlmais of the cat-kind, Jackall, Wolf, Bear, \&c., dec, with thelr hahits and the modes of taking them by luntlng, trapping, onsnaring, dre., ant aiso the animals living botb in the sea and on tbe Land, and those living exclusively in the former.

III. All the Land and Sea Birds, a list too numerous to repeat, correct Engravings of whlch constitute a very attrnetive fenturo of tho work.

IV. All the Various Tribes of Fishes, of the Rivers, Lakes and Oceans.

V. The Reptiles of the Globe.

VI. The Various Insects, thelr hahits, nses and modes of destruotion, dc. dc.

VII. Sea Insects, or Crustacea.

VIII. The Shell Animals, or Mollusca, \&c, \&c.

All these various living heinga are described, aecurnte Illuatratlons of each, and thoir habits, uses and modes of life ato giveu; einlurucing over

THIRTEEN IIUNDIED ENGRAVINGS OF MEN AND ANIMALS.

No work wns over issued that is more attractlve to the young, none over whose pages thoy hong with deeper interest, or fion whlch more that is instructlve is derived.

$$
\text { It is the Book for the Young. }
$$

The Fapid Sale of over 12,000 Copies, shows tbo estlmntion in which it is held by the public and is at once an Index of tbe puhlic want and of the complete adaptatlon of tbis work to meet that want.

PUBLISILED BY THE AUBURN PUBLISHING COMPANY, AUBURN, $\mathrm{N} . \mathbf{Y}$.

SOLD OHLY TO SUBSCRIBERS: Is not tberefore for sale in any Bookstore, and can be had ouly of our Canvassing Agents. And all who desire to engage in soliciting subscriptlons for tbe above valuablo work, wlll find immodiate and profitable enployment by addresslng

\section{E. G. STORKE, Publishing Agent,}


Sold only to Sabscribers, - Not for Sale in Book Stores.-No Library is complete without it. - It should be in every Family.

\title{
A MAGNIFICEN'T HISTORY,
}

\section{Geography and Biography of all Nations,}

\author{
COMPBIBING, IN A BINGLE FOBK,
}

THE HISTORY OF ALL NATIONS-THE GEOGRAPIY OF ALL COUNTRIES, AND TIE BIOGRAPHIES OF THE PROMINENT MEN OF ALL TIME.

700 Engravings Illustrate its Mistory, -200 Portraits its Biography,-and. 70 Maps its Geography.

1285 DOUBLE-COLUMN IMPERIAL OCTAVO PAGES, COSTING OVER $\$ 11,000$,

AND CONTAINING AS MUUCH MATTER AS

\section{TWENTY 12MO. VOLUMES OF ORDINARY SIZE:}

THE WORK EXTENDS FROX THE EARLIEST PERIOD TO THE PRESENT TIUE:

And In It the Histery of every Nation, Ancient and Modern, ls separately glven.

\section{By S. G. GOODIRICH, the Napoleon of the Pen,}

Author of "Recollections of a Lifetime," "P'eter Parley"s Tules, \&c., dc.

A. New Revised Edition, including the Prominent Events of the Current Year.

It ls bolioved that a UNIvEasal mstonY, suitable In form, extent and arrangoment, to the wants of the mass of American readers has never hefore been presented to tbe publle. For this reasen, ind in cempllance with numcreus suggestiens frem those entitlod to respect, the anthor bas undertaken the formidable task of supplylng one of a pepular clasacter, and for general use.

The work presents a separate and distinet history, and alse exhibits the present atnte of every Nation, Anelent and Medern, including the recent, revolutions in Europe, and for the purpose of showing how nations have acted upen or lnllueneed the destinles of ono another. GrNinaL VIEws aro glven, st suitable periods, presentlng the great mevement of mankind as one family. in its onward mareh from the pust to the prescnt, combIning A CYCLOILDIA OF IIISTOLY $A N D$ UNIVERSAL GAZETTEEI OF GEOGRAIII AND BIOGRAPIIY. With $a$ vlow to reader It mere valuable, especially in the Family Library, an amplo Chronologleal Table is fiven, with a full Index-contrining upwards of four thousand Ifistorical and Goographical

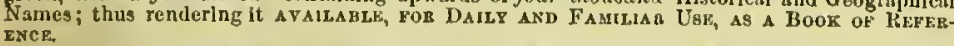

This work, by Mr. Goonatcr, mnat be very acceptable to the American publie It is the result of years of teil and labor, assisted in his rosenrelies by several scholars of knewn abllity. It bas been propared at a great expenso by tbo propriotors. No pains havo been spared in the erecntien of the

\section{ILLUSTRATIONS AND MAPS,}

which, were oxccuted expressly for tho work. Indeed all tbe other hlstorleal writings of Mr. Good aion slnk inte insignificance when compared with this, the result of his riper and naturor zears. It lo adulted that ONB IIUNDRED DOLIAIRS eould not purchase the same matter in sny other shape; and tho pubilshors confldently expect, in consideration of the grent literary valuo of tho work, tbe large sum expended in preparing it for the press, and the

EXCEEDINCLY MODERATE PRICE AT WIHCH IT IS OFFERED.

that it will be faverably received by every lover of gool books. Many of our first scholars, divines and gentlemon who have exanined the work, lave given it tholr UNQUALIFIED
APPROBATION.

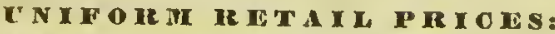

In 2 Vols, Moroces, gilt hacks and side dles, Marble Edges, ..\$8 00 Full Gilt bldes, and Gilt Edges, ................. 10 00

PUBLIBHED BY THE AUBURN PUBLISIING COMPANY, AUBURN, N. $Y$.

- Canvasing Agents franted for the abevo.

Address E. G. STORKE, Publishing Agent, AUBURN, N. Y. 


